\title{
MASTER
}

\section{A Moving Baseline for Evaluation of Advanced Coal-Extraction Systems}

Charles R. Bickerton

M. Dean Westerfield

April 15, 1981

Prepared for

U.S. Department of Energy

Through an agreement with

National Aeronautics and Space Administration

by

Jet Propulsion Laboratory

California Institute of Technology

Pasadena, California 


\section{DISCLAIMER}

This report was prepared as an account of work sponsored by an agency of the United States Government. Neither the United States Government nor any agency Thereof, nor any of their employees, makes any warranty, express or implied, or assumes any legal liability or responsibility for the accuracy, completeness, or usefulness of any information, apparatus, product, or process disclosed, or represents that its use would not infringe privately owned rights. Reference herein to any specific commercial product, process, or service by trade name, trademark, manufacturer, or otherwise does not necessarily constitute or imply its endorsement, recommendation, or favoring by the United States Government or any agency thereof. The views and opinions of authors expressed herein do not necessarily state or reflect those of the United States Government or any agency thereof. 


\section{DISCLAIMER}

Portions of this document may be illegible in electronic image products. Images are produced from the best available original document. 


\section{A Moving Baseline for Evaluation of Advanced Coal-Extraction Systems}

Charles R. Bickerton

M. Dean Westerfield

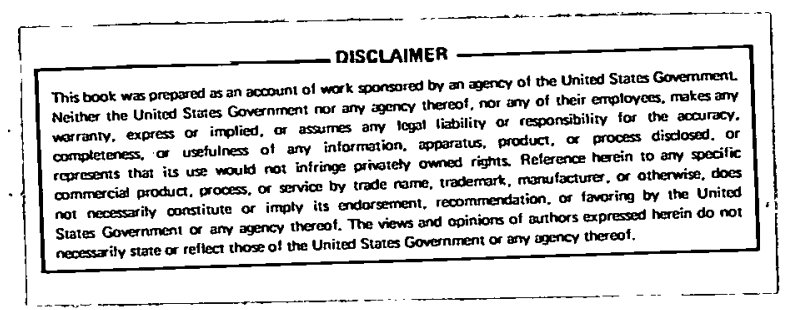

April 15, 1981

Prepared for

U.S. Department of Energy

Through an agreement with

National Aeronautics and Space Administration

by

Jet Propulsion Laboratory

California Institute of Technology

Pasadena, California 
Prepared by the Jet Propulsion Laboratory, California Institute of Technology, for the U.S. Department of Energy through an agreement with the National Aeronautics and Space Administration.

This report was prepared as an account of work sponsored by the United States Government. Neither the United States nor the United States Department of Energy, nor any of their employees, nor any of their contractors, subcontractors, or their employees, makes any warranty, express or implied, or assumes any legal liability or responsibility for the accuracy, completeness or usefulness of any information, apparatus, product or process disclosed, or represents that its use would not infringe privately owned rights. 
This document reports results from the initial effort to establish baseline economic performance comparators for a program whose intent is to define, develop, and demonstrate advanced systems suitable for coal resource extraction beyond the year 2000 . Systems used in this study were selected from contemporary coal mining technology and from conservative conjectures of year 2000 technology. The analysis was also based on a seam thickness of $6 \mathrm{ft}$. Therefore, the results are specific to the study systems and the selected seam thickness. To be more beneficial to the program, the effort should be extended to other seam thicknesses. 
This document is one of a series which describe systems level requirements for advanced underground coal mining equipment. These requirements are summarized in "Overall Requirements for an Advanced Underground Coal Extraction System,".JPL Publication 80-39 by Martin Goldsmith and Milton L. Lavin. Five areas of performance are discussed:

(1) Production cost.

(2) Miner safety.

(3) Miner health.

(4) Environmental impact.

(5) Recovery efficiency.

The report which follows presents details of a study which extrapolates contemporary coal mining technology to the year 2000 . The projections for cost and production capability comprise a so-called moving baseline which will be used to assess compliance with the systems requirement for production cost. Separate projections were prepared for room and pillar, longwall, and shortwall technology all operating under comparable sets of mining conditions.

This work is part of an effort to define and develop innovative coal extraction systems suitable for the significant resources remaining in the year 2000. Sponsorship is provided by the office of Coal Mining, United States Department of Energy via an interagency agreement with the National Aeronautics and Space Administration. William B. Schmidt, Director of the Office of Coal Mining, is the project officer. 
The funds expended for this study were provided by the Advanced Coal Extraction Systems Definition Project at the Jet Propulsion Laboratory, California Institute of Technology, Pasadena, California. The project is funded by the office of Coal Mining, U. S. Department of Energy via an interagency agreement with the National Aeronautics and Space Administration. William B. Schmidt, Director of the Office of Coal Mining, is the project officer for the Department of Energy.

The author would like to express appreciation for contributions and comments provided by members of the JPL staff. Guidance and comments received from Milton L. Lavin, project manager, are greatly appreciated. A special "thank-you" is extended to William B. Mabe for his input to the room-and-pillar analyses and his comments. Paul G. Gordon and Anthony Lynn are acknowledged for their thorough efforts directed toward the production of 1980 capital equipment costs. Other document reviewers are identified and individually praised: Frank A. Camilli, Jack Harris, and Martin Goldsmith. For her professional editorial assistance, Patricia A. South is freely applauded. Finally, I would like to personally thank Joan Winkler for her preparation of this document. 


\section{WAS INTENTIONALLY \\ LEFT BLANK}


II. SELECTION OF SYSTEMS

A. INTRODUCTION 2-1

B. BASELINE SYSTEMS $2-1$

C. EXTRAPOLATED SYSTEMS 2-3

1. Extrapolated Room-and-Pillar $2-4$

2. Extrapolated Longwal1 - 2-5

3. Extrapolated Shortwall

D. SUMMARY - 2-8

III. PRODUCTION ANALYSIS

A. INTRODUCTION - 3-1

B. APPROACH

C. ROOM-AND-PILLAR AND PANEL DEVELOPMENT SYSTEMS ----- 3-5

D. LONGWALL SYSTEMS -

E. SHORTWALL SYSTEMS - 3-12

F. COST ANALYSIS PRODUCTIVITY

IV. COST ANALYSIS

A. INTRODUCTION 4-1

B. PRODUCTION SIZING - 4-1

1. Mine Characteristics - 4-1

2. Financial Aspects - 4-5

C. MANPOWER - 4-5

D. EQUIPMENT AND CONSTRUCTION - 4-5

E. SUPPLIES AND MATERIALS - 4-6 


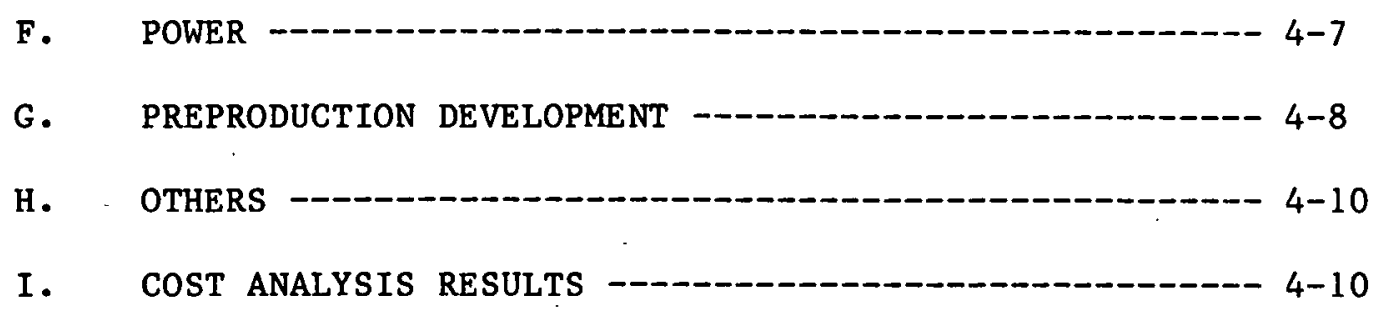

V. DISCUSSION OF RESULTS - 5-1

VI. REFERENCES -

VII. APPENDIXES
A. MINING CONDITIONS DESCRIPTIONS -
B. PRODUCTION ANALYSIS - B-1
C. COST ANALYSIS INPUTS -
D. COST UPDATE FACTORS - D-1
E. COST ANALYSIS RESULTS - E-1

\section{Figures.}

2-1 Underground Coal Production by Method -

3-1 Method Used to Obtain System Productivity for Cost Analysis -

3-2 Sequence of Face Operations for 1980

Shortwall Systems -

4-1 Information Flow Diagram for the NUS

Underground Mine Cost Model - 4-2

4-2 Idealized Mine Plan for Development Computations - 4-9

5-1 Production Cost per Clean Ton Versus Mining Conditions for Room-and-Pillar, Longwal1, and Shortwal1 - 5-3

B-1 Lift Sequence for 1980 Longwal1 and Shortwal1 Panel Development in Ideal Conditions -

B-2 Lift Sequence for $1980^{\prime}$ Longwall and Shortwal1 Panel Development in Average Conditions 
B-3 Lift. Sequence for 2000 Longwall and Shortwall

Panel Development in Ideal and Average

Conditions

B-4 Sequence of Steps for Shearer and Conveyor Movements During Removal of One Web With Half-face Operation -...- B-17

B-5 Plan-view Illustrations of Cycle Steps for 2000 Longwal1 Systems -

B-6 Gantt Chart of Shearer Scheduling for 2000

Longwall System in Ideal Conditions -

B-7 Gantt Chart of Shearer Scheduling for 2000

Longwa11 System in Average Conditions - -

B-8 Gantt Chart of Face Equipment Scheduling for

1980 Shortwall System in Ideal Conditions

B-9 Gantt Chart of Face Equipment Scheduling

for 1980 Shortwall system in Average

Conditions -

B-10 Gantt Chart of Face Equipment Scheduling

for 2000 Shortwall System in Ideal Conditions -.....- B-33

B-11 Gantt Chart of Face Equipment Scheduling for

2000 Shortwall System in Average Conditions - - - - B-36

B-12 Lift Sequence for 1980 Room-and-Pillar

Cases, Development B-39

B-13 Elemental Times Used in 1980 Room-and-Pillar Ideal Conditions Case to Determine Cycle Time for Development -

B-14 Lift Sequence for 1980 Room-and-Pillar Cases, Retreat - B-43

B-15 Elemental Times Used in 1980 Room-and-Pillar Ideal Conditions Case to Determine Cycle Time for Retreat -

B-16 Elemental Times Used in 1980 Room-and-Pillar Average Conditions Case to Determine Cycle Time for Development $B-47$

B-17 Elemental Times Used in 1980 Room-and-Pillar Average Conditions Case to Determine Cycle Time for Retreat 
B-18 Lift Sequence for 2000 Room-and-Pillar Cases,

Development - B-52

B-19 Lift Sequence for 2000 Room-and-Pillar Cases,

Retreat -

$\underline{\text { Tables }}$

2-1 Description of the Moving Baseline for

Room-and-Pillar, Longwall, and Shortwall -.--_-_-_-- 2-9

3-1 System Availability of Study Cases -

3-2 Mine Plan Parameters for Room-and-Pillar

and Panel Development - 3-5

3-3 Average Cut Cycle Time for Systems Partnered

with Continuous Haulage - 3-7

3-4 Average Cut Cycle Time for Systems Partnered

with Shuttle Car Haulage

3-5. Total Cycle Times for R\&P and Panel Development

Systems --_--_-_- 3-9

3-6 System Productivity for R\&P and Panel Development

Systems --

3-7 Total Cycle Time and System Productivity for

the Longwall Systems.-- 3-13

3-8 Total Cycle Time and System Productivity for

the Shortwall Systems -

3-9 System Productivity Results After

Consideration of Panel Moves - 3-16

4-1 Seam Recovery Factors for Study Cases -

4-2 Number of Machine Units Per Study Case -

4-3 Design Capacity of Study Cases

4-4 Salaried and Hourly Personnel Requirements

for Study Cases - 4-6

4-5 Machine Unit Costs in 1980 Dollars --

4-6 Estimated Power Cost per Clean Ton for

Studý Cases -

4-7 Production Cost per Clean Ton - 4-11 
The purpose of this study was to establish baseline economic performance comparators for the evaluation of new, advanced underground coal extraction system concepts. The baseline comparators consist of contemporary, 1980 systems that have evolved through time and will exist until a new concept has matured to a commercially acceptable form. The 1980 systems were projected to their conjectural states in the year 2000 by consideration of current research and development activities, trends in the industry, and present production constraints of the selected systems.

The technologies selected for study and their representative 1980 system components are as follows: ( 1 ) continuous room-and-pillar: rotary-drum continuous miner, shuttle cars, and dual-boom roof bolter; (2) retreat longwall: double-ended ranging shearer, armored face conveyor, and chock-type hydraulic roof supports; and (3) retreat shortwal1: rotary-drum continuous miner, mobile bridge carrier (MBC) conveyor haulage, and chock-type roof supports. The panel development systems selected for longwall and shortwall contain rotary-drum continuous miners, MBC units, and dual-boom roof bolters.

The proposed year 2000 system for room-and-pillar contained a rotary-drum continuous miner partnered with an MBC unit that automatically tracks the continuous miner. The roof control function of the system, which will permit breakthrough-to-breakthrough 1 ift lengths, will be accomplished with several hydraulically powered roof-support units and dual-boom roof bolters. This same equipment was used for panel development in the year 2000 longwall and shortwall cases.

The driving force for the year 2000 longwall system was better utilization of armored face conveyor capacity. Considering the present status of longwall R\&D activities, the fruition time for commercial products from these activities, and other production constraints, the proposed system has two double-ended ranging shearers equipped with vertical control systems. Complementing the shearers are roof supports, a high-capacity armored face conveyor, a stageloader, a face advancement control system, other ancillary components, and a master control system that effectively coordinates all face activities.

Because several experts have suggested narrower web widths for shortwall miners to improve ground control, the year 2000 system was configured with this notion. The shortwall system has a continuous miner with a 7-ft cut width, supports that achieve a 7-ft advance in one step, and a continuous haulage system that accommodates the face space limitations. In addition to possible strata control improvements, calculations showed that a narrower web system will increase shift production by $14 \%$ to $27 \%$. 
After identification of the systems, the performance parameters that determine shift production were identified and quantified. Two study cases were selected: ideal mining conditions and average mining conditions. The parametric values for the ideal cases were determined as the perceived design limits of equipment and operational procedures, not being influenced by the mine environment or operator ability. The values for the average cases were determined, in most instances, from actual operational data found in the literature and personal files. It was assumed that such values did not change over time for the selected systems. The following table presents the results of this study phase. The production of the 1980 cases was calculated as a check to the approach. The production range reflects the average and ideal conditions cases.

ESTIMATED SYSTEM PRODUCTIVITY IN RAW TONS PER MACHINE-SHIFT

\begin{tabular}{lcc}
\hline \multicolumn{1}{c}{ Rystem } & \multicolumn{2}{c}{ Raw Tons per Machine-Shift } \\
\hline Room-and-Pillar & 1980 & 2000 \\
$\begin{array}{l}\text { Longwal1 and Shortwal1 } \\
\text { Panel Development } \\
\text { Longwall }\end{array}$ & $290-680$ & $560-1540$ \\
Shortwal1 & $450-1330$ & $530-1390$ \\
\hline
\end{tabular}


The last phase of the study partnered the mining systems to appropriate mine plans so that discounted cash flow analyses could be performed. The analyses provided break-even production costs at a $15 \%$ return on investment. The following table shows the results in 1980 dollars. The range in values reflects the conditions cases.

ESTIMATED PRODUCTION COSTS

\begin{tabular}{lcc}
\hline \multicolumn{1}{c}{ Technology } & Production Cost per Clean Ton \\
\hline Room-and-Pillar & 1980 & 2000 \\
Longwal1 & $\$ 22.59-39.84$ & $\$ 15.71-26.66$ \\
Shortwall & $\$ 17.50-29.05$ & $\$ 16.48-25.71$ \\
\hline
\end{tabular}




\section{SECTION I}

\section{INTRODUCTION}

The purpose of this report is to establish economic performance measures against which the performance of advanced coal mining system concepts can be compared. The economic measures will be produced in the form of break-even production costs for a specified return on investment. Advanced systems refer to those which can extract significant coal resources that remain in the year 2000 and beyond, and which promise a significant improvement in economics and miner safety. Because the advanced system must compete with other underground mining systems that will exist at the time the concept has matured to its commercially acceptable design, the economic measures in this study will be developed for contemporary mining systems that have evolved over time. The projection of present systems to their conjectural states in the year 2000 will establish the moving baseline.

In order to attain the objective of this report, the scope of the study will contain several tasks. First, the baseline system will be selected and extrapolated to their year 2000 configurations. Therefore, there will be two sets of systems analyzed: present, 1980 systems and extrapolated, year 2000 systems. While the year 2000 systems will establish the economic measures for the advanced systems, the productivity and cost results of the 1980 systems will provide a. check on the analysis approach. The baseline systems will be contemporary representatives of three underground coal mining technologies: continuous room-and-pillar, longwall and shortwall. The projection of the baseline systems to the year 2000 will consider current research and development activities, industrial trends, and production constraints of the baseline systems.

Secondly, the performance parameters needed to determine system productivity will be identified and quantified. Raw tons of coal per machine-shift is the measure of system productivity selected for this study. The parameters used to compute productivity will be selected for two cases: ideal conditions and average conditions. The ideal condition cases will represent, in the author's viewpoint, the production potential of the systems, since the parameters will be derived as the perceived design limits of the equipment and operational procedures. Because the average condition parameters will be developed from actual operational data when available, the average condition cases will provide a realistic estimate of system productivity.

After productivity is established, each system will be partnered with an appropriate mine plan so that a discounted cash flow analysis can be performed in order to arrive at the break-even production cost per clean ton. The cost analysis will require the identification of mine size and life, personnel requirements, equipment and construction requirements, supplies and materials cost, power cost, and other inputs needed for a discounted cash flow analysis. 
The final section of the report will discuss the results of the study, both the system productivities and production costs. The 1980 results will be compared against current industrial experience and other studies to insure that reliable results have been produced. Finally, guidance will be provided regarding the use of the year 2000 results for comparisons.

This study was undertaken in support of the Advanced Coal Extraction Systems Definition Project at the Jet Propulsion Laboratory (JPL), Pasadena, California. The project is part of a program in the U.S. Department of Energy, whose purpose is to define, develop, demonstrate, and commercialize advanced coal extraction systems. The results of the moving baseline study will provide direct input to another document, in production at JPL, by Martin Goldsmith and Milton L. Lavin, entitled "Overa11 Requirements for an Advanced Underground Coal Extraction System." In this requirements document, JPL is trying to create a yardstick against which mining systems can be measured. To be considered as an advanced system, a concept will have to exceed in performance, against this yardstick, regardless of what existing systems or their logical derivations might offer. The standards by which a system will be judged, report to five separate attributes: (1) conservation of resources, (2) environmental effects, (3) miner health effects, (4) miner safety, and (5) production cost. Therefore, this moving baseline report will provide a standard of comparison for the production cost attribute.

Because mining regions and their mines vary greatly within the United States, it is unlikely that a universal system can be developed. Thus, the coal fields of Eastern Kentucky were selected as the initial resource target because they possess adequate coal reserves to support production well into the next century. Additionally, it is believed that markets for that coal will continue to exist; and the mining conditions pose a significant challenge to the system designer. Therefore, this study will endeavor, where possible, to be representative of Eastern Kentucky. 
SECTION II

SELECTION OF SYSTEMS

\section{A. INTRODUCTION}

Three contemporary underground coal mining technologies have been selected for extrapolation to the target year of 2000 . This section provides the reasons for the selection of the technologies and their representative systems, and for the transformation of the systems to their conjectural year 2000 configurations. The results of this section will be a description of the 1980 systems and their year 2000 counterparts, both of which comprise the moving baseline.

\section{B. BASELINE SYSTEMS}

Three of the technologies currently used by the underground coal mining industry are considered appropriate for this study. They are room-and-pillar with a continuous miner, longwall, and shortwall. Continuous room-and-pillar was selected because it accounts for over $60 \%$ of U.S. underground production today, and as Figure 2-1 shows, has made a rapid entry into the industry over the past years (Ref. 1). Although there are many possible system configurations, examination of equipment available for continuous room-and-pillar indicated that the most common scheme uses a rotary-drum continuous miner partnered with shuttle car haulage and supported by a dual-boom roof bolting machine (Ref. 2). Therefore, this system configuration was used as representative of the contemporary, 1980, case.

Longwal1, which is applicable to larger mines, was selected for several reasons. First, as shown in Figure $2-1$, longwall has had a consistent rate of growth in the industry. Additional1y, longwa 11 may account for a considerable portion ( $12 \%$ to $25 \%$ ) of underground production by 1985 (Refs. 3. and 4). If these projections are extended at the same rate to the year 2000 , longwall could contribute from $26 \%$ to $61 \%$ of underground production. Moreover, longwall mining systems account for the majority of underground coal production in many European countries. These factors suggest that longwall systems hold great promise for the U.S. coal industry. It has been reported that the most commonly used longwall configuration in the United States incorporates a double-drum shearer with an armored face conveyor and chock-type hydraulic roof supports (see Ref. 4). This system is chosen to represent the contemporary, 1980, case.

For longwall panel development, the system selected contains a rotary-drum continuous miner and a mobile bridge carrier (MBC) haulage unit. The system is basically room-and-pillar technology applied to panel development. The MBC unit was selected because it provides better haulage service to the continuous miner than shuttle cars, thus affording a higher potential productivity. At this time, the MBC unit is second only to the shuttle car in utilization and is increasing in popularity. Thus, it was thought appropriate to team this unit with 


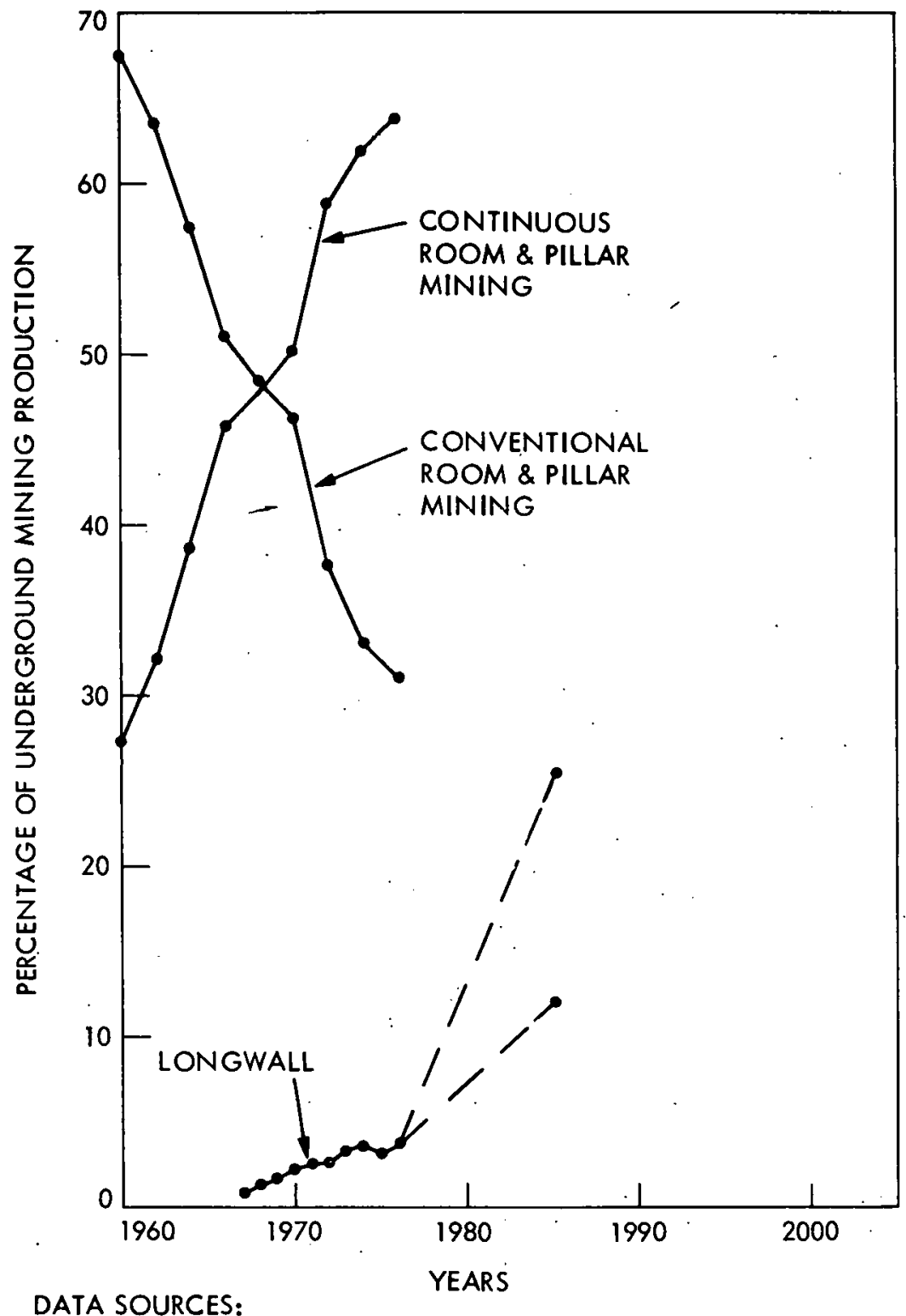

DATA SOURCES:

1960 - 1976: NATIONAL COAL ASSOCIATION, COAL FACTS, 1978 - 1979

HIGH LONGWALL PROJECTION: BUSINESS WEEK (1978)

LOW LONG WALL PROJECTION: KUTI (1979)

Figure 2-1. Underground Coal Production by Method 
the longwall. This selection widened the spectrum of mining systems in the study, also.

Shortwall technology, while producing only a small fraction of the U.S. total production, is relatively new. Shortwall holds promise for the future because, as a wall-type system, it has several advantages over longwall and continuous room-and-pillar, under proper conditions. Shortwalls require less capital than longwalls, function better at shallow depths under massive roof stratum, and are more flexible for skirting undesirable geological and man-made situations (Ref. 5). Shortwall also has better health and safety features than both longwall and R\&P. The European and Australian mining establishments, too, have expressed considerable interest in the future application of shortwall technology (Ref. 6). The shortwall systems that have been tried in the United States (there have been about 11 of them) used a panel development unit in conjunction with chock-type roof supports for the shortwall system (Ref. 7). The author elected to use the same development unit for shortwall and longwall as a basis for projections. Thus, both development and production for shortwall contain a rotary-drum continuous miner and an MBC haulage unit.

Conventional room-and-pillar technology was not selected for scudy because it was felt that the technology has reached its maturity, and will not experience significant changes in the future. Evidence of the continuing sharp decline in conventional production, as shown in Figure 2-1, suggests that it may not be an important alternative in the future.

\section{EXTRAPOLATED SYSTEMS}

The projection of the contemporary systems to the year 2000 will emphasize three mining functions: coal winning, haulage, and roof support. While other mining functions have impact on system productivity, it was felt that the above-mentioned functions were most important. For all three technologies, it is anticipated that improvements will be made in dust control, gas control, equipment safety and equipment reliability. No consideration was given to improvements in equipment panel move techniques, which have a significant influence on the overall productivity of longwall and shortwall systems. Projections of the progress to be expected in each of the major technologies were based in part on a survey of current research and development activities (Ref. 8), Continuing review of published reports and journal articles, and contact with the responsible goverment agencies have provided supporting information.

In addition to determining the focus of research and development activities in the industry, several major production constraints for room-and-pil1ar, longwal1, and shortwall were identified. For room-and-pillar, two major constraints were identified: the frequency of continuous miner place-change and the intermittency of shuttle-car haulage service. The constraints associated with longwall concern the capacity of armored face conveyors and their utilization, and the advance rate of the supports. An analysis of the contemporary, 1980 
shortwall system identified the cutting width of the continuous miner and the mode of support advance as the major production constraints. The following paragraphs provide more detail about the constraints and the system modifications that might be expected to improve the situation in the future.

1. Extrapolated Room-and-Pillar

A statutory provision of the Federal Coal Mine Health and Safety Act of 1969 prohibits movement of personnel beyond the last permanent support unless adequate temporary support is provided. To comply with this provision, many mine operators elected to shorten continuous miner advance distances so that the locally positioned operator remained under permanent support. The advance distance is generally $18 \mathrm{ft}$ to $22 \mathrm{ft}$, depending on the machine design. This option leads to the first production constraint mentioned for R\&P, the frequency of continuous miner place-change. Several equipment manufacturers developed devices for remote-control operation, and also developed locally controlled miner-bolter machines that permit permanent support placement in conjunction with entry advancement. Both manufacturers'. developments allow continuous miner advancement to approach the pre-1969 situation of breakthrough-to-breakthrough length 1 ifts (60 ft to $100 \mathrm{ft}$ )。 However, both have drawbacks. Remote-control operations are Iimited by operator vision, the position of haulage operators with respect to the last permanent support, the stability of the roof, and many others. Most miner-bolter machines experience roof-bolting delays that erode the potential time savings.

Another approach taken to improve the performance of R\&P systems is automation combined with remote-control. The U.S. Bureau of Mines had, and, more recently, the Department of Energy, has a program to develop an automated remote-controlled continuous mining system (Refs. $9,10,11$, and 12). The aim of the program is to develop a miner-bolter machine that can function without the aid of on-board operators. To date, the program has not demonstrated a fully automated system. Furthermore, a recent program demonstration of a locally controlled miner-bolter candidate met with many difficulties (see Ref。12).

An interesting approach taken by Frank Stafford, a retired mine superintendent, has increased production by $27 \%$ in initial tests (Ref. 13). The approach involves hydraulically activated roof support beams that are advanced with another set of hydraulic cylinders. This roof support system allows a locally controlled continuous miner to advance further by providing adequate temporary support. While the support unit is only in the initial development phase, it has great promise because it provides a very simple, straightforward solution to the roof control problem, and it can continue to be used with present equipment as it evolves.

The second RôP constraint, the intermittent service provided by shuttle cars, may be eliminated by use of a continuous haulage system, such as the mobile bridge carrier (MBC) unit manufactured by 
Long-Airdox Company. While there are several reasons why industry uses shuttle cars more extensively than MBC units, the major reasons concern surge capacity, maintainability, flexibility, and ease of operation (see Ref.2). Chain-conveyor MBC units now manufactured by Long-Airdox have a surge bin option for their customers (Ref. 14). Additionally, a conceptual study of an automated remote-controlled continuous room-and-pillar mining system placed a surge feeder unit between the continuous miner and MBC unit (Ref。15)。This system design is part of a long-term development program in the Department of Energy (see Ref. 11). Some components of the conceptual system are undergoing additional study. (Refs, 16 and 17). In order to improve the tracking and guidance of an MBC unit behind a continuous miner, the Department of Energy is developing an "auto-track" MBC unit (Ref. 18). With a feedback control system, the MBC unit will straddle and follow an induction cable that is laid on the mine bottom by the inby segment of the unit which is under local, manual control. This addition will ease guidance and control problems.

As the previous discussion indicates, there may be several future system options that directly address current R\&P constraints. However, for this moving baseline, a standard rotary-drum continuous miner, partnered with an automatically tracking $M B C$ unit, hydraulic temporary roof support units, and dual-boom roof bolters were selected. This system is seen as an obvious evolution of existing equipment that does not require a great deal of sophisticated hardware, and at the same time minimizes functional interactions between coal winning and strata control. This system will also be used for the year 2000 longwall and shortwall development cases.

\section{Extrapolated Longwa11}

As mentioned earlier, the constraints of longwall production are the capacity of armored face conveyors, the under-utilization of face conveyor capacity, and the advance rate of roof support units. While the capacity of armored face conveyors does limit system production, it is not altogether clear that any major advances in the near future will change the situation. Conveyor capacity is governed by the cross-sectional area of the conveyor pan and the speed of the conveyor chain. The cross-sectional area is presently constrained by the design of the roof supports and the shearer, and conveyor flexibility requirements. Therefore, increase of the conveyor cross-sectional area will require system redesign. How this redesign might be accomplished is not clear.

Present chain speeds are limited in order to minimize the wear rate of chain links and pan, and to maintain acceptable noise levels. While several attempts have been made to develop lubrication. systems, none seems acceptable (Ref. 19). The only feasible approach may be more abrasive-resistant materials for the links or friction-reducing liners for the conveyor pans. While it is certain that manufacturers and researchers are investigating this avenue, no positive results were found in the literature. It is evident that present conveyor capacities may be a major limiting factor for longwall production. 
Other researchers in their studies of future systems have reached this same conclusion ( $R e f s, 20$ and 21)。

Despite the limitation present conveyors impose on overall productivity, conveyor capacity is under-utilized. This apparently contradictory situation is due to present operational cycles for shearers which have a considerable amount of nonproductive time. This point is illustrated by the analysis of the half-face method (Appendix B), currently, the most comonly used in the United States. The nonproductive segments of the shearer cycle for the two cases examined, ranged from $30 \%$ to $47 \%$ of the total cycle time. To improve conveyor utilization, two shearers (or more) could be placed on the face. This practice is quite comon in the United Kingdom (Ref, 22). Each shearer would be assigned to a particular segment of the face. With the use of an interactive control system, each shearer would cut its segment of the face in such a way that the conveyor is not overloaded and collision is avoided. Analysis of this configuration (Appendix B) showed a $33 \%$ decrease in the cycle time while obtaining the same production per cycle as the one-shearer scheme, thus improving total productivity. Although the two-shearer approach does not comply with MSHA regulation concerning one cutting machine per split of fresh air, the use of environmental sensors in the face area should permit the issuance of a regulatory variance.

Other studies examined the production increase that would result from modifications to the winning element only, such as wider-web shearers, and not to improving overall system efficiency as was done in this study (Refs, 20 and 23)。Furthermore, these studies were directed primariiy to respirable dust generation and methane liberation; they did not provide the overall system evaluation that is required for this analysis.

The present approach to automated longwall may improve the health and safety aspects of longwall systems by removing workers from critical areas, but may not necessarily improve production. During the preliminary design of an automated longwall (ALW) system that used a single shearer configuration, DOE contractors found that conveyor capacity constrained production (see Ref。21). However, present automated longwall. activities will definitely benefit future dual-shearer operations. The automated longwall program has identified three basic systems required for autonated, remote-controlled longwall mining: a vertical control system for the shearer, a face advancement system, and a master control system (see Ref。24). Efforts are underway to develop these systems for application to existing longwall configurations. Such developments will support the application of automation and remote-control to the dual-shearer longwall configuration, also. Additionally; British attempts at automated longwail 1 were partially successful, but encountered labor/maragement problems (Refo25). Their experiences, nevertheless, will benefit American developments. Therefore, the availabilicy of automated longwall options by the year 2000 does not seem unreasonable.

The third longwall production constraint is the advance rate of the roof support inits. The "state-of-the-art" cycle time for a support is about 3.0 seconds (Ref, 26). This value transforms into a 
support advance rate along the face of $30 \mathrm{ft} / \mathrm{min}$ because supports are normally on 5-ft centers. Therefore, the shearer travel rate along the face should be limited to $30 \mathrm{ft} / \mathrm{min}$.

Ideally, most roof support systems can be advanced along the face at a rate of $50 \mathrm{ft} / \mathrm{min}$ (Ref. 27). However, several factors 1 imit support advance rates: (1) movement of the face conveyor; (2) the loss of fluid pressure and fluid flow; (3) lowering the support from the. roof in preparation for advancement; and (4) raising the support to the roof after advancement. The first: factor led to the development of the "one-web-back" method of face advance. This method eliminates face advance delays caused by conveyor movement needs, improves roof control, and increases the available travel space between the conveyor and supports because roof supports are advanced immediately behind the shearer. Therefore, many American operators have adopted this technique.

The second factor, the loss of fluid pressure and fluid flow, is related to the inadequacy of hydraulic power pack capacity and the buildup of back pressure in the return line. These problems can be alleviated by increasing the capacity of the hydraulic system (see Ref. 27).

The last two factors, which are support movement-related, result from the design of longwall powered supports. Therefore, in order to improve upon the situation, the basic support design must be modified. The French Collieries Research Institute has under development a crawler sliding hydraulic roof support (Ref. 28). This support design permits advancement under load, thereby eliminating the vertical roofbeam movement required with conventional longwall support designs: It is not known whether the crawler sliding support is superior to the conventional support or is cost-effective, but there are several prototypes in the field (see Ref. 28).

As discussed, heretofore, there are ongoing activities that may produce solutions to several longwall production constraints. Considering the present status of these activities and the period of time involved, the following system.components are proposed for the extrapolated year 2000 longwall system:

(1) Two double-ended ranging drum shearers having vertical control systems.

(2) Chock-type roof support units.

(3) An armored face conveyor (AFC) with a peak capacity of 1500 tons per hour.

(4) A stageloader that can adequately handle peak loads from the AFC.

(5) A face advancement control system for the supports and AFC.

(6) A master control system that effectively coordinates all face activities. 


\section{Extrapolated Shortwal1}

As previously mentioned, the cutting width of continuous miners presently used in shortwall systems is usually $10 \mathrm{ft}$. Because of this width, the roof supports function in a manner which constricts production performance. These support constraints involve the rate of face advance and strata control.

Within the course of a face advance cycle, each support unit is moved forward twice, about $5 \mathrm{ft}$ each time. The first advance occurs as the continuous miner cuts along the face, and results in little, if any, production interference. The second advance does not start until the continuous miner finishes cutting and starts traming out of the face area. The resulting production interference is quite significant, accounting for $21 \%$ to $28 \%$ of the cycle time as shown in Appendix B.

Several shortwall operations have failed or have experienced many production delays because of poor roof conditions (see Refs. 7 and 18). While these poor conditions are mostly a result of natural processes, the unsupported roof area and quality of roof support that exists at the face do not help matters. While the continuous miner is cutting, the unsupported area is typically in the range of $400 \mathrm{sq} f t$ (40 ft $\times 10 \mathrm{ft})$. After the initial support advance, a span about $5 \mathrm{ft}$ wide along the entire face length (180 ft to $200 \mathrm{ft}$ ) is supported by the forepole devices of the supports. These devices provide little support resistance. This situation, along with the aforementioned roof span problem, promotes roof falis along the face. Roof falls not only delay production during their clean-up, but the resulting cavities also reduce support effectiveness and augment the problem.

Because the roof support constraints exist at the present cut widths, several experts have suggested narrower ones (see Refs. 5 and 6). Therefore, the extrapolated year 2000 shortwall system was projected to include this change. A review of in-house continuous miner specification pamphlets identified $7.75 \mathrm{ft}$ as the narrowest miner chassis width with the cutter head minimum at $8.5 \mathrm{ft}$. A discussion with an equipment designer led to the possibility of a narrower body and cutter head (Ref. 29). Therefore, a 7-ft wide cutter head was elected for the moving baseline. To complement this narrow continuous miner, a support was designed in-house to achieve a 7-ft. advance (Ref. 30). Additionally, it was assumed that a continuous haulage system could be designed to accomodate the space limitations. An analysis of this extrapolated system determined that shift production increases range from $14 \%$ to $27 \%$, depending upon the mining conditions.

D. SUMMARY

The moving baseline is summarized in Table $2-1$, where the equipment for the room-and-pillar, longwall, and shortwall systems is listed. 
Table 2-1. Description of the Moving Baseline for Room-and-Pillar, Longwall, and Shortwall

\begin{tabular}{|c|c|c|}
\hline System & 1980 & 2000 \\
\hline \multirow[t]{4}{*}{ Room-and-Pillar } & $\begin{array}{l}\text { Continuous miner } \\
\text { 20-ft lift length }\end{array}$ & $\begin{array}{l}\text { Continuous miner } \\
\text { Breakthrough length } \\
\text { lifts }\end{array}$ \\
\hline & Shuttle car haulage & $\begin{array}{l}\text { Mobile bridge carrier } \\
\text { haulage with automatic } \\
\text { tracking }\end{array}$ \\
\hline & Roof bolter & Roof bolter \\
\hline & & $\begin{array}{l}\text { Mobile, powered } \\
\text { temporary roof support } \\
\text { system (MTRS) }\end{array}$ \\
\hline \multirow{5}{*}{$\begin{array}{l}\text { Longwal1 and Shortwall } \\
\text { Development }\end{array}$} & Continuous miner & Continuous miner \\
\hline & $\begin{array}{l}20-\text { to } 40-\mathrm{ft} 1 \text { ift } \\
\text { lengths, }\end{array}$ & $\begin{array}{l}\text { Breakthrough length } \\
\text { lifts }\end{array}$ \\
\hline & $\begin{array}{l}\text { Mobile bridge carrier } \\
\text { haulage }\end{array}$ & $\begin{array}{l}\text { Mobile bridge carrier } \\
\text { haulage with automatic } \\
\text { tracking }\end{array}$ \\
\hline & Roof bolter & Roof bolter \\
\hline & & MTRS \\
\hline \multirow[t]{3}{*}{ Longwa 11} & $\begin{array}{l}\text { One double-ended } \\
\text { ranging shearer } \\
\text { (DERS) }\end{array}$ & $\begin{array}{l}\text { Two DERS's } \\
\text { AFC }\end{array}$ \\
\hline & $\begin{array}{l}\text { Armored face } \\
\text { conveyor (AFC) }\end{array}$ & Chock-type supports \\
\hline & Chock-type supports & $\begin{array}{l}\text { Automatic control of } \\
\text { DERS's, AFC, and supports }\end{array}$ \\
\hline \multirow[t]{3}{*}{ Shortwa 11} & $\begin{array}{l}\text { Continuous miner } \\
(10-\mathrm{ft} \text { head })\end{array}$ & $\begin{array}{l}\text { Continuous miner } \\
\text { ( } 7-f t \text { head) }\end{array}$ \\
\hline & $\begin{array}{l}\text { Mobile bridge carrier } \\
\text { haulage }\end{array}$ & Continuous haulage \\
\hline & Powered supports & $\begin{array}{l}\text { Powered supports } \\
\text { permitting one-step } \\
\text { advance }\end{array}$ \\
\hline
\end{tabular}


SECTION III

PRODUCTION ANALYSIS

\section{A. INTRODUCTION}

The next task is the identification and quantification of system performance parameters that dictate system productivity. The measure of productivity used in this study is raw tons of coal per machine-shift. The information used to quantify the necessary parameters comes from several sources: published literature, private communications, and the personal files and experience of the author.

\section{B . APPROACH}

The performance of any mining system may vary greatly over the range of mining conditions it encounters. In order to incorporate the effects of mining conditions into the analysis, it was decided to analyze all candidates in conjunction with two sets of mining conditions. These sets are designated as "ideal conditions" and "average conditions" throughout this report. In addition to the aforementioned reason, the two sets of mining conditions were selected for other reasons as well. These include the inability to accurately predict the effect of the mine environment on conceptual systems and the need to check the analysis approach against the industrial experience with contemporary underground coal mining systems. The results of the ideal conditions cases represent, in the author's viewpoint, the production potential of the systems within the constraints of the study. The performance parameters for the ideal cases were derived as the perceived design limits of the equipment and the operational procedures of the selected mining methods. In cases where actual operational data were used to develop ideal conditions parameters, the obvious effects of the mine environment were ignored. The results of the average conditions cases provided a means to check the accuracy of the analys is approach. Most of the performance parameter values of the average cases were derived from actual operational data. In other instances, the average conditions values were estimates based on the experience of the author and on the ideal values.

A "bottom-up" approach was selected for the production analysis. That is, the approach identified the basic cycles that dictate system productivity and arranged them into their hierarchical ranks. Figure 3-1 illustrates the process used to manipulate the system performance parameters within the various cycles in order to arrive at a system productivity value. Such an approach was chosen because it permits estimation of productivity for system configurations that are not currently in use by examining the performance of the system functions that control production. Additionally, the bottom-up analysis will be used to estimate the 


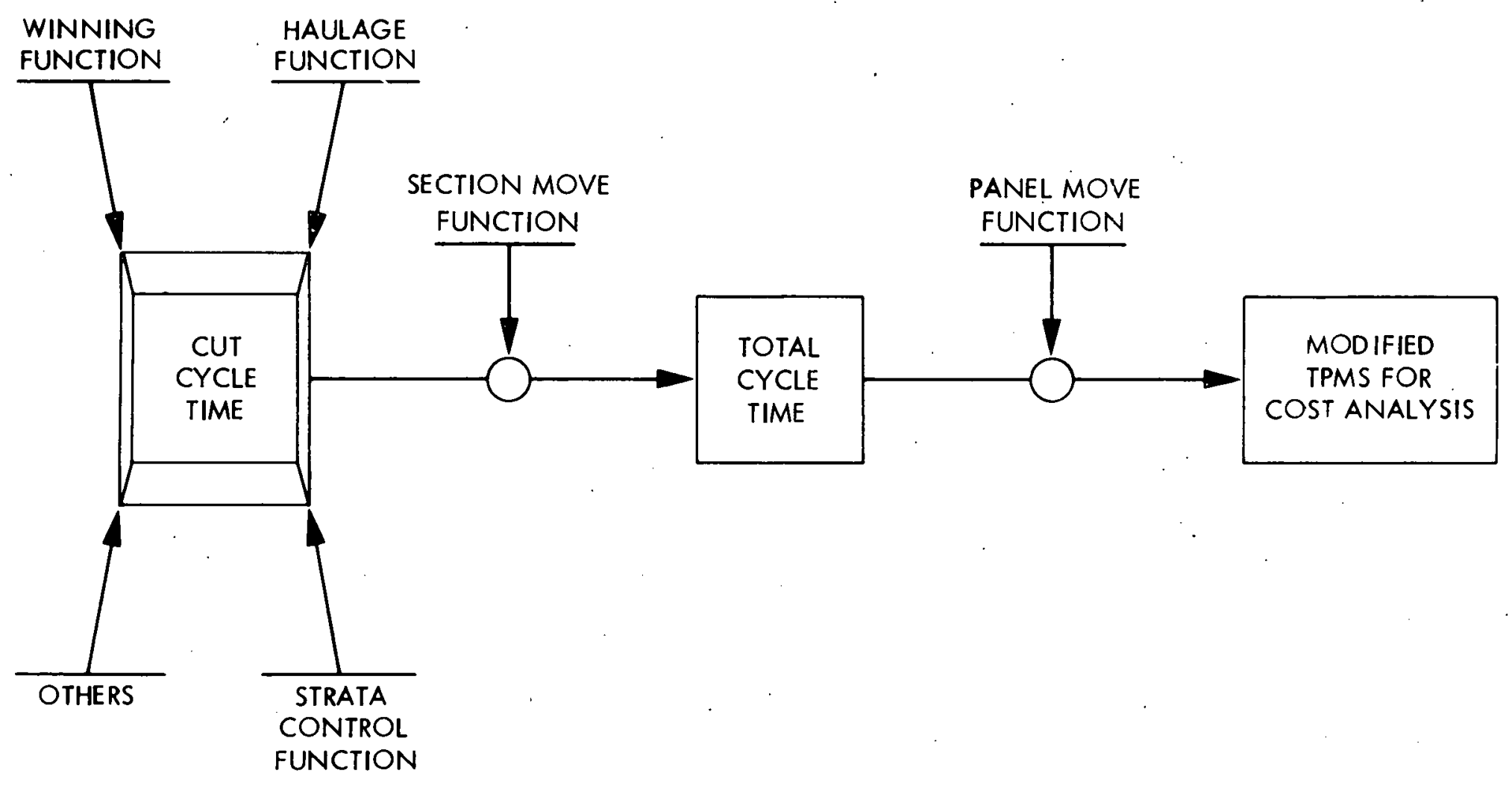

Figure 3-i. Method Used to Obtain System. Productivity for Cost Analysis 
production potential of new, conceptual systems. The cycles that were primarily used in this study involved the coal winning function, the section move (advance and retract) function, and the pant 1 move function. The influence of other functions, particularly, face haulage and strata control, was considered in the appropriate cycle.

Calculation of system productivity in terms of raw tons per machine-shift (TPMS) required the quantification of the four terms in the following equation:

$$
\mathrm{TPMS}=\frac{\mathrm{APT} \cdot \mathrm{A} \cdot \mathrm{T}}{\mathrm{C}}
$$

where $\quad \begin{aligned} & \text { APT } \\ & \mathrm{A}\end{aligned} \quad$ system availability
$\mathrm{T}=$ raw tons per cycle
$\mathrm{C} \quad$ total cycle time

The term APT is defined as that portion of shift time available for productive work. In this study, APT is equal to the difference between total shift time and the assumed inherent delays such as travel time and lunch. For all cases in the study, APT is $357 \mathrm{~min}$ per machine-shift. Further details are provided in Appendix B.

System availability, that is $A_{\text {, }}$ is defined as the quotient of net work time (NWT) divided by APT, where NWT is the difference between APT and other delays. To distinguish between the two conditions cases, the definition of "other delays" was varied, For average conditions, other delays referred to maintenance time, unexpected operational delays, human-related delays, and mine-environment-related delays. The mine-environment-related delays were subtracted from the "other delays" determined for the average conditions cases, and the remaining delay time was used to arrive at a NWT for the ideal conditions cases. The values for system availability are shown in Table 3-1. These values were assumed to be constant between the 1980 and 2000 cases. In most instances, the values for NWT and APT were developed from actual operational data of systems with equipment similar to the 1980 cases (Refs. 31,32 and 33). Further details concerning availability cam be found in Appendix $B$.

The remaining two variables, $T$ and $C$, are addressed in the following segments of this section, but a few explanatory comments are merited here. The variable $T$, raw tons per cycle, takes into account the volume of coal cut per cycle at a density of $851 \mathrm{~b} / \mathrm{ft}^{3}$. The dimensions of this volume for the room-and-pillar systems and the panel development systems are the lift (cut) length, the entry width, and seam height. For longwall, the dimensions refer to the face length, the web width, and seam height. Shortwall dimensions include the face length, the width of the miner's curting head, and the seam height . 
Table 3-1. System Availability of Study Cases

System Availability

Syștem Average Conditions Ideal Conditions

Continuous Mining

$\begin{array}{lll}\text { Machine } & 0.50 & 0.63\end{array}$

$\begin{array}{lll}\text { Longwa11. } & 0.56 & 0.64\end{array}$

$\begin{array}{lll}\text { Shortwal1 } & 0.60 & 0.66\end{array}$

Total cycle time, $\mathrm{C}$, is developed through the proper combination of specific coal winning machine parameters and the selected operational procedure of the entire machine unit, as detailed explicitly in Appendix B. For systems that have a continuous miner, partnered with shuttle car haulage, the combination involves the winning machine parameters, the mode of 1 ift (cut) removal, the cut sequence, the haulage machine parameters, the interaction of the haulage machines with one another, and the section move function. The computation of total cycle time for the longwall systems requires the combination of shearer parameters with the half-face method of operation and the section move function. Shortwall calculations combine continuous miner parameters with those of the supports, the guide rail, and the section move function to determine total cycle time. Because the year 2000 room-and-pillar systems and all panel development systems contain continuous haulage instead of shuttle car haulage, their total cycle time computations are more straight forward than the shutile car systems. Combination of the continuous miner parameters with the mode of 1 ift removal, the cut sequence, and the section move function provides the desired result.

The following three segments of this section, "Room-and-Pillar and Panel Development Systems," "Longwall Systems," and "Shortwall Systems, "discuss the highlights of the procedures used to determine total cycle time for each system. Each segment also identifies the "pre-pane1-move" productivity for the systems as calculated in Appendix B.

The final segment, "Cost Analysis Productivity, establishes the duration of the panel move function for each system and identifies the modified system productivities which account for idle time caused by this function. These modified productivities will be then used in the cost analysis. 


\section{ROOM-AND-PILLAR AND PANEL DEVELOPMENT SYSTEMS}

These systems are grouped together because they contain continuous mining machines (CMM) and all are derived from room-and-pillar technology. In order to estimate the productivity for these systems, appropriate mine plans had to be established so that the remaining variables of Equation 1 could be numerically defined. This effort involved the selection of several parameters: number of entries, centerline dimensions for entries and crosscuts, crosscut angle, cut sequence, and section ventilation scheme. Information contained in a.U.S. Bureau of Mines document provided input to the establishment of the parametric values (see Ref. 15). The details of the mine plan parameters are 1 isted in Table 3-2.

Table 3-2. Mine Plan Parameters for Room-and-Pillar and Panel Development

\section{Parameters}

$\begin{array}{lllll} & & \text { Entry and } & \\ \text { No. of } & \text { Crosscut } & \text { Crosscut } & \text { Cut Sequence and } \\ \text { System } & \text { Entries } & \text { Centerline } & \text { Angle } & \text { Ventilation Scheme }\end{array}$

$\begin{array}{ccccl}\begin{array}{c}\text { Room-and-Pillar: } \\ 1980\end{array} & 5 & 100 / 100 & 90 & \begin{array}{l}\text { Refer to Figures } \\ \text { B-12 and B-14 }\end{array} \\ 2000 & 5 & 80 / 80 & 60 & \begin{array}{l}\text { Refer to Figures } \\ \text { B-18 and B-19 }\end{array}\end{array}$

Longwal1 and Shortwal1

Development:

1980

$3 \quad 80 / 80$

60

Refer to Figures

2000

$3 \quad 80 / 80$

60

$\mathrm{B}-1$ and $\mathrm{B}-2$

Refer to Figure

$\mathrm{B}-3$

In addition to the selection of the parameters in Table 3-2, a decision was needed on the retreat mining method for the room-andpillar cases. The partial extraction method is most common in Eastern Kentucky. Of 319, roof control plans from Eastern Kentucky reviewed in a recent study, partial extraction accounted for $76 \%$ (Ref. 34). Additionally, there has been a trend in the United States towards. partial extraction (see Ref. 5). Therefore, the partial extraction method was selected for this study (see Figures B-14 and B-19).

The next step in the analyses of the systems was the identification of the elements that contribute to the total cycle time. For the 1980 Room-and-Pillar Cases, these elements included the sump cycle time, "maneuver-in-cut" time, and place-change time of the 
continuous miner; the change-point times, travel times, wait-point times, and dump time of the shuttle cars; and section move (advance or retract) time. Because the remaining CMM systems, both 1980 and 2000 cases, have haulage units that provide continuous service to the continuous miner, only continuous miner elements and section move time were needed for their analyses.

In order to calculate the sump cycle time of the continuous miner, the sump and shear rates were needed. For the ideal conditions cases, discussions with an expert regarding continuous miner performance revealed the theoretical limiting values for these rates to be approximately 17 and $34 \mathrm{ft} / \mathrm{min}$, respectively (Ref. 61). Although this does not mean that this high performance can be achieved in practice in anything but the most fragile coals under excellent roof and floor conditions. The sump and shear rates for the average conditions cases were derived from actual operation data (Ref. 35). The averages for the studied systems were a sump rate of $5.66 \mathrm{ft} / \mathrm{min}$ and a shear rate of $10.50 \mathrm{ft} / \mathrm{min}$. These ideal and average values were used not only for the 1980 Room-and-Pillar Cases, but also for the 1980 Longwall and Shortwal1 Panel Development Cases. Because the level of effort did not permit further study concerning the history and future of these rates, the 1980 values were used for the 2000 cases, too. Further details on the application of these rates can be found in Appendix $B$.

The tram rate of the continuous miner and the travel distance required identification before the "maneuver-in-cut" time could be calculated. The tram rate under ideal conditions was assumed to be 60 $\mathrm{ft} / \mathrm{min}$ while the average rate was selected at $50 \%$ of the ideal rate or $30 \mathrm{ft} / \mathrm{min}$. The distance travelled by the continuous miner during the extraction of a lift depends on the length and width of the 1 ift, the width of continuous miner cutter head, and the mode of lift removal. While the width of the lift $(20 \mathrm{ft})$ and the width of the cutter head $(10 \mathrm{ft})$ remained constant for all CMM systems, the length of lift and mode of removal did not. Details concerning these two aspects can be found in the appropriate segments of Appendix B.

Place-change times for the continuous miner were governed by the tram rates and the place-change distances. In this study, an average place-change distance was established for each CMM system. Each cut sequence was followed from beginning to end in order to arrive at the total place-change travel distance. That value divided by the number of lifts in a prescribed distance of advance or retreat and combined with the aforementioned tram rates provided the average place-change time for each CMM system.

The combination of the sump cycle time, maneuver-in-cut time, the mode of lift removal, and the place-change time permitted the calculation of the average cut cycle time for the systems that use continuous haulage units. These average values are found in Table 3-3. The 1980 Room-and-Pillar cases, because they employ shuttle car haulage, required further consideration to account for the influence of face haulage on the average cut cycle time. 
Table 3-3. Average Cut Cycle Time for Systems Partnered with Continuous Haulage.

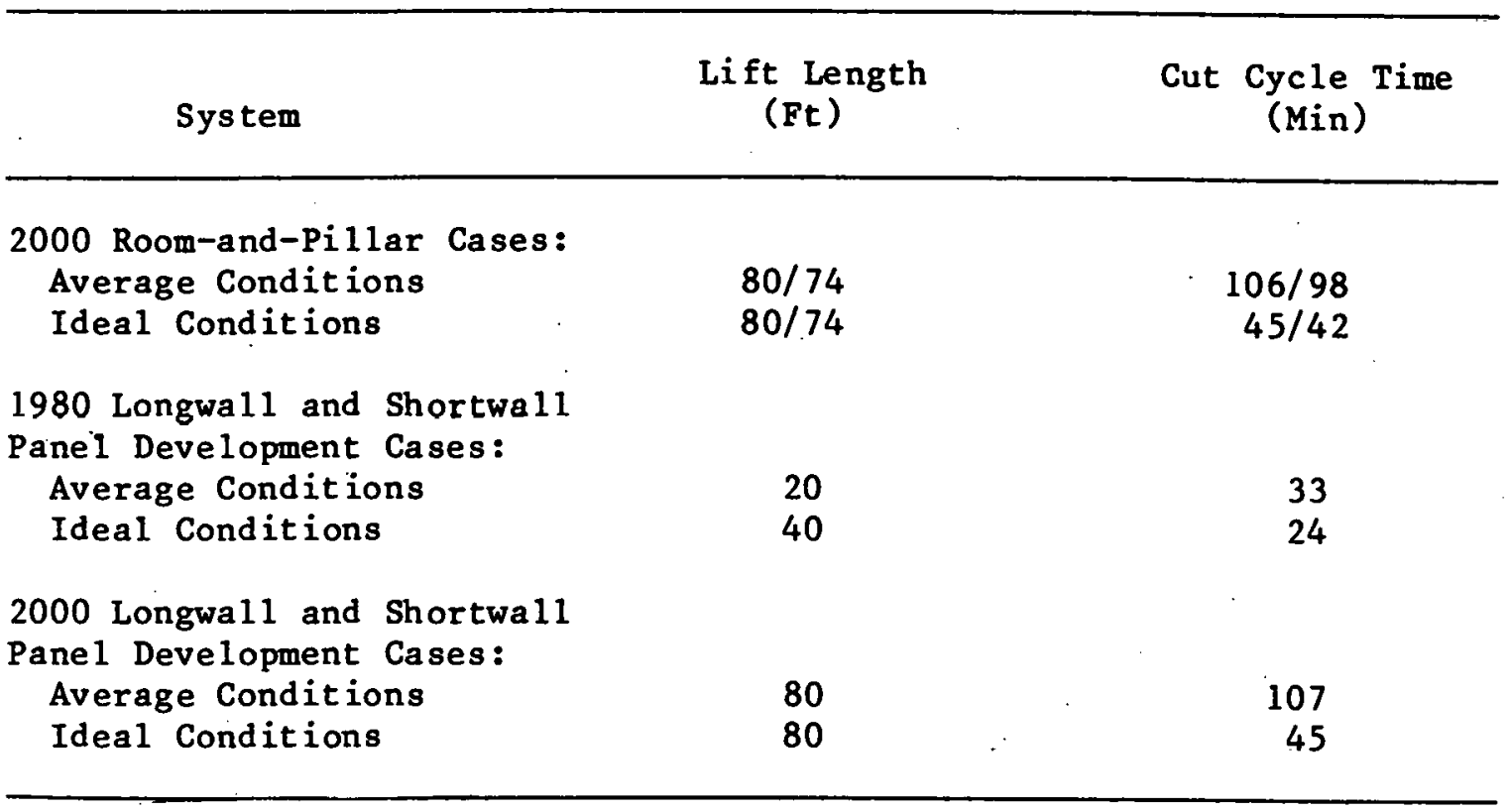

1. First number in category refers to panel development and second number refers to panel retreat.

NOTE: The differences between the lift length for panel development and panel retreat are caused by geometric characteristics of the mine plans. Also, lift lengths and cycle times are rounded to the nearest whole number.

As mentioned earlier in this section, there are several shuttle car elements that influence the performance of the 1980

Room-and-Pillar cases:, change-point time, travel time, wait-point time, and dump time. In order to calculate the first three elements, the shuttle car tram rates and travel distances were required. A review of the literature and manufacturer specification pamphlets identified $420 \mathrm{ft} / \mathrm{min}$ ( $7 \mathrm{MPH}$ ) as the maximum empty tram rate (Refs. $35,36,37$, and 38 ). The selection of a loaded tram rate for ideal conditions depended upon the empty-to-loaded relationships found in the literature and the judgment of the author. A loaded tram rate value of $300 \mathrm{ft} / \mathrm{min}$ ( $5 \mathrm{MPH}$ ) was assumed. The average conditions values were assumed to be $50 \%$ of the ideal values $-210 \mathrm{ft} / \mathrm{min}$ empty and $150 \mathrm{ft} / \mathrm{min}$ loaded. The approach used in this study developed an average travel distance for each category of shuttle car movement. The average distances combined with the tram rates provided the necessary elements for analysis. Coupling the shuttle car elements with the appropriate winning function elements and an assumed dump time of $0.5 \mathrm{~min}$ produced an average cut cycle time for each 1980 
room-and-pillar case. Figures $\mathrm{B}-13, \mathrm{~B}-15, \mathrm{~B}-16$, and $\mathrm{B}-17$ identify the element values and show how they were combined to help establish the average cut cycle times presented in Table 3-4.

Table 3-4. Average Cut Cycle Time for Systems Partnered. with Shuttle Car Haulage

\begin{tabular}{ccc}
\hline & Cut Cycle Time (Min) \\
System & Development & Retreat \\
\hline 1980 Room-and-Pillar Cases: & & \\
Average conditions & 56 & 67 \\
Ideal conditions & 29 & 35 \\
\hline
\end{tabular}

All lifts are $20 \mathrm{ft}$ long. Values rounded to nearest whole number.

There are several models available that simulate room-and-pillar operations having shuttle car haulage, but the level of effort for this study did not permit their utilization. While the simulation models exercise the continuous miner and shuttle cars through all movements required to execute a selected cut sequence, it was felt that the chosen approach provided an acceptable substitute.

The last element to be identified and to be combined with the average cut cycle time to establish the total cycle time was the section move element. This element relates to section advance time during development and section retract time during retreat. For this study, it was assumed that advance and retract times were equal. A review of the literature provides a range for move time from $1 \mathrm{~h}$ to $1.5 \mathrm{~h}$ (Ref. 39). Therefore, move times were assumed to be $1 \mathrm{~h}$ for the ideal conditions cases and $1.5 \mathrm{~h}$ for the average cases. These values, divided by the number of cuts per move provided an amortized section move time. The resulting total cycle times for the CMM systems are displayed in Table 3-5.

With the estimates of the "total cycle time" completed, the next step was the calculation of system productivity in terms of raw tons per machine-shift. The results for each system are exhibited in Table 3-6. As seen in Table 3-6, there are dramatic differences in productivity between the average and ideal conditions sets. For the 1980 R\&P cases, this difference is caused by the variations in system availabilities; shuttle car travel times; section move times; and the maneuver times, cutting cycle times, and place-change times of the 
Table 3-5. Total Cycle Times for R\&P and Panel Development Systems

\begin{tabular}{lcc}
\hline System & $\begin{array}{c}\text { Lift Length } \\
\text { (Ft) }\end{array}$ & $\begin{array}{c}\text { Total Cycle Time } \\
\text { (Min) }\end{array}$ \\
\hline $\begin{array}{l}\text { 1980 Room-and-Pillar Cases: } \\
\text { Average conditions }\end{array}$ & $20 / 20$ & $58 / 70$ \\
Ideal conditions & $20 / 20$ & $30 / 37$ \\
2000 Room-and-Pillar Cases: & & $116 / 110$ \\
Average conditions & $80 / 74$ & $52 / 49$ \\
Ideal conditions & $80 / 74$ & 38 \\
1980 Longwall and Shortwa11 & & 30 \\
Panel Development Cases: & & \\
Average conditions & 20 & 125 \\
Ideal conditions & 40 & 57 \\
2000 Longwall and Shortwal1 & & \\
Panel Development Cases: & & \\
Average conditions & 80 & \\
Ideal conditions & 80 & \\
\hline
\end{tabular}

1. First number in category refers to panel development and second number refers to panel retreat. Values are rounded to the nearest whole number.

Table 3-6. System Productivity for R\&P and Panel Development Systems

\begin{tabular}{|c|c|c|c|c|}
\hline \multirow[b]{2}{*}{ System } & \multicolumn{2}{|c|}{ Raw Tons Per } & \multicolumn{2}{|c|}{ Machine-Shift } \\
\hline & Average & Conditions & Ideal & Conditions \\
\hline \multicolumn{5}{|l|}{1980 Room-and-Pillar: } \\
\hline Development & & 310 & & 750 \\
\hline Retreat & & 260 & & 630 \\
\hline \multicolumn{5}{|l|}{2000 Room-and-Pillar: } \\
\hline Development & & 590 & & 1670 \\
\hline Retreat & & 530 & & 1490 \\
\hline \multicolumn{5}{|l|}{1980 Longwall and Shortwall } \\
\hline Panel Development & & 460 & & 1440 \\
\hline \multicolumn{5}{|l|}{2000 Longwall and Shortwall } \\
\hline Panel Development & & 550 & & 1510 \\
\hline
\end{tabular}


continuous miner. With the change to continuous haulage units for the year 2000 R\&P cases, the productivity differences relate to system availability, continuous miner parameters, and section move time. Productivity differences for the panel development systems are caused by the same factors mentioned for the year 2000 R\&P cases. Additionally, the lift length variation between the 1980 pane 1 development systems ( $20 \mathrm{ft}$ for average conditions and $40 \mathrm{ft}$ for ideal conditions) indirectly created productivity differences.

Table 3-6 also shows a difference in productivity between development and retreat for the R\&P. cases. The variations in shuttle car travel distances and continuous miner place-change distances account for the productivity differences for the 1980 cases. The year 2000 situations are caused by the different lift lengths (Table 3-5), attributed to a geometrical effect.

The changes in productivities between 1980 and year 2000 for the systems represented in Table 3-6 occur for several reasons. The R\&P change results from replacement of shuttle car haulage with continuous conveyor haulage, thus eliminating shuttle car change-out wait times. Additionally, the year 2000 R\&P cases, because their lift lengths are $80 \mathrm{ft}$ as opposed to $20 \mathrm{ft}$ for the 1980 cases, experience less continuous miner place-change time. The productivity boosts associated with the year 2000 longwall and shortwall development systems relate to less place-change $\varepsilon$ ime, also.

The last aspect of Table 3-6 which requires explanation is the productivity difference between the R\&P and panel development systems. In 1980, the selection of shuttle car haulage for the R\&P systems and continuous haulage for longwall and shortwall development largely produced the productivity variance. However, the $100 \mathrm{ft}$ entry centerline dimension and five-entry plan for $R \& P$ and the $80 \mathrm{ft}$ dimension and three-entry plan for panel development had some influence. These mine plan variations also caused the year 2000 productivity differences between $R \& P$ and panel development.

\section{LONGWALL SYSTEMS}

The quantification of total cycle rime for the longwall systems required the same basic approach as taken for the previous systems. A mine plan was selected to provide a panel length and face length. Also, a mode of face operation had to be selected from the several used by the American longwall establishment. From this point, appropriate performance paramerers had to be selected for the equipment discussed in Section II and for the mode of face operation.

For all longwall cases, a panel length of $3000 \mathrm{ft}$ was selected as being typical of American longwall practice (Ref. 40). A study to determine the optimal face length for longwall systems having a panel length of approximately the same measure as above (3024 ft) found, that little difference occurred with respect to return on investment for face lengths ranging from $200 \mathrm{ft}$ to $500 \mathrm{ft}$ (see Ref. 40). Therefore, a face length of $500 \mathrm{ft}$ was selected for the longwall cases. 
A review of the literature did not reveal much information concerning the most popular mode of face operation for a double-ended ranging shearer. However, a builetin distributed by the Joy Manufacturing Company announced the half-face operacion as being the most commonly practiced in the United States (Ref. 41). Additionally, halfface operation of a shearer is quite compatible with the "one-web-back" method of longwall face advance (Ref. 42). Finally, a recent article indicates that the half-face operation has better respirable dust characteristics than other modes of operation (Ref. 42). This factor alone is a plus for the half-face operation because respirable dust problems afflict many longwall installations (see $\operatorname{Refs.42}$ and 43). Therefore, such a mode was selected. Figure $B-4$ illustrates the steps of the operation, and the appropriate sections of Appendix $B$ discuss the half-face method in more depth.

The next step in the analyses of the longwall systems was the identification and quantification of system parameters that affect the shearer cutting cycle time. The predominant parameters include shearer haulage speeds, support advance rate, and armored face conveyor capacity. A study that produced a conceptual design of an automated longwall system suggested that shearer cut haulage speeds be limited to $30 \mathrm{ft} / \mathrm{min}$ so roof support advance could keep pace (see Ref. 26). Before this speed could be used, a check was made to insure that face conveyor capacity exceeded cutting capacity. In order to do this, the web depth of the shearer was required as well. as the maximum conveyor capacity. A web depth of 33 in. was found to be the present state-of-the-art and was used to determine cutting capacity (Ref.19)。 A review of available literature and personal commications identified $1500 \mathrm{TPH}$ (tons per hour) as the maximum available face conveyor capacity today (Ref, 44). Combination of cur speed, seam height, web depth and coal density identified a cutting capacicy that was several hundred tons per hour less than the conveyor capacity. Therefore, in the ideal conditions cases, a shearer cut haulage speed of $30 \mathrm{ft} / \mathrm{min}$ was used.

Other parameters required for cutting cycie time were shearer flit speed and turn-around times. Flit speed, being the rate at which a shearer cleans a completed web cut, was assumed to be $50 \mathrm{ft} / \mathrm{min}$ for the ideal cases because it was the maximum shearer haulage speed identified (see Ref. 21 and Ref. 45).

While the cut and flit speeds of the shearer in ideal conditions were perceived as design limitations, the speeds developed for the average conditions cases were the average of operational data available to the study (see $\operatorname{Ref}, 26$ and Ref。 46). The cut haulage speed was $11 \mathrm{ft} / \mathrm{min}$ and the $\mathrm{flit}$ speed was $28 \mathrm{ft} / \mathrm{min}$. These values corresponded well to recent information obtained during a mine visit by the author where the shearer cut speed was $15 \mathrm{ft} / \mathrm{min}$ and the $\mathrm{flit}$ speed was $25 \mathrm{ft} / \mathrm{min}$ (Ref. 47). Additionally, the conceptual design of an automated longwall suggested that a flit-to-cut ratio of $2: 1$ be maintained (see Ref. 26). Since the real data provide a ratio of $2.5: 1$, it was decided to use the average values. 
Turn-around elements refer to those activities on the longwall face related to directional changes in the shearer. For the half-face operation shown in Figure B-4, these elements include a cluster of activities at the tailgate and another cluster at the headgate. Tailgate activities encompass ranging of the shearer drums and reversal of the shearer and its loading devices. The time assumed for this element was $2.0 \mathrm{~min}$ ( see Ref. 46). At the headgate, the tailgate activities are experienced again with one addition. The cutting picks are checked and replaced as required. The time assumed for the headgare element was $7.0 \mathrm{~min}$ (see Ref。46). The headgate and tailgate turn-around elements were held constant for both conditions cases and for the 1980 and 2000 systems.

The combination of the shearer haulage speeds, the turn-around times, and the half-face operation provided the shearer cutting cycle

times. The addition of a section move element to the cutting cycle summed to a tocal cycle time. This section move element, referred to in Appendix $B$ as the amortized headgate move time, was quantified from actual operational data. For the ideal conditions cases, the smallest value found was used -0.50 min per ft of move (see Ref. 46). The average conditions value was taken as the average of all available data - 0.64 min per ft of move (see Ref. 46 and Ref. 48). These same values were used in both the 1980 and 2000 cases. Multiplication of the above values with the move distance (web depth) for each case produced the section move rimes.

The resulting total cycle times for the longwall cases, combined with the tons per cycle, available productive times, and system availabilities as per Equation 1 , produced the shift productions found in Table 3-7. More details are shown in Appendix B. The productivity variations found in Table 3-7 between the average and ideal conditions sets for each study year occur because of differences in shearer cut and flit speeds, availabilities, and section move times. The productivicy increases experienced by the year 2000 systems in relation to the 1980 systems were caused primarily by reduction of "dead time" in the cotal cycle times. For the year 2000 longwall case in ideal condirions, the Gantt Chart in Figure B- 6 shows how the cut travels of the headgate and tailgate shearers shadow most cycle deadtime (flit travel and turn-arounds). In the average conditions case for year 2000 longwall, the cut travels of the shearers totally dominate the total cycle time as shown in Figure B-7.

\section{E . SHORTWALL SYSTEMS}

As with the previous systems, the first step needed for the shortwall analyses was the selection of the mine plan: face length and panel length. Because there were no optimal face length studies found in the literature for the particular system configuration adopted here, typical lengths were deemed appropriate. Therefore, a face length of $180 \mathrm{ft}$ and a panel length of $3000 \mathrm{ft}$ were selected. 
Table 3-7. Total Cycle Time and System Productivity

for the Longwall Systems

System

Total Cycle Time

(Min)

System Productivity

(Raw tons per machine-shift)

1980 Longwa 11:

$\begin{array}{llr}\text { Average conditions } & 79 & 890 \\ \text { Ideal Conditions } & 38 & 2090\end{array}$

2000 Longwa 11:

Average Conditions

56

1350

Ideal Conditions

27

3250

NOTE: Total cycle times are rounded to the nearest whole number.

With the face length established, the total cycle time could be estimated. The parameters that required quantification include the cut and $f l i t$ rates of the continuous miner, the advance rates of both the supports and guide rail, and section move rate. The sequence of operations for the continuous miner, supports (chocks), and guide rail in the 1980 shortwall systems are shown in Figure 3-2. The cut rates of the continuous miners in the shortwall systems were dictated by the sump cycles established for the conditions cases in the preceding CMM systems reporting. Review of Appendix $B$ reveals these rates to be $0.23 \mathrm{~min}$ per $\mathrm{ft}$ for ideal conditions, and $0.57 \mathrm{~min}$ per $\mathrm{ft}$ for average conditions. The flit rate, or speed at which the continuous miner retreats from the face after finishing one pass, was reported to be 20 $\mathrm{ft} / \mathrm{min}$ in actual conditions (Ref. 49). Therefore this value was used for the average conditions cases. The flit rate for ideal conditions was assumed to be twice the actual value or $40 \mathrm{ft} / \mathrm{min}$.

Roof support advance, which occurs twice during the cycle for the 1980 systems was identified at a rate of 45 seconds per unit under actual operating conditions (see Ref. 49). The design rate for these same units was specified as 30 seconds per unit (see Ref. 49). Therefore, support advance was assumed to require 30 seconds for the 1980 ideal conditions cases and 45 seconds for the 1980 average conditions cases.

For the 2000 shortwall systems, a different approach was selected for support advancement. This support design, instead of using hydraulic cylinders to advance supports by sliding as in the 1980 systems, provided a walking mechanism with specially designed 


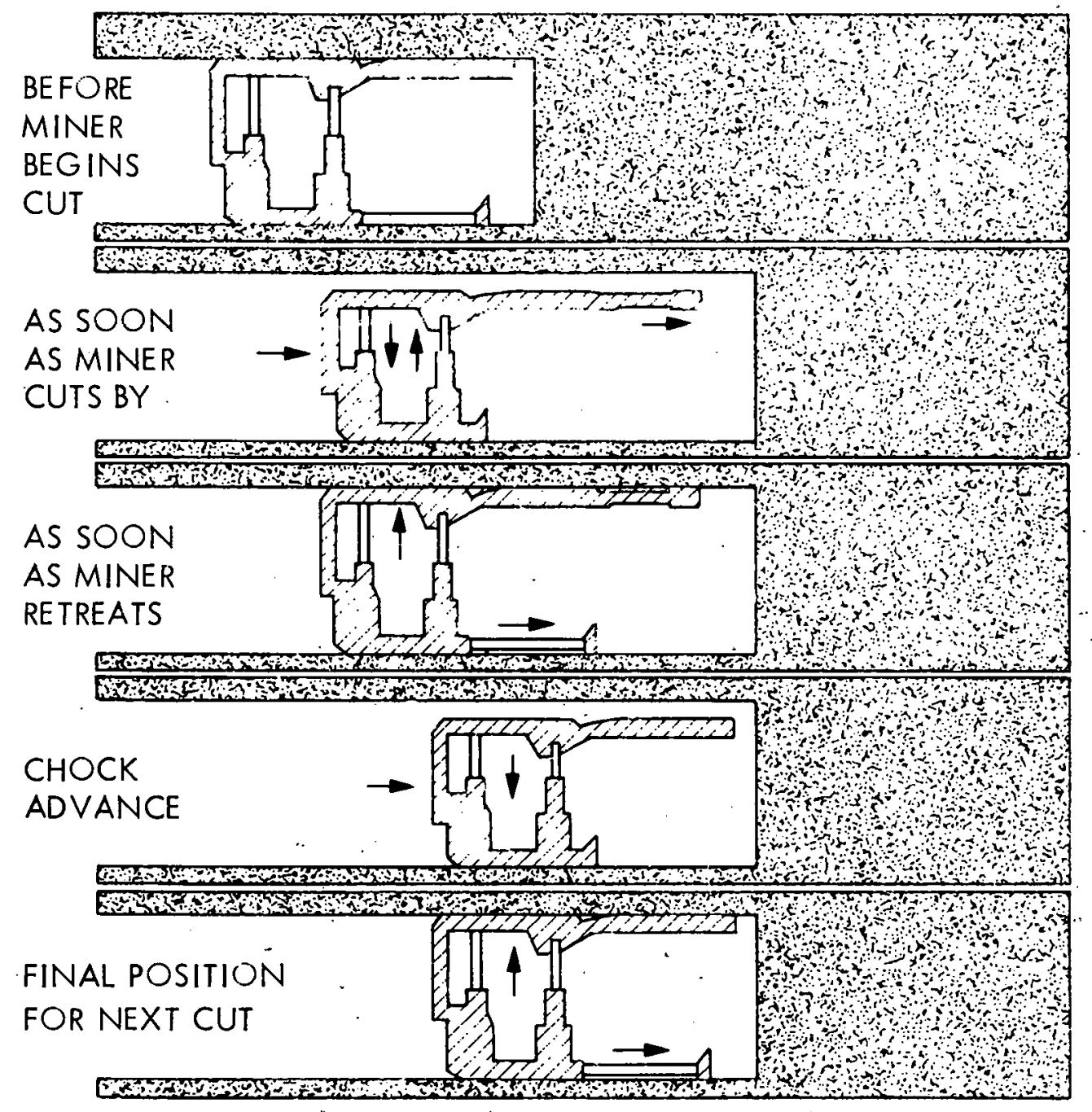

Figure 3-2. Sequence of Face Operations for 1980 . Shortwall systems (Ref.. 5). 
floor beams (see Ref. 30). The designer suggested an advance rate of 10 seconds per unit (for a distance of $7 \mathrm{ft}$ ) under ideal conditions. In average conditions, the assumed advance rate was halved to 20 seconds per unit.

Guide rail advancement, which also occurs twice per cycie for the 1980 systems and once for 2000 systems, was found to occur at a rate of 15 seconds per ram ideally (see Ref. 49). Because information was not available for rates in actual operating conditions, the ideal advance time per ram was doubled to 30 seconds for the average conditions cases.

The application of the aforementioned parameters to the properly sequenced face operations of the shortwall systems produced the cycle times for the face operations. The calculations for the analyses are presented in Appendix B. Figures B-8, B-9, B-10, and B-11 display Gantt Charts of face equipment scheduling for the shortwall cases.

The combination of the face operation cycle time with the appropriate section move elements provided the total cycle time for the shortwall cases. The move elements for shortwall were assumed equal to those used for the longwall and shortwall panel development systems.

Having identified all the variables required for Equation 1 , the system productivities were calculated and are displayed in Table 3-8 along with total cycle times. All details leading to the results are shown in Appendix B. The productivity variations between the average and ideal conditions sets for both study years are caused by differences in the continuous miner parameters, support and guide rail advance times, and section move time. The smail productivity increases for the year 2000 systems occurred for several reasons. The increased advanced rates for the continuous miners caused by a cutter head diameter change ( $3 \mathrm{ft}$ for 1980 and $4 \mathrm{ft}$ for 2000 ) and the elimination of one support/guide rail advance contributed positively. However, the narrower cutter head for the year 2000 shortwall miner had a negative effect.

\section{F. COST ANALYSIS PRODUCTIVITY}

Before the calculated productivities could be used in the cost Analys is section, they required modification to account for the idle time caused by the panel move function. The time required for pane 1 moves varies from system to system. For all room-and-piliar cases and the panel development units for longwall and shortwall, the panel move function time was assumed to be four shifts (Ref。50). The time required for a longwall panel move was selected at 30 shifts (Ref. 51). Shortwall panei move time was reported to be 20 shifts (see Ref. 6). The system productivity values that result from consideration of panel move times are shown in Table 3-9. Calculations supporting the se values are found in Appendix $C$. 
Table 3-8. Total Cycle Time and System Productivity for the Shortwall Systems

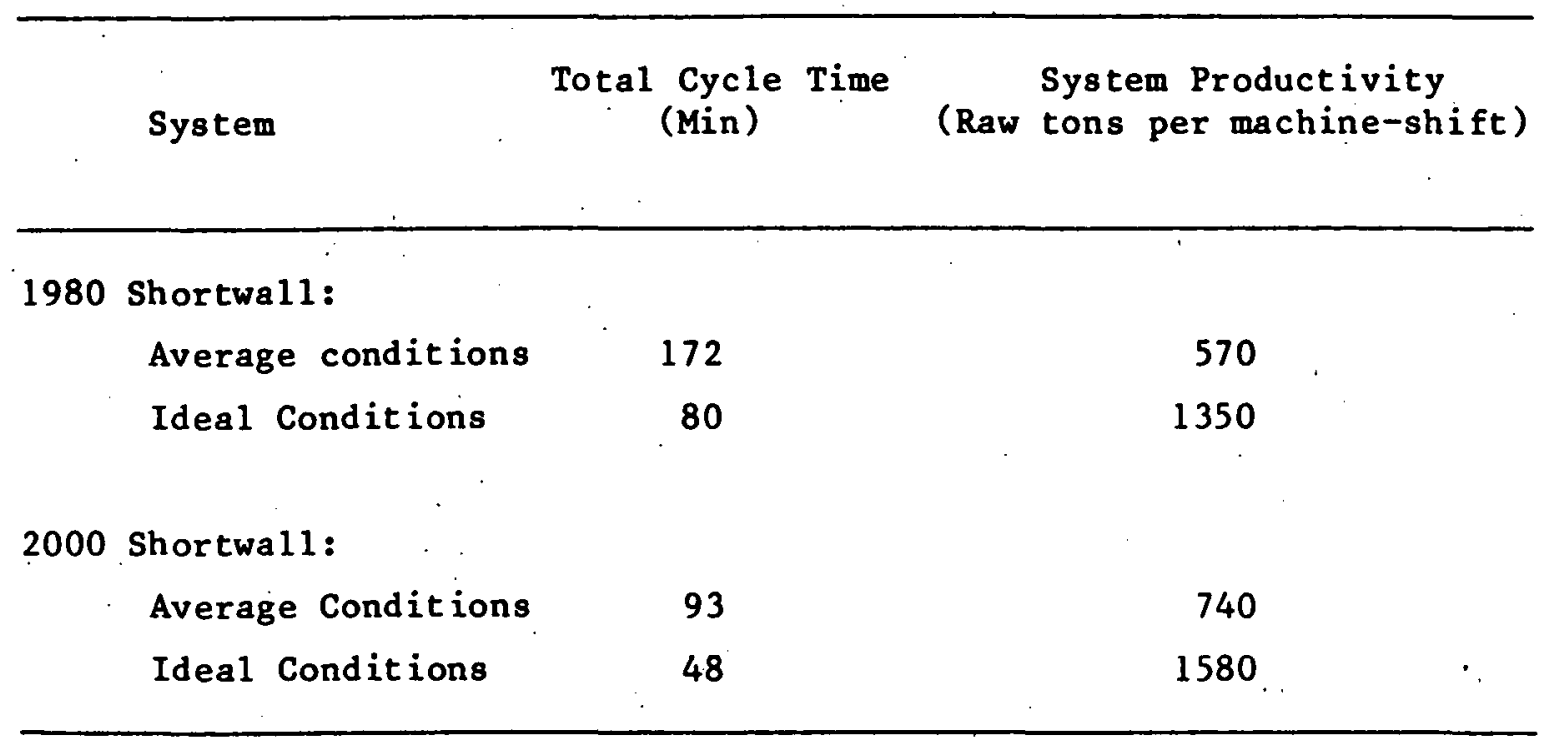

NOTE: Total cycletimes are rounded to the nearest whole number.

Table 3-9. System Productivity Results After Consideration of Panel Moves

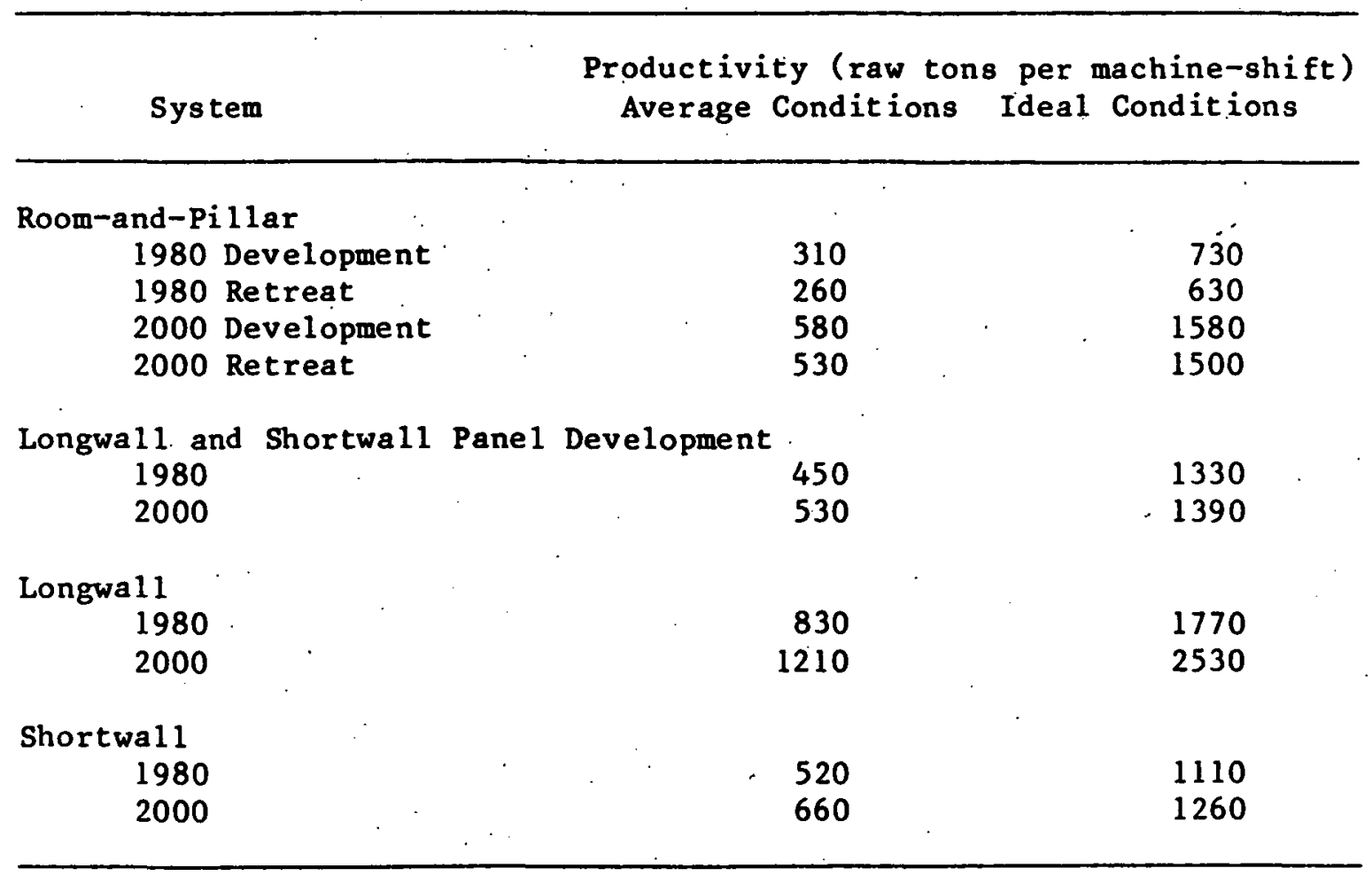


SECTION IV

COST ANALYSIS

\section{A. INTRODUCTION}

The final step of the analysis, the cost analysis, provides breakeven product costs at an assumed return on investment (15\%) for the 12 study cases. To compute these costs, a version of a coal mining cost model for underground mines, developed by NUS Corporation for the Electric Power Research Instituce and modified by JPL, was used (Ref. 52). The model, which followed a building block concept of analysis, incorporates the essential features of mining engineering, actual mining experience, and cost engineering principles which are required to analyze all cost aspects of producing coal from a new underground mine. Model selection was guided by its characteristics and availability. The structure of the model permitted the input of data that characterized the study cases. Other information required for the cost analyses and common to both the study cases and the model cases, was provided by the model. The computational provisions of the model that suited this study were the use of discounted cash flow methods to determine product cost and the ability ro escalate costs from the base year of 1975 to any desired year.

The remainder of this section discusses the identification and quantification of input required for each block of the model in order to characterize the study cases. The model blocks and the flows of information between them are shown in Figure $4-1$.

All costs discussed in this section are in 1980 dollars. The cost escalation factors input to the model were used to update specific cost inputs to either 1980 or year 2000 levels. Further details are presented in appropriate segments of this section.

\section{B. PRODUCTION SIZING}

This segment of the cost analysis provided the input upon which all other segments were built. The input variables were used to derive production section requirements and costs. The input supplied for this segment was placed into two categories: mine characteristics and financial aspects. The mine characteristics included the mining system, mine type, mine life, shifts per day, days per year, recovery factor, reject percentage, design capacity, existence of a preparation plant, and productivity. Tax rates, rate of return, and debt-equity ratio were included in the financial aspects.

\section{Mine Characteristics}

The mining system input referred strictly to the systems previously identified in the study: continuous room-and-pillar, longwall, and shortwall. A drift mine was selected as mine type since 


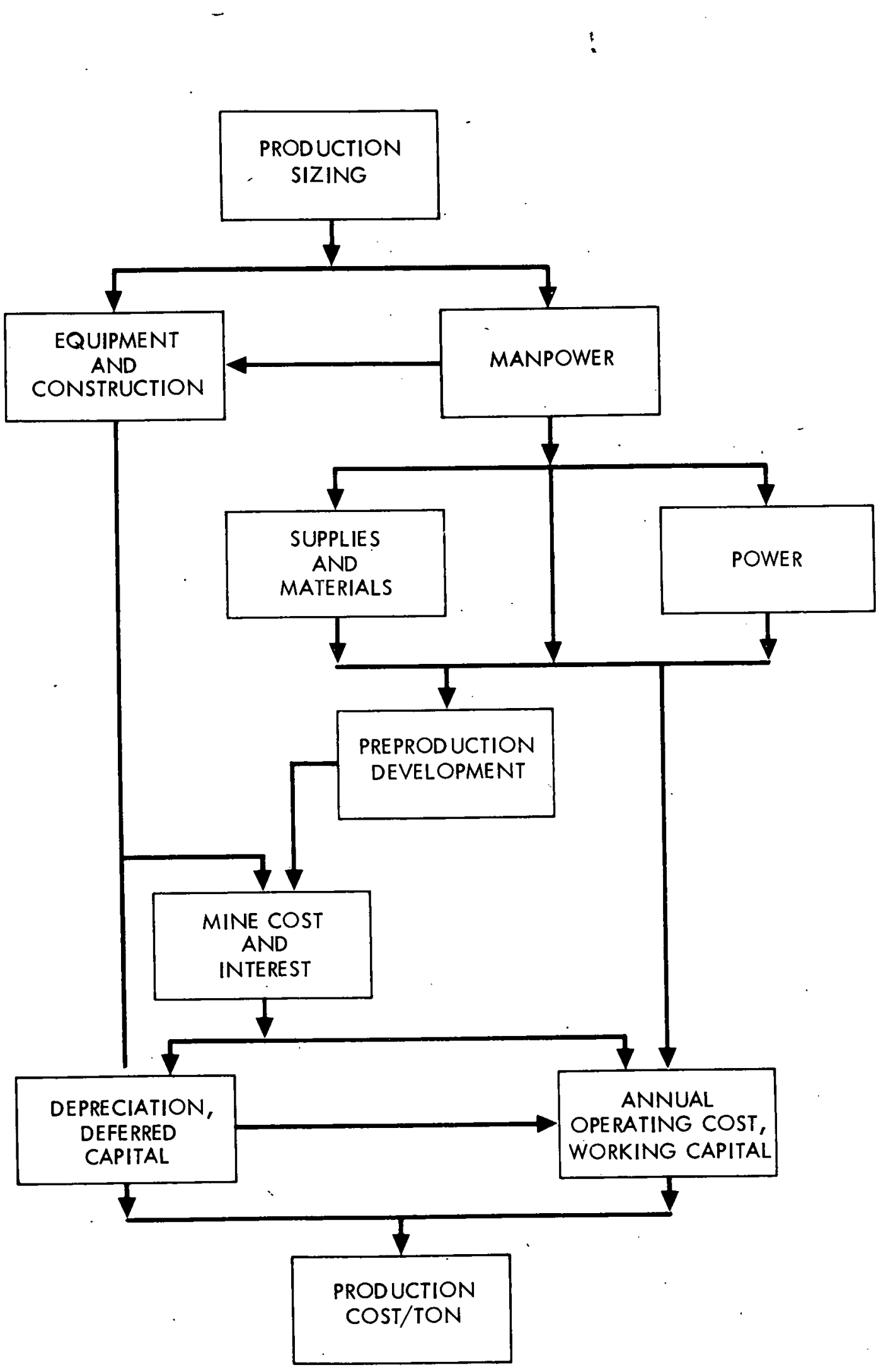

Figure 4-1. Information Flow Diagram for the NUS Underground Mine Cost Model (see Ref. 52) 
the study focused on Eastern Kentucky where most mines are the drift-type (see Ref. 52). A typical mine 1 ife of 20 years not including construction and initial development was used. AII cases were assumed to work three shifts per day and 220 days per year, and to have a preparation plant. In order to calculate the recovery factor for each case, a representative segment of a typical mine configuration was used. This segment included the main headings, a set of cross headings, and an appropriate number of production pane ls. By assuming $100 \%$ recovery from areas that were excavated, the recovery factors of Table 4-1 were achieved. Recovery factors were used in the model to calculate mine seam block size and to identify some equipment requirements.

Table 4-1. Seam Recovery Factors for Study Cases*

Recovery Rate \%

Technology $\quad 1980 \quad 2000$

Room-and-Pillar

43

54

Longwa 11

76

76

Shortwal1

69

69

*The change in recovery from 1980 to year 2000 for room-and-pillar was caused by variations in entry and crosscur centerline dimensions and geometrical considerations of the mine plan.

The reject percent, or percent of waste material in the raw product varies with the mining system (see Ref。 52). NUS Corporation identified the reject percent to be $25 \%$ for continuous room-and-pillar and $21 \%$ for longwal1. The reject percent for shortwall was assumed to be $25 \%$ because the shortwall systems use the same coal winning machine as room-and-pillar.

Design capacity, in terms of clean tons, was developed through the combination of shifts per day, days per year, productivity, reject percent, and number of machine units. The number of machine units for all room-and-pillar cases was assumed to be four. The number of units for the longwall and shortwall cases was varied, however. Each longwall and shortwall case was as sumed to have one panel extraction unit. An appropriate number of panel development units, based upon the relative speed of panel development and extraction, was selected 
Table 4-2. Number of Machine Units per Study Case

\begin{tabular}{ccc} 
& \multicolumn{2}{c}{ Number of Units } \\
Technology & Average Conditions & Ideal Conditions \\
\hline Room-and-Pillar & & \\
1980 & 4 & 4 \\
2000 & 4 & 4 \\
Longwall & & 3 \\
1980 & 4 & 3 \\
2000 & 4 & 3 \\
Shortwal1 & & \\
1980 & 4 & \\
\hline
\end{tabular}

Table 4-3. Design Capacity of Study Cases

\begin{tabular}{ccc}
\hline & \multicolumn{2}{c}{ Capacity (clean tons) } \\
Technology & Average Conditions & Ideal Conditions \\
\hline $\begin{array}{c}\text { Room-and-Pillar } \\
1980 \\
2000\end{array}$ & 574,200 & \\
& $1,108,800$ & $1,346,400$ \\
1980 & & $3,049,200$ \\
2000 & $1,136,652$ & \\
Longwa11 & $1,459,920$ & $2,309,802$ \\
1980 & & $2,768,634$ \\
2000 & 925,650 & $1,866,150$ \\
& $1,113,750$ & $1,999,800$ \\
\hline
\end{tabular}

- also. Table 4-2 presents the number of machine units per case, and Table 4-3 identifies the resulting design capacities. Further details concerning design capacity calculations are found in Appendix $C$. 


\section{Financial Aspects}

The input variables within this category were held constant for all study cases. The tax rates were selected at $48 \%$ for Federal taxes and $2 \%$ for state and local taxes combined. A $15 \%$ rate of return was used. A $100 \%$ equity investment was assumed.

\section{MANPOWER}

This segment provided the requirements for production section labor, support labor and salaried personnel based upon the number of production sections identified in the Production Sizing segment. Also, the cost for labor and salaried personnel required identification for input.

The salaried personnel requirements for each study case are shown in Appendix $C$. The job categories 1 isted there demonstrate the basic differences from one system to another. In all 2000 cases, a control system engineer was provided because of equipment changes between the 1980 and 2000 cases. The input required for the NUS model was the number of salaried personnel and the average annual salary. Table 4-4 shows the personnel requirements for each case. The different salary requirements for the cases are related to capacity variations. The average salaries for the 2000 cases were escalated from their 1980 dollar values calculated in Appendix C to their 2000 dollar values using the cost update factor found in Appendix D.

Appendix $\mathrm{C}$ also contains the hourly labor requirements for each study case. Perusal of each case identifies the job category changes required between cases. Three different segments of the labor force were used: surface, underground general, and underground production crews. The number of support laborers (surface and underground general) was varied with respect to design capacity. Also, the number of production crew members changed. These hourly labor changes correspond to equipment and system configuration differences. In addition to requirements, Appendix $\mathrm{C}$ also provides average hourly labor costs (dollars per person per day). These costs were used to develop the manpower cost update factors found in Appendix $D$. The input of such factors into the model escalated the base 1975 dollar values of the model to the appropriate 1980 and 2000 dollar values. Table 4-4 also presents the hourly labor requirements as extracted from Appendix $C$.

\section{EQUIPMENT AND CONSTRUCTION}

This segment of the model provided the equipment and construction requirements, and associated capital costs. Development capital costs as well as production capital cost were computed. The transition between the development period and the production period in the NUS model occurs at the point in time when the last production unit is entered into the mine. The capital cost categories included 
Table 4-4. Salaried and Hourly Personne1 Requirements for Study Cases

\begin{tabular}{ccccc}
\hline & \multicolumn{2}{c}{ Average Conditions } & \multicolumn{2}{c}{ Ideal Conditions } \\
Technology & Salaried & Hourly & Salaried & Hourly \\
\hline Room-and-Pi1lar & & & & \\
1980 & 53 & .222 & 69 & 288 \\
2000 & 67 & 270 & 96 & 428 \\
Longwal1 & & & & \\
1980 & 66 & 293 & 83 & 353 \\
2000 & 70 & 318 & 89 & 392 \\
Shortwa11 & & & & \\
1980 & 59 & 267 & 72 & 317 \\
2000 & 68 & 285 & 75 & 323 \\
\hline
\end{tabular}

production section equipment, haulage system auxiliary equipment, site preparation and construction, exploration, mine abandonment, and miscellaneous items.

The logic of the NUS model proved to be quite beneficial in the generation of capital requirements and the computation of capital costs. Only the production section equipment requirements and costs needed to be separately input. The remaining categories were handled internally by the model. subject to the inputs of Production Sizing.

The production section equipment requirements and costs are itemized in Appendix C for all study cases. Most 1980 equipment costs were supplied by an internal staff effort that updated 1975 NUS costs to their 1980 values ( $\operatorname{Ref}$.53). The 1980 costs were obtained from manufacturer quotations. Other sources of equipment costs are reported in Appendix $C$. Table 4-5 provides the capital cost for each particular machine unit used in this study. The unit costs for the 2000 cases are shown as 1980 dollars in Table 4-5. However, all equipment costs were escalated with the cost update factors of Appendix $D$ by the model.

\section{E. SUPPLIES AND MATERIALS}

This model segment provided the supplies and materials cost per clean ton for each study case. The cost computation was based on an equation developed by analysis of data from a large number of mines (see Ref. 52). The equation relates supplies and materials cost to labor costs. One equation was developed for all current technologies. 
Table 4-5. Machine Unit Costs in 1980 Dollars*

\section{Capital costs}

Unit

(Nearest thousands of dollars)

Longwal1 unit

1980

$\$ 5,411$

2000

$\$ 6,935$

Shortwall unit

1980

$\$ 2,445$

2000

$\$ 2,640$

Continuous miner units

R\&P: 1980

$\$ 1,126$

2000

$\$ 1,935$

Longwa 11 and Shortwa 11

Development:

Average conditions

1980

$\$ 1,057$

2000

$\$ 1,836$

Ideal conditions

1980

2000

$\$ 1,107$

$\$ 1,836$

*NOTE: Cost variations occur between the ideal and average conditions sets for panel development because component needs change for roof bolters, auxiliary fans, trickle dusters, and panel conveyors.

F. POWER

Although the NUS model had provisions to calculate power cost per clean ton through a, labor cost approach similar to supplies and materials cost, an alternative technique suggested by NUS and used by others was adopted (see Ref. 52, and Refs. 54 and 55). Basically, the approach identified the power-consuming components and their horsepower requirements, then combined the total horsepower of each component category with an estimated operating time per day to produce the power requirements in kilowatt-hours per day. The multiplication of the daily power requirements with the operating days per year and an assumed power cost provided the annual power cost. From that point, use of the annual design capacity in clean tons identified power cost per clean ton. The resultant costs are displayed in Table 4-6. 
Estimates of operating times were developed from Appendix B. Further information concerning the inputs to the power costs can be found in Appendix C. The power costs for the 2000 cases were escalated to 2000 dollars by the NUS model with the power update factor found in Appendix D.

\section{G. PREPRODUCTION DEVELOPMENT}

Preproduction development refers to the period during which the initial segment of main arteries of the mine are being developed. The period commences when the first machine unit begins operation and terminates when the final machine unit starts production. This time period is important because within the financial analys is the decision was made to capitalize all costs incurred during development. The purpose of this model segment is to identify these costs.

In order to simulate the case studies of this effort, several inputs required identification. Included were the extent of the development period in years, the tonnage produced during the period, and the length of advance in the main heading and cross-headings during the period. All four parameters were computed with the aid of the system productivities and proper scheduling of machine units into an idealized mine plan layout. The layout is shown in Figure 4-2, and the resulting input values are presented in Appendix $E$.

Table 4-6. Estimated Power Cost per Clean Ton for Study Cases

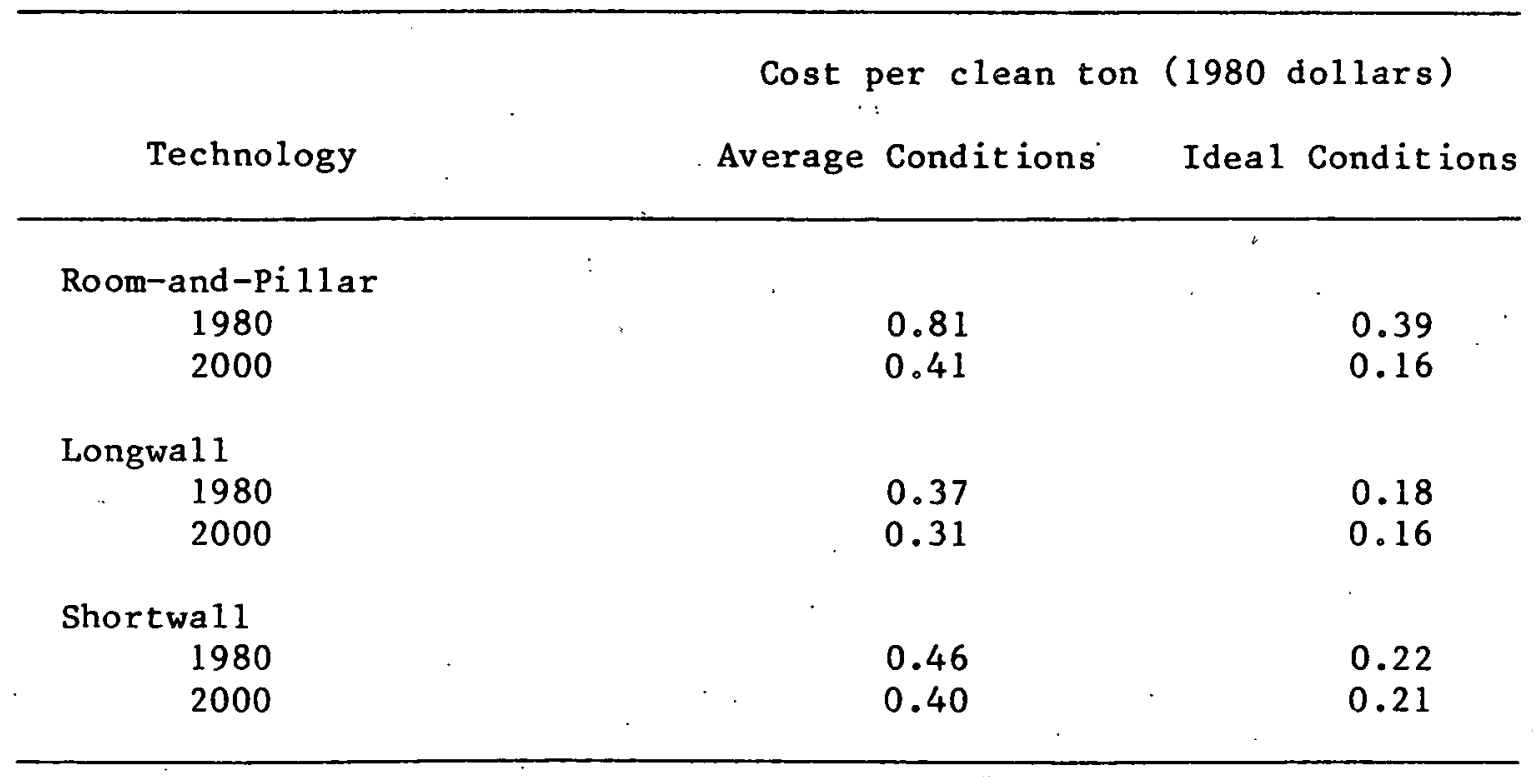




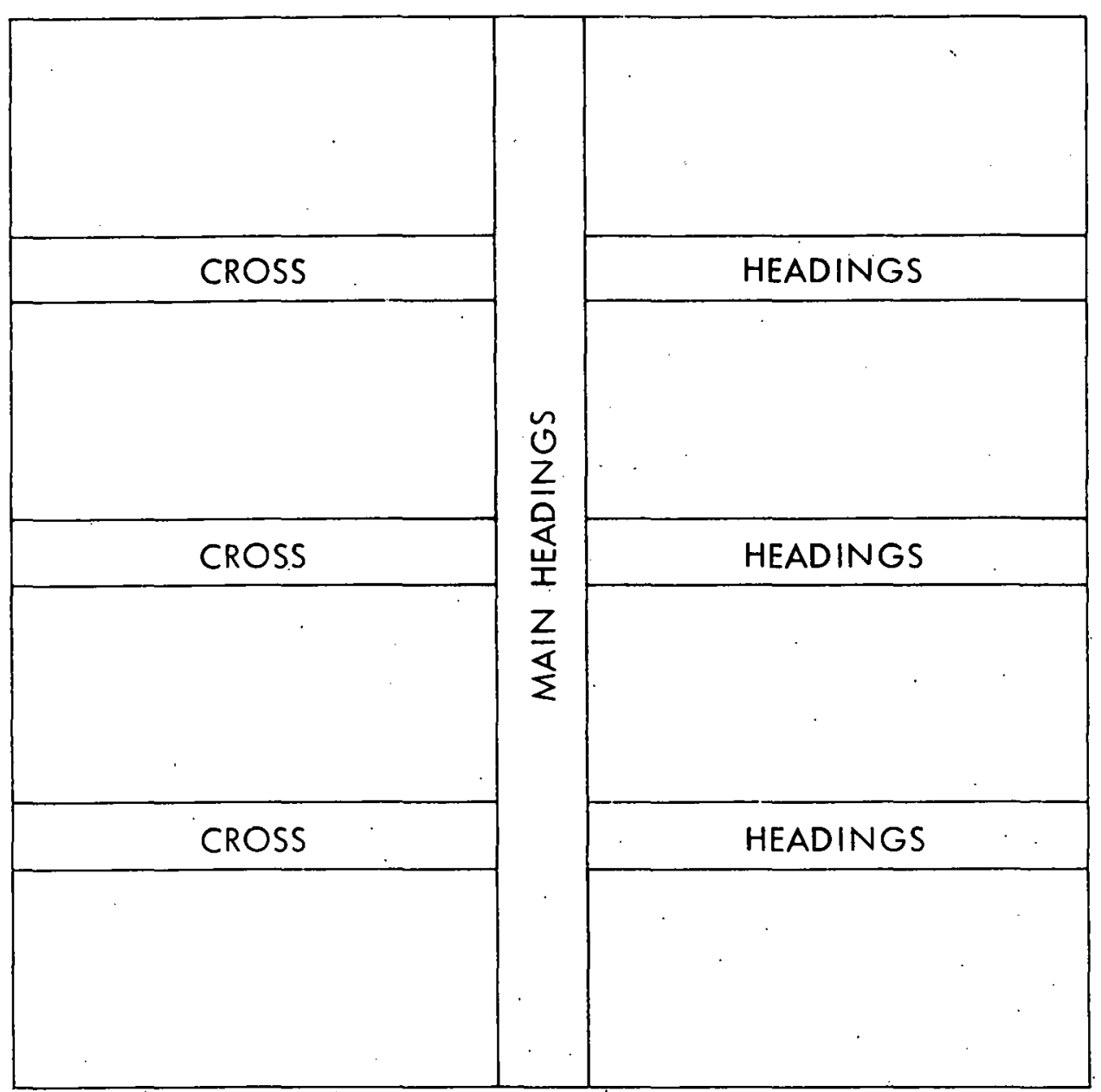

Figure 4-2. Idealized Mine Plan for Development Computations

$$
4-9
$$


H. OTHERS

As seen in Figure 4-1, there are four remaining segments of the model. Because none of these segments required direct input to them (they used information generated in previous segments) only a brief mention of their function will be made. The Initial Capital Investment segment uses previously calculated costs as a basis for computing the total initial capital investment. The determination of yearly depreciation charges and deferred capital investment for the life of the mine are the responsibility of the Deferred Capital Investment Depreciation segment. The straight-line method of depreciation was applied. The Annual Operating Cost, Working Capital segment includes two parts. The estimated costs of other segments are totalled and used to identify indirect and fixed costs that are functionally related to them. Also, the working capital requirement is estimated to be proportional to the annual operating costs minus depreciation. The final segment of the model, Production Cost, conducts a discounted cash flow analys is to determine the production cost per ton for a specified rate of return.

\section{COST ANALYSIS RESULTS}

The introduction of the aforementioned data into the NUS Model provided break-even production cost per clean ton for each study case. These costs were based on a $15 \%$ rate of return. Because the model computed the costs for the 2000 cases in 2000 dollars, they were deflated to 1980 dollars for comparison with the 1980 cases. The annual GNP deflators used to accomplish the transformation are shown in Appendix D. While the important output of the model is displayed in Appendix $E$ for documentation purposes, the production cost results for each case are shown in Table 4-7. 
Table 4-7. Production Cost per Clean Ton

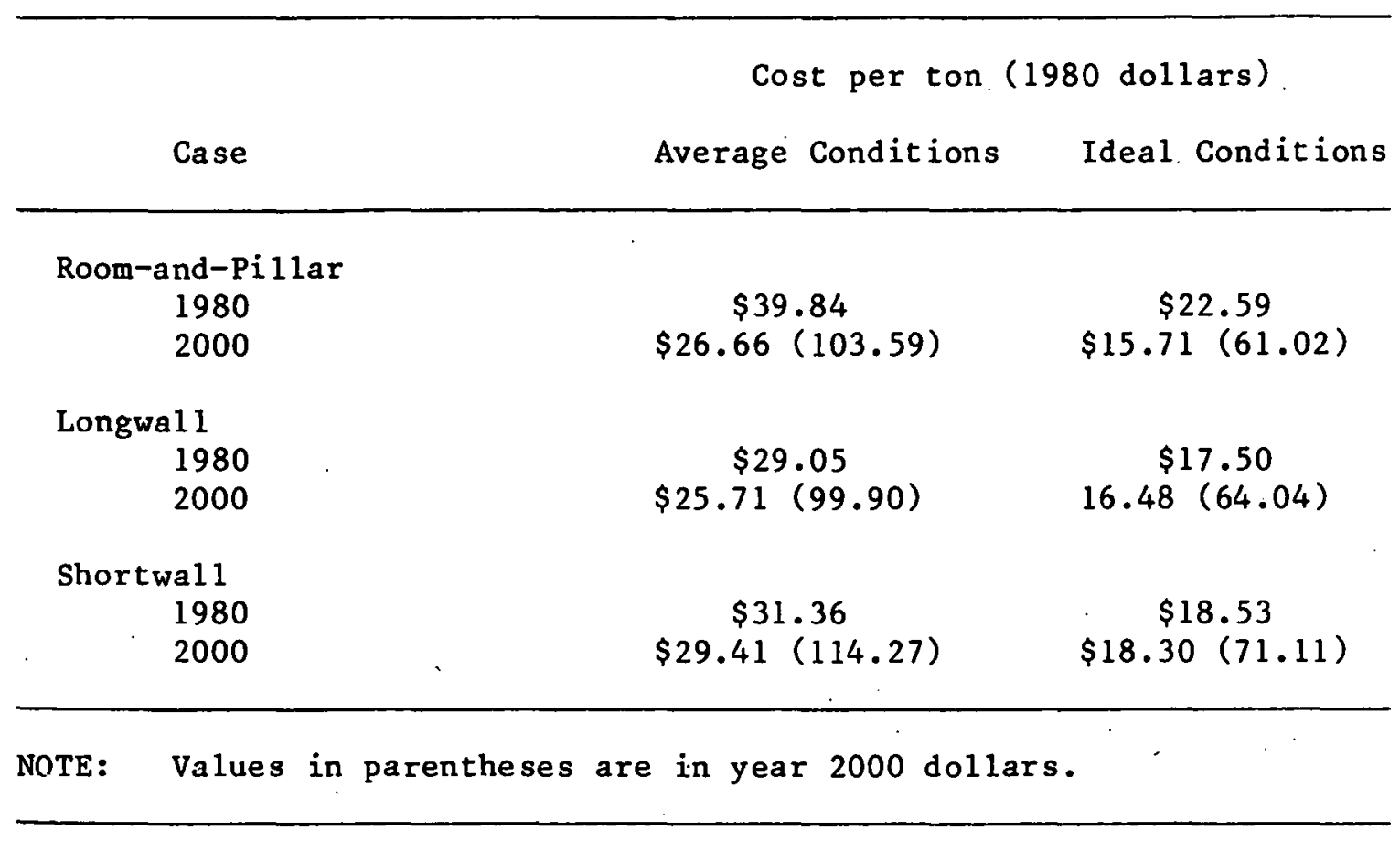


SECTION V

\section{DISCUSSION OF RESULTS}

As mentioned in previous report sections, the study approach was to fulfill two requirements. The 1980 cases were to provide a check to insure that the approach produced reliable results. The average conditions cases for the 1980 systems should provide results, both system productivity and production costs, that correspond well to current experiences. Secondly, the results of the year 2000 cases were developed to establish a measure of economic performance against which advanced system concepts will be compared. It is assumed, and quite possible, that these year 2000 systems will provide the competition to any advanced coal extraction system developed by the Jet Propulsion Laboratory through contract to the U.S. Department of Energy. In order to be competitive, the advanced system must at least match the economic performance of the industry workhorses at the time of its commercialization.

Because difficulty will be encountered in trying to estimate the effects of mining conditions on the productivity of new concepts, comparison with future competitors should be based on ideal mining conditions; hence, the year 2000 ideal conditions cases. However, should an attempt be made to establish performance levels of conceptual systems as conditions deteriorate, any comparison should consider both the average and ideal conditions cases of the extrapolated 2000 systems.

Before further discussion is presented concerning the results, two major limitations of the study should be noted. First, the data required for the production analys is approach were not easily available. Secondly, the data that were available did not always appear in consistent usable form. Some data, therefore, had to be modified. Finally, the seam height assumption proved to be quite significant. Because the "bottom-up" approach required selection of a seam height, the results of the entire study are only applicable to a 6-ft seam. Before a conceptual comparison is made, this limitation must be acknowledged or eliminated. It is suggested that similar studies be initiated for other representative seam heights.

A review of the literature showed a close correlation between the productivity values of other studies and the 1980 average conditions cases. One study that analyzed 326 continuous room-and-pillar systems, established an average productivity of 281 tons per. machine-shift (TPMS) with an average seam height of 63 in.; whereas the average conditions case in this study resulted in 290 TPMS for a 6-ft seam ( $\operatorname{Ref} .56$ ). Other room-and-pillar studies presented similar results: 300 to 310 TPMS for a 6-ft seam (see Refs. 54, 55). It is quite evident from the se comparisons that the productivity estimate for the 1980 average conditions room-and-pillar case is extremely realistic. 
While moving baseline study estimated 830 TPMS for the 1980 average conditions longwall system, five double-ended ranging shearer faces working 6-ft seams, obtained a combined average productivity of 790 TPMS (see Ref. 26). Another longwall study calculated an average productivity of 900 TPMS for a $7.5 \mathrm{ft}$ seam (see Ref. 20). Although the productivity result of baseline study compares well with these other study results, the sample size of the comparators is too small to judge the accuracy of the baseline estimate. It is hoped that future information-gathering will permit a sound judgment on the moving baselines.

Although available shortwall studies did not report productivity with respect to seam height, the 520 TPMS estimate of this study was close to the midpoint of the ranges reported - 200 to 980 TPMS (see Refs. 6, 57). Additionally, it was suggested that current shortwall productivity should not vary, appreciably, from panel development productivity (Ref. 58). The same holds for the baseline study - 450 TPMS for the shortwall panel development and 520 TPMS for the shortwall production unit. Again, the sample size of the comparators does not warrant a sound judgment as to the accuracy of the baseline estimate. However, as with the 1980 longwall case, the initial comparison is quite encouraging.

A comparison of study cost results, that includes a $15 \%$ return on investment, with current spot market prices and long-term contract prices, established an acceptable correlation. Current spot market prices range from 20 to 43 dollars per ton, producing an average value of $\$ 31.50$ per ton (Ref. 59). Also, long-term contract. prices are presently in the mid-to-high twenty dollar range (Ref. 60). The 1980 average conditions case costs for longwall (\$29.05) and for shortwall $(\$ 31.36)$ reflect favorably. However, the 1980 R\&P cost $(\$ 39.84)$ does not. This discrepancy can be easily justified, however. The value represents the selling price requirement for a new room-and-pillar mine including plant site, development openings, and preparation plant. The result is a high initial capital investment per annual ton at a rather low labor productivity ( 9.5 tons per worker-day). But, the labor productivity figure is close to that experienced today. A 1976 study of a hypothetical room-and-pillar mine established a selling price of $\$ 31.50$ per ton in order to achieve a $15 \%$ return on investment (see Ref. 32). The investigators recognized then that underground mines were not achieving such a high realization for their coal. Several reasons for their discrepancy were given, and in all probability, apply here since their 1976 selling price escalated to 1980 dollars $(\$ 44.6 .1)$, exceeds the value presented in this study $(\$ 39.84)$. Operating mines were either developed before inflation escalated capital investment items to their current levels, have lower mining costs, or may not be achieving a $15 \%$ return on investment.

Scrutiny of the break-even production cost per clean ton for the year 2000 cases indicates that longwall technology will produce coal most cheaply in average conditions, but lose its supremacy to continuous room-and-pillar as ideal mining conditions are approached. 
This trend can be easily seen in Figure 5-1, where production cost is plotted against mining conditions. The assumption underlying this plot is that a. linear relationship exists between production cost and degree of geological difficulty. The implication of Figure 5-1, considering that ideal mining conditions rarely exist in nature, is that longwall technology should be the comparator for advanced systems technology. However, if longwal1 technology does not match we 11 with the general characteristics of a selected target resource, then other technologies should be given consideration. Such is the case for the coal fields of Eastern Kentucky where mine size" is generally small (less than 200,000 tons per year) and the lateral extent of coal blocks may not be appropriate for longwall technology. Therefore, attempts to develop new systems for Eastern Kentucky should recognize room-and-pillar technology as the probable competitor.

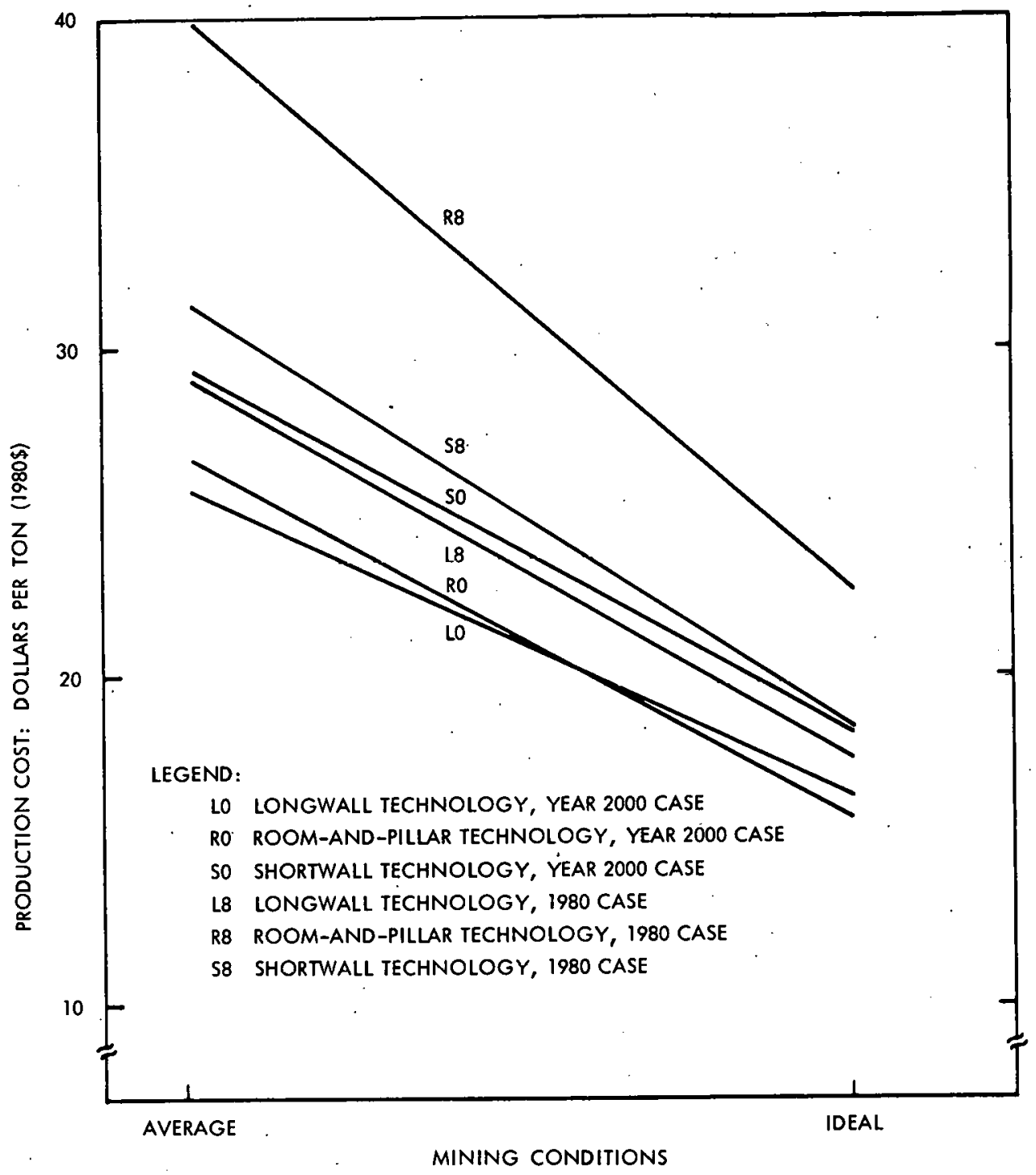

Figure 5-1. Production Cost per Clean Ton Versus Mining Conditions for Room-and-Pillar, Longwall, and Shortwall 
SECTION VI

REFERENCES

6-1 
1. National Coal Association, Washington, D.C., Coal Facts (1978-1979).

2. Frantz, R. L., King, R. H., and Bickerton, C. R., Analysis, Evaluation, and Selection of Candidate Continuous Mining Systems Suitable for Automatic Operation Under Remote Supervisory Control: Tasks A and D Appendix, USBM Contract No. J0166007 (December 1977).

3. Business Week, "Longwall Gives Coal. Productivity A Boost," (June $12,1978)$.

4. Kuti, J., "Longwall Mining in America," Mining Engineer (November 1979).

5. Stefanko, Ro, Professor of Mining Engineering, unpublished manuscript, Pennsylvania State University, University Park,. Pennsylvania (1977).

6. Pollard, T., "World Wide Developments in Shortwall and Wide Web Mining Techniques," The Mining Engineer, (November 1975).

7. Katen, K. P., "Analysis of United States Shortwall Mining Practices," Mining Congress Journal (January 1979).

8. Gordon, P. G., et al., "A Review of Underground Mining Equipment Research and Development," Jet Propulsion Laboratory, Internal Report 5030-482 (November 1980).

9. Stefanko, R., and King, R. H., Conference on R\&D, "Needs of Innovative Mining Methods," unpublished report for U.S.B.M., Contract No. J0155161 (Apri1 1975).

10. Frantz, R. L., King, R. H., and Bickerton, C. R., "First Conference on the Automated Remote Controlled Continuous Mining Program," unpublished report to U.S. Bureau of Mines (December 1975).

11. Frantz, R. L., King, R. H., and Bartsch, D., "Report on the Second Subprogram Coordination Meeting on the Automated Remote Controlled Continuous Mining Program," unpublished report to U.S. Bureau of Mines (March 1977).

12. National Mine Service, Automated Extraction System, Final Report, DOE Contract No. ET-75-C-01-9011 (March 1977).

13. Harrold, R., "Supports Boost Output and Safety," Coal Age, (June 1979).

14. Toore, D. C., Vice President, Marketing, Long-Airdox Company, private communications (November 1976). 
15. Little, A. D., Inc., Conceptual Design of a Fully Automated Continuous Mining System Operating Under Remote Supervisory Control, Final Report, U.S. Bureau of Mines, Contract No. J0166007 (December 1977).

16. McMahon, K. C., and Baldwin, A. N., Automated Continuous Miner Preliminary Design, Final Report, USBM Contract No. H0242057 (June 1975).

17. Mahaffey, M., Department of Energy, Pittsburgh, Pennsylvania, private communications, (September 1979).

18. Mayercheck, W., Department of Energy, Pittsburgh, Pennsylvania, private communication (Apri1 1979).

19. Dunbrack, D., Foster-Miller Associates, Inc., Waltham, Mass., private communication (May 1979).

20. Schroeder, E. W., et al., Analysis of the Economic Feasibility of the Kloswall Longwall Mining System, U.S. DOE Report No. HCP/T77-01-8915-01(7) (December 1978).

21. Rybak, C., Bendix Corporation, Denver, Colorado, private communication (May 1979).

22. Schroeder, E. W., et al., Analysis of the Economic Feasibility of the Kloswall Longwall Mining System, U.S. DOE Report No. HCP/T77-01-8915-01(7) (December 1978).

23. Gross, M. A., Department of Energy, Pittsburgh, Pennsylvania, private communication (April 1979).

24. George C. Marshall Space Flight Center, NASA, Development of Mining Guidance and Control Systems, Report No. AW-11 (September 1977).

25. Summers, D., Professor of Mining Engineering, University of Missouri-Rolla, private communication (July 1979).

26. COMINEC, Conceptual Design of an Automated Longwal1 Mining System, U.S. Bureau of Mines Final Report, Contract No. S0241051, NTIS PB-263 213, (April 1976).

27. Olsen, J. J., and Tandanand, S., Mechanized Longwal1 Mining, USBM Information Circular 8740 (1977).

28. Casanova, P., MINEX, Paris, France, private communication followed by a letter (July 1979).

29. Freed, D., National Mine Service Company, Nashville, I1linois, private communication (November 1979).

30. Kiskis, J., Jet Propulsion Laboratory, Pasadena, California, private communication (November 1979). 
31. Curry, K. C., et al., Shortwall Mine Availability and Delay Analys is, Jet Propulsion Laboratory Report No. 5030-47 (December 1976).

32. Frantz, R. L., and R. H. King, Study of Human Factor As pects of an Automated Continuous Mining System, USBM Grant No. S0144115 (March 1977).

33. Curry, K. C., et al., Longwa11. Mine Availability and Delay Analys is, Jet Propulsion Laboratory Report No. 5030-46 (December 1976).

34. Hawkins, S. A., Management Engineers Incorporated, Reston, Virginia, private communications (April 1980).

35. Davis, J. J., Associates, Inc., Industrial Engineering Study of Continuous Mining Systems, Final Report USBM Contract No. J0357096 (August 1977).

36. Goodman Equipment Corporation, Chicago, Illinois, Haulmor Shuttle Cars, Catalog 198-A.

37. Joy Manufacturing Company, Pittsburgh, Pennsylvania, LOSC22-C Shuttle Car, Bulletin No. J-226.

38. National Mine Service Company, Pittsburgh, Pennsylvania, NMS Torkar Type 48B, Bulletin T-579.

39. Torre, D. C., Continuous Haulage: A Practical Reality, Chapter 53 of 1974 RETC Proceedings, Society of Mining Engineers.

40. Schroeder, E. W., et al., Analys is of the Economic Feasibility of the Kloswall Longwall Mining System, U.S. DOE Report No. HCP/T77-01-8915-01(7) (December 1978).

41. Joy Manufacturing Company, Advertisement Bulletin $1 / 79$.

42. Jones, E. H. and Kuti, J., Dust and Its Effect on Longwall Mining, Mining Congress Journal, (August 1979).

43. Thomas, R. 0., Jr., Ventilation Problems Associated with Longwall Mining, Mining Congress Journal, (July 1979).

44. Coal Age, Equipment News (June 1979).

45. National Coal Board, Chainless Haulage Systems for Power Loaders, U.S. DOE Report No. FE/SFPM-1(78) (1978).

46. Bickerton, C. R., Jet Propulsion Laboratory, Pasadena, California, personal files.

47. Elkin, H., Manager of Underground Operations, Kaiser Steel Corporation, Raton, New Mexico, private communications (May 1980). 
48. Herhal, A. J., et al., Longwall Conveyor System Study, DOE $\mathrm{FE} / 8915$ (2)-1 (June 1978).

49. Dowty Corporation Bulletin, Principles of Shortwall Mining.

50. Strittmatter, B., Mining Engineer, North American Coal

Corporation, Blairsville, Pennsylvania, private communications (December 1979).

51. Brooks; N. E., Longwall Moving Procedure at Consolidation Coals Moundsville Operation, Mining Congress Journal (June 1979).

52. NUS Corporation, Coal Mining Cost Models - Underground Mines, Final Report, Volume 1, EPRI Report EA-437 (February 1977).

53. Gordon, P. G., Updating the NUS Underground Coal Mining Computer Model to 1980 Prices, IOM FF-345-79-239, Jet Propulsion Laboratory, Pasadena, California (December 17, 1979).

54. Katell, S., et al., Basic Estimated Capital Investment and Operating Costs for Underground Bituminous Coal. Mines, Bureau of Mines IC 8689 (1975).

55. Duda, J. R., Basic Estimated Capital Investment and Operating Costs for Underground Bituminous Coal Mines Utilizing A Continuous Mining System, U.S. Department of Energy Report No. FE/EES-79/1 (November 1978).

56. Suboleski, S. C., Effects of Physical Conditions on Continuous Miner Production in Underground Coal Mines, The Pennsylvania State University, Ph.D., (1978).

57. Peng, S. S., and Duk-Won Park, Shortwa11 Mining in the U.S.: A Record of Faj.lure and Success, Coal Mining and Processing, (December 1977).

58. Green, L. E., and Palowitch, E. R., "Comparative Shortwall and Room-and-Pillar Mining Costs," USBM IC 8757 (1977).

59. Wall Street Journal, (June 17, 1980).

60. Suboleski, S. C., Vice President, Continental Bank, Chicago, I1linois, private communications (February 1980).

61. Gangal, M., Jet Propulsion Laboratory, Pasadena, California private communication (January 1981). 


\section{APPENDIX A \\ MINING CONDITIONS DESCRIPTIONS}

The purpose of Appendix A, Mining Conditions Descriptions, is to provide the reader with a description of the geological setting for the twelve cases presented in this report. The descriptions were developed from reports that discuss the variability of mining conditions and the effect the variability has on selected underground coal mining technology. The mining conditions were not used in any way to determine the value of equjpment performance parameters or the mode of mining function execution. The determination of these study inputs is discussed in section III, Production Analysis. 
PANEL DEVELOPMENT:

Description developed from information found in unpublished manuscript of Robert Stefanko, Professor of Mining Engineering, Pennsylivania State University, University Park, Pennsylvania, 1977.

6-ft seam
Smooth, hard, dry floor with grades less than $1 \%$
Roof bolts in $4 \mathrm{ft} \times 4 \mathrm{ft}$ or $5 \mathrm{ft} \times 5 \mathrm{ft}$ pattern with $4-\mathrm{ft}$
bolts, no falls, entries to $20-\mathrm{ft}$ wide
No methane build-up at face with minimum ventilation
requirements ( $3000 \mathrm{cfm}$ )
Coal easily cut by continuous miners, no special bit
lacing or angles required
Moderate seam depth - 400 to $800 \mathrm{ft}$
Damp floor, but no standing water mobile equipment
(rubber-tired and crawler-mounted) movement does not
deteriorate floor conditions, no dust problems, crawler
traction ideal

LONGWALL PRODUCTION: Developed from information in several references.

1. COMINEC, Conceptual Design of an Automated Longwa11 Mining System, USBM Final Report, Contract No 50241051, NTIS PB-263213, Apri1 1976.

2. Kuti, J., "Longwall vs. Shortwall Systems," paper presented at AMC Annual Coal Convention, May 1975.

3. Stefanko, R., as before.

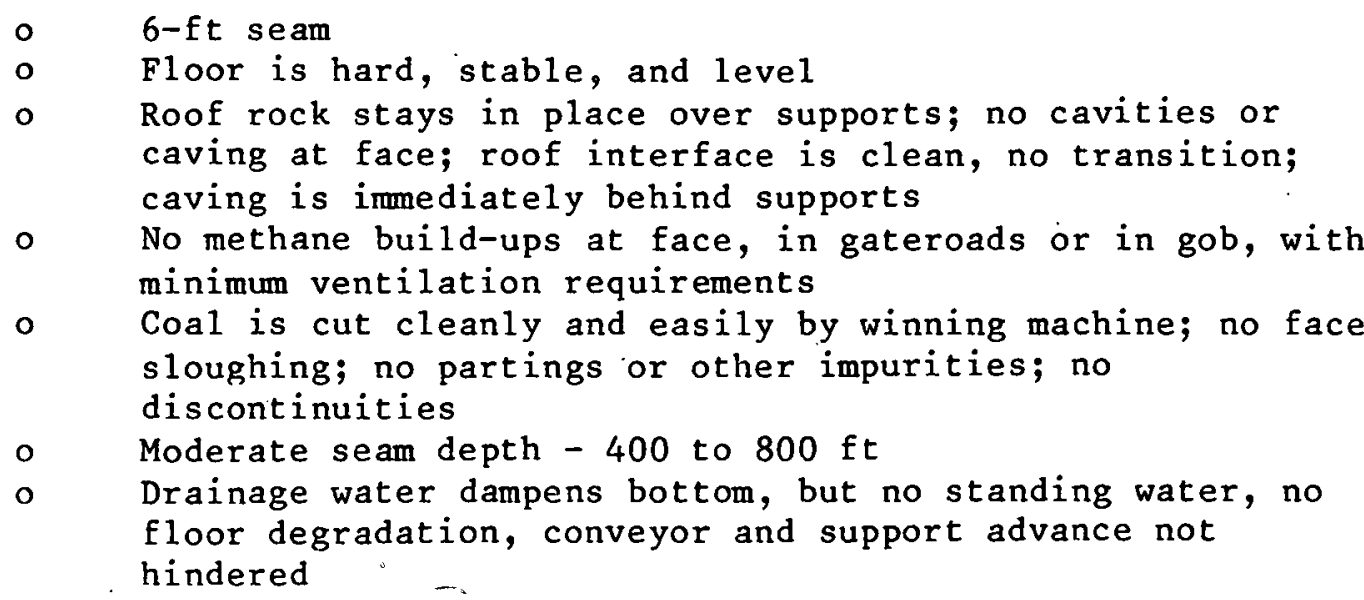


PANEL DEVELOPMENT: Same reference as PANEL DEVELOPMENT, IDEAL CONDITIONS.
o 6-ft seam
- Weak shale or hard fireclay occasionally interferes with equipment operations, ruts develop with regular use, grades to $7 \%$, possibly slippery, occasional steep rolls
- Roof bolts on $4 \mathrm{ft} \times 5 \mathrm{ft}$ to $5 \mathrm{ft}$ patterns with long bolts (6 $\mathrm{ft}$ to $10 \mathrm{ft}$ ) infrequent minor falls
o Occasional methane build-ups with properly designed ventilation system
- Coal easily cut, partings to 1 -ft thick that may degrade performance of winning machine, other impurities occasionaliy encountered, infrequent discontinuities
- Moderate seam depth - 400 to $800 \mathrm{ft}$
- Drainage water collects in pools to depths of 6 in., pools sporadically located, occasional need for sumps

LONGWALL PRODUCTION: Same references as LONGWALL PRODUCTION, IDEAL CONDITIONS.

- 6-ft seam

o Weak shale or hard fireclay floor which adversely impacts conveyor and support advance when it softens from water presence, supports may punch into floor if roof does not cave properly or where roof is considered heavy, grades to $7 \%$, possibly slippery, occasional steep rolls

- Roof does not always cave directly behind supports, infrequent cavities over supports, minor caves along face and in gateroads

o Occasional methane build-ups with properly designed ventilation system

- Easily cut coal with partings to 1-ft thick that degrade performance of winning machine, occasional impurities, interfaces are transitional, infrequent discontinuities

- Moderate seam depth -400 to $800 \mathrm{ft}$

- Drainage water collects in pools to depths of 6 in., occasional need for sump in gateroads 
PANEL DEVELOPMENT:

SHORTWALL PRODUCTION:
Same as LONGWALL, IDEAL CONDITIONS description. Developed from information in two references.
1. Kuti, J., as before
2. Stefanko, R., as before
o 6-ft seam
- Floor is hard, stable, and level; sandstone, hard fireclay or shale
- Roof rock stays in place after exposure; no cavities or caving at face; roof interface is definite, no transition; immediate caving at rear of supports
- No methane build-ups at face with minimum ventilation requirements ( $3000 \mathrm{cfm}$ )
- Coal is cut cleanly and easily by winning machine; no face sloughing; no partings, impurities, or discontinuities
- Moderate seam depth - 400 to $800 \mathrm{ft}$
- Drainage water dampens bottom; no standing water; no interference with support advance or equipment movement

PANEL DEVELOPMENT:

SHORTWALL PRODUCTION
Same as LONGWALL, AVERAGE CONDITIONS description. Same references as SHORTWALL PRODUCTION, IDEAL CONDITIONS.

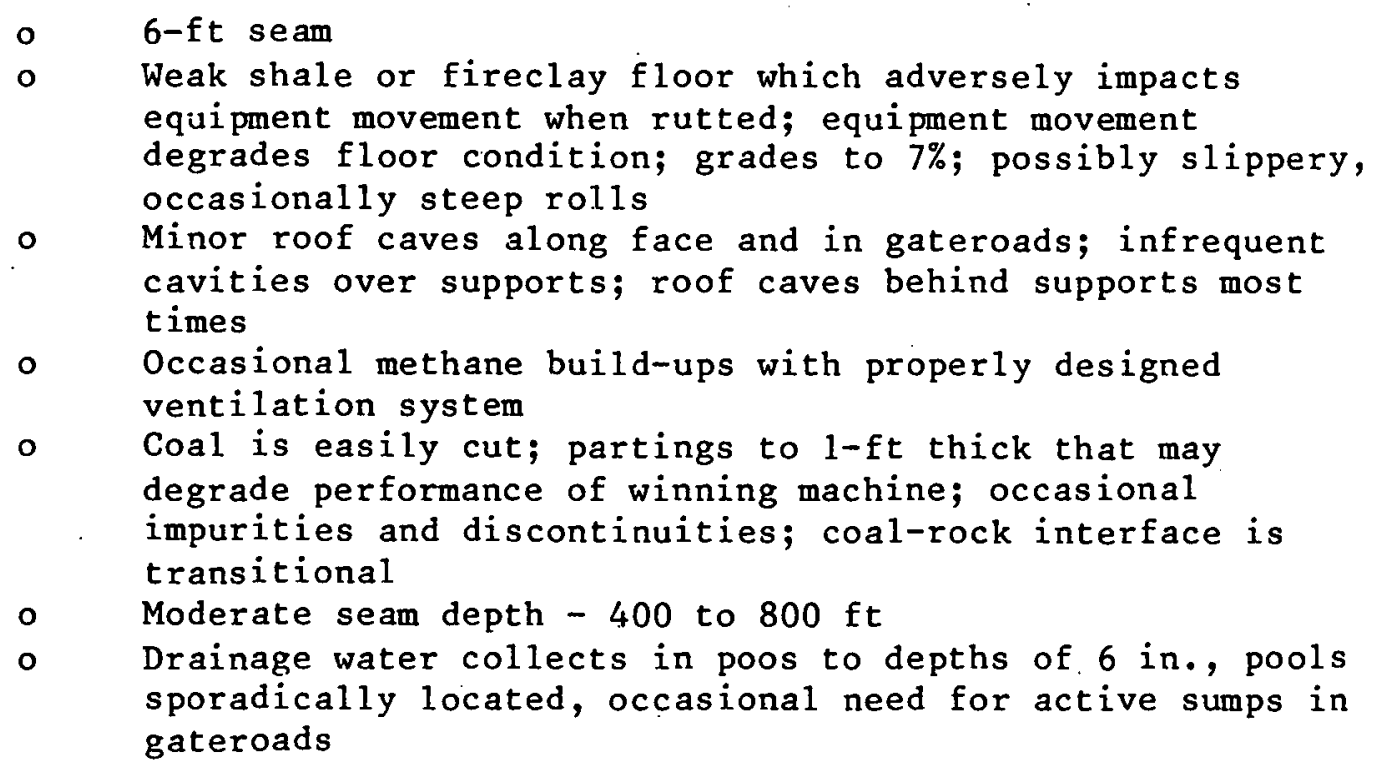

ROOM-AND-PILLAR

Conditions descriptions correspond to those used for longwall and shortwall panel development. 


\section{APPENDIX B}

PRODUCTION ANALYSIS

The purpose of Appendix B, Production Analysis is to present the approach and calculations used to determine productivity in terms of raw tons per machine-shift for the systems selected in the moving baseline study. Initially, the available productive time for all study cases is established. Secondly, the information and sources of that information used to estimate the system availabilities for the study are identified. The calculations that produce the availabilities are shown also. Finally, the available productive time and system availabilities are combined with appropriate calculations to determine the system productivities. 
THIS PAGE

\section{WAS INTENTIONALLY LEFT BLANK}


CONTENTS

I. AVAILABLE PRODUCTIVE TIME

II. SYSTEM AVAILABILITY

III. TONS PER MACHINE-SHIFT

A. 1980 Longwall and Shortwall Cases --

B. 2000 Longwall and Shortwal1 Panel Development -- - - - B-13

C. 1980 Longwal1 Production

D. 2000 Longwal1 Production

E. 1980 Shortwal1 Production - B-25

F. 2000 Shortwall Production

G. 1980 Room-and-Pillar

H. 2000 Room-and-Pillar 
THIS PAGE

WAS INTENTIONALLY

LEFT BLANK 


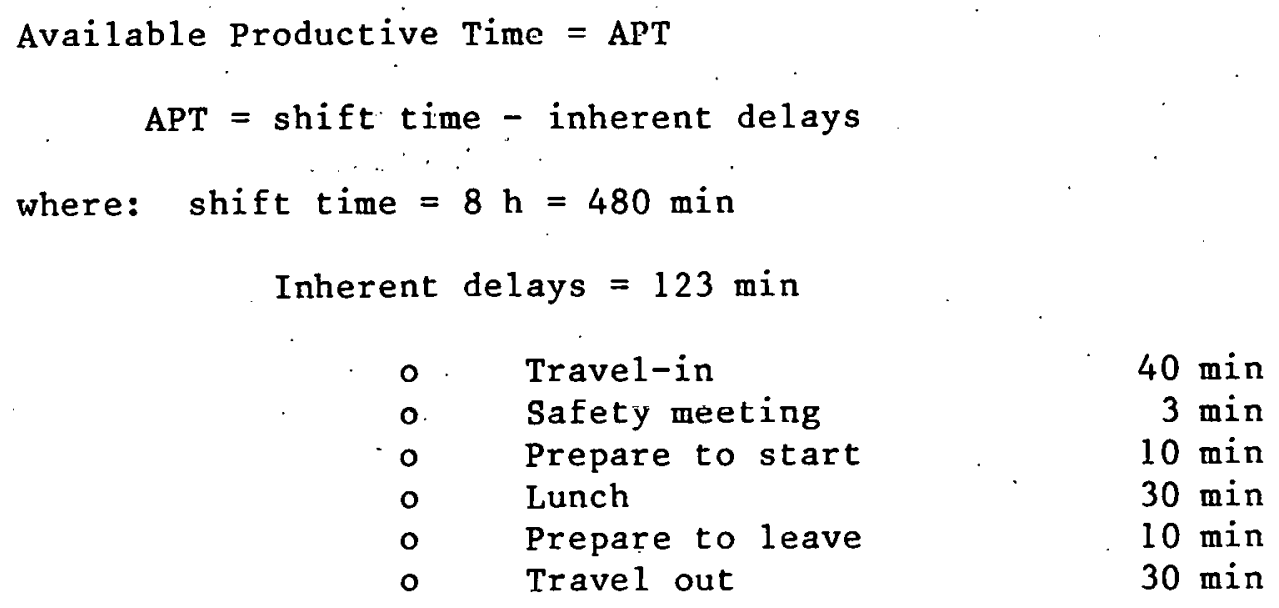

$\mathrm{APT}=480-123=357 \mathrm{~min}$

This value is used for all cases.

\section{SYSTEM AVAILABILITY}

$A=\frac{\text { net work time }}{\mathrm{APT}}=\frac{\mathrm{NWT}}{\mathrm{APT}}$

NWT = APT - other delays

Other delays: For average conditions cases, other delays include maintenance time, unexpected operational delays, mine-environment-related delays, and human-related delays.

For ideal conditions cases, the delays considered directly related to the mine environment were factored out.

In most cases, the values for NWT and APT were developed from actual operational data found in publications. 


\section{CONTINUOUS ROOM-AND-PILLAR CASES}

(Also applies to longwall and shortwall panel development cases)

Information for availability was extracted from: Frants, R. L., and R. H. King, Study of the Human Factor Aspects of an Automated Continuous Mining System, Final Report USBM Grant No. S0144115, March 1977.

$$
\begin{aligned}
& \text { Shift time }=480 \text { min } \\
& \text { APT }=320 \text { minutes } \\
& \text { Delays: } \\
& \text { Average conditions }=160 \mathrm{~min} \\
& \text { Ideal conditions }=120 \mathrm{~min} \\
& \mathrm{NWT}_{a}=160 \text { min } \\
& \mathrm{NWT}_{i}=200 \text { min } \\
& \mathrm{A}_{\mathrm{a}}=\frac{\mathrm{NWT}_{\mathrm{a}}}{\mathrm{APT}}=\frac{160}{320}=0.50 \\
& \mathrm{~A}_{i}=\frac{\mathrm{NWT}_{i}}{\mathrm{APT}}=\frac{200}{320}=0.63
\end{aligned}
$$


Information for availability was extracted from:

1. Herhal, A. J., et a1., Longwall Conveyor System Study, Final Report, Contract No. U.S. DOE ET-77-C-01 8915(2), June 1978.

2. Curry, K. C., et al., Longwall Mine Availability and Delay Analysis, Jet Propulsion Laboratory Report No. 5030-46, December 1976.

$$
\begin{aligned}
& \mathrm{APT}=517,725 \mathrm{~min} \\
& \mathrm{NWT}_{a}=292,143 \mathrm{~min} \\
& \mathrm{NWT}_{i}=332,678 \mathrm{~min} \\
& \mathrm{~A}_{\mathrm{a}}=\frac{\mathrm{NWT}_{\mathrm{a}}}{\mathrm{APT}}=\frac{292,143}{517,725}=0.56 \\
& \mathrm{~A}_{i}=\frac{\mathrm{NWT}_{i}}{\mathrm{APT}}=\frac{332,678}{517,725}=0.64
\end{aligned}
$$

SHORTWALL CASES

Information for availability was extracted from Curry, K. C., et al., Shortwall Mine Availability and Delay Analysis, JPL Internal Report No. 5030-47, December 1976.

$$
\begin{aligned}
& \mathrm{APT}=128,505 \mathrm{~min} \\
& \mathrm{NWT}_{a}=77,205 \mathrm{~min} \\
& \mathrm{NWT}_{i}=84,770 \mathrm{~min} \\
& \mathrm{~A}_{\mathrm{a}}=\frac{\mathrm{NWT}_{a}}{\mathrm{APT}}=\frac{77,205}{128,505}=0.60 \\
& \mathrm{~A}_{i}=\frac{\mathrm{NWT}}{\mathrm{APT}}=\frac{84,770}{128,505}=0.66
\end{aligned}
$$


A. 1980 LONGWALL AND SHORTWALL CASES

TONS PER MACHINE-SHIFT

1980 LONGWALL AND SHORTWALL PANEL DEVELOPMENT

IDEAL CONDITIONS

Cycle time: C

- One sump cycle

- Sump in $\frac{1}{2}$ drum diameter (18 in.) at $17 \mathrm{fpm}=\overline{0.088}$

- Shear down $36 \mathrm{in}$. at $34 \mathrm{fpm}$

$=0.088$

- Trim floor 18 in. at $17 \mathrm{fpm}$

$=0.088$

- Reposition drum 36 in. at $34 \mathrm{fpm}$

$=0.088$

TOTAL $=\frac{0.088}{0.352} \approx$

$0.35 \mathrm{~min}$

- One 40-ft lift cycle

- 20-ft advance, $20 \mathrm{ft} \times(0.35 \mathrm{~min} / 1.5 \mathrm{ft})=\overline{4.67}$

- Reposition: move $60 \mathrm{ft}$ at $60 \mathrm{fpm}=1.00$

- 30-ft advance, $30 \mathrm{ft} x(0.35 \mathrm{~min} / 1.5 \mathrm{ft})=7.00$

- Reposition: move $30 \mathrm{ft}$ at $60 \mathrm{fpm}=0.50$

- 20-ft advance $\quad=4.67$

- Reposition: move $30 \mathrm{ft}$ at $60 \mathrm{fpm}=0.50$

- 10-ft advance

$=2.33$

- Move to another face, amortized average place-change distance of $211 \mathrm{ft}$ per 1 ift; $211 \mathrm{ft}$ at $60 \mathrm{fpm}$ TOTAL $=\frac{3.50}{24.17} \mathrm{~min}$

- Amortized section move-up time per $40 \mathrm{ft}$ lift

- 10 lifts per move-up

- $1 \mathrm{~h}$ to accomplish a move-up

- 6.0 min per lift

- Cycle time per 40-ft 1 ift

$24.17 \mathrm{~min}+6.0 \mathrm{~min}=30.17 \mathrm{~min}$

Tons per cycle: T
- 10 lifts per move
- Total tons per move
- 1927.8 tons
- Average tons per lift
- 192.8 tons

Shift production: TPMS

$$
\begin{aligned}
\text { Tons per machine shift }=\frac{\mathrm{APT} \cdot \mathrm{A} \cdot \mathrm{T}}{\mathrm{C}} \\
-\mathrm{APT}=357 \mathrm{~min} \text { per machine-shift } \\
-\mathrm{A}=0.63 \text { tons per cycle } \\
-\mathrm{T}=192.8 \text { per cycle } \\
-\mathrm{C}=30.17 \mathrm{~min} \text { per } \\
\text { TPMS }=\frac{357 \times 0.63 \times 192.8}{30.17}=1437.28(1440)
\end{aligned}
$$




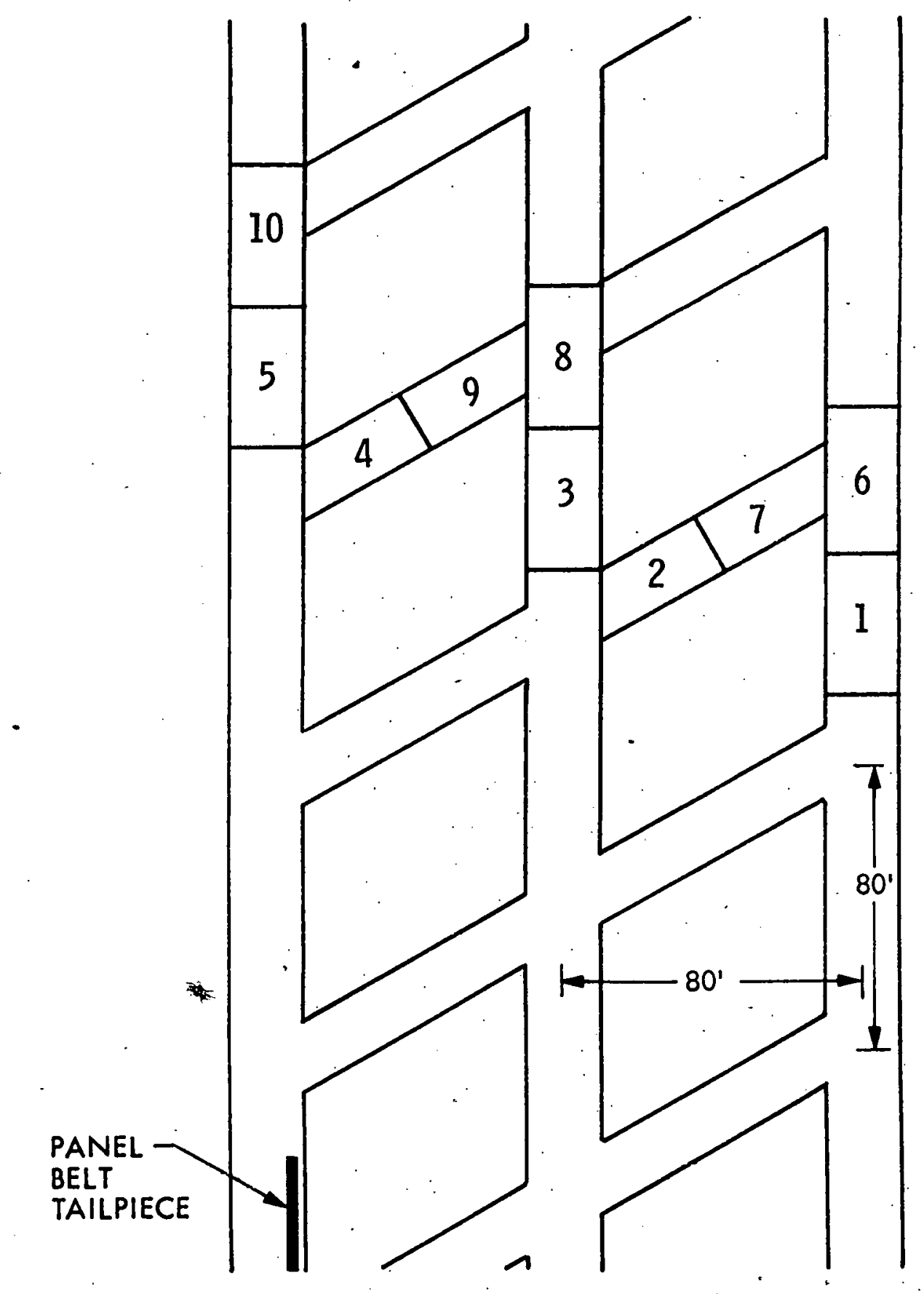

Figure B-1. Lift Sequence for 1980 Longwail and Shortwall Panel Development in Ideal Conditions 
AVERAGE CONDITIONS

Cycle time: C

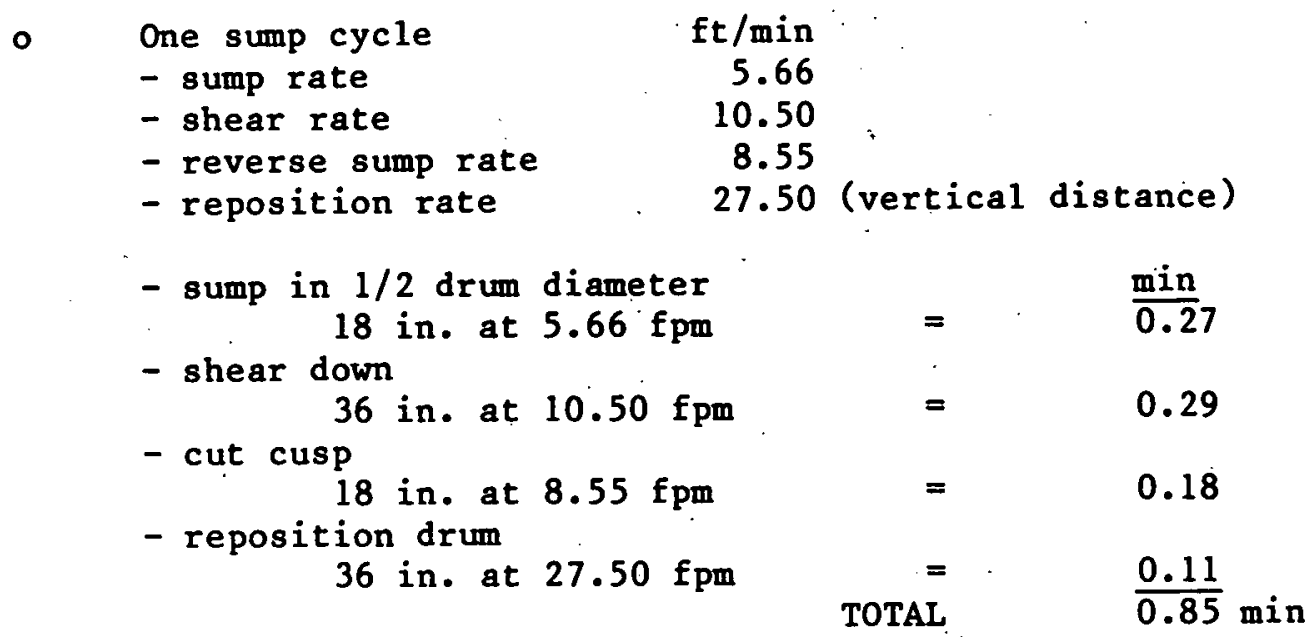

- One 20-ft long lift cycle

- constrained by allowable roof span for mining conditions selected

- 20-ft advance $20 \mathrm{ft} \times \frac{0.85 \mathrm{~min}}{1.5 \mathrm{~min}}=\frac{\min }{11.33}$

- reposition move $60 \mathrm{ft}$ at $30 \mathrm{fpm}=2.00$ (average case tram speed assumed to be $1 / 2$ ideal case)

- 20-ft advance

- place-change - average distance of $255.4 \mathrm{ft}$ per $20-\mathrm{ft} 1 \mathrm{ift}$ $255.4 \mathrm{ft}$ at $30 \mathrm{fpm}$

$\begin{array}{cr}= & \frac{8.50}{3.17}\end{array}$

- Amortized section move-up time per 20-ft 1 ift

- 20 lifts per move

- $1.5 \mathrm{~h}$ to accomplish move

- $4.50 \mathrm{~min}$ per lift

- Total cycle time per 20-ft lift $33.17 \mathrm{~min}+4.50 \mathrm{~min}$ $=\quad 37.67 \mathrm{~min}$

Tons per cycle: T

- 20 lifts per move

- Total tons per move

- 1927.8 tons

- Average tons per lift

- 96.39 tons 
Shift production: TPMS

- Tons per machine shift $=\frac{\mathrm{APT} \cdot \mathrm{A} \cdot \mathrm{T}}{\mathrm{C}}$

- Tons per machine-shift $=\mathrm{C}$

- APT $=357$ min per machine-shift

- $A=0.50$

- $T=96.39$ tons per cycle

- $C=37.67$ min per cycle

TPMS $=\frac{357 \times 0.50 \times 96.39}{37.67}$

$=456.75(460)$ 


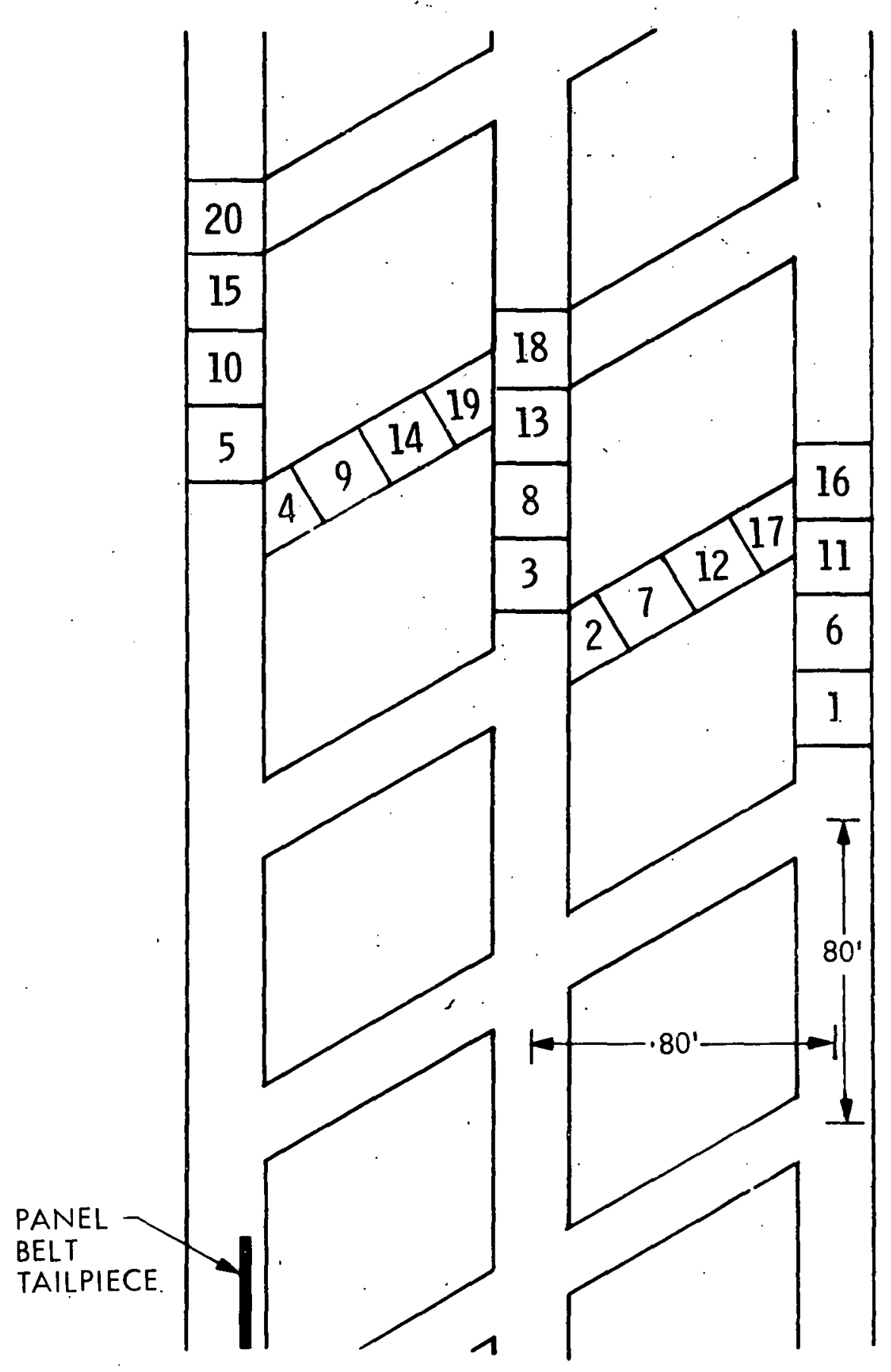

Figure B-2. Lift Sequence for 1980 Longwall and Shortwall Pane1 Development in Average Conditions 
IDEAL CONDITIONS

Cycle time: $\quad C$

- One sump cycle

- same as 1980 case

$-0.35 \mathrm{~min}$ per $1.5 \mathrm{ft}$ lift

- One lift

- 20-ft advance

- reposition: $60 \mathrm{ft}$ at $60 \mathrm{fpm}$

$\min$

- 30-ft advance

- reposition: $30 \mathrm{ft}$ at $60 \mathrm{fpm}$

- 20-ft advance

- reposition: $60 \mathrm{ft}$ at $60 \mathrm{fpm}$

- 20-ft advance

- reposition: $30 \mathrm{ft}$ at $60 \mathrm{fpm}$

- $20 \mathrm{ft}$ advamce

- reposition: $30 \mathrm{ft}$ at $60 \mathrm{fpm}$.

- 20-ft advance =

- reposition: $30 \mathrm{ft}$ at $60 \mathrm{fpm}=0.50$

- 20-ft advance $=4.67$

- reposition: $30 \mathrm{ft}$ at $60 \mathrm{fpm}=0.50$

- 10-ft advance = 2.33

- place-change, average move distance of $238.34 \mathrm{ft}$

$238.37 \mathrm{ft}$ at $60 \mathrm{fpm}$

TOTAL $\quad 45.32 \mathrm{~min}$

- Amortized section move-up time per $80-\mathrm{ft}$ lift

- $1.0 \mathrm{~h}$ to accomplish

- 5 lifts per move

$-12.0 \mathrm{~min}$ per lift

- Cycle time per $80-\mathrm{ft}$ lift

$45.30 \mathrm{~min}+12.0 \mathrm{~min}=57.30 \mathrm{~min}$

Tons per cycle: T

$\begin{array}{ll}\circ & 51 \text { lifts per move } \\ \circ & 1927.8 \text { tons per move } \\ \circ & 385.56 \text { tons per cycle }\end{array}$

Shift production: TPMS

- Tons per machine-shift $=\frac{\mathrm{APT} \cdot \mathrm{A} \cdot \mathrm{T}}{\mathrm{C}}$

- APT $=357$ min per machine-shift

$-\mathrm{A}=0.63$

- $\mathrm{T}=385.56$ tons per cycle

$-\mathrm{C}=57.32 \mathrm{~min}$ per cycle

TPMS $=\frac{357 \times 0.63 \times 385.56}{57.32}=1512.85 \quad(1510)$ 


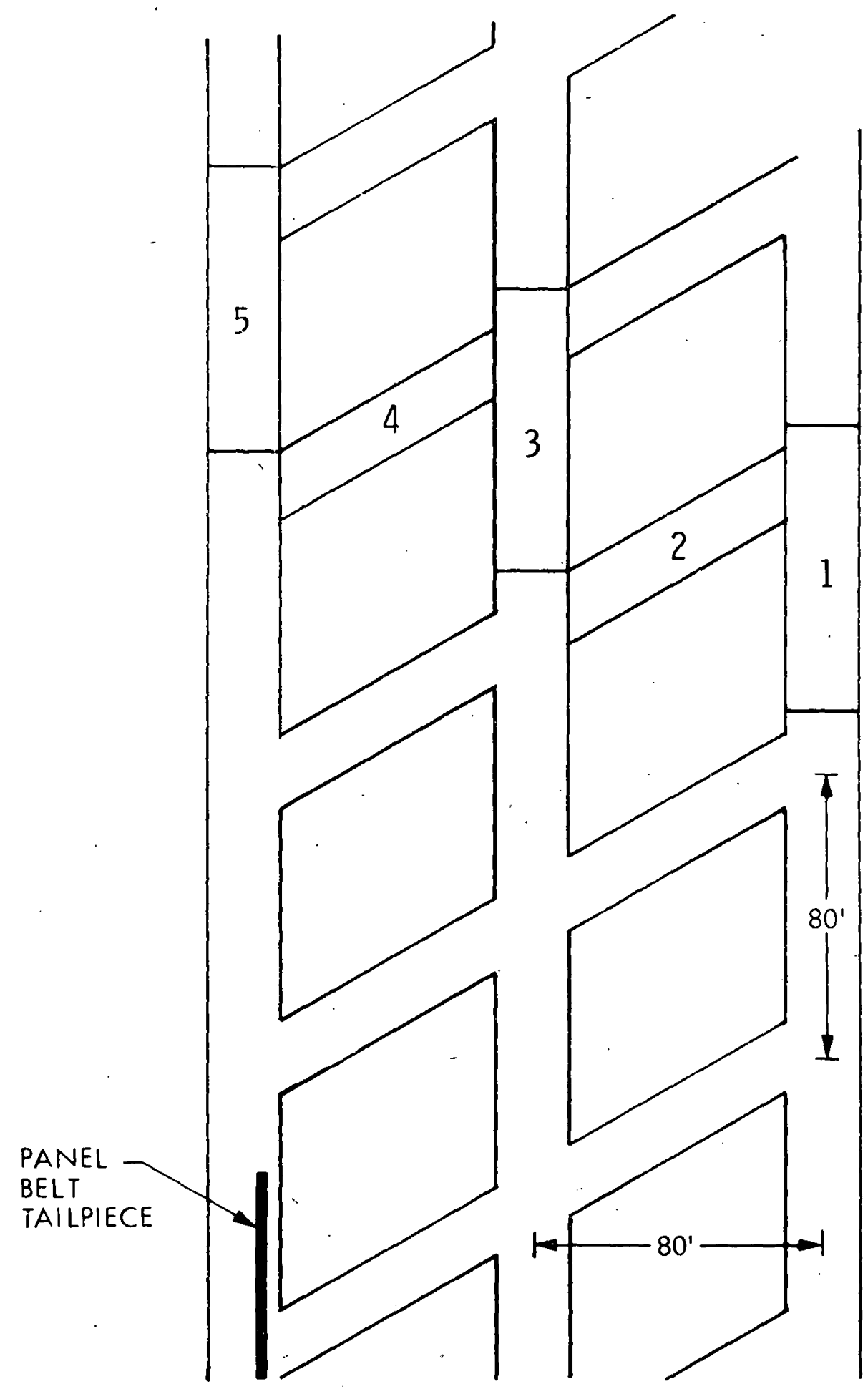

Figure B-3. Lift Sequence for 2000 Longwall and Shortwall Panel Development in Ideal and Average Conditions 
AVERAGE CONDITIONS

Cycle time: C

- One sump cycle

- same as 1980 case

$-0.85 \mathrm{~min}$ per $1.5 \mathrm{ft}$ lift

- One 80-ft lift

- 20-ft advance

- reposition $60 \mathrm{ft}$ at $30 \mathrm{fpm}$

- 30-ft advance

- reposition $30 \mathrm{ft}$ at $30 \mathrm{fpm}$

- 20-ft advance

- reposition $30 \mathrm{ft}$ at $30 \mathrm{fpm}$

- 20-ft advance

- reposition $30 \mathrm{ft}$ at $30 \mathrm{fpm}$

- 20-ft advance

- reposition $30 \mathrm{ft}$ at $30 \mathrm{fpm}$

- 20-ft advance

- reposition $30 \mathrm{ft}$ at $30 \mathrm{fpm}$

- 20-ft advance

- reposition $30 \mathrm{ft}$ at $30 \mathrm{fpm}$

- 10-ft advance

- place-change, average move distance $239.34 \mathrm{ft}$ at $30 \mathrm{fpm}$

TOTAL

$\frac{\min }{1.33}$

$1 \overline{1.33}$

2.00

17.00

1.00

11.33

1.00

11.33

1.00

11.33

1.00

11.33

1.00

11.33

1.00

5.67

$\underline{7.94}$

$10 \overline{6.59} \mathrm{~min}$

- Amortized section move-up time per $80-\mathrm{ft}$ lift

- 5 lifts per move

- $1.5 \mathrm{~h}$ to accomplish move

- $18 \mathrm{~min}$ per lift

- Cycle time per 80-ft lift

$106.59 \mathrm{~min}+18.0 \mathrm{~min}=124.59 \mathrm{~min}$

Tons per cycle: T

- 51 ifts per move

- 1927.8 tons per move

- $\quad 385.56$ tons per cycle

Shift production: TPMS

- Tons per machine-shift $=\frac{\mathrm{APT} \cdot \mathrm{A} \cdot \mathrm{T}}{\mathrm{C}}$

- APT $=357$ min per machine-shift

$-A=0.50$

- $\mathrm{T}=385.56$ tons per cycle

- C $=124.59 \mathrm{~min}$ per cycle

$\mathrm{TPMS}=\frac{357 \times 0.50 \times 385.56}{124.59}=552.4$ 


\section{1980 LONGWALL PRODUCTION}

\section{IDEAL CONDITIONS}

Cycle time: $C$

$$
\begin{aligned}
& \text { - Steps as per attached figure } \\
& \text { 1. Shearer in position for sump } \\
& \text { 2. Shearer sumped into face and travels to } \\
& \text { tailgate, conveyor snake finished at headgate } \\
& \text { - cut travel }=400 \mathrm{ft}
\end{aligned}
$$

5. Set picks, range drums, and reverse loading

$$
\text { devices and shearer } 7.0 \mathrm{~min}
$$

6. Shearer finishes cut at headgate, then flits to sump position

- cut travel $=20 \mathrm{ft}$

- flit trave $1=80 \mathrm{ft}$

TOTAL :

$$
\begin{aligned}
& \text { cut travel }=590 \mathrm{ft} \\
& \text { flit trave } 1=410 \mathrm{ft}
\end{aligned} \quad \text { } \quad \text { m.0 min }
$$

- Amortized headgate move time

- 0.50 min per $\mathrm{ft}$ of advance

- each cycle provides an advance of $33 \mathrm{in} .(2.75 \mathrm{ft})$

- amortized headgate move time $=1.38 \mathrm{~min}$

$$
2.75 \mathrm{ft} \times 0.50 \frac{\mathrm{min}}{\mathrm{ft}}
$$

- Cycle time per 33-in. web

- $590 \mathrm{ft}$ of cut travel at $30 \mathrm{fpm}=\frac{1 \overline{\mathrm{pm}}}{19.67}$

$\begin{array}{ll}-410 \mathrm{ft} \text { of flit travel at } 50 \mathrm{fpm}= & \mathbf{8 . 2 0}\end{array}$

- turn-arounds, etc. $=9.00$

- amortized headgate move time. $=\underline{1.38}$

TOTAL: $\quad 3 \overline{8.25} \mathrm{~min}$

Tons per cycle: $T$

- One cycle: one pass across entire face

- Dimensions: 500-ft long $\times$ 6-ft high $\times 2.75-\mathrm{ft}$ wide

- Tons : 350.63

Shift production: TPMS

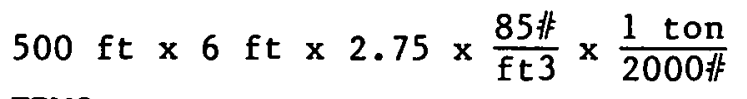

- Tons per machine-shift $=\frac{\text { APT } \cdot A \cdot T}{C}$

- APT $=357$ min per machine-shift

$-\mathrm{A}=0.64$

- $T=350.63$ tons per cycle

$-\mathrm{C}=38.25 \mathrm{~min}$ per cycle

TPMS $=\frac{357 \times 0.64 \times 350.63}{38.25}=2094.43$ 


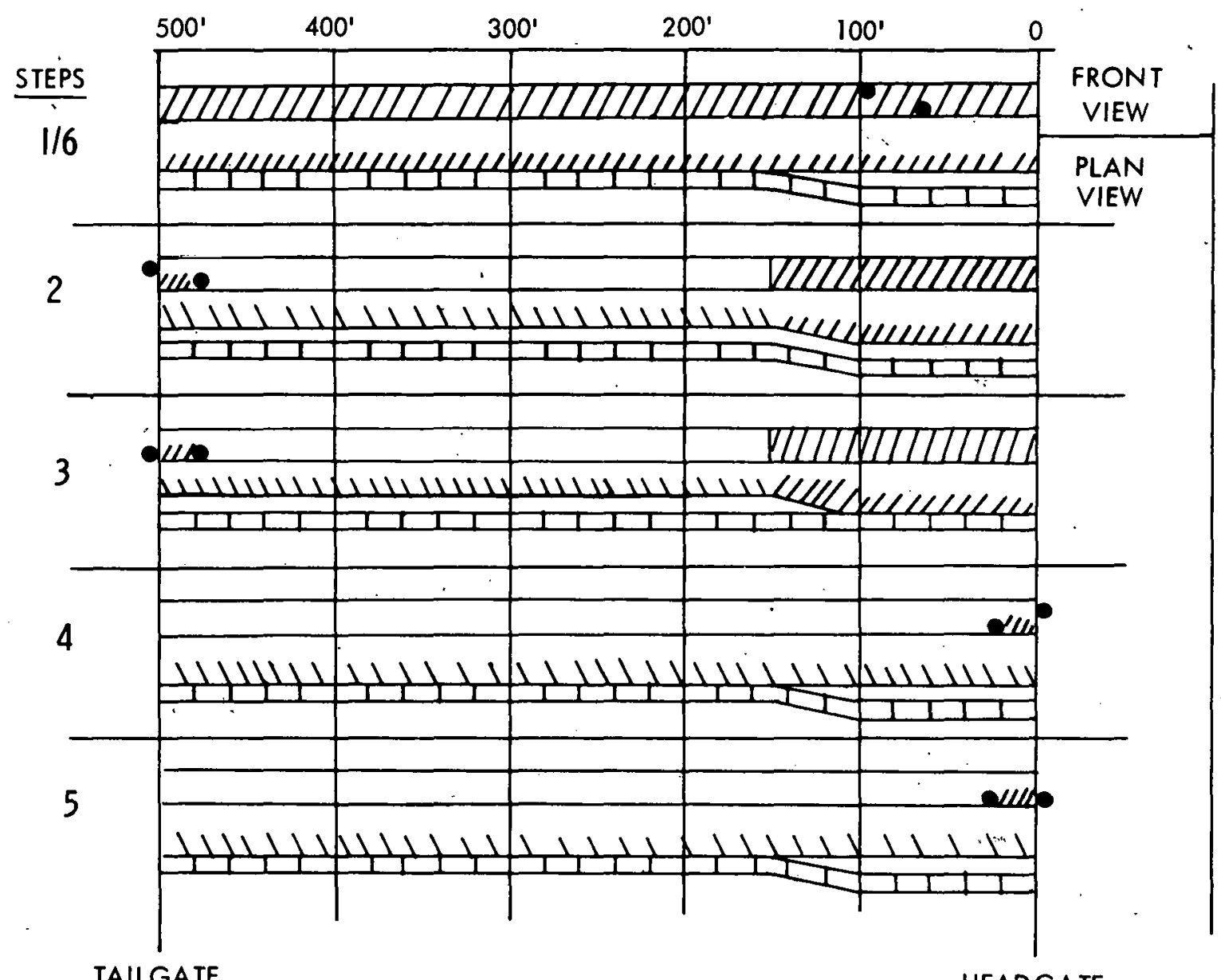

HEADGATE

- - Shearer dRUM position

DII - ARMORED FACE CONVEYOR POSITION

Figure B-4. Sequence of Steps for Shearer and Conveyor Movements During Removal of One Web With Half-face Operation 
AVERAGE CONDITIONS

Cycle time: $\mathrm{C}$

- Same steps as "Ideal Case"

Total: Cut travel $=590 \mathrm{ft}$

F1it trave $1=410 \mathrm{ft}$

Turn-arounds, etc. $=9.0 \mathrm{~min}$

- Amortized headgate move time

- $0.64 \mathrm{~min} / \mathrm{ft}$ of advance

- each cycle provides an advance of $33 \mathrm{in} .(2.75 \mathrm{ft})$

- amortized headgate move time $=1.8 \mathrm{~min}$

$2.75 \mathrm{ft} \times \frac{0.64 \mathrm{~min}}{\mathrm{ft}}$

- Cycle time per 33-in. web

- $590 \mathrm{ft}$ of cut travel at $11 \mathrm{fpm}=$

- $410 \mathrm{ft}$ of flit travel at $28 \mathrm{fpm}=14.6$

- turn-arounds, etc..... $=9.0$

- amortized headgate move $=\quad \cdot \frac{1.8}{79.0}$

TOTAL: $\quad \overline{79.0} \mathrm{~min}$

Tons per cycle: T

- Same as "Ideal Case"

o $\quad 350.63$ tons

Shift production: TPMS

- Tons per machine-shift $=\frac{\text { APT } \cdot A \cdot T}{C}$

- APT $=357$ min per machine-shift

$-A=0.56$

- $\mathrm{T}=350.63$ tons per cycle

$-\mathrm{C}=79.0 \mathrm{~min}$ per cycle

$\mathrm{TPMS}=\frac{357 \times 0.56 \times 350.63}{79.0}=887.32$ 
D. 2000 LONGWALL PRODUCTION

IDEAL CONDITIONS

Cycle time: C

- Steps as per attached figure

- The attached Gantt Chart illustrates that the headgate shearer cycle time is in fact the cycle time for both shearers because of overlaps.

1. Headgate shearer is ready for sump into face, tailgate shearer has finished turn around and cut, and starts flit back to mid-face, snake of tailgate section of AFC is started.

2. Headgate shearer sumps into face at $300 \mathrm{ft}$ and cuts to headgate cut travel: $300 \mathrm{ft}$ tailgate shearer follows into web, drums are ranged for its cut travel as conveyor snake is finished.

3. Headgate shearer drums ranged, picks checked, loading devices are reversed $\underline{7.0 \mathrm{~min}}$

4. Headgate shearer finished cut at gate, then flits to mid-face . cut travel: $30 \mathrm{ft}$ flit travel: $270 \mathrm{ft}$

tailgate shearer finished cut and starts turn-around at gate.

5. Headgate shearer drums ranged, loading devices reversed in preparation for next cut, snake of headgate conveyor section finished $2.0 \mathrm{~min}$ tailgate shearer finished turn-around and starts to finish cut. TOTAL : cut travel: $330 \mathrm{ft}$ fit travel: $270 \mathrm{ft}$ turn-arounds: $9.0 \mathrm{~min}$

- Amortized headgate move

- $0.50 \mathrm{~min} / \mathrm{ft}$ of advance

- each cycle provides $3 \mathrm{ft}$ of advance

- move time $=1.5$ min per cycle

- Cycle time per 3-ft web

- $330 \mathrm{ft}$ at $30 \mathrm{fpm}$

- $270 \mathrm{ft}$ at $50 \mathrm{fpm}$

- turn-around, etc.

- amortized headgate move

$\begin{array}{lr}= & \frac{\min }{1.0} \\ = & 5.4 \\ = & 9.0 \\ = & \frac{1.5}{26.9} \mathrm{~min}\end{array}$

Tons per cycle: T

- One cycle: 3-ft wide web across entire face

o Dimension: 3-ft wide $x$ 6-ft high $x$ 500-ft long

o Tons: 382.5 
Shift production: TPMS

- Tons per machine-shift $=\frac{\operatorname{APT} \cdot A \cdot T}{C}$

- APT $=357$ min per machine-shift

$-A=0.64$

$-\mathrm{T}=382.5$ tons per cycle

$-\mathrm{C}=26.9 \mathrm{~min}$ per cycle

TPMS : $=\frac{357 \times 0.64 \times 382.5}{26.9}=3248.83$

(3250) 

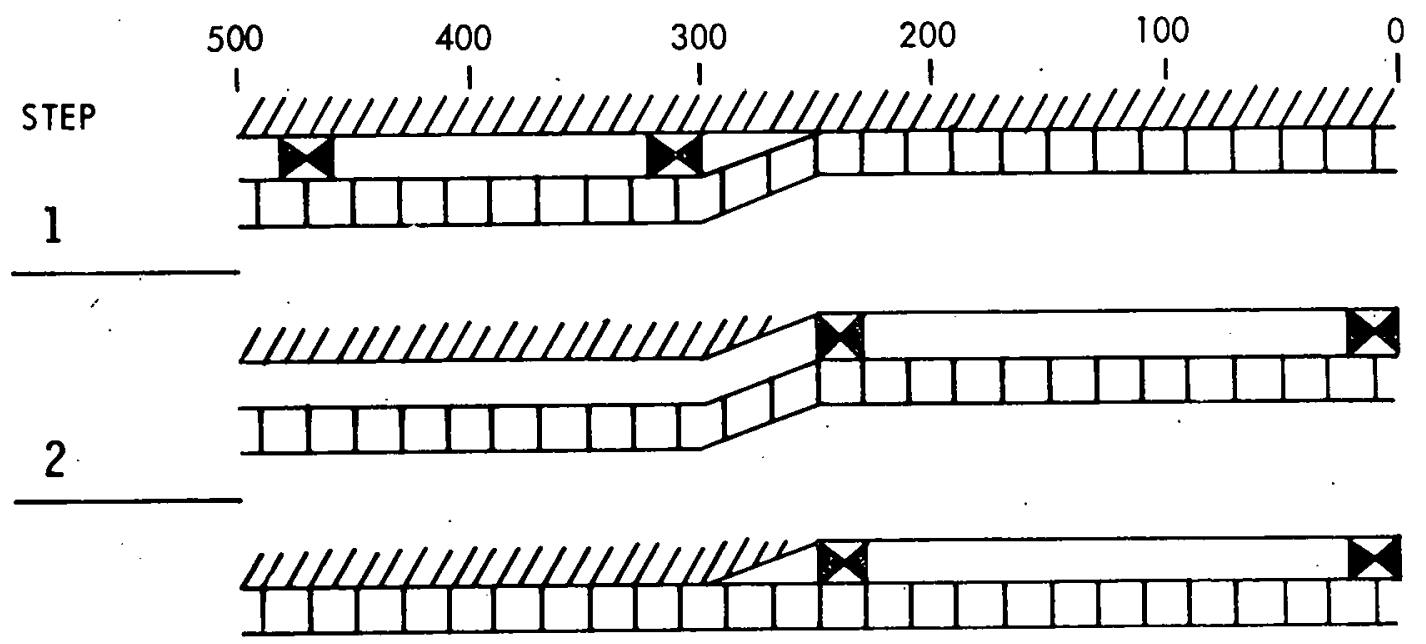

3

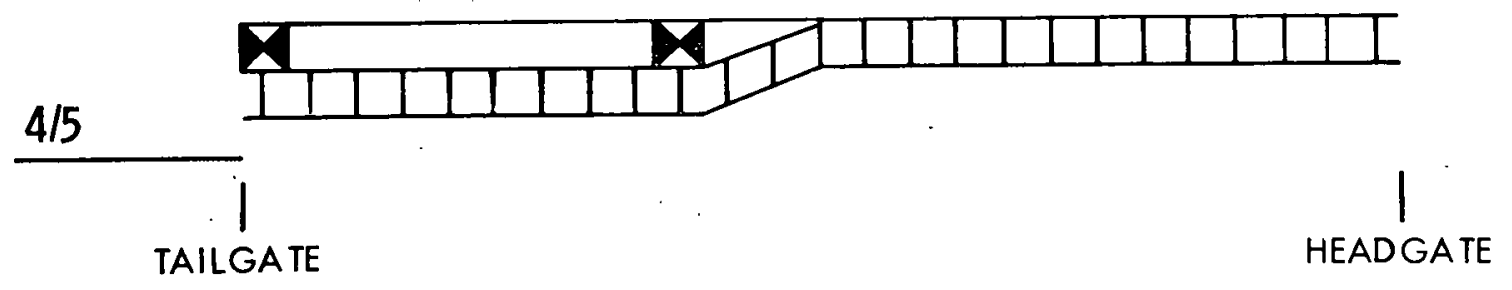

$\boldsymbol{\nabla}$ - SHEARERS
$\square \square$ - ARMORED FACE CONVEYOR

Figure B-5. Plan-view Illustrations of Cycle Steps for 2000 Longwall Systems 


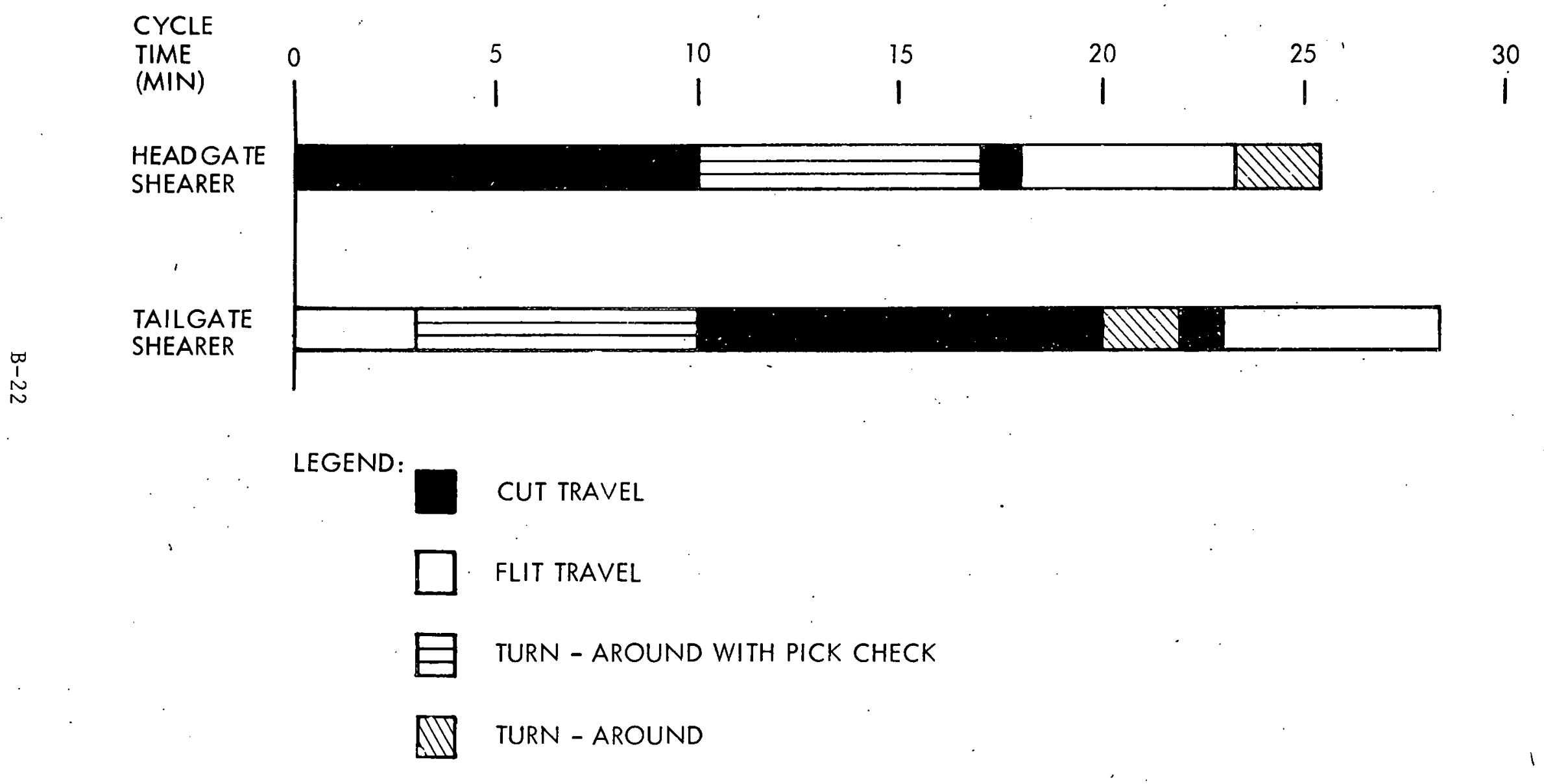

Figure B-6. Gantt Chart of Shearer Scheduling for 2000 Longwall System in Ideal Conditions 
AVERAGE CONDITIONS

Cycle time: C

- Same steps'as "Ideal Conditions" case

- The attached Gantt Chart shows that the shearers' cycle time is controlled by the sum of major cut travel time

- Each shearer travels $300 \mathrm{ft}$ during these periods

- Amortized headgate move

- $0.64 \mathrm{~min} / \mathrm{ft}$ of advance

- each. cycle provides $3 \mathrm{ft}$ of advance

- move time + $1.92 \mathrm{~min}$

$\circ$

Cycle time per 3-ft web

- $600 \mathrm{ft}$ of cut travel at $11 \mathrm{fpm}=\overline{54.55}$

- amortized headgate more

$=\quad 1.92$

TOTAL $\frac{1.92}{56.47} \mathrm{~min}$

Tons per cycle: $\mathrm{T}$

- Same as "Ideal Conditions" case
- 382.5 tons

Shift production: TPMS

- Tons per machine shift $=\frac{\text { APT } \cdot A \cdot T}{C}$

- APT $=357$ min per machine-shift

$-\mathrm{A}=0.56$

- $\mathrm{T}=382.5$ tons per cycle

- $C=56.47$ min per cycle

TPMS $=\frac{357 \times 0.56 \times 382.5}{56.47}=1354.27$ 


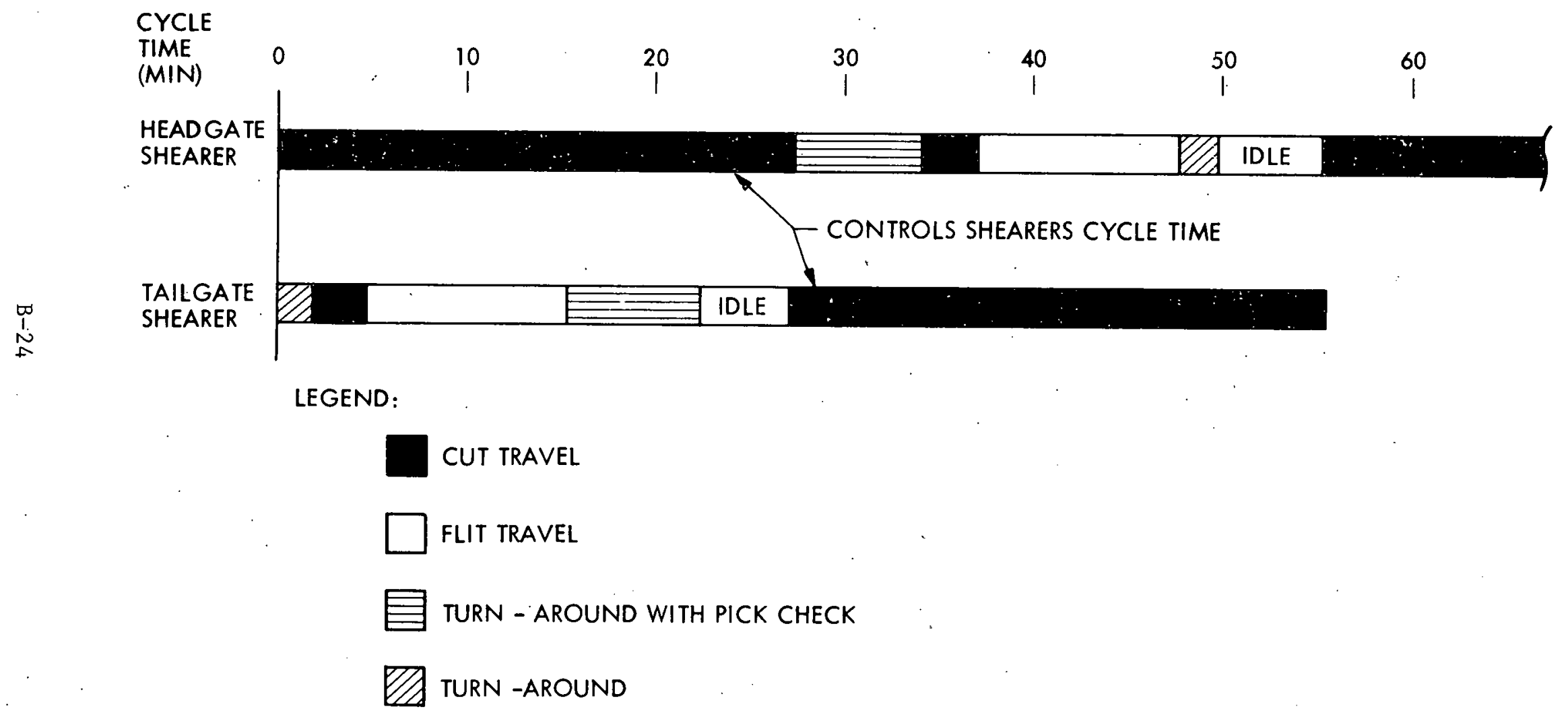

Figure B-7. Gantt Chart of Shearer Scheduling for 2000 Longwall System in Average Conditions 
IDEAL CONDITIONS

Cycle time: C

- One sump cycle

- same as 1980 Shortwall Development in "Ideal Conditions" case

- 0.35 min per $1.5 \mathrm{ft}$ advance

- One 180-ft lift across face

$-180 \mathrm{ft} \times \frac{0.35 \mathrm{~min}}{1.5 \mathrm{ft}}=42.0 \mathrm{~min}$

- First support advance

- supports advance $10 \mathrm{ft}$ behind continuous miner

- $10 \mathrm{ft}+$ machine length $(30 \mathrm{ft})$ is the amount of support advance required after machine starts its flit

$-40 \mathrm{ft}=8$ supports

- support advance cycle is $30 \mathrm{~s}$.

- $4.0 \mathrm{~min}$ of support advance before first guide rail advance is started

- Continuous miner flit

- under actual conditions, flit speed is 20 fpm

- assumed twice average condition speed for ideal - $40 \mathrm{fpm}$

- face is 180-ft long

- $20 \mathrm{ft}$ of clearance required in headgate (assumed)

$(180 \mathrm{ft}+20 \mathrm{ft}) / 40 \mathrm{fpm}=5.0 \mathrm{~min}$

- Guide rail advance

- two advances required, one after each support advance

- 15 s per ram

- 1 ram per 3 supports

- 13 rams $x 15 \mathrm{~s}$ per $\mathrm{ram}=3.25 \mathrm{~min}$

- Second support advance

- 40 supports

- 30 s per support

- 20 min to advance wall

- Amortized section move-up time per $10 \mathrm{ft}$ of advance

- one move every $80 \mathrm{ft}$

- 8 lifts ( $10 \mathrm{ft}$ each) every move

- $1 \mathrm{~h}$ to accomplish move

- 7.5 min per lift

- Cycle time per 10-ft wide lift

- face equipment cycle time is $72.5 \mathrm{~min}$ as per attached Gantt Chart

- face equipment cycle

- amortized move-up

$$
\begin{aligned}
& =\quad 7^{\frac{\min }{2.5}} \\
& =7.5 \\
& \text { TOTAL: } \quad \overline{80.0} \mathrm{~min}
\end{aligned}
$$


Tons per cycle: $T$

$$
\begin{aligned}
& \text { - One cycle: 10-ft wide lift across entire face } \\
& 0 \text { Dimensions: 180-ft long } \times 6 \mathrm{ft}-\mathrm{high} \times 10 \mathrm{ft} \text {-wide } \\
& \text { - Tons: } 459 \\
& \text { Shift production: TPMS }
\end{aligned}
$$

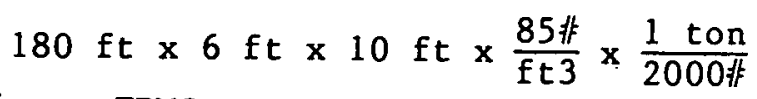

- Tons per machine-shift $=\frac{\mathrm{APT} \cdot \mathrm{A} \cdot \mathrm{T}}{\mathrm{C}}$

- APT $=357$ min per machine-shift

$-\mathrm{A}=0.66$

- $\mathrm{T}=459$ tons per cycle

- $\mathrm{C}=80.0 \mathrm{~min}$ per cycle

TPMS $=\frac{357 \times 0.66 \times 459}{80.0}=1351.87 \quad(1350)$ 


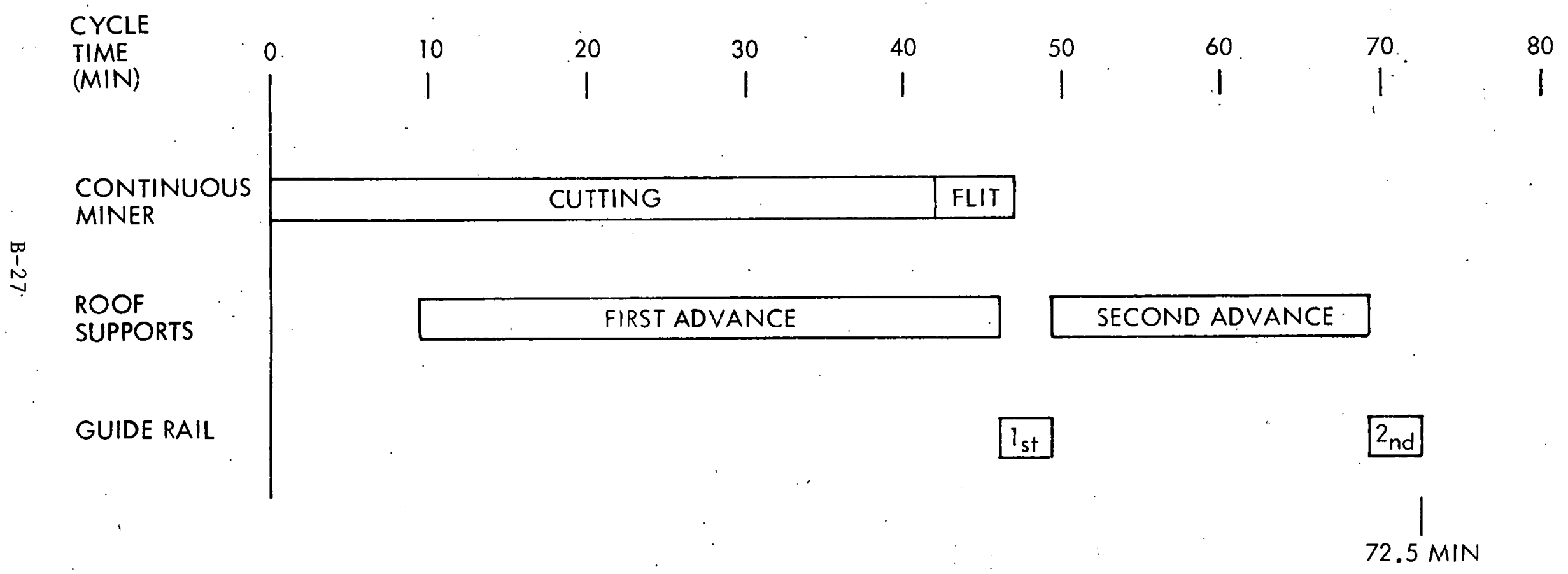

Figure B-8. Gantt Chart of Face Equipment Scheduling for 1980 Shortwall System in Ideal Conditions 
AVERAGE CONDITIONS

Cycle time: C

- One sump cycle

- same as 1980 shortwall development in "Average Conditions" case

- 0.85 min per $1.5-\mathrm{ft}$ advance

- One 180-ft lift across face

$180 \mathrm{ft} \times \frac{0.85 \mathrm{~min}}{1.5 \mathrm{ft}}=102.0 \mathrm{~min}$

- First support advance

- supports advance $10 \mathrm{ft}$ behind continuous miner

$-10 \mathrm{ft}+30 \mathrm{ft}$ (machine length)

$-40 \mathrm{ft}=8$ supports

- support advance cycle is $45 \mathrm{~s}$ for average conditions

- $6.0 \mathrm{~min}$ of support advance before first guide rail advance is started

- Continuous miner flit

- speed is $20 \mathrm{fpm}$

- distance is the same as "Ideal Conditions," $(180 \mathrm{ft}+20 \mathrm{ft}) / 20 \mathrm{fpm}=10.0 \mathrm{~min}$

- Guide rail advance

- two advances required, one after each support advance

- assumed guide rail advance rate in average conditions is twice that of ideal conditions

$3.25 \frac{\mathrm{min}}{\text { advance }} \times 2=6.5 \frac{\mathrm{min}}{\text { advance }}$

- Second support advance

- 40 supports

- 45 s per support

- 30 min to advance wall

- Amortized section move-up time per $10 \mathrm{ft}$ of advance

- one move every $80 \mathrm{ft}$

- 8 lifts every move

- $1.5 \mathrm{~h}$ to accomplish move

- 11.25 min per lift

- Cycle time per 10-ft wide lift

- face equipment cycle time per attached Gantt Chart

- face equipment cycle

$6 \frac{\min }{1.0}$

- amortized move-up

TOTAL

11.25

$\overline{172.25} \mathrm{~min}$

Tons per cycle: T

- same as "Ideal Conditions" case

- 459 tons per cycle 
Shift production: TPMS

- Tons per machine-shift $=\frac{\text { APT } \cdot A \cdot T}{C}$

- APT = 357 min per machine-shift

$-\mathrm{A}=0.60$

- $\mathrm{T}=459$ tons per cycle

$-C=172.25 \mathrm{~min}$ per cycle

PMS $=\frac{357 \times 0.60 \times 459}{172.25}=570.79 \quad(570)$

0

B-29 


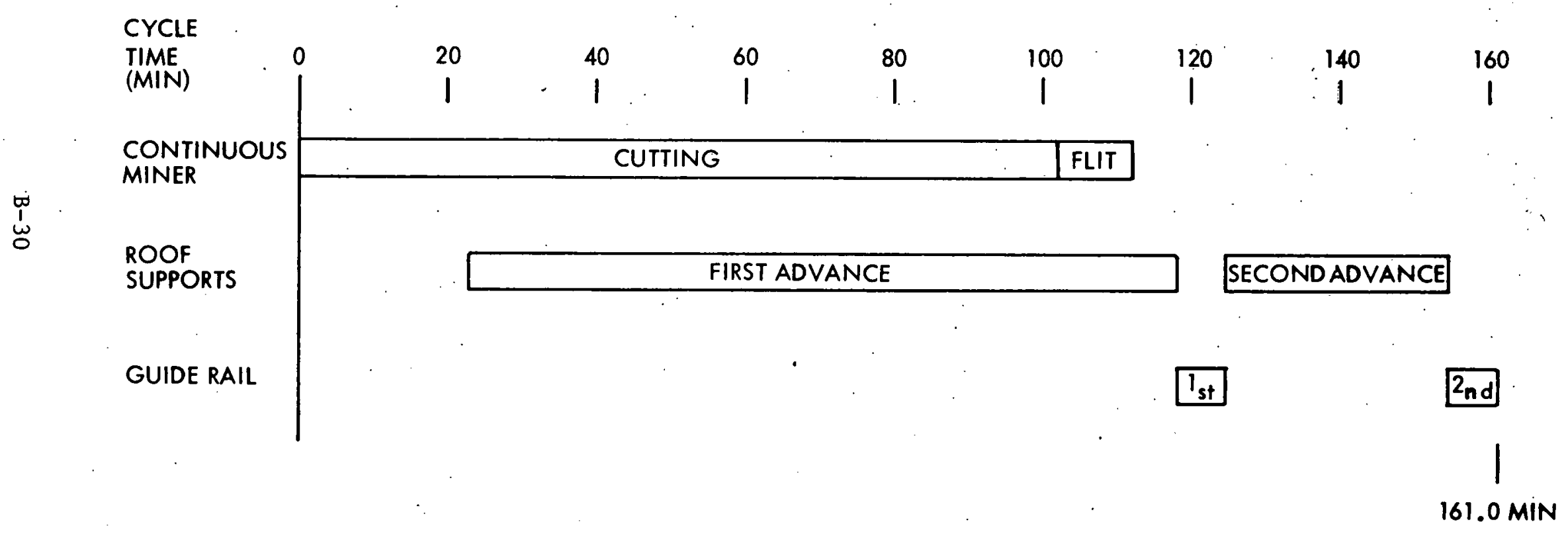

Figure B-9. Gantt Chart of Face Equipment Scheduling for 1980 Shortwall System in Average Conditions 
IDEAL CONDITIONS

Cycle time: C

- One sump cycle

- rates are the same, but cutter head is $4 \mathrm{ft}$ in diameter rather than 3 , therefore deeper sump

- sump head $2 \mathrm{ft}$ at $17 \mathrm{fpm}$

$\begin{array}{cl}= & \frac{\min }{0.12} \\ = & 0.06 \\ = & 0.12 \\ = & \underline{0.12} \\ \text { TOTAL } & \text { ‥42 } \mathrm{min}\end{array}$

- One 180-ft long lift across face

$-180 \mathrm{ft} \times \frac{0.42 \mathrm{~min}}{2 \mathrm{ft}}=37.80 \mathrm{~min}$

- Support advance

- supports advance $10 \mathrm{ft}$ behind continuous miner cut

- $10 \mathrm{ft}+$ machine length $(30 \mathrm{ft})$ is the amount of support advance required after machine starts its flit

$-40 \mathrm{ft}=8$ support

- support advance cycle is $10 \mathrm{~s}$

- 1.33 min of support advance before guide rail advance is started

- Continuous miner flit

- same speed and time as 1980 Shortwall, Ideal Conditions case

- $40 \mathrm{fpm}$ for $200 \mathrm{ft}$

- 5 min to flit

- Guide rail advance

- advance is started as miner flits and is finished as miner enters headgate

- Amortized section move-up time per $7 \mathrm{ft}$ of advance

- one move every $80 \mathrm{ft}$

- 11.43 lifts every move

- $1.0 \mathrm{~h}$ to accomplish move

- $5.25 \mathrm{~min}$ per $1 \mathrm{ift}$

- Cycle time per 7-ft wide lift

- face equipment cycle time as per attached Gantt Chart

- face equipment cycle

$$
\begin{aligned}
& =\frac{\min }{2.8} . \\
& =\frac{5.25}{48.05} \mathrm{~min}
\end{aligned}
$$

- amortized move-up

Tons per cycle: $T$

- One cycle: 7-ft wide lift across entire face

- Dimensions: 180-ft long $\times$ 6-ft high $\times$ 7-ft wide

o Tons: 321.3 
Shift production: TPMS

- Tons per machine-shift $=\frac{\mathrm{APT} \cdot \mathrm{A} \cdot \mathrm{T}}{\mathrm{C}}$

- APT = 357 min per machine-shift

$-A=0.66$

- $T=321.3$ tons per cycle

- $C=48.05$ min per cycle.

TPMS $=\frac{357 \times 0.66 \times 321.3}{48.05}=1575.54 \quad(1580)$ 


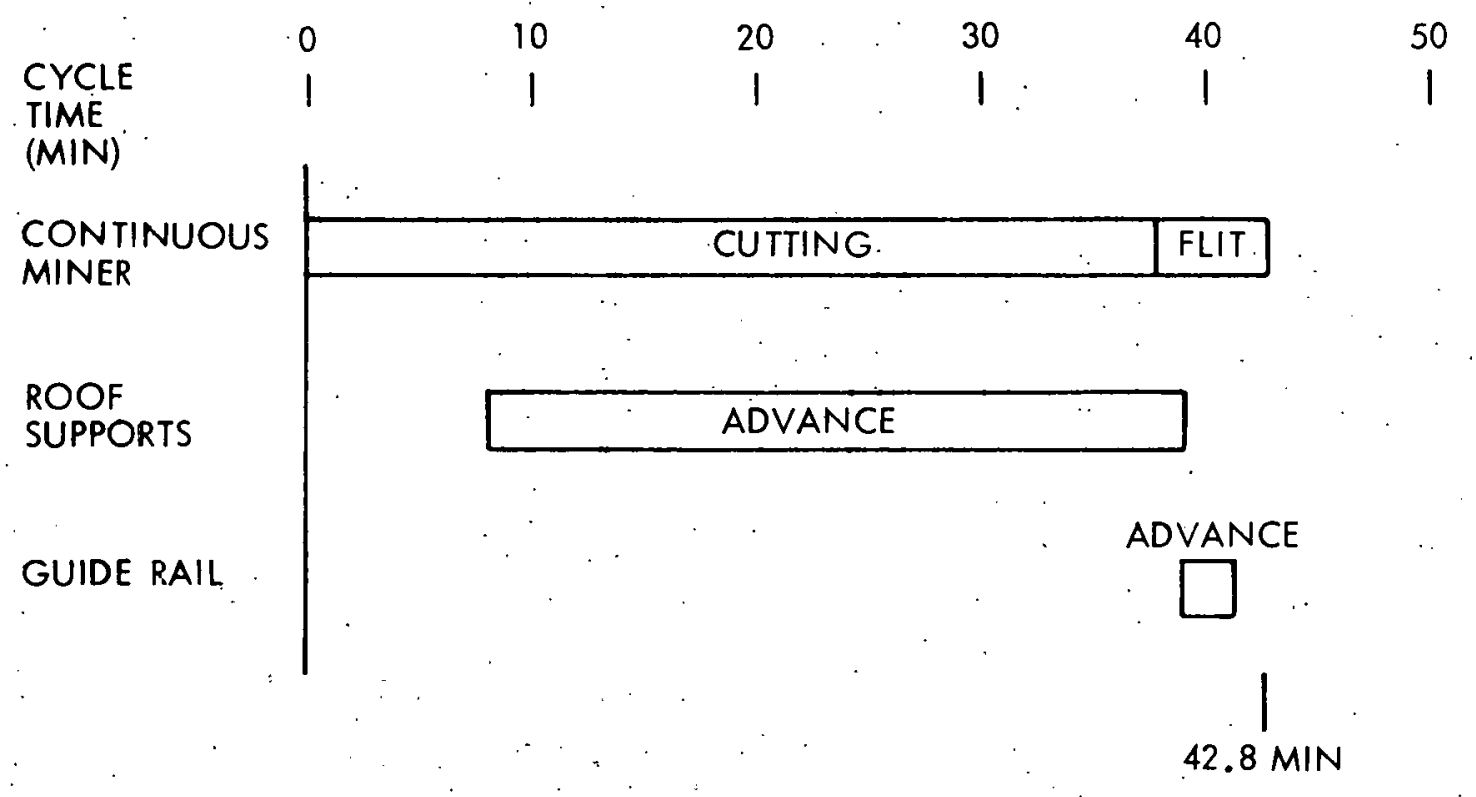

Figure B-10. Gantt Chart of Face Equipment Scheduling for 2000 - Shortwall System in Ideal Conditions 


\section{AVERAGE CONDITIONS}

Cycle time: C

- One sump cycle

- same rates as 1980 Shortwall Development, Average Conditions case

- sump 2 ft at $5.66 \mathrm{fpm}$

$\begin{array}{ll}= & \frac{\min }{0.35} \\ = & 0.19 \\ = & 0.23 \\ = & 0.07 \\ \text { TAL } & 0.84 \mathrm{~min}\end{array}$

- One 180-ft long lift across face

$-180 \mathrm{ft} \times \frac{0.84 \mathrm{~min}}{2 \mathrm{ft}}=75.60 \mathrm{~min}$

- Support advance

- supports advance $10 \mathrm{ft}$ behind continuous miner

- supports advance in average case assumed twice that of ideal case, $20 \mathrm{~s}$ per support

- 8 supports at $20 \mathrm{~s}$ each $=2.67 \mathrm{~min}$

- 2.67 min of support advance at tailgate before guide rail advance started

- Continuous miner flit

- $20 \mathrm{fpm}$ speed

- $200 \mathrm{ft}$ of trave1

- $200 \mathrm{ft}$ at $20 \mathrm{fpm}=10 \cdot \mathrm{min}$

- Guide rail advance

- advance is started as miner flits and is finished as miner enters headgate

- Amortized section move-up time per $7 \mathrm{ft}$ of advance

- one move every $80 \mathrm{ft}$

- 11.43 lifts every move

- 1.5.h to accomplish move

- 7.87 min per lift

- Cycle time per 7-ft wide lift

- face equipment cycle time as per attached Gantt Chart

- face equipment cycle

- amortized move-up

$\begin{aligned} \text { per attached Gantt Chart } & \begin{aligned} & \text { min } \\ &= 8 \frac{5.6}{5.6} \\ &= \frac{7.87}{93.47} \mathrm{~min}\end{aligned} \\ \text { TOTAL } & \end{aligned}$

Tons per cycle: $T$

- same as 2000 Shortwa11, Ideal Conditions Case

- 321.3 tons per cycle 
Shift production: TPMS

o Tons per machine-shift $=\frac{\mathrm{APT} \cdot \mathrm{A} \cdot \mathrm{T}}{\mathrm{C}}$

- APT = 357 min per machine-shift

$-A=0.60^{\circ}$

- $T=321.3$ tons per cycle

- $C=93.47$ min per cycle

TPMS $=\frac{357 \times 0.60 \times 321.3}{93.47}=736.31 \quad(740)$ 


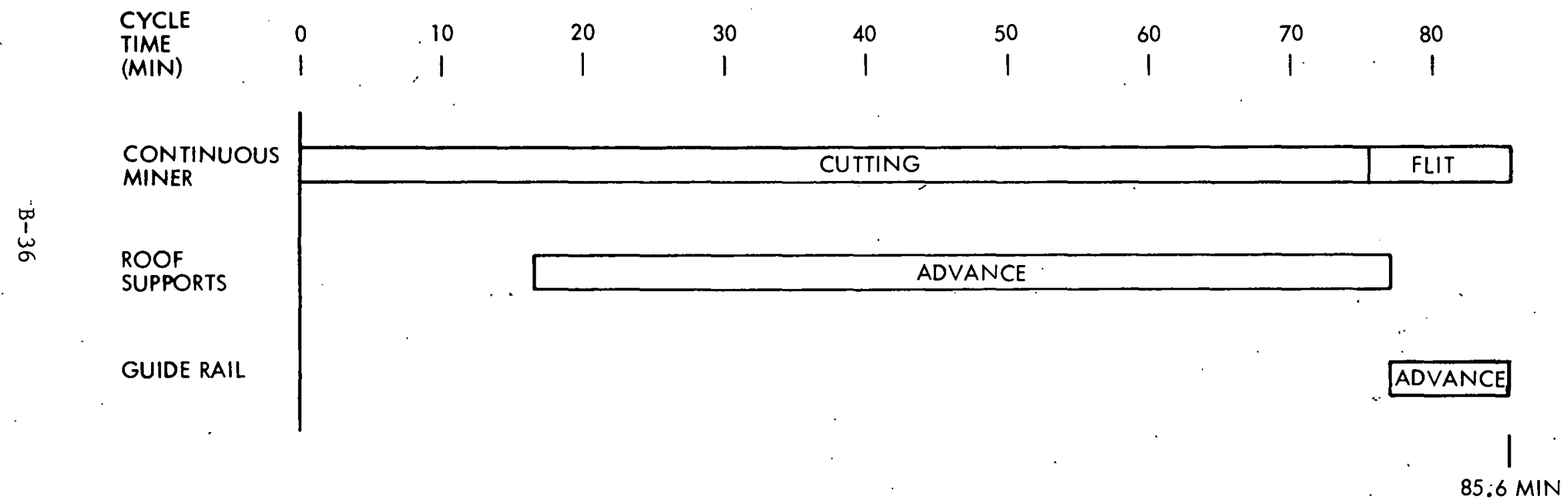

Figure B-11. Gantt Chart of Face Equipment Scheduling for 2000 Shortwall System in Average. Conditions 
G.

IDEAL CONDITIONS - DEVELOPMENT

Cycle time: C

- One sump cycle

- sump in $1 / 2$ diameter (18 in.) at $17 \mathrm{fpm}$

- shear down $36 \mathrm{in}$. at $34 \mathrm{fpm}$

- trim floor 18 in. at $17 \mathrm{fpm}$

- reposition drum $36 \mathrm{in}$. at $34 \mathrm{fpm}$

$$
\begin{aligned}
\mathrm{fpm} & =0.088 \\
& =0.088 \\
& =0.088 \\
& =\frac{0.088}{0.352} \approx
\end{aligned}
$$

- Shuttle car loading time

- capacity is 277 cubic ft

- one sump cycle produces 135 loose cubic ft of coal

- two cycles per shuttle car or $0.70 \mathrm{~min}$

- Shuttle car travel time

- the average shuttle car change-point distance from the change-point distance for $100 \mathrm{ft}$ of coal advance is $75.61 \mathrm{ft}$

- the average shuttle car travel distance from the change-point to the wait-point is $250.73 \mathrm{ft}$ for the standard shuttle çar and 187.32. ft for the off-standard shuttle car

- the tram rates of the shuttle cards in ideal conditions were assumed to be $7 \mathrm{ft}$ per s (420 fpm) empty, and $5 \mathrm{ft}$ per $\mathrm{s}(300 \mathrm{fpm})$ leaded

- change point travel times are as follows

$\begin{array}{lll}\text { empty } & = & 0.18 \mathrm{~min} \\ \text { loaded } & = & 0.25 \mathrm{~min}\end{array}$

- Shuttle car unloading time

- assumed to be $0.5 \mathrm{~min}$

- Maneuver time

- after a 20-ft advance, 10-ft wide cut is made, the continuous miner must maneuver to the other side of the 1 ift

- with a travel distance of $60 \mathrm{ft}$ at a rate of $60 \mathrm{fpm}$, maneuver time is $1.0 \mathrm{~min}$

- Shuttle car wait point time at dump

- $50 \mathrm{ft}$ of travel, full

- $50 \mathrm{ft}$ of travel, empty

$-0.15 \mathrm{~min}+0.17 \mathrm{~min}=0.29 \mathrm{~min}$

- Cut cycle time

- attached figure illustrates diagram and values used in the analysis which determined the cut cycle time

- cut cycle time - $23.56 \mathrm{~min}$

- Place change time

- average move is $325.37 \mathrm{ft}$

- tram rate for continuous miner is $60 \mathrm{fpm}$

- 5.42 min per place change

- Amortize section move-up time per $100 \mathrm{ft}$ of section advance

- 41 cuts per move

- I h to accomplish move

- 1.46 min per cut

- Total cut cycle time per $100 \mathrm{ft}$ of section advance $23.56 \mathrm{~min}+5.42 \mathrm{~min}+1.46 \mathrm{~min}=30.44 \mathrm{~min}$ 
Tons per cycle: T

- One cut is $20 \mathrm{ft} \times 20 \mathrm{ft} \times 6 \mathrm{ft}$

- 102 tons per cycle

Shift production: TPMS

- Tons per machine-shift $=\frac{\mathrm{APT} \cdot \mathrm{A} \cdot \mathrm{T}}{\mathrm{C}}$

- APT $=357$ min per machine-shift.

$-A=0.63$

- $T=102$ tons per cycle.

- $C=30.44$ min per cycle

TMPS $=\frac{357 \times 0.63 \times 103}{30.44}=753.64$ (750) 


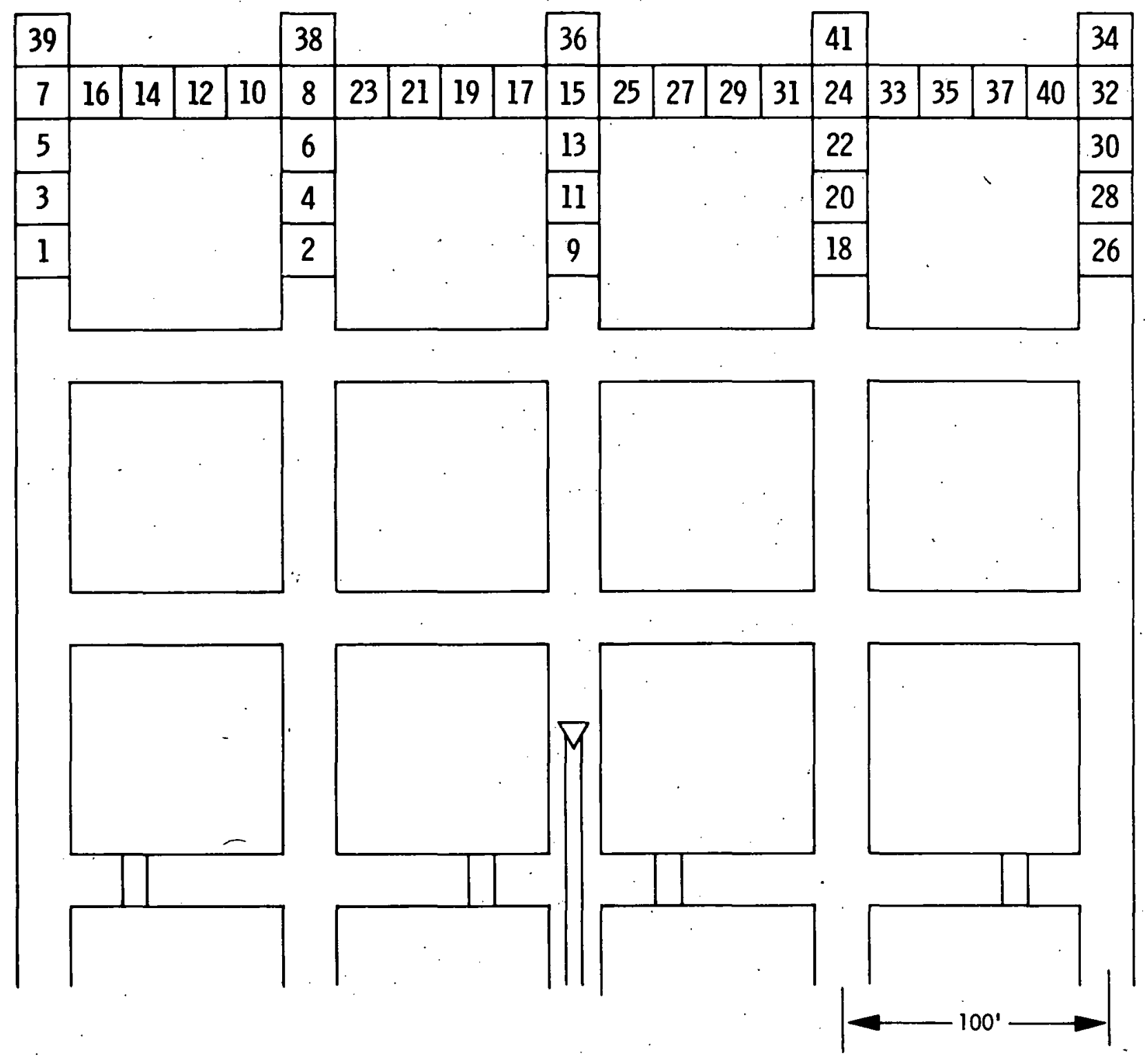

Figure B-12. Lift Sequence for 1980 Room-and-Pillar Cases, Development 


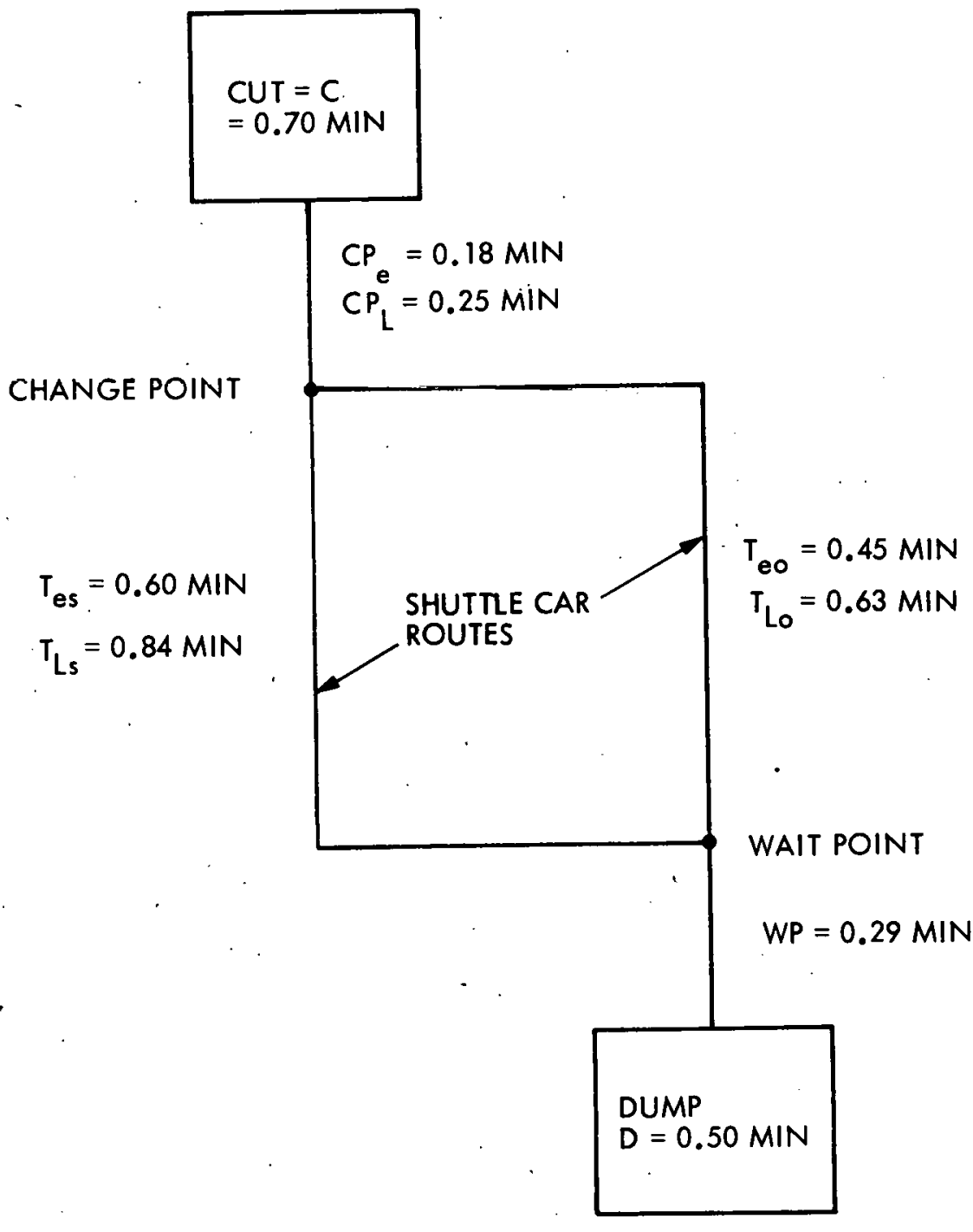

$C=$ CUT TIME

$C P_{e}=$ CHANGE POINT TRAVEL TIME, EMPTY

$C P_{1}=$ CHANGE POINT TRAVEL TIME, LOADED

$T_{\text {es }}=$ TRAVEL TIME, STANDARD CAR, EMPTY

$T_{L s}=$ TRAVEL TIME, STANDARD CAR, LOADED

$T_{\text {eo }}=$ TRAVEL TIME, OFF-STANDARD CAR, EMPTY

$T_{\text {Lo }}=$ TRAVEL TIME, OFF - STANDARD CAR, LOADED

WP = WAIT POINT TRAVEL TIME

$D=$ DUMP TIME

Figure B-13. Elemental Times Used in 1980 Room-and-Pillar Ideal Conditions Case to Determine Cycle Time for Development 


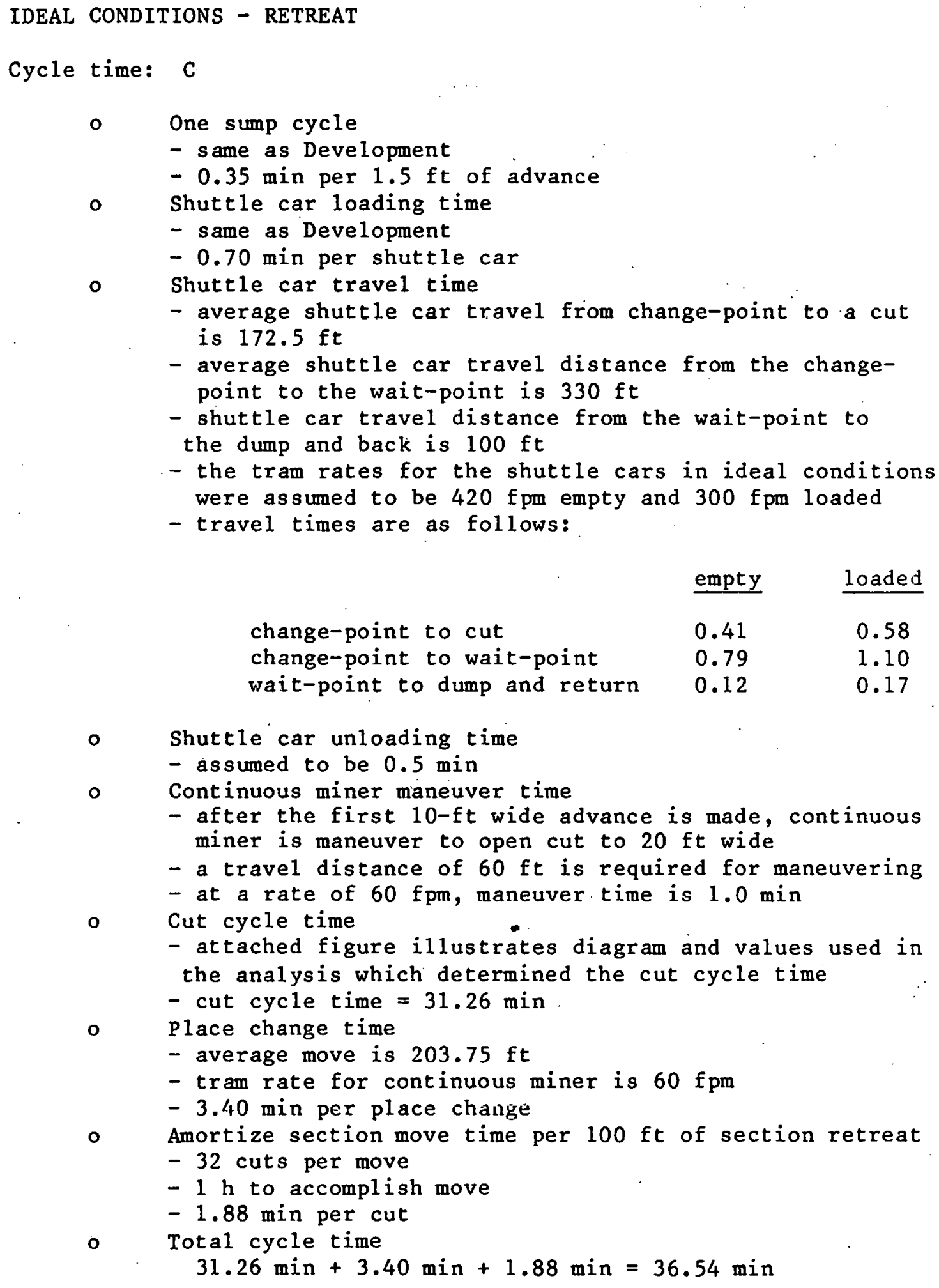

$\begin{array}{lll} & \text { empty } & \text { loaded } \\ \text { change-point to cut } & 0.41 & 0.58 \\ \text { change-point to wait-point } & 0.79 & 1.10 \\ \text { wait-point to dump and return } & 0.12 & 0.17\end{array}$

- Shuttle car unloading time

- assumed to be $0.5 \mathrm{~min}$

- Continuous miner maneuver time

- after the first 10-ft wide advance is made, continuous miner is maneuver to open cut to $20 \mathrm{ft}$ wide

- a travel distance of $60 \mathrm{ft}$ is required for maneuvering

- at a rate of $60 \mathrm{fpm}$, maneuver time is $1.0 \mathrm{~min}$

o

Cut cycle time

- attached figure illustrates diagram and values used in the analysis which determined the cut cycle time

- cut cycle time $=31.26 \mathrm{~min}$

- Place change time

- average move is $203.75 \mathrm{ft}$

- tram rate for continuous miner is $60 \mathrm{fpm}$

- 3.40 min per place change

- Amortize section move time per $100 \mathrm{ft}$ of section retreat

- 32 cuts per move

- $1 \mathrm{~h}$ to accomplish move

- 1.88 min per cut

o

Total cycle time

$31.26 \mathrm{~min}+3.40 \mathrm{~min}+1.88 \mathrm{~min}=36.54 \mathrm{~min}$

Tons per cycle: T

- Average cut is 20-ft long, 30-ft wide, and 6-ft high

- 102 tons per cycle 
Shift production: TPMS

- Tons per machine-shift $=\frac{\mathrm{APT} \cdot \mathrm{A} \cdot \mathrm{T}}{\mathrm{C}}$

- APT $=357$ min per machine-shift

$-\mathrm{A}=0.63$

- $\mathrm{T}=102$ tons per cycle

- C $=36.54 \mathrm{~min}$ per cycle

TPMS $=\frac{357 \times 0.63 \times 102}{36.54}=627.83(630)$ 


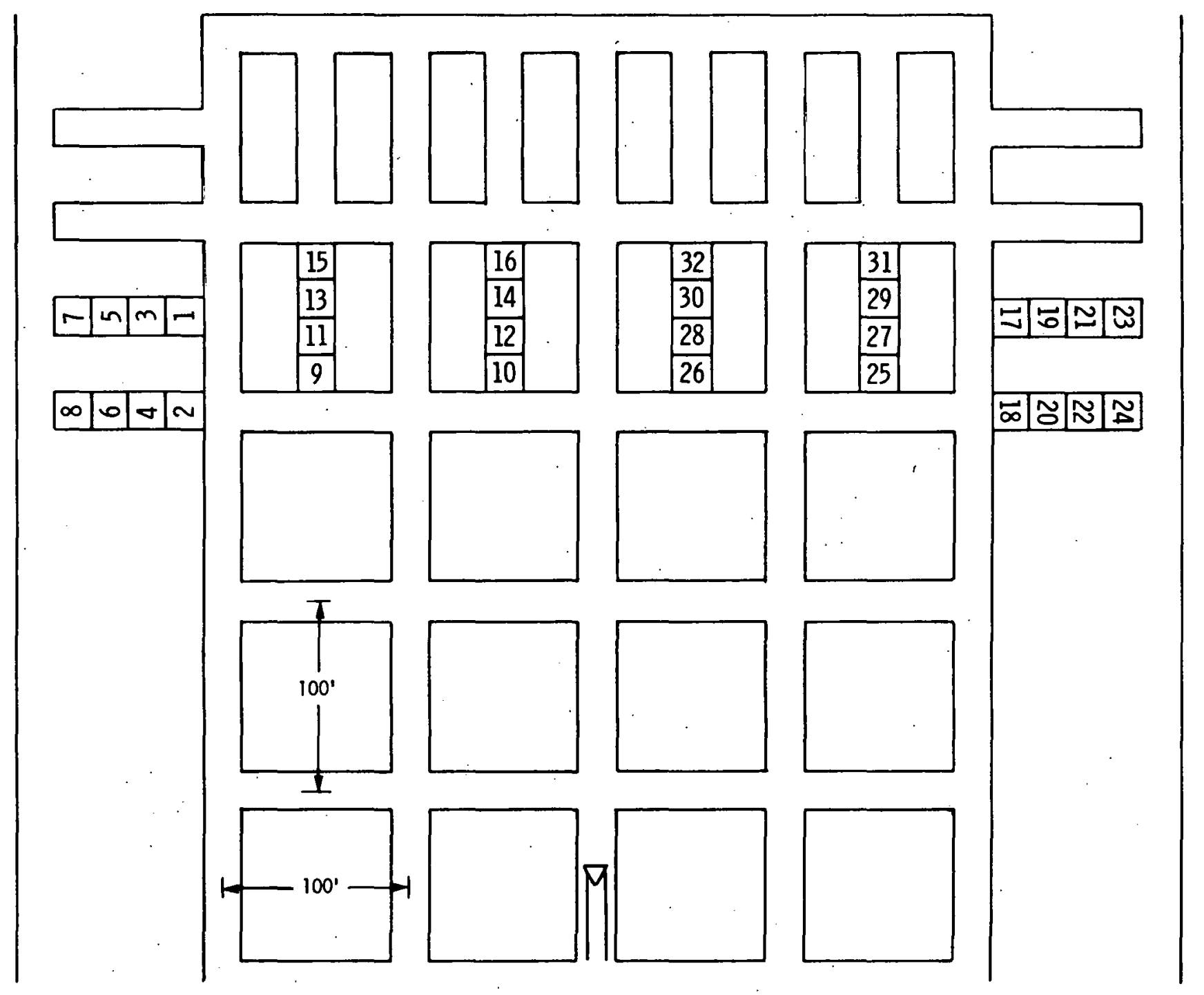

Figure E-14. Lift Sequence for 1980 Room-and-Pillar Cases, Retreat 


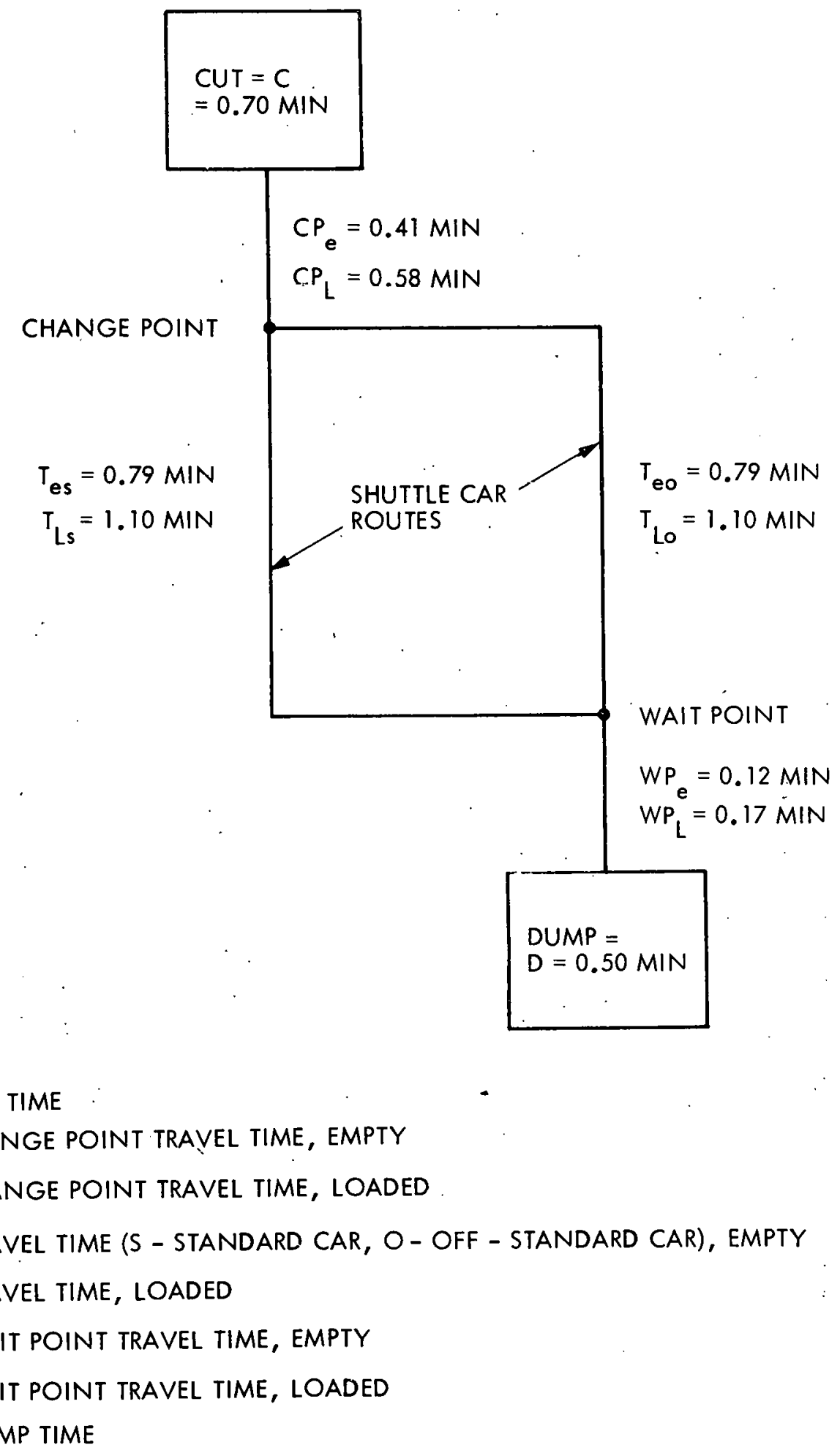

Figure B-15. Elemental Times Used in 1980 Room-and-Pillar Ideal Conditions Case to Determine Cycle Time for Retreat 


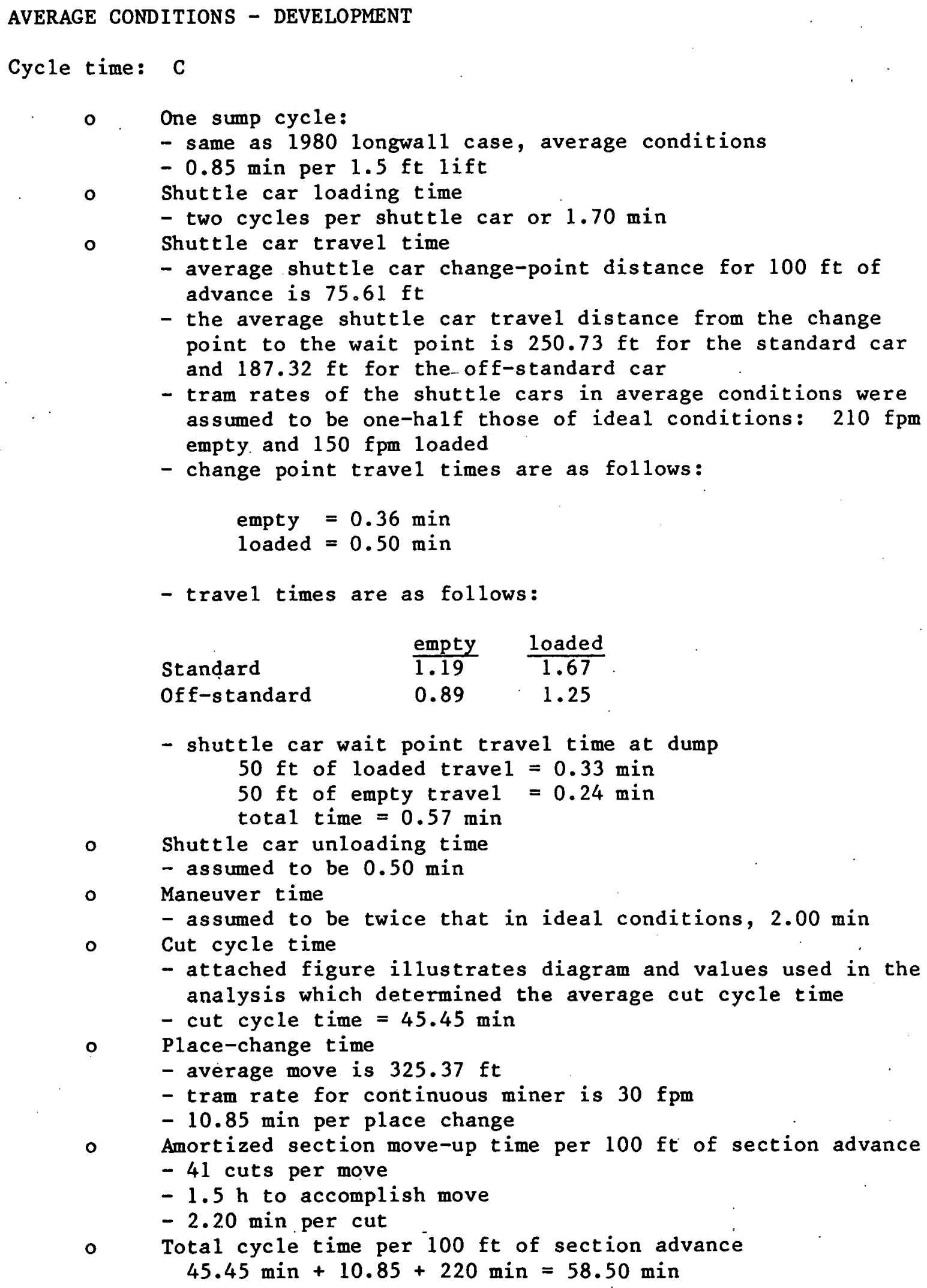


Tons per cycle: $\mathrm{T}$

$$
\begin{aligned}
& \text { - Same as ideal case } \\
& \text { - } 102 \text { tons per cycle }
\end{aligned}
$$

Shift production: TPMS

- Tons per machine shift $=\frac{\text { APT } \cdot A \cdot T}{C}$.

- APT $=357$ min per machine-shift

- $\mathrm{A}=0.50$

- $T=102$ tons per cycle

- $\mathrm{C}=58.50$ min per cycle

TPMS $=\frac{357 \times 0.50 \times 102}{58.50}=311.23(310)$ 


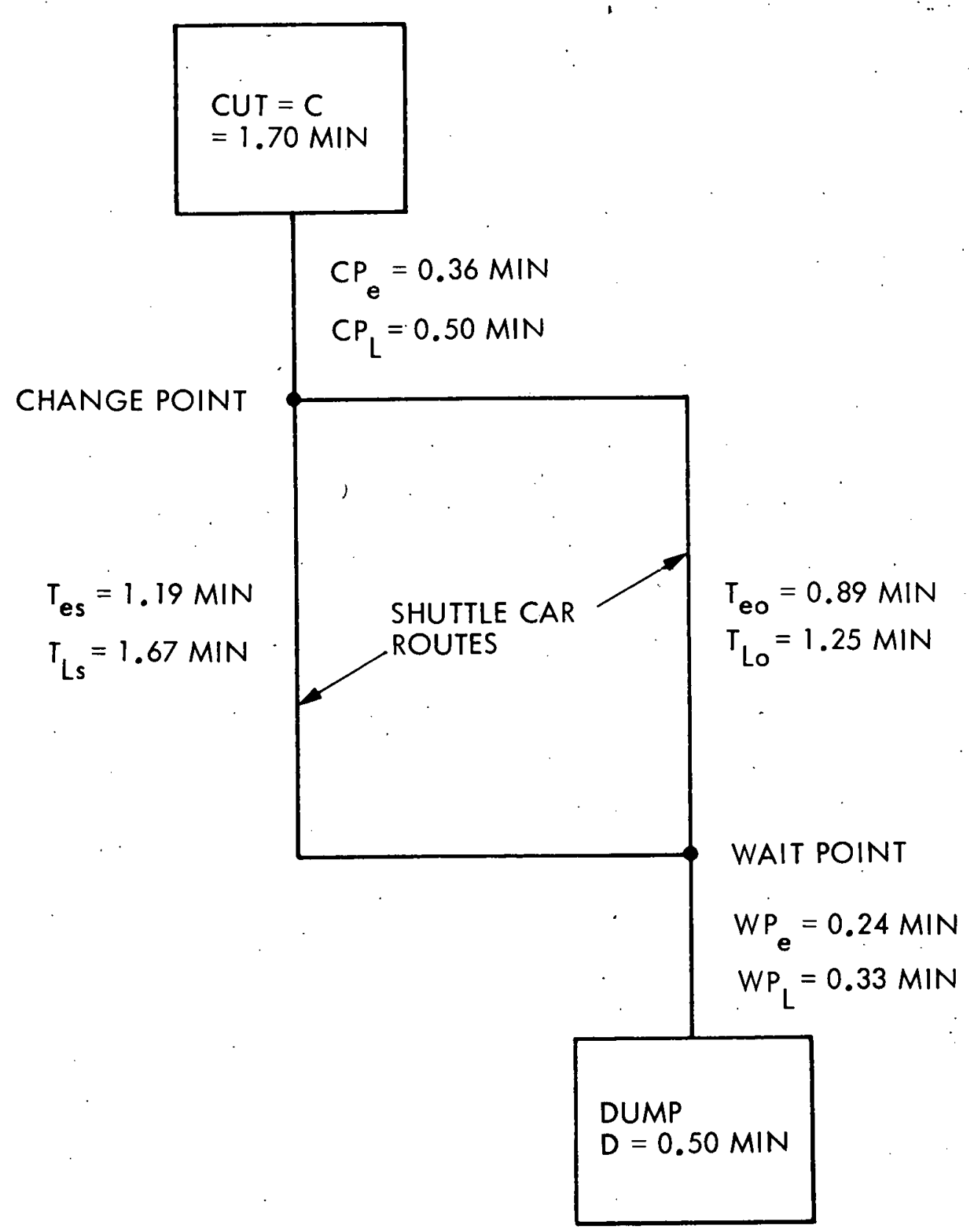

Figure B-16. Elemental Times Used in 1980 Room-and-Pillar Average Conditions Case to Determine Cycle Time for Development 


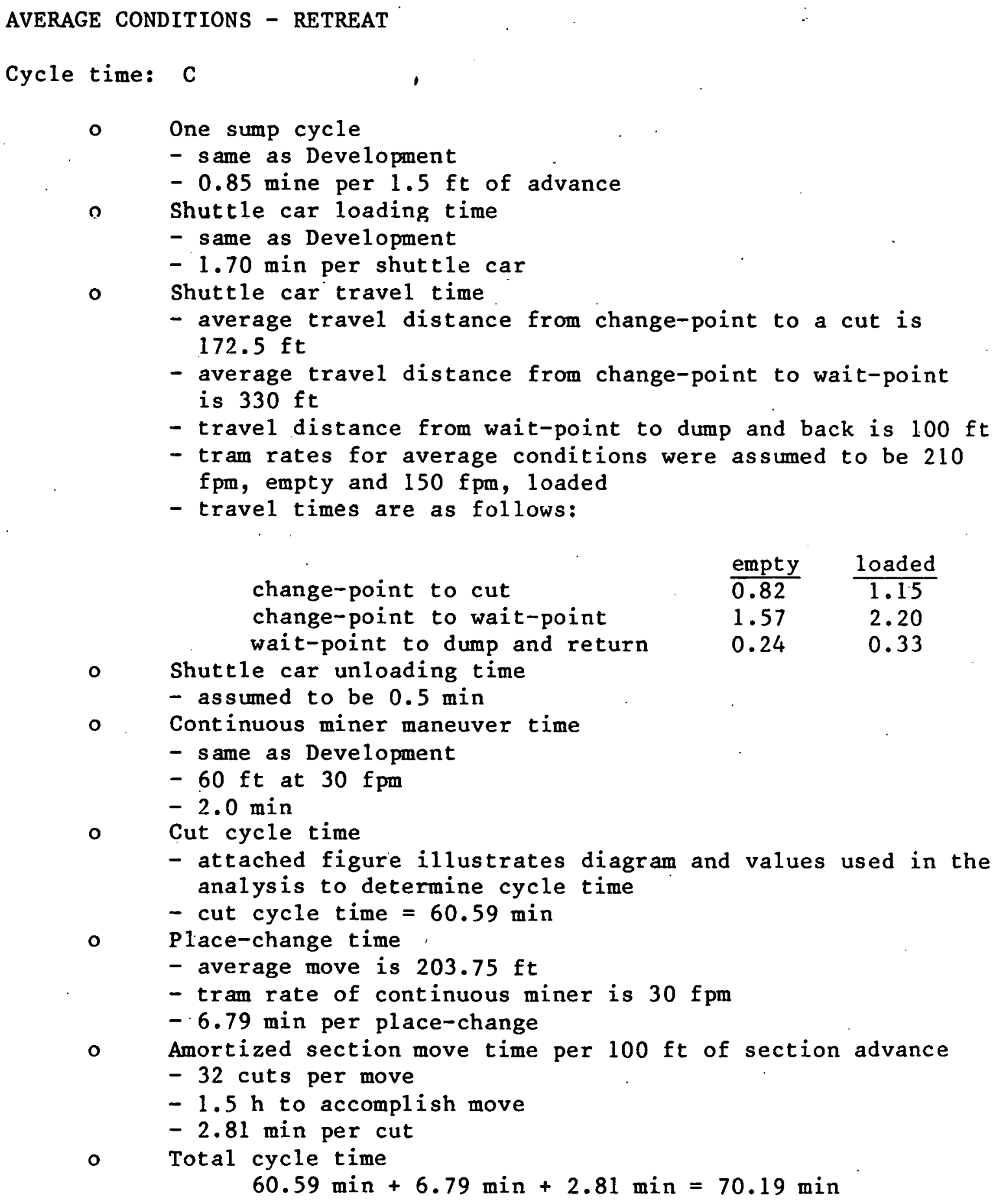


Shift production: TPMS

- Tons per machine-shift $=\frac{\mathrm{APT} \cdot \mathrm{A} \cdot \mathrm{T}}{\mathrm{C}}$

- APT $=357$ min per machine-shift

$-A=0.50$

- $T=102$ tons per cycle

- $C=70.19 \mathrm{~min}$ per cycle

TPMS $=\frac{357 \times 0.50 \times 102}{70.19}=259.39 \quad(260)$ 


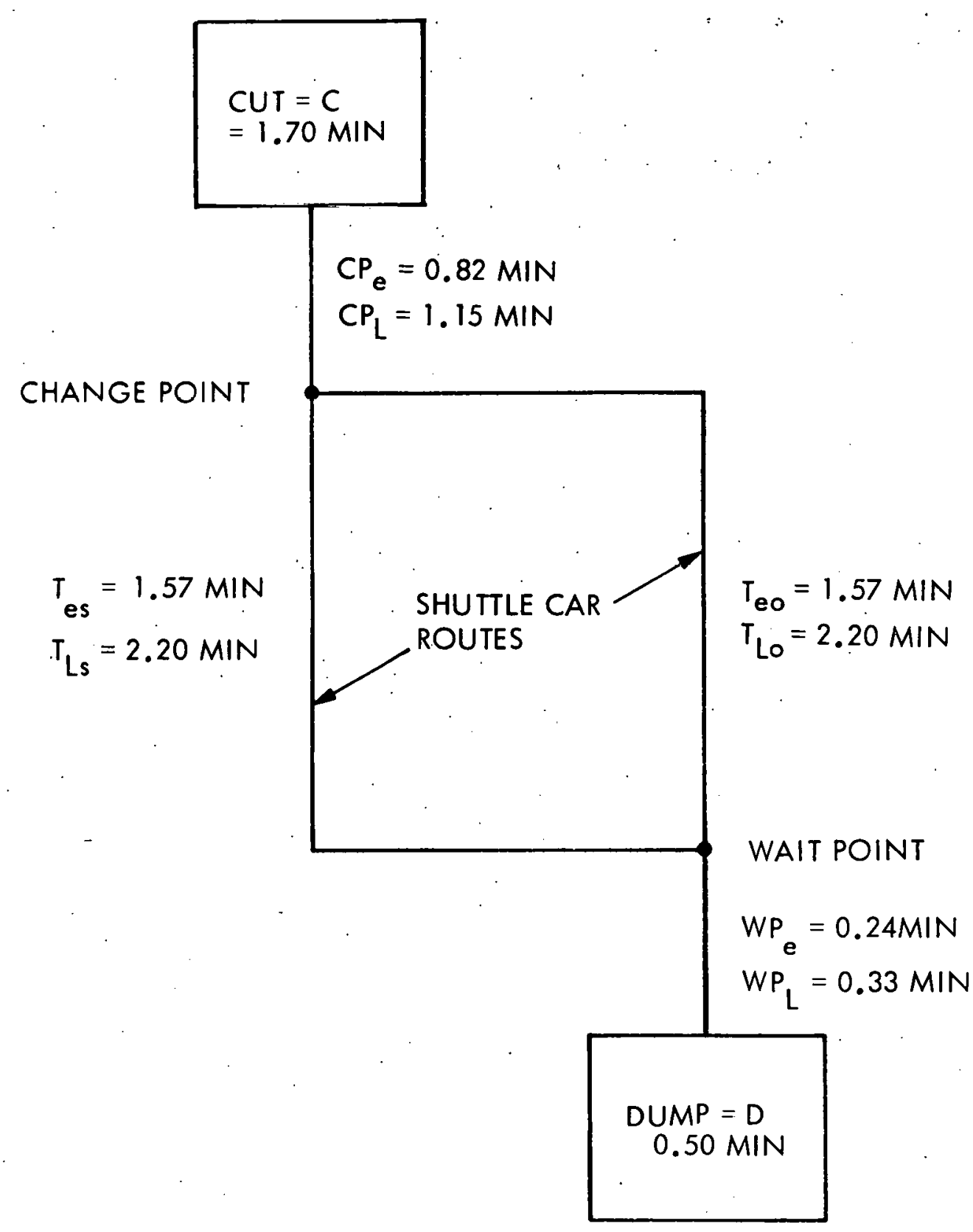

Figure B-17. Elemental Times Used in 1980 Room-and-Pillar Average Conditions Case to Determine Cycle Time for Retreat 
H. 2000 ROOM-AND-PILLAR

IDEAL CONDITIONS - DEVELOPMENT

Cycle time: $\mathrm{C}$

- One sump cycle

- same as 1980 Room-and-Pillar case

- $0.35 \mathrm{~min}$ per $1.5 \mathrm{ft}$ of advance

- One lift

- same as 2000 Longwa11 Development case but with different place-change time

- 2000 R\&P place-change average distance is $228.46 \mathrm{ft}$ at $60 \mathrm{fpm}$, therefore $3.81 \mathrm{~min}$ per move

- cycle time for lift +45.32 min ( 2000 Longwall case)

- 3.97 min (2000 Longwall place-change time) $+3.81 \mathrm{~min}$ (2000 R\&P place-change time) $45.16 \mathrm{~min}$

- Amortized section move-up time per $80-\mathrm{ft}$ lift

- $1.0 \mathrm{~h}$ to accomplish move

- 9 lifts per move

- $6.67 \mathrm{~min}$ per lift

- Total cycle time per $80-\mathrm{ft}$ lift

$$
45.16 \mathrm{~min}+6.67 \mathrm{~min}=51.83 \mathrm{~min}
$$

Tons per cycle: T
- 9 lifts per move
- $\quad 3455.8$ tons per move
- $\quad 383.98$ tons per cycle

Șhift production: TPMS

- Tons per machine-shift $=\frac{\mathrm{APT} \cdot \mathrm{A} \cdot \mathrm{T}}{\mathrm{C}}$

- APT $=357$ min per machine-shift

$-\mathrm{A}=0.63$

$-\mathrm{T}=383.98$ tons per cycle

- $\mathrm{C}=51.81 \mathrm{~min}$ per cycle

$\mathrm{TPMS}=\frac{357 \times 0.63 \times 383.98}{51.83}=1666.23$ 


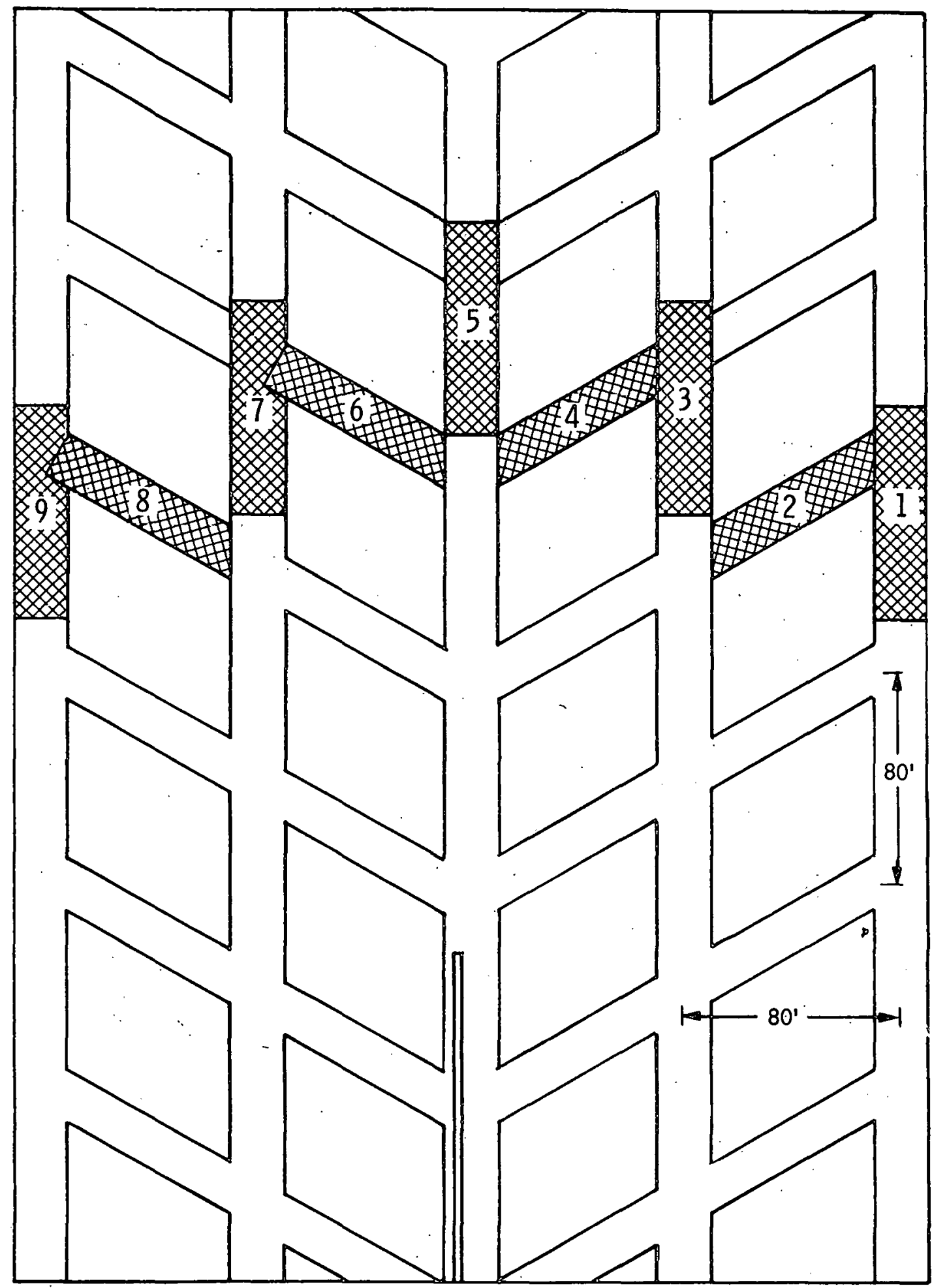

Figure B-18. Lift Sequence for 2000 Room-and-Pillar Cases, Development 
IDEAL CONDITIONS - RETREAT

Cycle time: C

- One sump cycle

- same as 2000 R\&P Ideal Conditions case, Development

- $0.35 \mathrm{~min}$ per $1.5 \mathrm{ft}$ of advance

- One lift length

- average lift length is $74.25 \mathrm{ft}$

- average place-change distance is $194.76 \mathrm{ft}$

- cycle

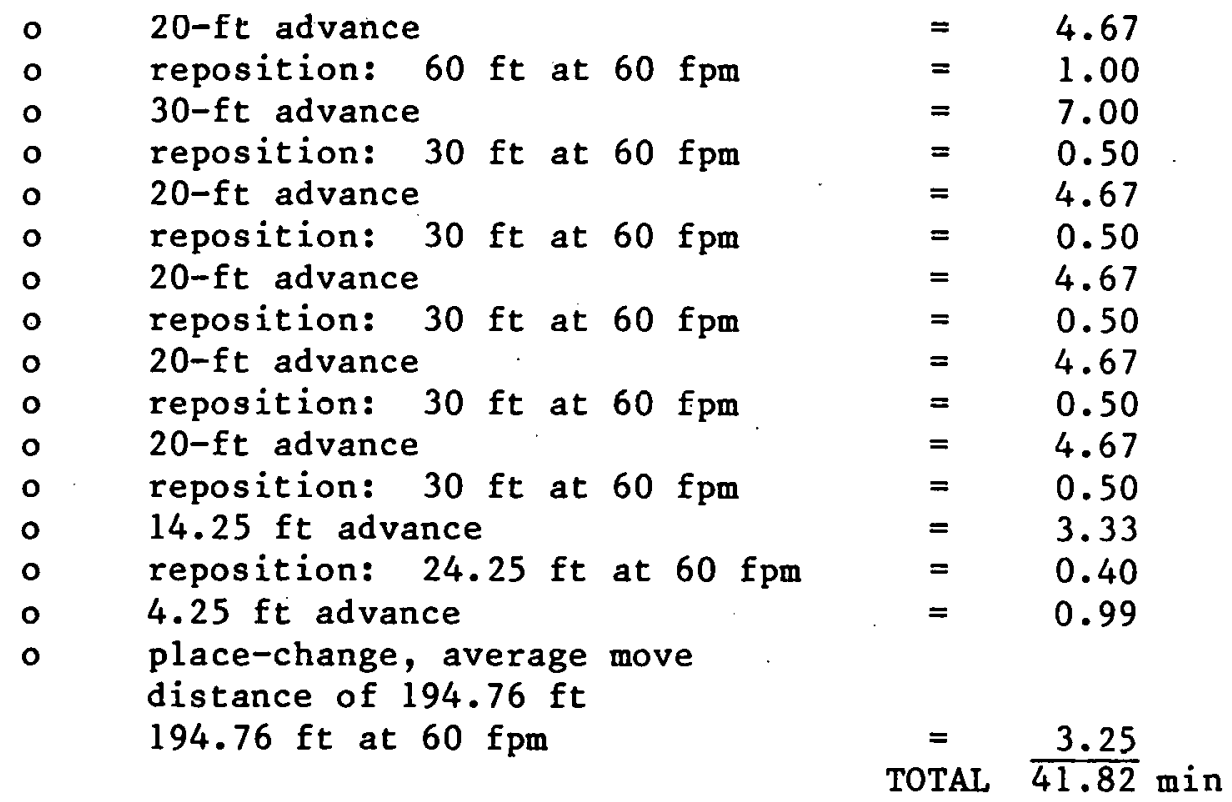

- Amortized section move-up time per shift

- $1.0 \mathrm{~h}$ to accomplish move

- 8 lifts per move

$-7.50 \mathrm{~min}$

- Total cycle time per lift

$41.82 \mathrm{~min}+7.50 \mathrm{~min}=49.32 \mathrm{~min}$

Tons per cycle time: T

- 8 lifts per move

- 2616.3 tons per move

- $\quad 327.04$ tons per 1ift 
Shift producton: TPMS

- Tons per machine-shift $=\frac{\mathrm{APT} \cdot \mathrm{A} \cdot \mathrm{T}}{\mathrm{C}}$

- $\mathrm{APT}=35 \mathrm{~min}$ per machine-shift

$-\mathrm{A}=0.63$

- $T=327.04$ tons per cycle

- C $=49.43 \mathrm{~min}$ per cycle

TPMS $=\frac{357 \times 0.63 \times 327.04}{49.32}=1491.37$ 


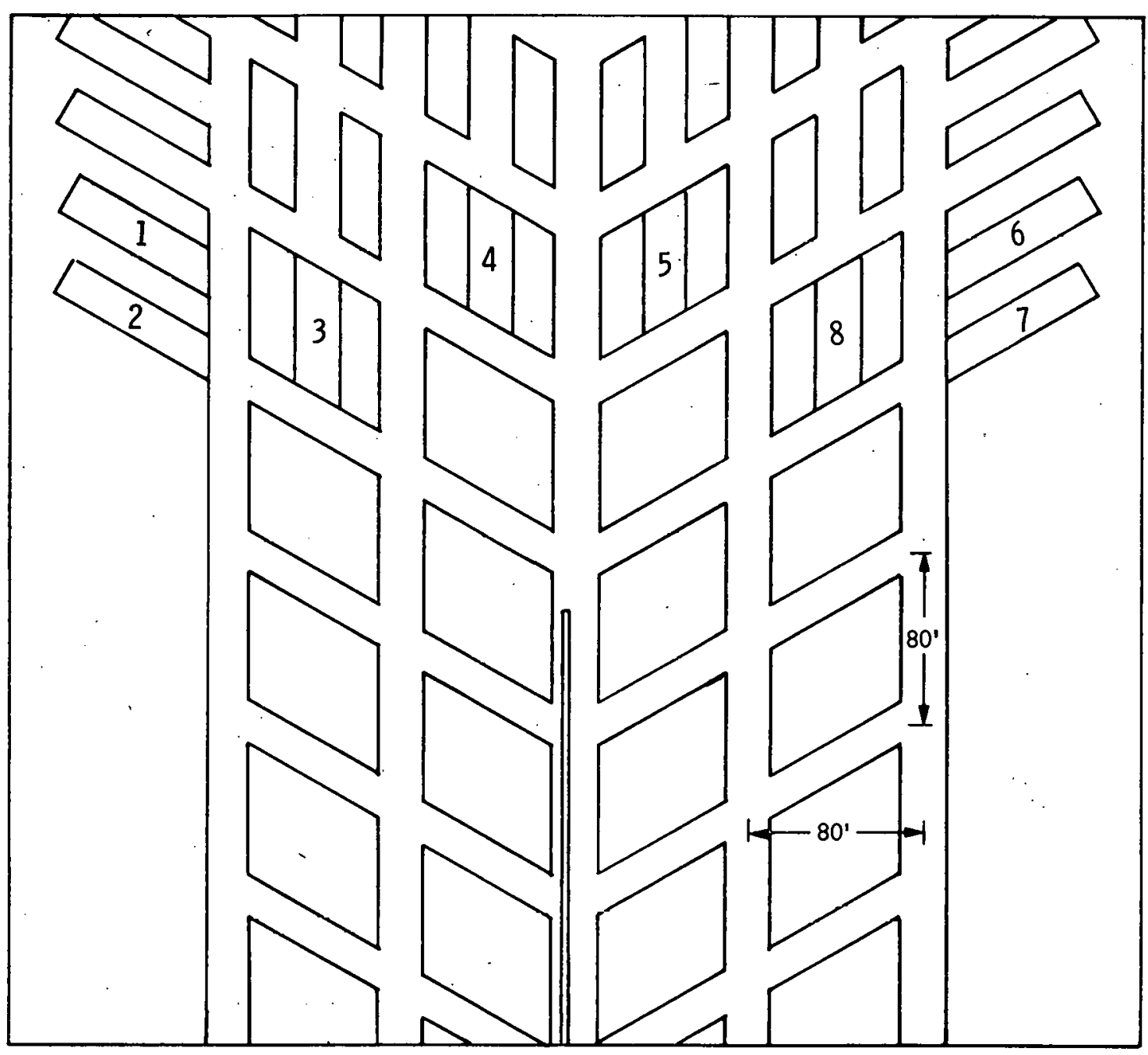

Figure B-19. Lift Sequence for 2000 Room-and-Pillar Cases, Retreat 
AVERAGE CONDITIONS - DEVELOPMENT

Cycle time: C

- One sump cycle

- same as 1980 R\&P, Average Conditions case

$-0.85 \mathrm{~min}$ per $1.5 \mathrm{ft}$ of advance

- One lift

- same as 2000 Longwal1 Development case, but with different place-change time

- $+106.59 \mathrm{~min}$ ( 2000 Longwall case)

- $7.94 \mathrm{~min}$ (2000 Longwal1 place-change time)

- $7.62 \mathrm{~min}$ (2000 R\&P place-change time) $106.27 \mathrm{~min}$

- Amortized section move time per 80-ft lift

- $1.5 \mathrm{hr}$ per move

- 9 1ifts per move

- 10 min per lift

- Cycle time per 80-ft lift

$$
106.27 \mathrm{~min}+10.00 \mathrm{~min}=116.27 \mathrm{~min}
$$

Tons per cycle: T

- $\quad 9$ lifts per move
$\circ \quad 3455.8$ tons per move
$\circ \quad 383.98$ tons per cycle

Shift Production: TPMS

- Tons per machine-shift $=\frac{\mathrm{APT} \cdot \mathrm{A} \cdot \mathrm{T}}{\mathrm{C}}$

- APT $=357$ min per machine-shift

$-A=0.50$

$-T=383.98$ tons per cycle

$-C=116.27$ min per cycle

$$
\text { TPMS }=\frac{357 \times 0.50 \times 383.98}{116.27}=589.49(590)
$$


AVERAGE CONDITIONS - RETREAT

Cycle time: C

- One sump cycle

- same as 2000 R\&P Development

$-0.85 \mathrm{~min}$ per $1.5 \mathrm{ft}$ of advance

- One lift length

- average lift length is $74.25 \mathrm{ft}$

- average place-change distance is $194.76 \mathrm{ft}$

- cycle

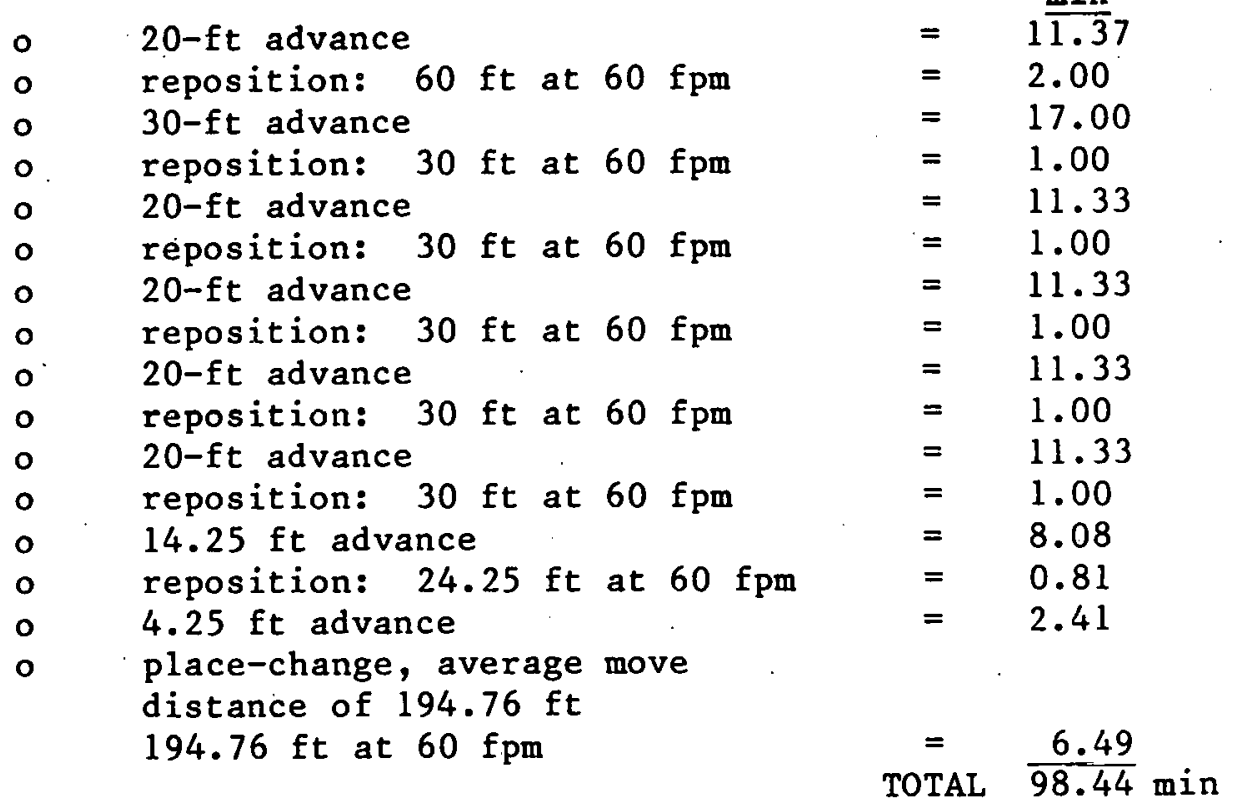

- Amortized section move-up time per shift

- $1.5 \mathrm{~h}$ to accomplish move

- 8 lifts per move

- 11.25 min per lift

0

Cycle time per lift

$$
98.44 \mathrm{~min}+11.25 \mathrm{~min}=109.69 \mathrm{~min}
$$

Tons per cycle time: T

- 81 ifts per move
o. $\quad 2616.3$ tons per move
o $\quad 327.04$ tons per lift

Shift producton: TPMS

- Tons per machine-shift $=\frac{\mathrm{APT} \cdot \mathrm{A} \cdot \mathrm{T}}{\mathrm{C}}$ 


$$
\begin{aligned}
& - \text { APT }=357 \text { min per machine-shift } \\
& -A=0.50 \\
& -T=327.04 \text { tons per cycle } \\
& -C=109.69 \text { min per cycle } \\
& \text { TPMS }=\frac{357 \times 0.50 \times 327.04}{109.69}=532.20
\end{aligned}
$$


APPENDIX C

COST ANALYSIS INPUTS

The purpose of Appendix C, Cost Analysis Inputs is to identify the inputs that were required for the NUS coal costing model in order to simulate the case studies of this moving baseline effort. The items included in Appendix $C$ are the calculations that modified the system productivities of the Production Analys is task for input to the NUS model, design capacity calculations, and the requirements and costs for section equipment, electric power, salaried personnel, and hourly laborers. 
MODIFIED SHIFT PRODUCTION

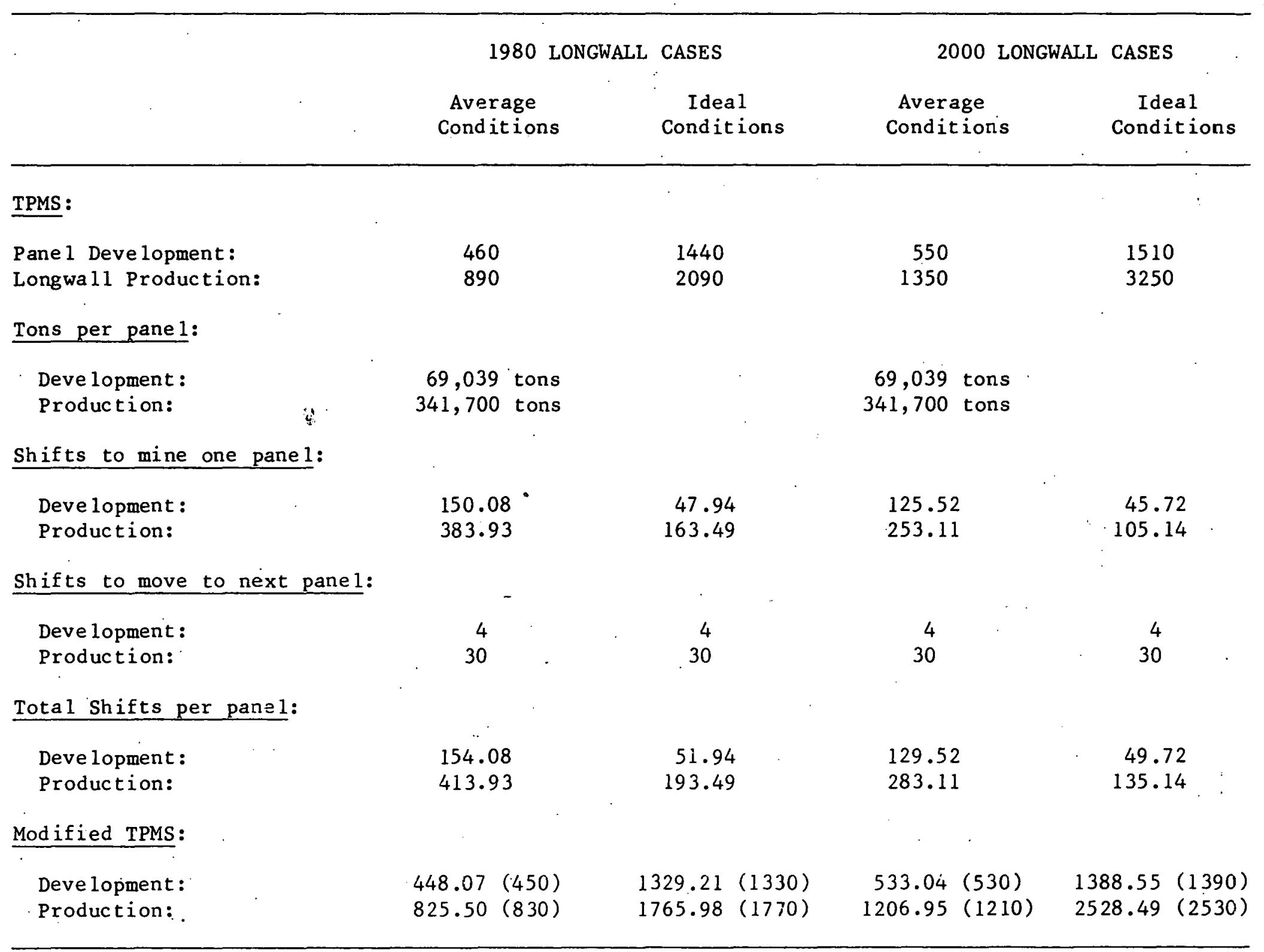


Design Capacity $=$

$[(N(d) \times \operatorname{TPMS}(d))+(N(P) \times \operatorname{TPMS}(P))] S \times D \times(1-R)$

$N(d)=$ Number of development units per shift

TPMS $(\mathrm{d})=$ Productivity of development units

$N(P)=$ Number of productions per shift

TPMS $(P)=$ Productivity of production units

$S=$ Shifts per day

$D=$ Days per week

$\mathrm{R}=$ Reject precentage

\begin{tabular}{ccccc}
\hline & \multicolumn{2}{c}{1980 LONGWALL } & \multicolumn{2}{c}{2000 LONGWALL } \\
& $\begin{array}{c}\text { Average } \\
\text { Conditions }\end{array}$ & $\begin{array}{c}\text { Ideal } \\
\text { Conditions }\end{array}$ & $\begin{array}{c}\text { Average } \\
\text { Conditions }\end{array}$ & $\begin{array}{c}\text { Idea } \\
\text { Conditions }\end{array}$ \\
\hline N (d) & 3 & 2 & 3 & 2 \\
TPMS (d) & 450 & 1330 & 530 & 1390 \\
N (P) & 1 & 1 & 1 & 2530 \\
TPMS (P) & 830 & 1770 & 1210 & 3 \\
S & 3 & 3 & 3 & 220 \\
D & 220 & 220 & 220 & $2,768,634$ \\
R & $21 \%$ & $21 \%$ & $21 \%$ & \\
$\begin{array}{l}\text { Design } \\
\text { Capacity in } \\
\text { clean tons }\end{array}$ & $1,136,652$ & $2,309,802$ & $1,459,920$ & \\
\hline
\end{tabular}


1980 LONGWALL CASES

Average

Idea 1

Conditions

Conditions

\begin{tabular}{|c|c|c|}
\hline Continuous Miner Units & Cost/unit (1) & Tota 1 Cost \\
\hline $\begin{array}{l}\text { Continuous Miner } \\
\text { Mobile Bridge Carrier System }(2) \\
\text { Roof Bolter } \\
\text { Auxiliary Fan } \\
\text { Scoop with Batteries \& Charger } \\
\text { Bantam Duster } \\
\text { Trickle Duster } \\
\text { Section Power Center \& Cables } \\
\text { Parts Car } \\
\text { Oil Storage Car } \\
\text { Section Tools } \\
\text { Ventilation Tubes } \\
\text { Section Welder } \\
\text { Section Haulage Belt (42 in., } 3000 \mathrm{ft}) \\
\text { Fire Suppression }\end{array}$ & $\begin{array}{r}\$ 412,000 \\
242,000 \\
76,700 \\
18,000 \\
77,200 \\
18,000 \\
15,000 \\
53,000 \\
10,500 \\
12,000 \\
7,700 \\
2,000 \\
1,700 \\
\$ 42.5 / \mathrm{ft} \\
4,200\end{array}$ & $\begin{array}{r}\$ 1,236,000 \\
726,000 \\
230,100 \\
90,000 \\
231,000 \\
54,000 \\
75,000 \\
159,000 \\
31,500 \\
36,000 \\
23,100 \\
6,000 \\
5,100 \\
255,000 \\
12,600\end{array}$ \\
\hline 1980 Do 11 ars & TOTAL & 171,000 \\
\hline \multicolumn{3}{|c|}{$\begin{array}{l}\text { 1. All costs were found or were updated from information in } \\
\text { IOM FF-345-79-239 (P. G. Gordon), JPL, 12/17/79 } \\
\text { The } 1977 \text { cost extracted from Conceptual Design of a Fully } \\
\text { Automated Continuous Mining System Operating Under Remote } \\
\text { Supervisory Control, USBM Contract } 50166007 \text {, Final Report } \\
\text { Arthur D. Little, Inc., 1977. }\end{array}$} \\
\hline
\end{tabular}


2000 LONGWALL CASES

Average

Conditions
Ideal

Conditions

\section{Continuous Miner Units}

Continuous Miner

Mobile Bridge Carrier System(2)

Roof Bolter

Auxiliary Fan

Scoop with Batteries \& Charger

Bantam Duster

Trickle Duster

Section Power Center \& Cables

Parts Car

Oil Storage Car

Section Tools

Ventilation Tubes

Section Welder

Section Haulage Belt (42 in., $3000 \mathrm{ft}$ )

Fire Suppression

\begin{tabular}{c} 
Cost/unit \\
\hline$\$ 412,000$ \\
242,000 \\
76,700 \\
18,000 \\
77,200 \\
18,000 \\
15,000 \\
53,000 \\
10,500 \\
12,000 \\
7,700 \\
2,000 \\
1,700 \\
$\$ 42.5 / \mathrm{ft}$ \\
4,200
\end{tabular}

\section{No.}

TOTAI

\section{Total Cost}

$\$ 1,236,000$

726,000

230,100

90,000

231,000

54,000

75,000

159,000

31,500

36,000

23,100

6,000

5,100

255,000

12,600

\section{No. Total Cost}

$2 \$ 824,000$

2

4

3

2

2

3

3

2

2

2

2

2

1

484,000

306,800

54,000

154,400

36,000

45,000

106,000

21,000

24,000

15,400

4,000

3,400

127,500

8,400

1980 Dollars

$\$ 3,171,000$

$\$ 2,213,900$

1. All costs were found or were updated from information in IOM FF-345-79-239 (P. G. Gordon), JPL, 12/17/79

2. The 1977 cost extracted from Conceptual Design of a Fully Automated Continuous Mining System Operating Under Remote Supervisory Control, USBM Contract 50166007, Final Report, Arthur D. Little, Inc., 1977. 
AVERAGE \& IDEAL CONDITIONS EQUIPMENT COST

1980 DOLLARS

Longwa11 Unit No. Cost/Unit (1) Total Cost

Longwa11 Face Equipment:

$1 \$ 5,170,000$

$\$ 5,170,000$

- Shearer

- Face Conveyor

- Self-Advancing Supports (500-ft face)

- Stageloader

- Electrical Equipment

- Controls

Section Haulage Belt (42 in. - $3000 \mathrm{ft}$ ) 1

Fire Suppression

Parts Car

Oil Storage Car

Section Tools

Section Welder

Scoop w/Batteries \& Charges

1 .

$\$ 42.5 / \mathrm{ft}$

127,500

1

4,200

4,200

$1 \quad 10,500$

10,500

1

12,000

12,000

1

7,700

7,700

1

1,700

$-1,700$

1

77,200

TOTAL

$\$ 5,410,800$

1. A11 costs were found or updated from information in IOM FF-345-79-239 (P. G. Gordon), JPL, 12/17/79 


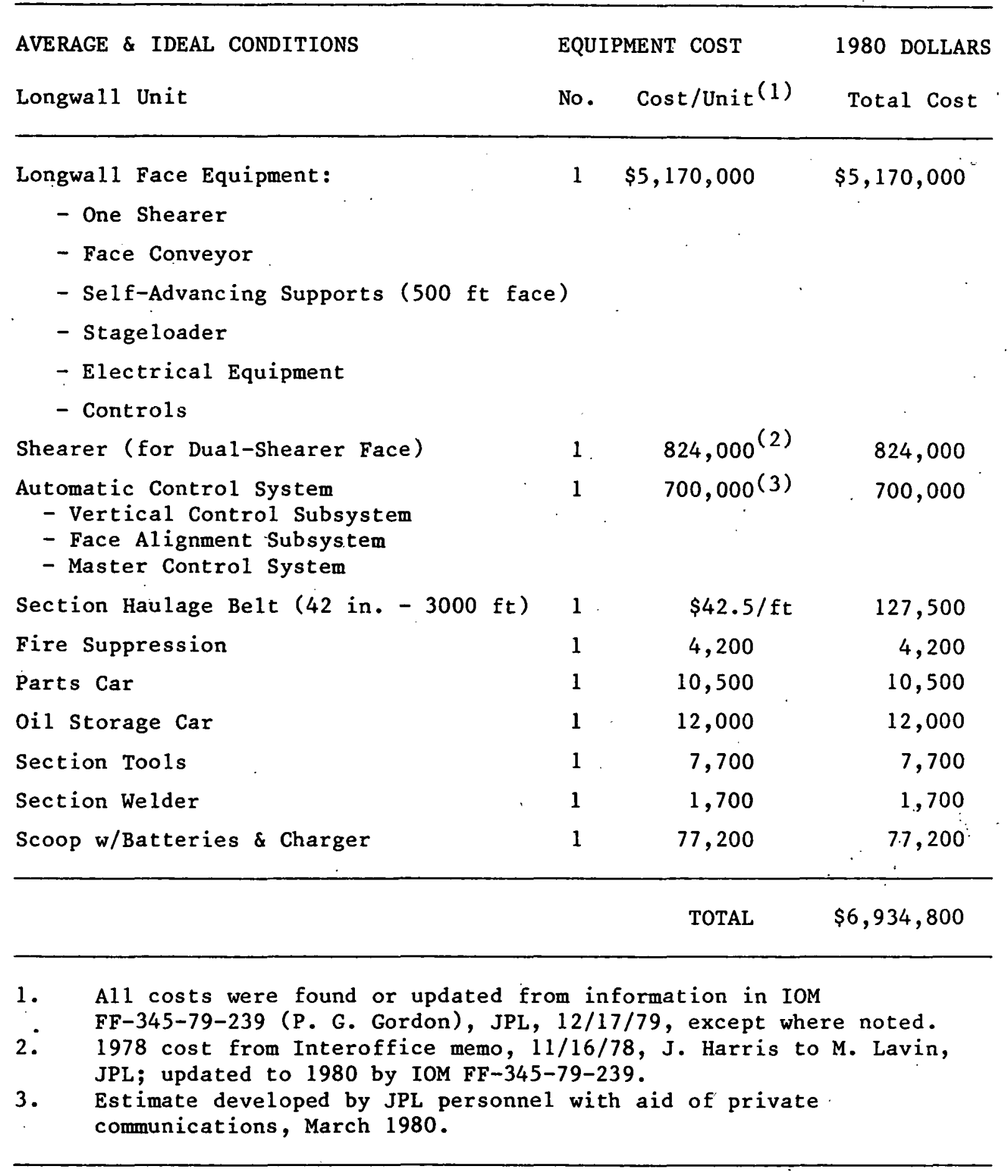


1980 LONGWALL CASES

\begin{tabular}{|c|c|c|c|c|c|c|c|}
\hline \multirow{2}{*}{$\begin{array}{l}\text { AVERAGE CONDITIONS } \\
\text { Component }\end{array}$} & \multirow[b]{2}{*}{ No. } & \multicolumn{3}{|c|}{ POWER COST } & \multirow[b]{2}{*}{$\mathrm{kW}$} & \multicolumn{2}{|c|}{1980 DOLLARS } \\
\hline & & hp/Unit & Total hp & h/day & & Total kW-h & Req. \\
\hline Longwall Unit & 1 & 625 & 625 & 10 & 466 & 4,660 & \\
\hline Continuous Miner & 3 & 600 & 1800 & 9 & 1342 & 12,078 & \\
\hline MBC Unit & 3 & 120 & 360 & 9 & 268 & 2,412 & \\
\hline Roof Bolter & 3 & 50 & 150 & 12 & 112 & 1,344 & \\
\hline Auxiliary Fan & 5 & 15 & 75 & $\therefore \quad 18$ & 56 & 1,008 & \\
\hline Mantrip Jeep & 6 & 15 & 90 & 4 & 67 & 268 & \\
\hline Mechanic Jeep & 3 & 15 & 45 & 15 & 34 & 510 & \\
\hline Personnel Jeep & 3 & 7.5 & 22.5 & 12 & 17 & 204 & \\
\hline Supply Motor & 4 & 80 & 320 & 12 & 239 & 2,868 & \\
\hline Bantam Duster & 4 & 30 & 120 & 12 & 89 & 1,068 & \\
\hline Trickle Duster & 6 & 10 & 40 & 18 & 30 & 540 & \\
\hline 42-in. Conveyor & 4 & 125 & 500 & 15 & 373 & 5,595 & \\
\hline 48-in. Conveyor & 2 & 150 & 300 & 18 & 224 & 4,032 & \\
\hline Ventilation Fans & 1 & 1000 & 1000 & 24 & 746 & 17,904 & \\
\hline Outside Electricals & & & 600 & 14 & 447 & 6,258 & \\
\hline Miscellaneous & & & 400 & 10 & 298 & 2,980 & \\
\hline & & & & & DTAL & 63,729 & $:$ \\
\hline
\end{tabular}

Power at $\$ 0.03$ per $\mathrm{kW}-\mathrm{h}$

Total Power Cost $=\frac{\$ 0.03}{\mathrm{~kW}-\mathrm{h}} \times \frac{63,729 \mathrm{~kW}-\mathrm{h}}{\text { day }} \times \frac{220 \text { days }}{\text { year }}=\frac{\$ 420,611.4}{\text { year }}$

Power Cost per Clean Ton $=\frac{\$ 420,611.4}{\text { year }} \times \frac{1 \text { year }}{1,136,652}=\frac{\$ 0.37}{\text { tons }}$ 
1980 LONGWALL CASES

\begin{tabular}{|c|c|c|c|c|c|c|c|}
\hline \multirow{2}{*}{$\begin{array}{l}\text { IDEAL CONDITIONS } \\
\text { Component }\end{array}$} & \multicolumn{5}{|c|}{ POWER COST } & \multicolumn{2}{|c|}{1980 DOLLARS } \\
\hline & No. & hp/Unit. & Total hp & h/day & $\mathrm{kW}$ & Total kW-h & Req. \\
\hline Longwall Unit & 1 & 625 & 625 & 12 & 466 & 5,592 & \\
\hline Continuous Miner & 2 & 600 & 1200 & 12 & 895 & 109,740 & \\
\hline MBC Unit & 2 & 120 & 240 & 12 & 179 & 2,148 & \\
\hline Roof Bolter & 4 & 50 & 200 & 7 & 149 & 1,043 & \\
\hline Auxiliary Fan & 3 & 15 & 45 & 18 & 34 & 612 & \\
\hline Mantrip Jeep & 5 & .15 & 75 & 4 & 56 & 224 & \\
\hline Mechanic Jeep & 3 & 15 & 45 & 15 & 34 & 510 & \\
\hline Personnel Jeep & 3 & 7.5 & 22.5 & 12 & 17 & 204 & \\
\hline Supply Motor & 3 & 80 & 240 & 12 & .179 & 2,148 & \\
\hline Bantam Duster & 3 & 30 & 90 & 12 & 67 & 804 & \\
\hline Trickle Duster & 4 & 10 & 40 & 18 & 30 & 540 & \\
\hline 42-in. Conveyor & 4 & 125 & 500 & 15 & 373 & $.5,595$ & \\
\hline 48-in. Conveyor & 2 & 150 & 300 & 18 & 224 & 4,032 & \\
\hline Ventilation Fans & 1 & 1000 & 1000 & 24 & 746 & 17,904 & \\
\hline Outside Electricals & & & 600 & 14 & 447 & 6,256 & \\
\hline Misce 11 aneous & & & 400 & 10 & 298 & 2,980 & \\
\hline : & & & & & TAL & 61,334 & \\
\hline
\end{tabular}

Power at $\$ 0.03$ per $\mathrm{kW}-\mathrm{h}$

Total Power Cost $=\frac{\$ 0.03}{\mathrm{~kW}-\mathrm{h}} \times \frac{61,334 \mathrm{~kW}-\mathrm{h}}{\text { day }} \times \frac{220 \text { days }}{\text { year }}=\frac{\$ 404,804.4}{\text { year }}$

Power Cost per $\mathrm{Clean}$ Ton $=\frac{\$ 404,804.4}{\text { year }} \times \frac{1 \text { year }}{2,309,802}=\frac{\$ 0.18}{\text { ton }}$ 


\begin{tabular}{|c|c|c|c|c|c|c|}
\hline \multirow{2}{*}{$\begin{array}{l}\text { AVERAGE CONDITIONS } \\
\text { Component }\end{array}$} & \multirow[b]{2}{*}{ No: } & \multicolumn{3}{|c|}{ POWER COST } & \multirow[b]{2}{*}{$\mathrm{kW}$} & 1980 DOLLAR \\
\hline & & hp/Unit & Total hp & h/day & & Total kW-h Req. \\
\hline Longwall Unit & 1 & 850 & 850 & 10 & 634 & 6,340 \\
\hline Continuous Miner & 3 & 600 & 1800 & 9 & 1342 & 12,078 \\
\hline MBC Unit & 3 & 120 & 360 & 9 & 268 & 2,412 \\
\hline Roof Bolter & 6 & 50 & 300 & 6 & 224 & 1,344 \\
\hline $\begin{array}{l}\text { Powered Temp. } \\
\text { Supports }\end{array}$ & 12 & 40 & 480 & 2. & 358 & 716 \\
\hline Ventilation system & 12 & 15 & 180 & 18 & 134 & 2,412 \\
\hline Mantrip Jeep & 6 & 15 & 90 & 4 & 67 & 268 \\
\hline Mechanic Jeep & 3 & 15 & $45^{\circ}$ & 15 & 34 & 510 \\
\hline Personnel Jeep & 3 & 7.5 & 22.5 & 12 & 17 & 204 \\
\hline Supply Motor & 4 & 80 & 320 & 12 & 239 & 2,868 \\
\hline Bantam Duster & 4 & 30 & 120 & 12 & 89 & 1,068 \\
\hline Trickle Duster. & 16 & 10 & 60 & 18 & 45 & 805 \\
\hline 42-in. Conveyor & 4 & 125 & 500 & 15 & 373 & 5,595 \\
\hline 48-in. Conveyor & 2 & 150 & 300 & 18 & 224 & 4,032 \\
\hline Ventilation Fans & 1 & 1000 & 1000 & 24 & 746 & 17,904 \\
\hline Outside Electricals & & & 600 & 14 & 447 & 6,258 \\
\hline Misce 11 aneous & & & 400 & 10 & 298 & 2,980 \\
\hline . & & & & & TOTAL & 67,794 \\
\hline
\end{tabular}

Power at $\$ 0.03$ per $\mathrm{kW}-\mathrm{h}$

Total Power Cost $=\frac{\$ 0.03}{\mathrm{~kW}-\mathrm{h}} \times \frac{67,794 \mathrm{~kW}-\mathrm{h}}{\text { day }} \times \frac{220 \text { days }}{\text { year }}=\frac{\$ 447,440.4}{\text { year }}$

Power Cost per $C l$ ean $\operatorname{Ton}=\frac{\$ 447,440.4}{\text { year }} \times \frac{1 \text { year }}{1,459,920}=\frac{\$ 0.31}{\text { ton }}$ 


\begin{tabular}{|c|c|c|c|c|c|c|}
\hline \multirow{2}{*}{$\begin{array}{l}\text { IDEAL CONDITIONS } \\
\text { Component }\end{array}$} & \multirow[b]{2}{*}{ No. } & \multicolumn{3}{|c|}{ POWER COST } & \multicolumn{2}{|r|}{1980 DOLLARS } \\
\hline & & hp/Unit & Total hp & $h /$ day & $\mathrm{kW}$ & Total kW-h Req. \\
\hline Longwall Unit & 1 & 850 & 850 & 12 & 634 & 7,608 \\
\hline Continuous Miner & 2 & 600 & 1200 & 12 & 895 & 10,740 \\
\hline MBC Unit & 2 & 120 & 240 & 12 & 179 & 2,148 \\
\hline Roof Bolter & 4 & 50 & 200 & 6 & 149 & 894 \\
\hline $\begin{array}{l}\text { Powered Temp. } \\
\text { Supports }\end{array}$ & 10 & 40 & 400 & 2 & 298 & 596 \\
\hline Ventilation System & 10 & 15 & 150 & 18 & 112 & 2,016 \\
\hline Mantrip Jeep & 5 & 15 & 75 & 4 & 56 & 2.24 \\
\hline Mechanic Jeep & 3 & 15 & 45 & 15 & 34 & 510 \\
\hline Personnel Jeep & 3 & 7.5 & 22.5 & 12 & 17 & 204 \\
\hline Supply Motor & 3 & 80 & 240 & 12 & 179 & 2,148 \\
\hline Bantam Duster & 3 & 30 & 90 & 12 & 67 & 804 \\
\hline Trickle Duster & 4 & 10 & 40 & 18 & 30 & 540 \\
\hline 42-in. Conveyor & 4 & 125 & 500 & 15 & 373 & 5,595 \\
\hline 48-in. Conveyor & 2 & 150 & 300 & 18 & 224 & 4,032 \\
\hline Ventilation Fans & 1 & 1000 & 1000 & 24 & 746 & 17,904 \\
\hline Outside Electricals & & & 600 & 14 & 447 & 6,258 \\
\hline Misce 11 aneous & & & 400 & 10 & 298 & 2,980 \\
\hline$\checkmark$ & & & & & TOTAL & 65,201 \\
\hline
\end{tabular}

Power at $\$ 0.03$ per $\mathrm{kW}-\mathrm{h}$

Total Power Cost $=\frac{\$ 0.03}{\mathrm{~kW}-\mathrm{h}} \times \frac{65,201 \mathrm{~kW}-\mathrm{h}}{\text { day }} \times \frac{220 \text { days }}{\text { year }}=\frac{\$ 430,326.6}{\text { year }}$

Power Cost per Clean Ton $=\frac{\$ 430,326.6}{\text { year }} \times \frac{1 \text { year }}{2,768,634}=\frac{\$ 0.16}{\text { ton }}$ 
SALARIED PERSONNEL REQUIREMENTS AND COSTS

\begin{tabular}{|c|c|c|c|c|c|c|c|c|c|c|}
\hline \multirow[b]{3}{*}{ Personne 1} & \multirow[b]{3}{*}{ Salary } & \multicolumn{4}{|c|}{1980 LONGWALL CASES } & & \multicolumn{4}{|c|}{2000 LONGWÁLL CASES } \\
\hline & & Average & Conditions & \multicolumn{3}{|c|}{ Ideal Conditions } & \multicolumn{2}{|c|}{ Average Conditions } & \multicolumn{2}{|r|}{ Ideal Conditions } \\
\hline & & Nc. & Yearly Total & No. & Yearly Total & & No. & Yearly Total & No. & Yearly Total \\
\hline Superintendent & $\$ 33,000$ & 1 & $\$ 33,000$ & 1 & $\$ 33,000$ & & 1 & $\$ 33,000$ & 1 & $\$ 33,000$ \\
\hline General Mine Foreman & 27,500 & 1 & 27,500 & 1 & 27,500 & & 1 & 27,500 & 1 & 27,500 \\
\hline Assist. Mine Foremar & 22,500 & 2 & 67,500 & 3 & 67,500 & , & 3 & 67,500 & 3 & 67,500 \\
\hline Section Foreman & 20,000 & 12 & 240,000 & 9 & 180,000 & & 12 & 240,000 & 9 & 180,000 \\
\hline Construction Foremar: & 21,000 & 11 & 231,000 & 23 & 483,000 & & 14 & 294,000 & 27 & 567,000 \\
\hline Longwa 11 Foreman & 22,000 & 1 & 22,000 & 1 & 22,000 & & 1 & 22,000 & 1 & 22,000 \\
\hline Haul age Foreman & 21,000 & 2 & 42,000 & 4 & 84,000 & & 2 & 42,000 & 5 & 105,000 \\
\hline Supply Foreman & 21,000 & 6 & 126,000 & 9 & 189,000 & & 6 & 126,000 & 9 & 189,000 \\
\hline Maint. Superintender:t & 22,500 & 1 & 22,500 & 1 & 22,500 & & 1 & 22,500 & 1 & 22,500 \\
\hline General Maint. Foreman & 20,000 & 3 & 60,000 & 3 & 60,000 & & 3 & 60,000 & 3 & 60,000 \\
\hline Shop Foreman & 20,000 & 3 & 60,000 & 3 & 60,000 & & 3 & 60,000 & 3 & 60,000 \\
\hline Chief Mine Engineer & 28,000 & 1 & 28,000 & 1 & 28,000 & & 1 & 28,000 & 1 & 28,000 \\
\hline Draftsman & 16,000 & 2 & 32,000 & 3 & 48,000 & & 2 & 32,000 & 3 & 48,000 \\
\hline Surveyors & 18,000 & 4 & 72,000 & 6 & 108,000 & & 4 & 72,000 & 6 & 108,000 \\
\hline Safety Director & 20,000 & 1 & 20,000 & 1 & 20,000 & & 1 & 20,000 & 1 & 20,000 \\
\hline Safety Inspector & $19 ., 000$ & 1 & 19,000 & 1 & 19,000 & & 1 & 19,000 & 1 & 19,000 \\
\hline Training Instructor & 18,000 & 1 & 18,000 & 1 & 18,000 & & 1 & 18,000 & 1 & 18,000 \\
\hline Noise/Dust Technician & 16,000 & 1 & 16,000 & 1 & 16,000 & & 1 & 16,000 & 1 & 16,000 \\
\hline Office Personnel Manager & 20,000 & 1 & 20,000 & 1 & 20,000 & & 1 & 20,000 & 1 & 20,000 \\
\hline Time/Bookk eeper & 16,000 & 1 & 16,000 & 1 & 16,000 & & 1 & 16,000 & 1 & 16,000 \\
\hline Warehouse Clerk & 14,000 & 3 & 42,000 & 3 & 42,000 & & 3. & 42,000 & 3 & 42,000 \\
\hline Industrial Engineer & 23,800 & 1 & 23,000 & 1 & 23,000 & & i & 23,000 & 1 & $23,800^{\circ}$ \\
\hline Electrical Engineer & 24,000 & 1 & 24,000 & 1 & 24,000 & & 1 & 24,000 & 1 & 24,000 \\
\hline Prep. Plant General Foreman & 25,000 & 1 & 25,000 & 1 & 25,000 & & 1 & 25,000 & 1 & 25,000 \\
\hline Prep. Plant Foremän & 20,000 & 3 & 60,000 & 3 & 60,000 & & 3 & 60,000 & 3 & 60,000 \\
\hline Control Systems Engineer & 27,000 & - & ------ & - & ------ & & 1 & 27,000 & 1 & 27,000 \\
\hline 1980 DOLLARS & TOTAL & 66 & $\$ 1,346,500$ & 83 & $\$ 1,695,500$ & & 70 & $\$ 1,436,500$ & 89 & $\$ 1,827,500$ \\
\hline Average Salary: per person & year & & $\$ 20,401$ & & $\$ 20,428$ & & & $\$ 20,521$ & & $\$ 20,534$ \\
\hline
\end{tabular}


1980 LONGWALL CASES

\begin{tabular}{|c|c|c|c|}
\hline \multirow{2}{*}{$\begin{array}{l}\text { AVERAGE CONDITIONS } \\
\text { Surface }\end{array}$} & \multicolumn{2}{|c|}{ HOURLY LABOR } & \multirow{2}{*}{$\begin{array}{l}\text { i980 DOLLARS } \\
\text { Daily Total }\end{array}$} \\
\hline & No. & Wages/Person/Day & \\
\hline $\begin{array}{l}\text { Conveyor Attendent } \\
\text { Electrician } \\
\text { Shop Mechanic } \\
\text { Shop Electrician } \\
\text { Supply Handler } \\
\text { Lampman } \\
\text { Warehouse Laborer } \\
\text { Prep. Plant Crew }\end{array}$ & $\begin{array}{r}3 \\
1 \\
6 \\
3 \\
6 \\
3 \\
3 \\
\frac{24}{49}\end{array}$ & $\begin{array}{r}\$ 68.05 \\
71.87 \\
71.87 \\
71.87 \\
67.47 \\
67.47 \\
67.47 \\
71.18\end{array}$ & $\begin{array}{r}\$ 204.15 \\
71.87 \\
431.22 \\
215.61 \\
404.82 \\
202.41 \\
202.41 \\
1,708.32 \\
\$ 3,440.81\end{array}$ \\
\hline \multicolumn{2}{|l|}{ Underground - General } & \multicolumn{2}{|l|}{. } \\
\hline $\begin{array}{l}\text { Motorman } \\
\text { Fireboss } \\
\text { Electrician } \\
\text { Mechanic } \\
\text { Scoop Operator } \\
\text { Pumper } \\
\text { Conveyor Attendants } \\
\text { Equipment Movers } \\
\text { Trackman } \\
\text { Greaser/Oiler } \\
\text { Mason } \\
\text { Laborer } \\
\text { Stopper Operator } \\
\text { Auxiliary Equip. Operators } \\
\quad \text { SUBTOTAL }\end{array}$ & $\begin{array}{r}12 \\
3 \\
3 \\
6 \\
3 \\
6 \\
6 \\
17 \\
17 \\
3 \\
6 \\
34 \\
2 \\
6 \\
124\end{array}$ & $\begin{array}{r}\$ 71.76 \\
79.72 \\
79.72 \\
79.72 \\
73.48 \\
71.18 \\
71.18 \\
71.76 \\
71.18 \\
71.18 \\
71.18 \\
71.18 \\
79.72 \\
79.72\end{array}$ & $\begin{array}{r}\$ 861.12 \\
239.16 \\
239.16 \\
478.32 \\
220.44 \\
427.08 \\
427.08 \\
1,219.92 \\
1,210.06 \\
213.54 \\
407.08 \\
2,420.12 \\
159.44 \\
478.32 \\
\$ 9,000.84\end{array}$ \\
\hline \multicolumn{4}{|c|}{ Underground - Continuous Miner Crew } \\
\hline $\begin{array}{l}\text { Miner Operator } \\
\text { Miner Helper } \\
\text { Mobile Bridge Carrier Operator } \\
\text { Roof Bolt Operator } \\
\text { Utility Person } \\
\text { Mechanic } \\
\text { SUBTOTAL }\end{array}$ & $\begin{array}{r}9 \\
9 \\
36 \\
18 \\
9 \\
\frac{9}{90}\end{array}$ & $\begin{array}{r}\$ 79.72 \\
76.48 \\
73.48 \\
79.72 \\
71.18 \\
79.72\end{array}$ & $\begin{array}{r}\$ 717.48 \\
688.32 \\
2,645.28 \\
-1,434.96 \\
640.62 \\
717.48 \\
\$ 6,844.14\end{array}$ \\
\hline \multicolumn{4}{|l|}{ Underground - Longwal1 Crew } \\
\hline $\begin{array}{l}\text { Shearer Operator } \\
\text { Support Operator } \\
\text { Headgate Attendant } \\
\text { Tailgate Attendant } \\
\text { Utility Person } \\
\text { Mechanic } \\
\text { SUBTOTAL }\end{array}$ & $\begin{array}{r}6 \\
6 \\
6 \\
6 \\
3 \\
\frac{6}{30}\end{array}$ & $\begin{array}{l}79.72 \\
79.72 \\
71.18 \\
71.18 \\
71.18 \\
79.72\end{array}$ & $\begin{array}{r}478.32 \\
478.32 \\
427.08 \\
427.08 \\
213.54 \\
478.32 \\
\$ 2,502.66\end{array}$ \\
\hline Hourly Total & 293 & & $\$ 21,788.45$ \\
\hline
\end{tabular}




\begin{tabular}{|c|c|c|c|}
\hline \multirow{2}{*}{$\begin{array}{l}\text { IDEAL CONDITIONS } \\
\text { Surface }\end{array}$} & \multicolumn{2}{|c|}{ HOURLY. LABOR } & \multirow{2}{*}{$\begin{array}{l}1980 \text { DOLLARS } \\
\text { Daily Total } \\
\end{array}$} \\
\hline & No. & Wages/Person/Day & \\
\hline $\begin{array}{l}\text { Conveyor Attendent } \\
\text { Electrician } \\
\text { Shop Mechanic } \\
\text { Shop Electrician } \\
\text { Supply Handler } \\
\text { Lampman } \\
\text { Warehouse Laborer } \\
\text { Prep. Plant Crew } \\
\text { SUBTOTAL }\end{array}$ & $\begin{array}{r}3 \\
1 \\
6 \\
3 \\
6 \\
3 \\
3 \\
\frac{30}{55}\end{array}$ & $\begin{array}{r}\$ 68.05 \\
71.87 \\
71.87 \\
71.87 \\
67.47 \\
67.47 \\
67.47 \\
71.78\end{array}$ & $\begin{array}{r}\$ 204.15 \\
71.87 \\
431.22 \\
215.61 \\
404.82 \\
202.41 \\
202.41 \\
2,135.40 \\
\$ 3,867.89\end{array}$ \\
\hline \multicolumn{4}{|l|}{ Underground - General } \\
\hline \begin{tabular}{l} 
Motorman \\
Fireboss \\
Electrician \\
Mechanic \\
Scoop Operator \\
Pumper \\
Conveyor Attendants \\
Equipment Movers \\
Trackman \\
Greaser/Oiler \\
Mason \\
Laborer \\
Stopper Operator \\
Auxiliary Equip. Operators \\
\multicolumn{2}{c}{ SUBTOTAL }
\end{tabular} & $\begin{array}{r}12 \\
3 \\
3 \\
6 \\
3 \\
11 \\
6 \\
34 \\
34 \\
3 \\
11 \\
69 \\
2 \\
11 \\
208\end{array}$ & $\begin{array}{r}\$ 71.76 \\
79.72 \\
79.72 \\
79.72 \\
73.48 \\
71.18 \\
71.18 \\
71.76 \\
71.18 \\
71.18 \\
71.18 \\
71.18 \\
79.72 \\
79.7 ?\end{array}$ & $\begin{array}{r}\$ 861.12 \\
239.16 \\
239.16 \\
478.32 \\
220.44 \\
782.98 \\
427.08 \\
2,439.84 \\
2,420.12 \\
213.54 \\
782.98 \\
4,911.42 \\
159.44 \\
876.92 \\
\$ 15,052.52\end{array}$ \\
\hline \multicolumn{4}{|c|}{ Underground - Continuous Miner Crew } \\
\hline $\begin{array}{l}\text { Miner Operator } \\
\text { Miner Helper } \\
\text { Mobile Bridge Carrier Operator } \\
\text { Roof Bolt Operator } \\
\text { Utility Person } \\
\text { Mechanic } \\
\text { SUBTOTAL }\end{array}$ & $\begin{array}{r}6 \\
6 \\
24 \\
12 \\
6 \\
\frac{6}{60}\end{array}$ & $\begin{array}{r}\$ 79.72 \\
76.48 \\
73.48 \\
79.72 \\
71.18 \\
79.72\end{array}$ & $\begin{array}{r}\$ 478.32 \\
458.88 \\
1,763.52 \\
956.64 \\
427.08 \\
478.32 \\
\$ 4,562.76\end{array}$ \\
\hline \multicolumn{4}{|l|}{ Underground - Longwal1 Crew } \\
\hline $\begin{array}{l}\text { Shearer Operator } \\
\text { Support Operator } \\
\text { Headgate Attendant } \\
\text { Tailgate Attendant } \\
\text { Utility Person } \\
\text { Mechanic } \\
\text { SUBTOTAL }\end{array}$ & $\begin{array}{r}6 \\
6 \\
6 \\
6 \\
3 \\
\frac{6}{30}\end{array}$ & $\begin{array}{l}79.72 \\
79.72 \\
71.18 \\
71.18 \\
71.18 \\
79.72\end{array}$ & $\begin{array}{r}478.32 \\
478.32 \\
427.08 \\
427.08 \\
213.54 \\
478.32 \\
\$ 2,502.66\end{array}$ \\
\hline Hourly Total & 353 & & $\$ 25,985.83$ \\
\hline
\end{tabular}




\begin{tabular}{|c|c|c|c|}
\hline \multirow{2}{*}{$\begin{array}{l}\text { AVERAGE CONDITIONS } \\
\text { Surface }\end{array}$} & \multicolumn{2}{|c|}{ HOURLY LABOR } & \multirow{2}{*}{$\begin{array}{l}1980 \text { DOLLARS } \\
\text { Daily Total } \\
\end{array}$} \\
\hline & No. & Wages/Person/Day & \\
\hline $\begin{array}{l}\text { Conveyor Attendent } \\
\text { Electrician } \\
\text { Shop Mechanic } \\
\text { Shop Electrician } \\
\text { Supply Handler } \\
\text { Lampman } \\
\text { Warehouse Laborer } \\
\text { Prep. Plant Crew }\end{array}$ & $\begin{array}{r}3 \\
1 \\
6 \\
3 \\
6 \\
3 \\
3 \\
\frac{24}{49}\end{array}$ & $\begin{array}{r}\$ 68.05 \\
71.87 \\
71.87 \\
71.87 \\
67.47 \\
67.47 \\
67.47 \\
71.18\end{array}$ & $\begin{array}{r}\$ 204.15 \\
71.87 \\
431.22 \\
215.61 \\
404.82 \\
202.41 \\
202.41 \\
1,708.32 \\
\$ 3,440.81\end{array}$ \\
\hline \multicolumn{4}{|l|}{ Underground - General } \\
\hline $\begin{array}{l}\text { Motorman } \\
\text { Fireboss } \\
\text { Electrician } \\
\text { Mechanic } \\
\text { Scoop Operator } \\
\text { Pumper } \\
\text { Conveyor Attendants } \\
\text { Equipment Movers } \\
\text { Trackman } \\
\text { Greaser/Oiler } \\
\text { Mason } \\
\text { Laborer } \\
\text { Stopper Operator } \\
\text { Auxiliary Equip. Operators } \\
\quad \text { SUBTOTAL }\end{array}$ & $\begin{array}{r}12 \\
3 \\
3 \\
6 \\
3 \\
7 \\
6 \\
22 \\
22 \\
3 \\
7 \\
43 \\
2 \\
7 \\
146\end{array}$ & $\begin{array}{r}\$ 71.76 \\
79.72 \\
79.72 \\
79.72 \\
73.48 \\
71.18 \\
71.18 \\
71.76 \\
71.18 \\
71.18 \\
71.18 \\
71.18 \\
79.72 \\
79.72\end{array}$ & $\begin{array}{r}\$ 861.12 \\
239.16 \\
239.16 \\
478.32 \\
220.44 \\
498.26 \\
427.08 \\
1,578.72 \\
1,565.96 \\
213.54 \\
498.26 \\
3,060.74 \\
159.44 \\
558.04 \\
\$ 10,598.24\end{array}$ \\
\hline \multicolumn{4}{|c|}{ Underground - Continuous Miner Crew } \\
\hline $\begin{array}{l}\text { Miner Operator } \\
\text { Miner Helper } \\
\text { Mobile Bridge Carrier Operator } \\
\text { Roof Bolt Operator } \\
\text { Utility Person } \\
\text { Mechanic } \\
\text { Mobile TRS Operator } \\
\text { SUBTOTAL }\end{array}$ & $\begin{array}{r}9 \\
9 \\
9 \\
36 \\
9 \\
9 \\
9 \\
90\end{array}$ & $\begin{array}{r}\$ 79.72 \\
76.48 \\
73.48 \\
79.72 \\
71.18 \\
79.72 \\
79.72\end{array}$ & $\begin{array}{r}\$ 717.48 \\
688.32 \\
661.32 \\
2,869.92 \\
640.62 \\
717.48 \\
717.48 \\
\$ 7,012.62\end{array}$ \\
\hline \multicolumn{4}{|l|}{ Underground - Longwall Crew } \\
\hline $\begin{array}{l}\text { Cutting Technician } \\
\text { Support Technician } \\
\text { Headgate Attendant } \\
\text { Tailgate Attendant } \\
\text { Utility Person } \\
\text { Mechanic } \\
\text { Control System Technician } \\
\text { SUBTOTAL }\end{array}$ & $\begin{array}{r}3 \\
6 \\
6 \\
6 \\
3 \\
6 \\
3 \\
33\end{array}$ & $\begin{array}{l}79.72 \\
79.72 \\
71.18 \\
71.18 \\
71.18 \\
79.72 \\
79.72\end{array}$ & $\begin{array}{r}239.16 \\
478.32 \\
427.08 \\
427.08 \\
213.54 \\
478.32 \\
239.16 \\
\$ 2,502.66\end{array}$ \\
\hline Hourly Total & 318 & & $\$ 23,554.33$ \\
\hline
\end{tabular}




\begin{tabular}{|c|c|c|c|}
\hline \multirow{2}{*}{$\begin{array}{l}\text { IDEAL CONDITIONS } \\
\text { Surface }\end{array}$} & \multicolumn{2}{|c|}{ HOURI.Y LABOR } & \multirow{2}{*}{$\begin{array}{l}1980 \text { DOLLARS } \\
\text { Daily Total }\end{array}$} \\
\hline & No. & Wages/Person/Day & \\
\hline $\begin{array}{l}\text { Conveyor Attendent } \\
\text { Electrician } \\
\text { Shop Mechanic } \\
\text { Shop Electrician } \\
\text { Supply Handler } \\
\text { Lampman } \\
\text { Warehouse Laborer } \\
\text { Prep. Plant Crew } \\
\end{array}$ & $\begin{array}{r}3 \\
1 \\
6 \\
3 \\
6 \\
3 \\
3 \\
\frac{30}{55}\end{array}$ & $\begin{array}{r}\$ 68.05 \\
71.87 \\
71.87 \\
71.87 \\
67.47 \\
67.47 \\
67.47 \\
71.18\end{array}$ & $\begin{array}{r}\$ 204.15 \\
71.87 \\
431.22 \\
215.61 \\
404.82 \\
202.41 \\
202.41 \\
2,135.40 \\
\$ 3,867.89\end{array}$ \\
\hline \multicolumn{4}{|l|}{ Underground - General } \\
\hline \begin{tabular}{l} 
Motorman \\
Fireboss \\
Electrician \\
Mechanic \\
Scoop Operator \\
Pumper \\
Conveyor Attendants \\
Equipment Movers \\
Trackman \\
Greaser/Oiler \\
Mason \\
Laborer \\
Stopper Operator \\
Auxiliary Equip. Operators \\
\multicolumn{2}{c}{ SUBTOTAL, }
\end{tabular} & $\begin{array}{r}12 \\
3 \\
3 \\
6 \\
3 \\
14 \\
6 \\
41 \\
41 \\
3 \\
14 \\
82 \\
2 \\
14 \\
244\end{array}$ & $\begin{array}{r}\$ 71.76 \\
79.72 \\
79.72 \\
79.72 \\
73.48 \\
71.18 \\
71.18 \\
71.76 \\
71.18 \\
71.18 \\
71.18 \\
71.18 \\
79.72 \\
79.72\end{array}$ & $\begin{array}{r}\$ 861.12 \\
239.16 \\
239.16 \\
478.32 \\
220.44 \\
996.52 \\
427.08 \\
2,942.16 \\
2,918.38 \\
213.54 \\
996.52 \\
5,836.76 \\
159.44 \\
1116.08 \\
\$ 17,644.68\end{array}$ \\
\hline \multicolumn{4}{|c|}{ Underground - Continuous Miner Crew } \\
\hline $\begin{array}{l}\text { Miner Operator } \\
\text { Miner Helper } \\
\text { Mobile Bridge Carrier Operator } \\
\text { Roof Bolt Operator } \\
\text { Utility Person } \\
\text { Mechanic } \\
\text { Mobile TRS Operator } \\
\text { SUBTOTAL }\end{array}$ & $\begin{array}{r}6 \\
6 \\
6 \\
24 \\
6 \\
6 \\
\frac{6}{60}\end{array}$ & $\begin{array}{r}\$ 79.72 \\
76.48 \\
73.48 \\
79.72 \\
71.18 \\
79.72 \\
79.72\end{array}$ & $\begin{array}{r}\$ 478.32 \\
458.88 \\
440.88 \\
1913.28 \\
427.08 \\
478.32 \\
478.32 \\
\$ 4,675.08\end{array}$ \\
\hline \multicolumn{4}{|l|}{ Underground - Longwa11 Crew } \\
\hline $\begin{array}{l}\text { Cutting Technician } \\
\text { Support Technician } \\
\text { Headgate Attendant } \\
\text { Tailgate Attendant } \\
\text { Utility Person } \\
\text { Mechanic } \\
\text { Control System Technician } \\
\text { SUBTOTAL }\end{array}$ & $\begin{array}{l}3 \\
6 \\
6 \\
6 \\
3 \\
6 \\
\frac{3}{33}\end{array}$ & $\begin{array}{l}79.72 \\
79.72 \\
71.18 \\
71.18 \\
71.18 \\
79.72 \\
79.72\end{array}$ & $\begin{array}{r}239.16 \\
478.32 \\
427.08 \\
427.08 \\
213.54 \\
478.32 \\
239.16 \\
\$ 2,502.66\end{array}$ \\
\hline Hourly Total & 392 & & $\$ 28,690.31$ \\
\hline
\end{tabular}




\begin{tabular}{|c|c|c|c|c|}
\hline & \multicolumn{2}{|c|}{1980 SHORTWALL CASES } & \multicolumn{2}{|c|}{2000 SHORTWALL CASES } \\
\hline & $\begin{array}{l}\text { Average } \\
\text { Conditions }\end{array}$ & $\begin{array}{l}\text { Ideal } \\
\text { Conditions }\end{array}$ & $\begin{array}{l}\text { Average } \\
\text { Conditions }\end{array}$ & $\begin{array}{l}\text { Ideal } \\
\text { Conditions }\end{array}$ \\
\hline TPMS: & & & & \\
\hline $\begin{array}{l}\text { Pane } 1 \text { Deve lopment: } \\
\text { Shortwall Production: } \\
\text {. } \\
\text { Tons per Panel: }\end{array}$ & $\begin{array}{l}460 \\
570\end{array}$ & $\begin{array}{l}1440 \\
1350\end{array}$ & $\begin{array}{l}550 \\
740\end{array}$ & $\begin{array}{l}1510 \\
1580\end{array}$ \\
\hline $\begin{array}{l}\text { Deve lopment: } \\
\text { Production: }\end{array}$ & $\begin{array}{r}69,039 \text { tons } \\
123,012 \text { tons }\end{array}$ & & $\begin{array}{r}69,039 \text { tons } \\
123,012 \text { tons }\end{array}$ & $\cdot$ \\
\hline Shifts to Mine One Panel: & & & & 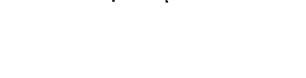 \\
\hline $\begin{array}{l}\text { Development: } \\
\text { Production: } \\
\text { Shifts to Move to Next Pane 1: }\end{array}$ & $\begin{array}{r}150.08 \\
215.81 \\
\end{array}$ & $\begin{array}{l}47.94 \\
91.12\end{array}$ & $\begin{array}{l}125.52 \\
166.23\end{array}$ & $\begin{array}{l}45.72 \\
77.86\end{array}$ \\
\hline $\begin{array}{l}\text { Deve lopment: } \\
\text { Production: }\end{array}$ & $\begin{array}{r}4 \\
20\end{array}$ & $\begin{array}{r}4 \\
20\end{array}$ & $\begin{array}{r}4 \\
\therefore \quad 20\end{array}$ & $\begin{array}{r}4 \\
20\end{array}$ \\
\hline Total Shifts per Pane l: & & & & \\
\hline $\begin{array}{l}\text { Deve lopment: } \\
\text { Production: }\end{array}$ & $\begin{array}{l}154.08 \\
235.81\end{array}$ & $\begin{array}{r}51.94 \\
111.12\end{array}$ & $\begin{array}{l}129.52 \\
186.23\end{array}$ & $\begin{array}{l}49.72 \\
97.86\end{array}$ \\
\hline Modified TPMS: & & & & \\
\hline $\begin{array}{l}\text { Deve lopment: } \\
\text { Production: }\end{array}$ & $\begin{array}{l}448.07(450) \\
521.66(520)\end{array}$ & $\begin{array}{l}1329.21(i 330) \\
1107.02(1110)\end{array}$ & $\begin{array}{l}533.04(530) \\
660.53(660)\end{array}$ & $\begin{array}{l}1388.55(1390) \\
1257.08(1260)\end{array}$ \\
\hline
\end{tabular}




\section{Design Capacity $=$}

$[(N(d) \times \operatorname{TPMS}(d))+(N(P) \times \operatorname{TPMS}(P))] S \times D \times(1-R)$

N (d) = Number of development units per shift

TPMS $(d)=$ Productivity of development units

$N(P)=$ Number of productions per shift

TPMS $(P)=$ Productivity of production units

$S=$ Shifts per day

$D=$ Days per week

$R=$ Reject precentage

\begin{tabular}{|c|c|c|c|c|}
\hline & \multicolumn{2}{|c|}{1980 SHORTWALL } & \multicolumn{2}{|c|}{2000 SHORTWALL } \\
\hline & $\begin{array}{l}\text { Average } \\
\text { Conditions }\end{array}$ & Ideal & $\begin{array}{l}\text { Average } \\
\text { Conditions }\end{array}$ & $\begin{array}{c}\text { Ideal } \\
\text { Conditions }\end{array}$ \\
\hline$N(d)$ & 3 & 2 & 3 & 2 \\
\hline TPMS（d） & 450 & 1330 & 530 & 1390 \\
\hline$N(P)$ & 1 & 1 & 1 & 1 \\
\hline TPMS (P) & 520 & 1110 & 660 & 1260 \\
\hline s & 3 & 3 & 3 & 3 \\
\hline D & 220 & 220 & 220 & 220 \\
\hline $\mathbf{R}$ & $25 \%$ & $25 \%$ & $25 \%$ & $25 \%$ \\
\hline $\begin{array}{l}\text { Design } \\
\text { Capacity in } \\
\text { clean tons }\end{array}$ & 925,650 & $1,866,150$ & $1,113,750$ & $1,999,800$ \\
\hline
\end{tabular}


Equipment Cost

1980 Dollars

\section{Continuous Miner Development Units \\ Average Conditions: Same as longwall case $\$ 3,171,000$ for three units \\ Ideal Conditions: Same as longwall case $\$ 2,213,900$}

Shortwall Production Unit - Average and Ideal Conditions No. Cost/Unit Total Cost

Continuous Miner

MBC Unit

Roof Bolter

Support, Pumps, etc. (1)

Scoop with Batteries \& Charger

Bantam Duster

Trickle Duster

Section Power Center \& Cables

Parts Car

Oil Storage Car

Section Tools

Section Welder

Section Haulage Belt (42 in. $x 3000 \mathrm{ft}$ )

Fire Suppression
$1 \$ 412,000$

1242,000

$1 \quad 76,700$

lot $1,245,240$

1

1

2

1

1

1

1

1

1

1

$\$ 42.5 / \mathrm{ft}$

4,200

TOTAL
$\$ 412,000$

242,000

76,700

$1,245,240$

77,200

18,000

30,000

53, 000

10,500

12,000

7,700

1,700

255,000

4,200

1. Cost is updated from "Analysis of United States Shortwall Mining Practice", Mining Congress Journal, Katen, Kenneth P., January 1979. Update factor from IOM FF-345-79-239 (P. G. Gordon), JPL, $12 / 17 / 79$. 
Development Units:

- Same as 2000 Longwall case

- 3 units

- $\$ 5,218,900$

Shortwal1 Unit:

- Same as 1980 case except for shortwall supports

- 1978 shortwal1 supports, 5-ft stroke, $\$ 6,000 / \mathrm{ft}$

- 2000 shortwall supports, 7-ft stroke, $\$ 8000 / \mathrm{ft}$

- 180-ft face

- 2000 supports $=\$ 1,440,000$

- 1978 supports $=\$ 1,245,240$

- Total unit cost in $1980=\$ 2,445,240$

- Unit cost in $2000=\$ 2,445,240-\$ 1,245,240+\$ 1,440,000$

$=\$ 2,640,000$

Ideal Conditions

Equipment Cost

1980 Dollars

Development Units:

- Same as 2000 longwall case

- 2 units

$-\$ 3,671,900$

Shortwal1 Unit:

- Same as 2000 shortwal1, average conditions case

- $\$ 2,640,000$ 
"1980" SHORTWALL CASES

Average Conditions

Equipment Cost

1980 Dollars

Power consumption for shortwall unit assumed to be the same as for a development unit in U.S. Bureau of Mines IC 8757 ; 1977, Green, L. E. and Palowitch, E. R., Comparative Shortwall and Room-and-Pillar Mining Costs.

Therefore, the 1980 Longwa11 Development Power Consumption was modified for shortwall.

All consumption remains the same except that associated directly with development equipment - continuous miner, MBC unit, roof bolter, and trickle duster. The consumption of these components was increased by $33 \%$ to account for the shortwall unit.

Total power consumption for 1980 shortwall, average conditions is therefore $64,513 \mathrm{~kW}-\mathrm{h}$ per day.

$$
\$ 0.46 \text { per clean ton }
$$

The same approach was taken as in the average conditions case: Therefore, total power consumption is $62,977 \mathrm{~kW}-\mathrm{h}$ per day.

CLEAN: $\quad 62,977 \frac{\mathrm{kW}-\mathrm{h}}{\mathrm{day}} \times 220 \frac{\text { day }}{\text { year }} \times \frac{\$ 0.03}{\mathrm{~kW}-\mathrm{h}} \times \frac{1 \text { year }}{1,866,150 \text { clean tons }}=\frac{\$ 0.22}{\text { ton }}$ 
Power requirements adapted from longwall case. Assumed that a shortwall unit consumed as much power as a development unit. Therefore, components directly related to development units were inflated by factor of 1.33 to account for shortwall consumption.

$\underline{\mathrm{kW}-\mathrm{h}}$

Continuous Miner

16,064

MBC Unit

3,208

Roof Bolter

Temporary Roof Supports

1,788

Ventilation System

716

Jeeps

2,412

.982

Supply Motor

2,868

Dusters

42-in. Conveyors

2,139

5,595

48-in. Conveyors

4,832

Ventilation Fan

17,904

Outside Electricals \& Miscellaneous

$\frac{9,238}{66,946}$

$\frac{9}{66,946} \mathrm{~kW}-\mathrm{h}$

Per clean ton: $\frac{\$ 0.03}{\mathrm{~kW}-\mathrm{h}} \times 66,946 \frac{\mathrm{kW}-\mathrm{h}}{\mathrm{day}} \times 220$ days $\times \frac{1 \text { year }}{1,113,750 \text { tons }}=\$ 0.40 /$ ton

Average Conditions

Power Cost

1980 Dollars

Same assumptions as average conditions case.

.

$\underline{\mathrm{kW}-\mathrm{h}}$

Continuous Miner

16,110

MBC Unit

3,222

Roof Bolter

Temporary Roof Supports

1,341

Ventilation System

596

Jeeps

2,016

Supply'Motor

938

2,148

Dusters

1,614

Conveyors

9,627

Ventilation Fans

17,904

Outside Electricals \& Miscellaneous

9,238

$\frac{1,546}{6 W-h}$

Per clean ton: $\frac{\$ 0.03}{\mathrm{~kW}-\mathrm{h}} \times 64,754 \frac{\mathrm{kW}-\mathrm{h}}{\mathrm{day}} \times 220$ days $\times \frac{1 \text { year }}{1,999,800 \text { tons }}=\$ 0.21 /$ ton 
SALARIED PERSONNEL REQUIREMENTS AND COSTS

\begin{tabular}{|c|c|c|c|c|c|c|c|c|c|}
\hline \multirow[b]{3}{*}{ Personne 1} & \multirow[b]{3}{*}{ Salary } & \multicolumn{4}{|c|}{1980 SHORTWALL CASES } & \multicolumn{4}{|c|}{2000 SHORTWALL CASES } \\
\hline & & Average & Conditions & \multicolumn{2}{|c|}{ Ideal Conditions. } & \multicolumn{2}{|c|}{ Average Conditions } & \multicolumn{2}{|r|}{ Ideal Conditions } \\
\hline & & No. & Yearly Total & No. & Yearly Total & No. & Yearly Total & No. & Yearly Total \\
\hline Superintendent & $\$ 33,000$ & 1 & $\$ 33,000$ & 1 & $\$ 33,000$ & 1 & $\$ 33,000$ & 1 & $\$ 33,000$ \\
\hline General Mine Foreman & 27,500 & 1 & 27,500 & 1 & 27,500 & 1 & 27,500 & 1 & 27,500 \\
\hline Assist. Mine Foreman & 22,500 & 3 & 67,500 & 3 & 67,500 & 3 & 67,500 & 3 & 67,500 \\
\hline Section Foreman & 20,000 & 12 & 240,000 & 9 & 180,000 & 12 & 240,000 & 9 & 180,000 \\
\hline Construction Foreman & 21,000 & 10 & 210,000 & 19 & 399,000 & 12 & 252,000 & 21 & 441,000 \\
\hline Shortwall Foreman & 22,000 & 1 & 22,000 & 1 & 22,000 & 1 . & 22,000 & 1 & 22,000 \\
\hline Hau lage Foreman & 21,000 & 2 & 42,000 & 3 & 63,000 & 2 & 42,000 & 3 & 63,000 \\
\hline Supply Foreman & 21,000 & 3 & 63,000 & 6 & 126,000 & 6 & 126,000 & 6 & 126,000 \\
\hline Ma int. Superintendent & 22,500 & 1 & 22,500 & 1 & 22,500 & 1 & 22,500 & 1 & 22,500 \\
\hline General Maint. Foreman & 20,000 & 3 & 60,000 & 3 & 60,000 & 3 & 60,000 & 3 & 60,000 \\
\hline Shop Foreman & 20,000 & 3 & 60,000 & 3 & 60,000 & 3 & 60,000 & 3 & 60,000 \\
\hline Chief Mine Engineer & 28,000 & 1 & 28,000 & 1 & 28,000 & 1 & 28,000 & 1 & 28,000 \\
\hline Draftsman & 16,000 & 1 & 16,000 & 2 & 32,000 & 2 & 32,000 & 2 & 32,000 \\
\hline Surveyors & 18,000 & 2. & 36,000 & 4 & 72,000 & 4 & 72,000 & 4 & 72,000 \\
\hline Sa fety Director & 20,000 & 1 & 20,000 & 1 & 20,000 & 1 & 20,000 & 1 & 20,000 \\
\hline Safety Inspector & 19,000 & 1 & 19,000 & 1 & 19,000 & 1 & 19,000 & 1 & 19,000 \\
\hline Training Instructor & 18,000 & 1 & 18,000 & 1 & 18,000 & 1 & 18,000 & 1 & 18,000 \\
\hline Noise/Dust Technician & 16,000 & 1 & 16,000 & 1 & 16,000 & 1 & 16,000 & 1 & 16,000 \\
\hline Office Personnel Manager & 20,000 & 1 & 20,000 & 1 & 20,000 & 1 & 20,000 & 1 & 20,000 \\
\hline Time/Bookk eeper & 16,000 & 1 & 16,000 & 1 & 16,000 & 1 & 16,000 & 1 & 16,000 \\
\hline Warehouse $\mathrm{Clerk}$ & 14,000 & 3 & 42,000 & 3 & 42,000 & 3 & 42,000 & 3 & 42,000 \\
\hline Industrial Engineer & 23,000 & 1 & 23,000 & 1 & 23,000 & 1 & 23,000 & 1 & 23,800 \\
\hline Electrical Engineer & 24,000 & 1 & 24,000 & 1 & 24,000 & 1 & 24,000 & 1 & 24,000 \\
\hline Prep. Plant General Foreman & 25,000 & 1 & 25,000 & 1 & 25,000 & 1 & 25,000 & 1 & 25,000 \\
\hline Prep. Plant Foreman & 20,000 & 3 & 60,000 & 3 & 60,000 & 3 & 60,000 & 3 & 60,000 \\
\hline Control Systems Engineer & 27,000 & - & ----- & - & -.-- & 1 & 27,000 & 1 & 27,000 \\
\hline 1980 DOLLARS & TOTAL & 66 & $\$ 1,210 ; 500$ & 83 & $\$ 1,475,500$ & 68 & $\$ 1,394,500$ & 75 & $\$ 1,544,500$ \\
\hline Average Salary: per person & per year & & $\$ 20,517$ & & $\$ 20,493$ & & $\$ 20,507$ & & $\$ 20,593$ \\
\hline
\end{tabular}


1980 SHORTWALL CASES

\begin{tabular}{|c|c|c|c|}
\hline \multirow{2}{*}{$\begin{array}{l}\text { AVERAGE CONDITIONS } \\
\text { Surface }\end{array}$} & \multicolumn{2}{|c|}{ HOURLY LABOR } & \multirow{2}{*}{$\frac{1980 \text { DOLLARS }}{\text { Daily Total }}$} \\
\hline & No. & Wages/Person/Day & \\
\hline $\begin{array}{l}\text { Conveyor Attendent } \\
\text { Electrician } \\
\text { Shop Mechanic } \\
\text { Shop Electrician } \\
\text { Supply Handler } \\
\text { Lampman } \\
\text { Warehouse Laborer } \\
\text { Prep. Plant Crew } \\
\text { SUBTOTAL }\end{array}$ & $\begin{array}{r}3 \\
1 \\
6 \\
3 \\
6 \\
3 \\
3 \\
18 \\
43\end{array}$ & $\begin{array}{r}\$ 68.05 \\
71.87 \\
71.87 \\
71.87 \\
67.47 \\
67.47 \\
67.47 \\
71.18\end{array}$ & $\begin{array}{r}\$ 204.15 \\
71.87 \\
431.22 \\
215.61 \\
404.82 \\
202.41 \\
202.41 \\
1,281.24 \\
\$ 3,013.73\end{array}$ \\
\hline \multicolumn{4}{|l|}{ Underground - General } \\
\hline $\begin{array}{l}\text { Motorman } \\
\text { Fireboss } \\
\text { Electrician } \\
\text { Mechanic } \\
\text { Scoop Operator } \\
\text { Pumper } \\
\text { Conveyor Attendants } \\
\text { Equipment Movers } \\
\text { Trackman } \\
\text { Greaser/Oiler } \\
\text { Mason } \\
\text { Laborer } \\
\text { Stopper Operator } \\
\text { Auxiliary Equip. Operators } \\
\end{array}$ & $\begin{array}{r}12 \\
3 \\
3 \\
6 \\
3 \\
5 \\
6 \\
14 \\
14 \\
3 \\
5 \\
29 \\
2 \\
5 \\
110\end{array}$ & $\begin{array}{r}\$ 71.76 \\
79.72 \\
79.72 \\
79.72 \\
73.48 \\
71.18 \\
71.18 \\
71.76 \\
71.18 \\
71.18 \\
71.18 \\
71.18 \\
79.72 \\
79.72\end{array}$ & $\begin{array}{r}\$ 861.12 \\
239.16 \\
239.16 \\
478.32 \\
220.44 \\
355.90 \\
427.08 \\
1,004.64 \\
996.52 \\
213.54 \\
355.90 \\
2,064.22 \\
159.44 \\
398.60 \\
\$ 8,014.04\end{array}$ \\
\hline \multicolumn{4}{|c|}{ Underground - Continuous Miner Crew } \\
\hline $\begin{array}{l}\text { Miner Operator } \\
\text { Miner Helper } \\
\text { Mobile Bridge Carrier Operator } \\
\text { Roof Bolt Operator } \\
\text { Utility Person } \\
\text { Mechanic } \\
\quad \text { SUBTOTAL }\end{array}$ & $\begin{array}{r}9 \\
9 \\
36 \\
18 \\
9 \\
\frac{9}{90}\end{array}$ & $\begin{array}{r}\$ 79.72 \\
76.48 \\
73.48 \\
79.72 \\
71.18 \\
79.72\end{array}$ & $\begin{array}{r}\$ 717.48 \\
688.32 \\
2,645.28 \\
1,434.96 \\
640.62 \\
717.48 \\
\$ 6,844.14\end{array}$ \\
\hline \multicolumn{4}{|l|}{ Underground - Shortwall Crew } \\
\hline $\begin{array}{l}\text { Miner Operator } \\
\text { Miner Helper } \\
\text { MBC Operator } \\
\text { Chock Operator } \\
\text { Mechanic } \\
\text { Utility Person }\end{array}$ & $\begin{array}{l}3 \\
3 \\
6 \\
6 \\
3 \\
\frac{3}{24}\end{array}$ & $\begin{array}{l}79.72 \\
79.72 \\
73.48 \\
79.72 \\
79.72 \\
71.18\end{array}$ & $\begin{array}{r}239.16 \\
229.44 \\
440.88 \\
478.32 \\
239.16 \\
213.54 \\
\$ 1,840.50\end{array}$ \\
\hline Hourly Total & 267 & & $\$ 23,176.83$ \\
\hline
\end{tabular}




\section{SHORTWALL CASES}

\begin{tabular}{|c|c|c|c|}
\hline \multirow{2}{*}{$\begin{array}{l}\text { IDEAL CONDITIONS } \\
\text { Surface }\end{array}$} & \multicolumn{2}{|c|}{ HOURLY LABOR } & \multirow{2}{*}{$\frac{1980 \text { DOLLARS }}{\text { Daily Total }}$} \\
\hline & No. & Wages/Person/Day & \\
\hline $\begin{array}{l}\text { Conveyor Attendent } \\
\text { Electrician } \\
\text { Shop Mechanic } \\
\text { Shop Electrician } \\
\text { Supply Handler } \\
\text { Lampman } \\
\text { Warehouse Laborer } \\
\text { Prep. Plant Crew }\end{array}$ & $\begin{array}{r}3 \\
1 \\
6 \\
3 \\
6 \\
3 \\
3 \\
\frac{24}{49}\end{array}$ & $\begin{array}{r}\$ 68.05 \\
71.87 \\
71.87 \\
71.87 \\
67.47 \\
67.47 \\
67.47 \\
71.18\end{array}$ & $\begin{array}{r}\$ 204.15 \\
71.87 \\
431.22 \\
215.61 \\
404.82 \\
202.41 \\
202.41 \\
1,708.32 \\
\$ 3,440.81\end{array}$ \\
\hline Underground - General & & & \\
\hline $\begin{array}{l}\text { Motorman } \\
\text { Fireboss } \\
\text { Electrician } \\
\text { Mechanic } \\
\text { Scoop Operator } \\
\text { Pumper } \\
\text { Conveyor Attendants } \\
\text { Equipment Movers } \\
\text { Trackman } \\
\text { Greaser/Oiler } \\
\text { Mason } \\
\text { Laborer } \\
\text { Stopper Operator } \\
\text { Auxiliary Equip. Operators } \\
\quad \text { SUBTOTAL }\end{array}$ & $\begin{array}{r}12 \\
3 \\
3 \\
6 \\
3 \\
10 \\
6 \\
29 \\
29 \\
3 \\
10 \\
58 \\
2 \\
10 \\
184\end{array}$ & $\begin{array}{r}\$ 71.76 \\
79.72 \\
79.72 \\
79.72 \\
73.48 \\
71.18 \\
71.18 \\
71.76 \\
71.18 \\
71.18 \\
71.18 \\
71.18 \\
79.72 \\
79.72\end{array}$ & $\begin{array}{r}\$ 861.12 \\
239.16 \\
239.16 \\
478.32 \\
220.44 \\
711.80 \\
427.08 \\
2,081.04 \\
2,064.22 \\
213.54 \\
711.80 \\
4,128.44 \\
159.44 \\
797.20 \\
\$ 13,332.76\end{array}$ \\
\hline \multicolumn{4}{|c|}{ Underground - Continuous Miner Crew } \\
\hline $\begin{array}{l}\text { Miner Operator } \\
\text { Miner Helper } \\
\text { Mobile Bridge Carrier Operator } \\
\text { Roof Bolt Operator } \\
\text { Utility Person } \\
\text { Mechanic }\end{array}$ & $\begin{array}{r}6 \\
6 \\
24 \\
12 \\
6 \\
\frac{6}{60}\end{array}$ & $\begin{array}{r}\$ 79.72 \\
76.48 \\
73.48 \\
79.72 \\
71.18 \\
79.72\end{array}$ & $\begin{array}{r}\$ 478.32 \\
458.88 \\
1,763.52 \\
956.64 \\
427.08 \\
478.32 \\
\$ 4,562.76\end{array}$ \\
\hline
\end{tabular}

Underground - Shortwall Crew

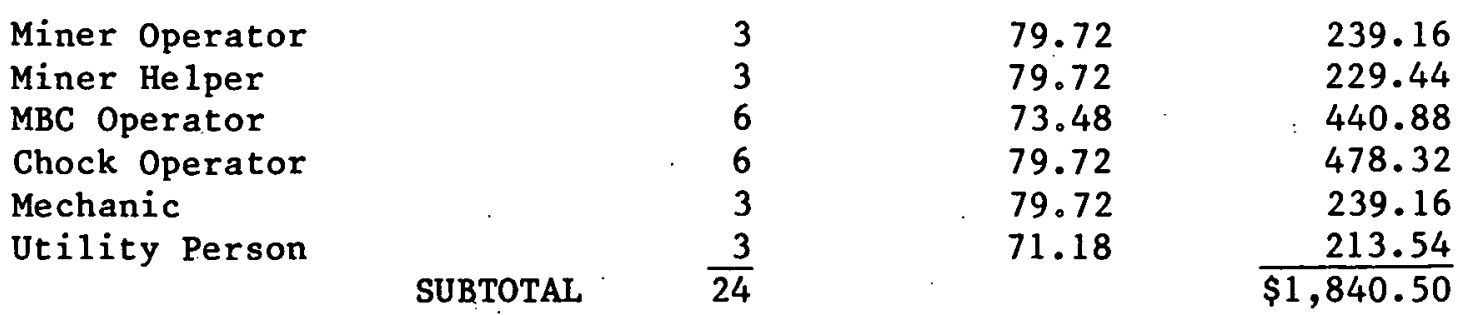




\section{SHORTWALL CASES}

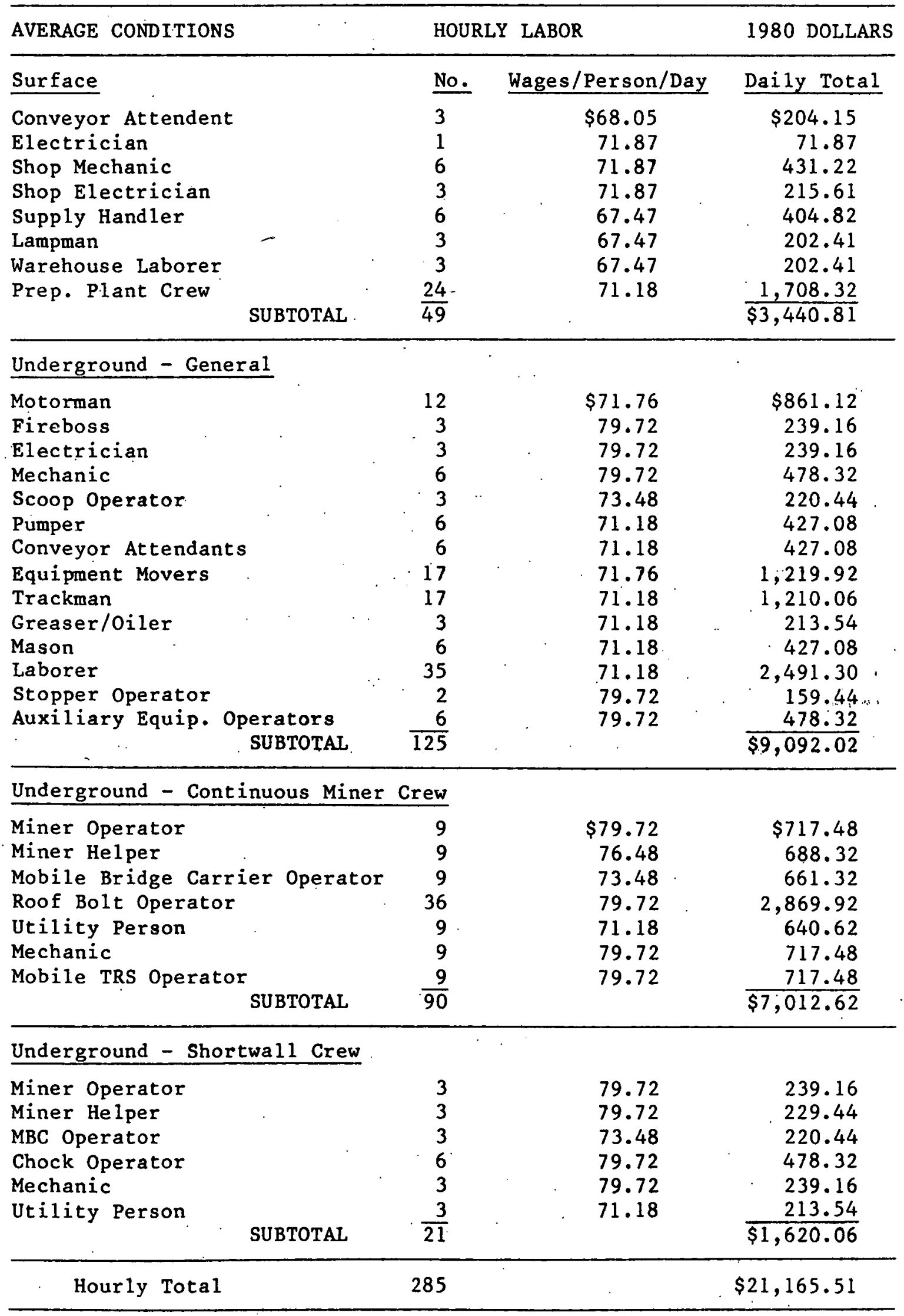




\begin{tabular}{|c|c|c|c|}
\hline \multirow{2}{*}{$\begin{array}{l}\text { IDEAL CONDITIONS } \\
\text { Surface }\end{array}$} & \multicolumn{2}{|c|}{ HOURLY LABOR } & \multirow{2}{*}{$\begin{array}{l}1980 \text { DOLLARS } \\
\text { Daily Total }\end{array}$} \\
\hline & No. & Wages/Person/Day & \\
\hline Conveyor Attendent & 3 & $\$ 68.05$ & $\$ 204.15$ \\
\hline Electrician & 1 & 71.87 & 71.87 \\
\hline Shop Mechanic & 6 & 71.87 & 431.22 \\
\hline Shop Electrician & 3 & 71.87 & 215.61 \\
\hline Supply Handler & 6 & 67.47 & 404.82 \\
\hline Lampman & 3 & 67.47 & 202.41 \\
\hline Warehouse Laborer & 3 & 67.47 & 202.41 \\
\hline Prep. Plant Crew & 24 & 71.18 & $1,708 \cdot 32$ \\
\hline SUBTOTAL & $\overline{49}$ & & $\$ 3,440.81$ \\
\hline \multicolumn{4}{|l|}{ Underground - General } \\
\hline Motorman & 12 & $\$ 71.76$ & $\$ 861.12$ \\
\hline Fireboss & 3 & 79.72 & 239.16 \\
\hline Electrician & 3 & 79.72 & 239.16 \\
\hline Mechanic & 6 & 79.72 & 478.32 \\
\hline Scoop Operator & 3 & 73.48 & 220.44 \\
\hline Pumper & 10 & 71.18 & 711.80 \\
\hline Conveyor Attendants & 6 & 71.18 & 427.08 \\
\hline Equipment Movers & 31 & 71.76 & $2,224.56$ \\
\hline Trackman & 31 & 71.18 & $2,206.58$ \\
\hline Greaser/oiler & 3 & 71.18 & 213.54 \\
\hline Mason & 10 & 71.18 & 711.80 \\
\hline Laborer & 63 & 71.18 & $4,484.34$ \\
\hline Stopper Operator & 2 & 79.72 & 159.44 \\
\hline Auxiljary Equip. Operators & 10 & 79.72 & 797.20 \\
\hline SUBTOTAI & $\overline{193}$ & & $\$ \longdiv { 1 3 , 9 7 4 . 5 4 }$ \\
\hline \multicolumn{4}{|c|}{ Underground - Continuous Miner Crew } \\
\hline Miner Operator & 6 & $\$ 79.72$ & $\$ 478.32$ \\
\hline Miner Helper & 6 & 76.48 & 458.88 \\
\hline Mobile Bridge Carrier Operator & 6 & 73.48 & 440.88 \\
\hline Roof Bolt Operator & 24 & 79.72 & 478.32 \\
\hline Utility Person & 6 & 71.18 & 427.08 \\
\hline Mechanic & 6 & 79.72 & 478.32 \\
\hline Mobile TRS Operator & 6 & 79.72 & 478.32 \\
\hline SUB'LOTAL & $\overline{60}$ & & $\overline{\$ 4,675.08}$ \\
\hline \multicolumn{4}{|l|}{ Underground - Shortwall Crew } \\
\hline Miner Operator & 3 & 79.72 & 239.16 \\
\hline Miner Helper & 3 & 79.72 & 229.44 \\
\hline$M B C$ Operator & 3 & 73.48 & 220.44 \\
\hline Chock Operator & 6 & 79.72 & 478.32 \\
\hline Mechanic & 3 & 79.72 & .. 239.16 \\
\hline Utility Person & 3 & 71.18 & 213.54 \\
\hline SUBTOTAL & $\overline{21}$ & & $\overline{\$ 1,620.06}$ \\
\hline Hourly Total & 323 & & $\$ 23,710.49$ \\
\hline
\end{tabular}


MODIFIED SHIFT PRODUCTION

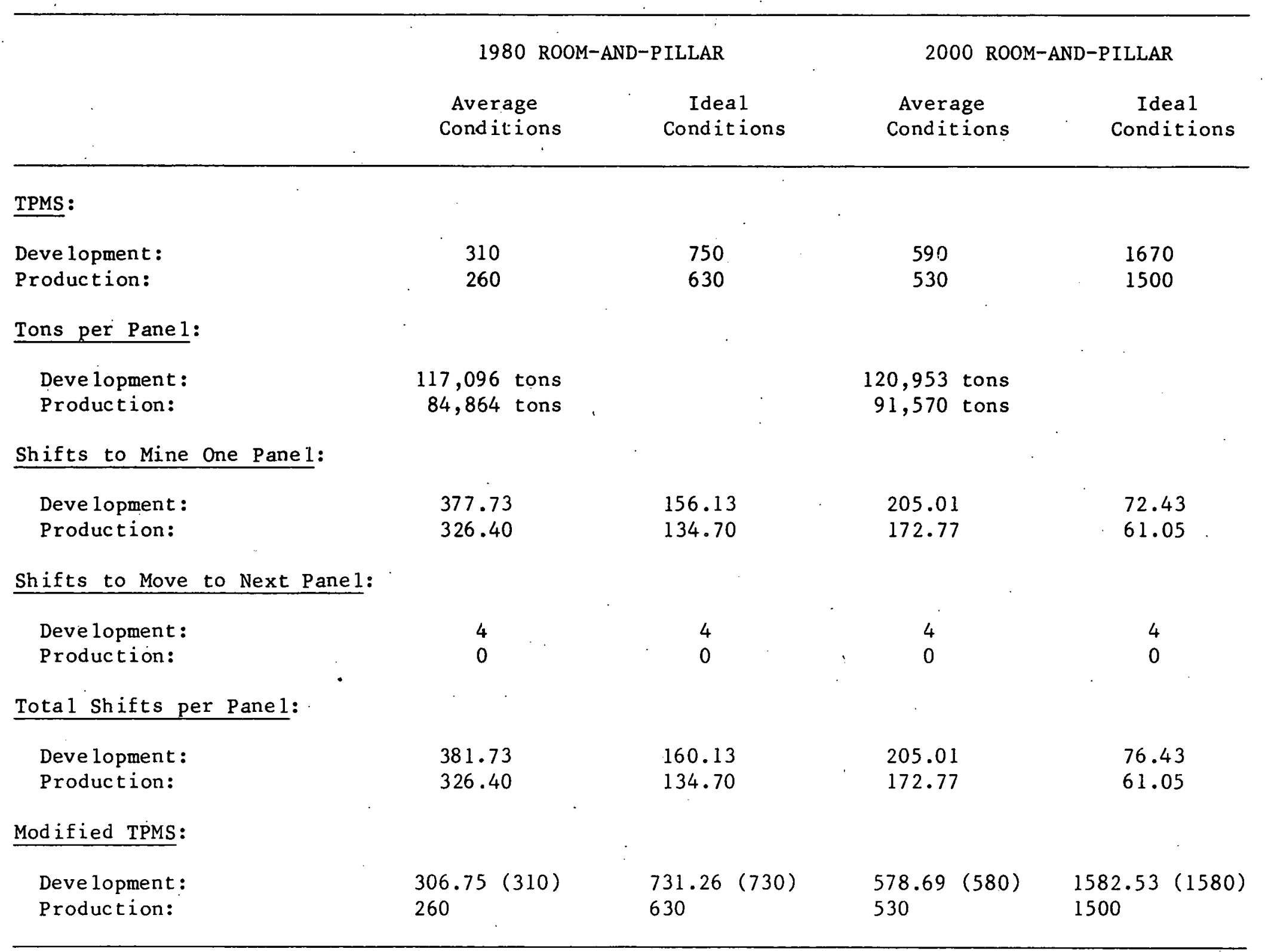




\section{DESIGN CAPACITY}

Design Capacity =

$[(N(d) \times \operatorname{TPMS}(d))+(N(P) \times \operatorname{TPMS}(P))] S \times D \times(1-R)$

$N(d)=$ Number of development units per shift

TPMS (d) = Productivity of development units

$N(P)=$ Number of productions per shift

TPMS $(P)=$ Productivity of production units

$S=$ Shifts per day

$\mathrm{D}=$ Days per week

$R=$ Reject precentage

\begin{tabular}{|c|c|c|c|c|}
\hline & \multicolumn{2}{|c|}{1980 ROOM-AND-PILLAR } & \multicolumn{2}{|c|}{2000 ROOM-AND-PILLAR } \\
\hline & $\begin{array}{l}\text { Average } \\
\text { Conditions }\end{array}$ & $\begin{array}{l}\text { Ideal } \\
\text { Conditions }\end{array}$ & $\begin{array}{l}\text { Average } \\
\text { Conditions }\end{array}$ & $\begin{array}{c}\text { Ideal } \\
\text { Conditions }\end{array}$ \\
\hline$N(d)$ & 2 & 2 & 2 & 2 \\
\hline TPMS (d) & 310 & 730 & 580 & 1580 \\
\hline$N(P)$ & 2 & 2 & 2 & 2 \\
\hline TPMS (P) & 260 & 630 & 530 & 1500 \\
\hline $\mathrm{s}$ & 3 & 3 & 3 & 3 \\
\hline $\mathrm{D}$ & 220 & 220 & 220 & 220 \\
\hline $\mathbf{R}$ & $25 \%$ & $25 \%$ & $25 \%$ & $25 \%$ \\
\hline Design & $\cdot$ & & & \\
\hline $\begin{array}{l}\text { Capacity in } \\
\text { clean tons }\end{array}$ & 575,200 & $1,346,400$ & $1,108,800$ & $3,049,200$ \\
\hline
\end{tabular}




\begin{tabular}{|c|c|c|c|}
\hline \multirow{2}{*}{$\begin{array}{l}\text { AVERAGE \& IDEAL CONDITIONS } \\
\text { Component }\end{array}$} & \multicolumn{2}{|c|}{ EQUIPMENT COST } & \multirow{2}{*}{$\begin{array}{l}1980 \text { DOLLARS } \\
\text { Total Cost }\end{array}$} \\
\hline & No. & Cost/Unit & \\
\hline Continuous Miner & 4 & $\$ 412,000$ & $\$ 1,648,000$ \\
\hline Shuttle Cars & 8 & 105,000 & 840,000 \\
\hline Roof Bolter & 4 & 76,700 & 306,800 \\
\hline Auxiliary Fan & 8 & 18,000 & 144,000 \\
\hline Scoop with Batteries \& Charger & 4 & 77,200 & 308,800 \\
\hline Bantam Duster & 4 & 18,000 & 72,000 \\
\hline Trickle Duster & 8 & 15,000 & 120,000 \\
\hline Section Power Center $\&$ Cables & 4 & 53,000 & 212,000 \\
\hline Parts Car & 4 & 10,500 & 42,000 \\
\hline Oil Storage Car & 4 & 12,000 & 48,000 \\
\hline Section Tools & 4 & 7,700 & 30,800 \\
\hline Ventilation Tubes & 4 & Lots 2,000 & 8,000 \\
\hline Section Welder & 4 & 1,700 & 6,800 \\
\hline Section Haulage Belt (42 in. $x 3000 \mathrm{ft}$ ) & 3 & $\$ 42.5 / \mathrm{ft}$ & 382,500 \\
\hline Fire Suppression & 4 & 4,200 & 16,800 \\
\hline Ratio Feeder & 4 & 79,200 & 316,800 \\
\hline & & TOTÁL & $\$ 4,503,300$ \\
\hline
\end{tabular}




\begin{tabular}{|c|c|c|c|}
\hline \multirow{2}{*}{$\begin{array}{l}\text { AVERAGE \& IDEAL CONDITIONS } \\
\text { Component }\end{array}$} & \multicolumn{2}{|c|}{ EQUIPMENT COST } & \multirow{2}{*}{$\begin{array}{l}1980 \text { DOLLARS } \\
\text { Total Cost }\end{array}$} \\
\hline & No. & Cost/Unit & \\
\hline Continuous Miner & 4 & $\$ 412,000$ & $\$ 1,648,000$ \\
\hline MBC System & 4 & 400,000 & $1,600,000$ \\
\hline Roof Bolter & 8 & 76,700 & 613,600 \\
\hline Powered Temp. Support System & 22 & 100,000 & $2,200,000$ \\
\hline Scoop with Batteries \& Charger & 4 & 77,200 & 308,800 \\
\hline Bantam Duster & 4 & 18,000 & 72,000 \\
\hline Trickle Duster & 8 & 15,000 & 120,000 \\
\hline Section Power Center \& Cables & 4 & 53,000 & 212,000 \\
\hline Parts Car & 4 & 10,500 & 42,000 \\
\hline Oil Storage Car & 4 & 12,000 & 48,000 \\
\hline Section Tools & 4 & 7,700 & 30,800 \\
\hline Ven'tilation System & 22 & 20,000 & 440,000 \\
\hline Section Welder & 4 & 1,700 & 6,800 \\
\hline Section Haulage Belt ( 42 in. $x 3000 \mathrm{ft}$ ) & 3 & $\$ 42.5 / \mathrm{ft}$ & 382,500 \\
\hline Fire Supression & 4 & 4,200 & 16,800 \\
\hline & & TOTAL & $\$ 7,741,300$ \\
\hline
\end{tabular}


1980 ROOM-AND-PILLAR CASES

\begin{tabular}{|c|c|c|c|c|c|c|c|}
\hline \multirow{2}{*}{$\begin{array}{l}\text { AVERAGE CONDITIONS } \\
\text { Component }\end{array}$} & \multirow[b]{2}{*}{ No. } & \multicolumn{3}{|c|}{ POWER COST } & \multicolumn{3}{|c|}{1980 DOLLARS } \\
\hline & & hip/Unit & Total hp & h/day & $\mathrm{kW}$ & Total kW-h & Req. \\
\hline Continuous Miner & 4 & 600 & 2400 & 9 & 1776 & 15,984 & \\
\hline Shuttle Cars & 8 & 115 & 920 & 9 & 681 & 6,129 & \\
\hline Roof Bolter & 4 & 50 & 200 & 12 & 148 & 1,776 & \\
\hline Auxiliary Fans & 8 & .15 & 120 & 18 & 89 & 1,602 & \\
\hline Mantrip Jeep & 6 & 15 & 90 & 4 & 67 & 268 & \\
\hline Mechanic Jeep & 3 & 15 & 45 & 15 & 34 & 510 & \\
\hline Personne1 Jeep & 3 & 7.5 & 22.5 & 12 & 17 & 204 & \\
\hline Supply Motor & 4 & 80 & 320 & 12 & 239 & 2,868 & \\
\hline Bantam Duster & 4 & 30 & 120 & 12 & 89 & 1,068 & \\
\hline Trickle Duster & 8 & 10 & 80 & 18 & 59 & 1,062 & \\
\hline 42-in. Conveyor & 4 & 125 & 500 & 15 & 373 & 5,595 & \\
\hline 48-in. Conveyor & 2 & 150 & 300 & 18 & 224 & 4,032 & \\
\hline Ventilation Fan & 1 & 1000 & 1000 & 24 & 746 & 17,902 & \\
\hline Outside Electricals & & & 600 & 14 & 447 & 6,258 & \\
\hline Misce 11 aneous & & & 400 & 10 & 298 & 2,980 & \\
\hline Ratio-Feeder & 4 & 100 & 400 & 9 & 296 & 2,664 & \\
\hline r & & & & & OTAL & 70,902 & \\
\hline
\end{tabular}

Power at $\$ 0.03$ per $\mathrm{kW}-\mathrm{h}$

Total Power Cost $=\frac{\$ 0.03}{\mathrm{~kW}-\mathrm{h}} \times \frac{70,902 \mathrm{~kW}-\mathrm{h}}{\text { day }} \times \frac{220 \text { days }}{\text { year }}=\frac{\$ 467,953.20}{\text { year }}$.

Power Cost per Clean Ton $=\$ 0.81$ 
1980 ROOM-AND-PILLAR CASES

\begin{tabular}{|c|c|c|c|c|c|c|}
\hline IDEAL CONDITIONS & & & NER $\cos T$ & & & 1980 DOLLARS \\
\hline Component & No. & hp/Unit & Total hp & h/day & $\mathrm{kW}$ & Total kW-h Req. \\
\hline Continuous Miner & 4 & 600 & 2400 & 12 & 1776 & 21,312 \\
\hline Shuttle Cars & 8 & 115 & 920 & 12 & 681 & 8,172 \\
\hline Roof Bolter & 4 & 50 & 200 & 14 & 148 & 2,072 \\
\hline Auxiliary Fans & 8 & 15 & 120 & 18 & 89 & 1,602 \\
\hline Ratio-Feeder & 4 & 100 & 400 & 12 & 296 & 3,552 \\
\hline Mantrip Jeep & 6 & 15 & 90 & 4 & 67 & 268 \\
\hline Mechanic Jeep & 3 & 15 & 45 & 15 & 34 & 510 \\
\hline Personnel Jeep & 3 & 7.5 & 22.5 & 12 & 17 & 204 \\
\hline Supply Motor & 4 & 80 & 320 & 12 & 239 & 2,868 \\
\hline Bantam Duster & 4 & 30 & 120 & 12 & 89 & 1,068 \\
\hline Trickle Duster & 8 & 10 & 80 & 18 & 59 & 1,062 \\
\hline 42-in. Conveyor & 4 & 125 & 500 & 15 & 373 & 5,595 \\
\hline 48-in. Conveyor & 2 & 150 & 300 & 18 & 224 & $4,0.32$ \\
\hline Ventilation Fan & 1 & 1000 & 1000 & 24 & 746 & 17,902 \\
\hline Outside Electricals & & & 600 & 14 & 447 & 6,258 \\
\hline Miscellaneous & & & 400 & 10 & 298 & 2,980 \\
\hline \multicolumn{6}{|c|}{ TOTAL } & 79,557 \\
\hline
\end{tabular}

Power at $\$ 0.03$ per $\mathrm{kW}-\mathrm{h}$

Total Power Cost $=\frac{\$ 0.03}{\mathrm{~kW}-\mathrm{h}} \times \frac{79,557 \mathrm{~kW}-\mathrm{h}}{\text { day }} \times \frac{220 \text { days }}{\text { year }}=\frac{\$ 525,076.20}{\text { year }}$

Power Cost per clean Ton $=\$ 0.39$ 
2000 ROOM-AND-PILLAR CASES

\begin{tabular}{|c|c|c|c|c|c|c|}
\hline AVERAGE CONDITIONS & & & WER COST & & & 1980 DOLLARS \\
\hline Component & No. & hp/Unit & Total hp & h/day & $\mathrm{kW}$ & Total kW-h Req. \\
\hline Continuous Miner & 4 & 600 & 2400 & 9 & 1776 & 15,984 \\
\hline MBC Unit & 4 & 120 & 480 & 9 & 358 & 3,222 \\
\hline Roof Bolter & 8 & 50 & 400 & 6 & 298 & 1,788 \\
\hline $\begin{array}{l}\text { Powered Temp. } \\
\text { Supports }\end{array}$ & 22 & 40 & 880 & 2 & 656 & 1,312 \\
\hline Ventilation System & 22 & 15 & 330 & 18 & 246 & $4 ; 428$ \\
\hline Mantrip Jeep & 6 & 15 & 90 & 4 & 67 & 268 \\
\hline Mechanic Jeep & 3 & 15 & 45 & 15 & 34 & 510 \\
\hline Personnel Jeep & 3 & 7.5 & 22.5 & 12 & 17 & 204 \\
\hline Supply Motor & 4 & 80 & 320 & 12 & 239 & 2,868 \\
\hline Bantam Duster & 4 & 30 & 120 & 12 & 89 & 1,068 \\
\hline Trickle Duster & 8 & 10 & 80 & 18 & 59 & 1,062 \\
\hline 42-in. Conveyor & 4 & 125 & 500 & 15 & 373 & 5,595 \\
\hline 48-in. Conveyor & 2 & 150 & 300 & 18 & 224 & 4,032 \\
\hline Ventilation Fan & 1 & 1000 & 1000 & 24 & 746 & 17,902 \\
\hline Outside Electricals & & & 600 & 14 & 447 & 6,258 \\
\hline Miscellaneous & & & 400 & 10 & 298 & 2,980 \\
\hline \multicolumn{6}{|r|}{ TOTAL } & 69,481 \\
\hline
\end{tabular}

Power at $\$ 0.03$ per $k W-h$

Total Power Cost $=\frac{\$ 0.03}{\mathrm{~kW}-\mathrm{h}} \times \frac{69,481 \mathrm{~kW}-\mathrm{h}}{\text { day }} \times \frac{220 \text { days }}{\text { year }}=\frac{\$ 458,574.60}{\text { year }}$

Power Cost per clean Ton $=\$ 0.41$ 
2000 ROOM-AND-PILLAR CASES

\begin{tabular}{lrrrrrr}
\hline IDEAL CONDITIONS & \multicolumn{2}{c}{ POWER COST } & & & 1980 DOLLARS \\
Component & No. hp/Unit & Total hp & h/day & kW & Total kW-h Req. \\
& & & & & & \\
\hline
\end{tabular}

Power at $\$ 0.03$ per $\mathrm{kW}-\mathrm{h}$

Total Power Cost $=\frac{\$ 0.03}{\mathrm{~kW}-\mathrm{h}} \times \frac{75,883 \mathrm{~kW}-\mathrm{h}}{\text { day }} \times \frac{220 \text { days }}{\text { year }}=\frac{\$ 500,827.80}{\text { year }}$

Power Cost per Clean Ton $=\$ 0.16$ 
SALARIED PERSONNEL REQUIREMENTS AND COSTS

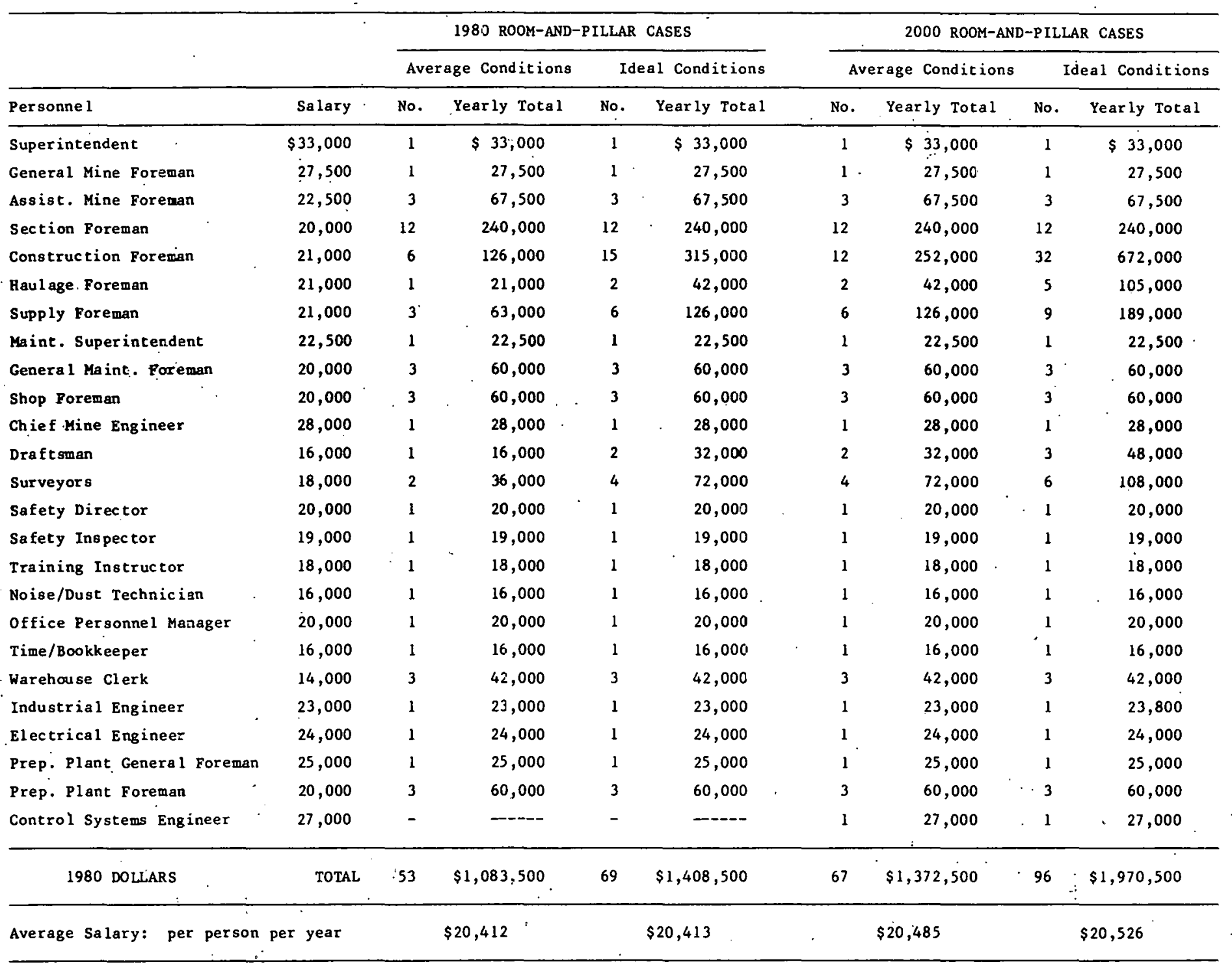




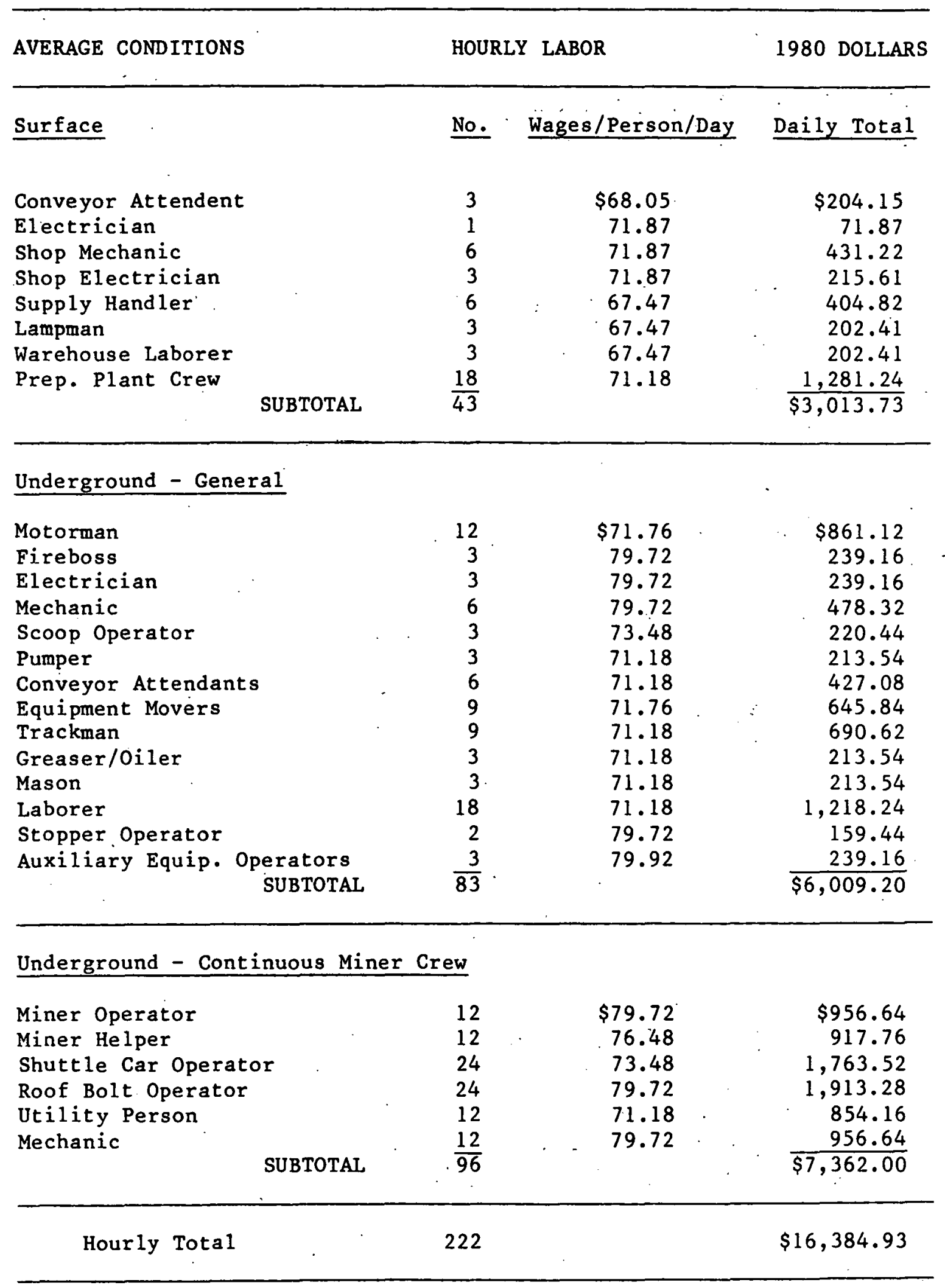




\begin{tabular}{|c|c|c|c|}
\hline IDEAL CONDITIONS & \multicolumn{2}{|c|}{ HOURLY LABOR } & 1980 DOLLARS \\
\hline Surface & No. & Wages/Person/Day & Daily Total \\
\hline $\begin{array}{l}\text { Conveyor Attendent } \\
\text { Electrician } \\
\text { Shop Mechanic } \\
\text { Shop Electrician } \\
\text { Supply Handler } \\
\text { Lampman } \\
\text { Warehouse Laborer } \\
\text { Prep. Plant Crew }\end{array}$ & $\begin{array}{r}3 \\
1 \\
6 \\
3 \\
6 \\
3 \\
3 \\
\frac{24}{49}\end{array}$ & $\begin{array}{r}\$ 68.05 \\
71.87 \\
71.87 \\
71.87 \\
67.47 \\
67.47 \\
67.47 \\
71.18\end{array}$ & $\begin{array}{r}\$ 204.15 \\
71.87 \\
431.22 \\
215.61 \\
404.82 \\
202.41 \\
202.41 \\
1,708.32 \\
\$ 3,440.81\end{array}$ \\
\hline Underground - General & & & \\
\hline $\begin{array}{l}\text { Motorman } \\
\text { Fireboss } \\
\text { Electrician } \\
\text { Mechanic } \\
\text { Scoop Operator } \\
\text { Pumper } \\
\text { Conveyor Attendants } \\
\text { Equipment Movers } \\
\text { Trackman } \\
\text { Greaser/Oiler } \\
\text { Mason } \\
\text { Laborer } \\
\text { Stopper Operator } \\
\text { Auxiliary Equip. Operators } \\
\quad \text { SUBTOTAL }\end{array}$ & $\begin{array}{r}12 \\
3 \\
3 \\
6 \\
3 \\
3 \\
6 \\
21 \\
21 \\
3 \\
7 \\
42 \\
2 \\
7 \\
143\end{array}$ & $\begin{array}{r}\$ 71.76 \\
79.72 \\
79.72 \\
79.72 \\
73.48 \\
71.18 \\
71.18 \\
71.76 \\
71.18 \\
71.18 \\
71.18 \\
71.18 \\
79.72 \\
79.72\end{array}$ & $\begin{array}{r}\$ 861.12 \\
239.16 \\
239.16 \\
478.32 \\
220.44 \\
498.26 \\
427.08 \\
1,506.96 \\
1,494.78 \\
213.54 \\
498.26 \\
2,989.56 \\
159.44 \\
558.04 \\
\$ 10,384.12\end{array}$ \\
\hline
\end{tabular}

Underground - Continuous Miner Crew

\begin{tabular}{llrr} 
Miner Operator & 12 & $\$ 79.72$ & $\$ 956.64$ \\
Miner Helper & 12 & 76.48 & 917.76 \\
Shuttle Car Operator & 24 & 73.48 & $1,763.52$ \\
Roof Bolt Operator & 24 & 79.72 & $1,913.28$ \\
Utility Person & 12 & 71.18 & 854.16 \\
Mechanic & 12 & 79.72 & 956.64 \\
\multicolumn{1}{c}{ SUBTOTAL } & $\frac{12}{96}$ & & $\$ 7.362 .00$
\end{tabular}




\begin{tabular}{|c|c|c|c|}
\hline AVERAGE CONDITIONS & \multicolumn{2}{|c|}{ HOURLY LABOR } & 1980 DOLLARS \\
\hline Surface & №. & Wages/Person/Day & Daily Total \\
\hline $\begin{array}{l}\text { Conveyor Attendent } \\
\text { Electrician } \\
\text { Shop Mechanic } \\
\text { Shop Electrician } \\
\text { Supply Handler } \\
\text { Lampman } \\
\text { Warehouse Laborer } \\
\text { Prep. Plant Crew }\end{array}$ & $\begin{array}{r}3 \\
1 \\
6 \\
3 \\
6 \\
3 \\
3 \\
24 \\
49\end{array}$ & $\begin{array}{r}\$ 68.05 \\
71.87 \\
71.87 \\
71.87 \\
67.47 \\
67.47 \\
67.47 \\
71.18\end{array}$ & $\begin{array}{r}\$ 204.15 \\
71.87 \\
431.22 \\
215.61 \\
404.82 \\
202.41 \\
202.41 \\
1,708.32 \\
\$ 3,440.81\end{array}$ \\
\hline \multicolumn{4}{|l|}{ Underground - General } \\
\hline $\begin{array}{l}\text { Motorman } \\
\text { Fireboss } \\
\text { Electrician } \\
\text { Mechanic } \\
\text { Scoop Operator } \\
\text { Pumper } \\
\text { Conveyor Attendants } \\
\text { Equipment Movers } \\
\text { Trackman } \\
\text { Greaser/Oiler } \\
\text { Mason } \\
\text { Laborer } \\
\text { Stopper Operator } \\
\text { Auxiliary Equip. Operators } \\
\end{array}$ & $\begin{array}{r}12 \\
3 \\
3 \\
6 \\
3 \\
3 \\
6 \\
17 \\
17 \\
3 \\
6 \\
35 \\
2 \\
6 \\
125 \\
\end{array}$ & $\begin{array}{r}\$ 71.76 \\
79.72 \\
79.72 \\
79.72 \\
73.48 \\
71.18 \\
71.18 \\
71.76 \\
71.18 \\
71.18 \\
71.18 \\
71.18 \\
79.72 \\
79.72\end{array}$ & $\begin{array}{r}\$ 861.12 \\
239.16 \\
239.16 \\
478.32 \\
220.44 \\
427.08 \\
427.08 \\
1,219.92 \\
1,210.06 \\
213.54 \\
427.08 \\
2,491.30 \\
159.44 \\
478.32 \\
\$ 9,092.02\end{array}$ \\
\hline \multicolumn{4}{|c|}{ Underground - Continuous Miner Crew } \\
\hline $\begin{array}{l}\text { Miner Operator } \\
\text { Miner Helper } \\
\text { Shuttle Car Operator } \\
\text { Roof Bolt Operator } \\
\text { Utility Person } \\
\text { Mechanic } \\
\end{array}$ & $\begin{array}{l}12 \\
12 \\
12 \\
24 \\
12 \\
\frac{12}{96}\end{array}$ & $\begin{array}{r}\$ 79.72 \\
76.48 \\
73.48 \\
79.72 \\
79.72 \\
79.72\end{array}$ & $\begin{array}{r}\$ 956.64 \\
917.76 \\
881.76 \\
1,913.28 \\
956.64 \\
956.64 \\
\$ 7,436.88\end{array}$ \\
\hline Hourly Total & 270 & & $\$ 19,969.71$ \\
\hline
\end{tabular}




\begin{tabular}{|c|c|c|c|}
\hline IDEAL CONDITIONS & \multicolumn{2}{|c|}{ HOURLY LABOR } & 1980 DOLLARS \\
\hline Surface & No. & Wages/Person/Day & Daily Total \\
\hline $\begin{array}{l}\text { Hoistman } \\
\text { Electrician } \\
\text { Shop Mechanic } \\
\text { Shop Electrician } \\
\text { Supply Handler } \\
\text { Lampman } \\
\text { Warehouse Laborer } \\
\text { Prep. Plant Crew }\end{array}$ & $\begin{array}{r}3 \\
1 \\
6 \\
3 \\
6 \\
3 \\
3 \\
\frac{30}{55}\end{array}$ & $\begin{array}{r}\$ 68.05 \\
71.87 \\
71.87 \\
71.87 \\
67.47 \\
67.47 \\
67.47 \\
71.18\end{array}$ & $\begin{array}{r}\$ 204.15 \\
71.87 \\
431.22 \\
215.61 \\
404.82 \\
202.41 \\
202.41 \\
2,135.40 \\
\$ 3,867.89\end{array}$ \\
\hline Underground - General & & & ) \\
\hline $\begin{array}{l}\text { Motorman } \\
\text { Fireboss } \\
\text { Electrician } \\
\text { Mechanic } \\
\text { Scoop Operator } \\
\text { Pumper } \\
\text { Conveyor Attendants } \\
\text { Equipment Movers } \\
\text { Trackman } \\
\text { Greaser/Oiler } \\
\text { Mason } \\
\text { Laborer } \\
\text { Stopper Operator } \\
\text { Auxiliary Equip. Operators } \\
\quad \text { SUBTOTAL }\end{array}$ & $\begin{array}{r}12 \\
3 \\
3 \\
6 \\
3 \\
16 \\
6 \\
48 \\
48 \\
3 \\
16 \\
95 \\
2 \\
16 \\
277\end{array}$ & $\begin{array}{r}\$ 71.76 \\
79.72 \\
79.72 \\
79.72 \\
73.48 \\
71.18 \\
71.18 \\
71.76 \\
71.18 \\
71.18 \\
71.18 \\
71.18 \\
79.72 \\
79.72\end{array}$ & $\begin{array}{r}\$ 861.12 \\
239.16 \\
239.16 \\
478.32 \\
220.44 \\
1,138.88 \\
427.08 \\
3,444.48 \\
3,416.64 \\
213.54 \\
1,138.88 \\
6,762.10 \\
159.44 \\
1,257.52 \\
\$ 19,801.22\end{array}$ \\
\hline Underground - Continuous Miner & Crew & & \\
\hline $\begin{array}{l}\text { Miner Operator } \\
\text { Miner Helper } \\
\text { Shuttle Car Operator } \\
\text { Roof Bolt Operator } \\
\text { Utility Person } \\
\text { Mechanic } \\
\text { Mobile TRS Operator SUBT̄OTAL }\end{array}$ & $\begin{array}{l}12 \\
12 \\
12 \\
24 \\
12 \\
12 \\
96\end{array}$ & $\begin{array}{r}\$ 79.72 \\
76.48 \\
73.48 \\
79.72 \\
79.72 \\
79.72\end{array}$ & $\begin{array}{r}\$ 956.64 \\
917.76 \\
881.76 \\
1,913.28 \\
956.64 \\
956.64 \\
\$ 7,436.88\end{array}$ \\
\hline Hourly Total & 428 & & $\$ 31,105.99$ \\
\hline
\end{tabular}




\section{APPENDIX D}

\section{COST UPDATE FACTORS}

This information was provided by $M$. Dean Westerfield, and originally appeared in I.O.M. 311.2-969 of June 9, 1980. 
The following cost update factors were used as input, or to modify input to the costing analysis of baseline mining technologies.

Equipment Cost, General

Production Section Equip.

.6757

5.2432

$--$

Power Cost/Clean Ton

Preparation Plant

$-$

--

2.7258

Salaries

General Inflation (GNP Deflator)

.2753

$-$

1.5899

1.0345

--

3.9299

2.8849

Manpower Costs

$1975-1980$

1975-2000

$\begin{array}{cccc}\text { Average } & \text { Ideal } & \text { Average } & \text { Ideal } \\ \text { Conditions } & \text { Conditions } & \text { Conditions } & \text { Conditions }\end{array}$

Shortwall

Cont inuous

.3414

.3420

I.ongwall

.3576

.3356
.3420
.3542

5.6778

5.6482

5.6329

5.6733

5.6482

5.6311

The cost update factor is defined such that

$$
\text { Base year cost } x(1+\text { cost update })=\text { Future Cost }
$$

All of the update factors with the exception of the manpower cost update and general inflation factors were derived from data generated by $M$. Gyamfi (IOM $311.3-104,10 / 16 / 78$ ). This data is reproduced in Table D-1.

The manpower cost update was found as follows

1975 to 1980 :

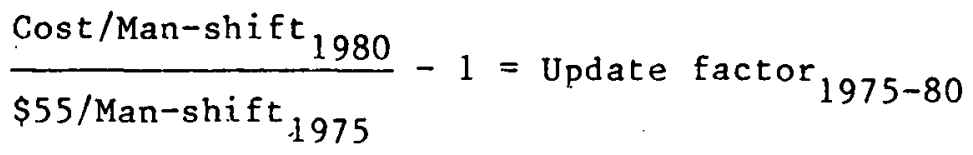

1975 to 2000 :

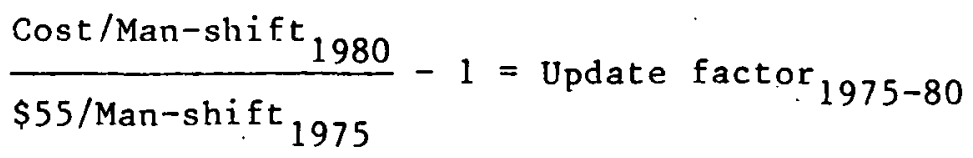


The 4.92989 was derived from M. Gyamfi's manpower cost data. The $\$ 55.00$ base year cost was necessitated by the internal programming of the N!IS model. Manpower cost update factors were different in each sazt because of the different mixes of labor employed in each mining scenario.

The general price deflator was derived from Data Resources Inc. data (DRI Energy Review, Autumn 1979, pg. 106). DRI projected the inflation rates for the years indicated in the table below. Using 1 inear interpolation for each year not included in the data below, the inflation rate for each year from 1980 to 2000 was projected. The product of these numbers was used as the general price deflator for 1980 to 2000.

The general price deflator was used to project the cost of royalties to the year 2000 and deflate year 2000 coal costs to 1980 levels.

ANNUAL RATE OF CHANGE IN GNP DEFLATOR

$$
1980
$$

1981

1982

1985

1990

1995

$8.7 \%$

8.7

8.2

7.4

6.4

5.8

5.3

Source: DRI Energy Review, Autumn 1979 
Table D-1. Projected Price Indexes

\begin{tabular}{|c|c|c|c|c|}
\hline Year & $\begin{array}{l}\text { Chemical Plant } \\
\text { and Equipment } \\
\text { Price Index }\end{array}$ & $\begin{array}{c}\text { Mining } \\
\text { Equipment } \\
\text { Price Index }\end{array}$ & $\begin{array}{c}\text { Electric } \\
\text { Power } \\
\text { Price Index }\end{array}$ & $\begin{array}{c}\text { Coal Miners } \\
\text { Daily Wages } \\
\text { (Current Dollars) } \\
\$ / \text { Day }\end{array}$ \\
\hline & & & & . \\
\hline 1975 & 178 & 185 & 195 & 60.00 \\
\hline 1976 & & & 205 & \\
\hline 1977 & & & & 67.68 \\
\hline 1978 & 212 & 246 & 226 & 75.52 \\
\hline 1979 & & & . & 83.84 \\
\hline 1980 & 227 & 310 & 232 & 91.44 \\
\hline 1981 & & & & 101.68 \\
\hline 1982 & 258 & 364 & & 110.40 \\
\hline 1983 & & & & 119.60 \\
\hline 1984 & 294 & 428 & & 132.24 \\
\hline 1985 & 314 & 464 & 268 & 143.52 \\
\hline 1986 & 323 & 505 & & 154.56 \\
\hline 1987 & & & & 170.40 \\
\hline 1988 & 341 & 599 & & 184.72 \\
\hline 1989 & & & & 192.32 \\
\hline 1990 & 360 & 700 & 319 & 218.72 \\
\hline \multicolumn{5}{|l|}{1991} \\
\hline 1992 & 378 & 800 & 345 & 252.76 \\
\hline \multicolumn{5}{|l|}{1993} \\
\hline 1994 & 397 & 900 & & 292.09 \\
\hline 1995 & 407 & 950 & 388 & 314.00 \\
\hline 1996 & 417 & 1000 & & 337.55 \\
\hline \multicolumn{5}{|l|}{1997} \\
\hline 1998 & 439 & 1090 & 436 & 390.08 \\
\hline \multicolumn{5}{|l|}{1999} \\
\hline 2000 & 461 & 1155 & 472 & 450.79 \\
\hline
\end{tabular}

Source: M. Gyamfi IOM $311.3-104,10 / 16 / 78$ 
APPENDIX E

COST ANALYSIS RESULTS

The purpose of Appendix E, Cost Analys is

Results is to document the results of the cost analysis performed by the NUS coal

costing model for the twelve study cases. 


\begin{tabular}{|c|c|c|c|c|c|}
\hline & \multirow[b]{2}{*}{ Output } & \multicolumn{2}{|c|}{1980 Systems } & \multicolumn{2}{|c|}{2000 Systems } \\
\hline & & $\begin{array}{l}\text { Average } \\
\text { Conditions } \\
\text { (costs in }\end{array}$ & $\begin{array}{c}\text { Ideal } \\
\text { Conditions } \\
1980 \text { dollars) }\end{array}$ & $\begin{array}{l}\text { Average } \\
\text { Conditions } \\
\text { (costs in }\end{array}$ & $\begin{array}{c}\text { Ideal } \\
\text { Conditions } \\
2000 \text { dollars) }\end{array}$ \\
\hline \multirow[t]{9}{*}{ I. } & Production sizing & & & & \\
\hline & Reject percentage & 21.0 & 21.0 & 21.0 & 21.0 \\
\hline & Design capacity - raw tons & $1,438,800$ & $2,923,800$ & $1,848,000$ & $3,504,600$ \\
\hline & Tons per machnie shift & & & & \\
\hline & Room-and-Pillar & 450 & 1330 & 530 & 1390 \\
\hline & Longwall unit & 830 & 1770 & 1210 & 2530 \\
\hline & Shortwall unit & - & - & - & - \\
\hline & Machine sections per shift & 4 & 3 & 4 & 3 \\
\hline & Design capacity - clean tons & $1,136,652$ & $2,309,802$ & $1,459,920$ & $2,768,634$ \\
\hline \multirow[t]{8}{*}{ II. } & Manpower & & & & \\
\hline & Hourly Labor & & & & \\
\hline & Daily requirement (persons) & 293 & 353 & 318 & 392 \\
\hline & $\begin{array}{l}\text { Direct cost per year } \\
\text { Total cost per year }\end{array}$ & $\begin{array}{l}4,793,245 \\
9,375,791\end{array}$ & $\begin{array}{r}5,716,537 \\
12,895,924\end{array}$ & $\begin{array}{l}25,546,390 \\
48,527,450\end{array}$ & $\begin{array}{l}31,117,004 \\
64,067,640\end{array}$ \\
\hline & $\begin{array}{l}\text { Cost per ton } \\
\text { Salaried }\end{array}$ & 8.25 & 5.62 & 33.24 & 23.14 \\
\hline & Daily requirement (persons) & 66 & 83 & 70 & 89 \\
\hline & Direct cost per year & $1,820,511$ & $2,269,221$ & $7,081,790$ & $9,009,702$ \\
\hline & $\begin{array}{l}\text { Total cost per year } \\
\text { Cost per ton }\end{array}$ & $\begin{array}{c}2,548,716 \\
2.24\end{array}$ & $\begin{array}{c}3,176,910 \\
1.38\end{array}$ & $\begin{array}{c}9,914,506 \\
6.79\end{array}$ & $\begin{array}{c}12,613,583 \\
4.56\end{array}$ \\
\hline \multirow[t]{5}{*}{ III. } & $\begin{array}{l}\text { Equipment and Construction } \\
\text { Section equipment costs }\end{array}$ & $\therefore$ & & & \\
\hline & Continuous R\&P units & $\begin{array}{l}3,171,000 \\
5,410,800\end{array}$ & $\begin{array}{l}2,213,900 \\
5,410,800\end{array}$ & $19,471,403$ & $\begin{array}{l}13,707,581 \\
25,801,930\end{array}$ \\
\hline & Shortwall units & ${ }^{2,410,000}$ & - & 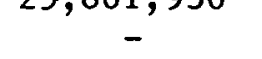 & - \\
\hline & Belt haulage system cost & $3,172,062$ & $2,696,169$ & $11,818,377$ & $10,045,309$ \\
\hline & Track haulage system cost & - & - & - & - \\
\hline
\end{tabular}


1980 Systems

Output

$\begin{array}{cc}\begin{array}{c}\text { Average } \\ \text { Conditions }\end{array} & \text { Ideal } \\ \text { (costs in } 1980 \text { dollars) }\end{array}$

(costs in 1980 dollars)
2000 Systems

$\begin{array}{cc}\text { Average } & \text { Ideal } \\ \text { Conditions } & \text { Conditions }\end{array}$

(costs in 2000 dollars)
Underground auxiliary equip. costs

$$
\begin{aligned}
& \text { Dewatering } \\
& \text { Fire and safety } \\
& \text { Communications }
\end{aligned}
$$

Surface auxiliary equip. costs

Heavy equip.

Personnel vehicles

Ventilation

Miscellaneous

Site prep. \& const. costs Mine entries

Other surface const.

Exploration costs

Abandonment costs

Reserve deposit size (tons)

323,406

149,136

251,352

$1,808,059$

36,865

268,109

268,109

127,528

$8,330,294$

106,000

127,528

$37,863,157$

$$
8,767,843
$$$$
7.71
$$

Annual cost

Cost per ton

v. Power

Annual cost

Cost per ton

VI. Preproduction Development

Direct and indirect costs

Development time (years)

Coal production for period

(tons)

$\begin{array}{cc}443,294 & 435,890 \\ 0.39 & 0.19\end{array}$

0.39

$20,075,497$

1.21

$10,845,340$

.44

428,478

395,658
$1,204,938$

555,645

936,480

$6,736,413$

137,350

998,912

998,912

258,990

$20,986,519$

276,500

258,900

$48,631,578$

$9,860,553$
4.30

4.30

24.36

950,408

0.65

$82,281,809$
1.03

429,057

374,408
$49,881,255$

.45

593,104

543,158

936,480

$6,736,413$

137,350

749,184

998,912

258,990

$37,471,302$

524,400

258,900

$92,226,314$

15.56

902,575

0.33 


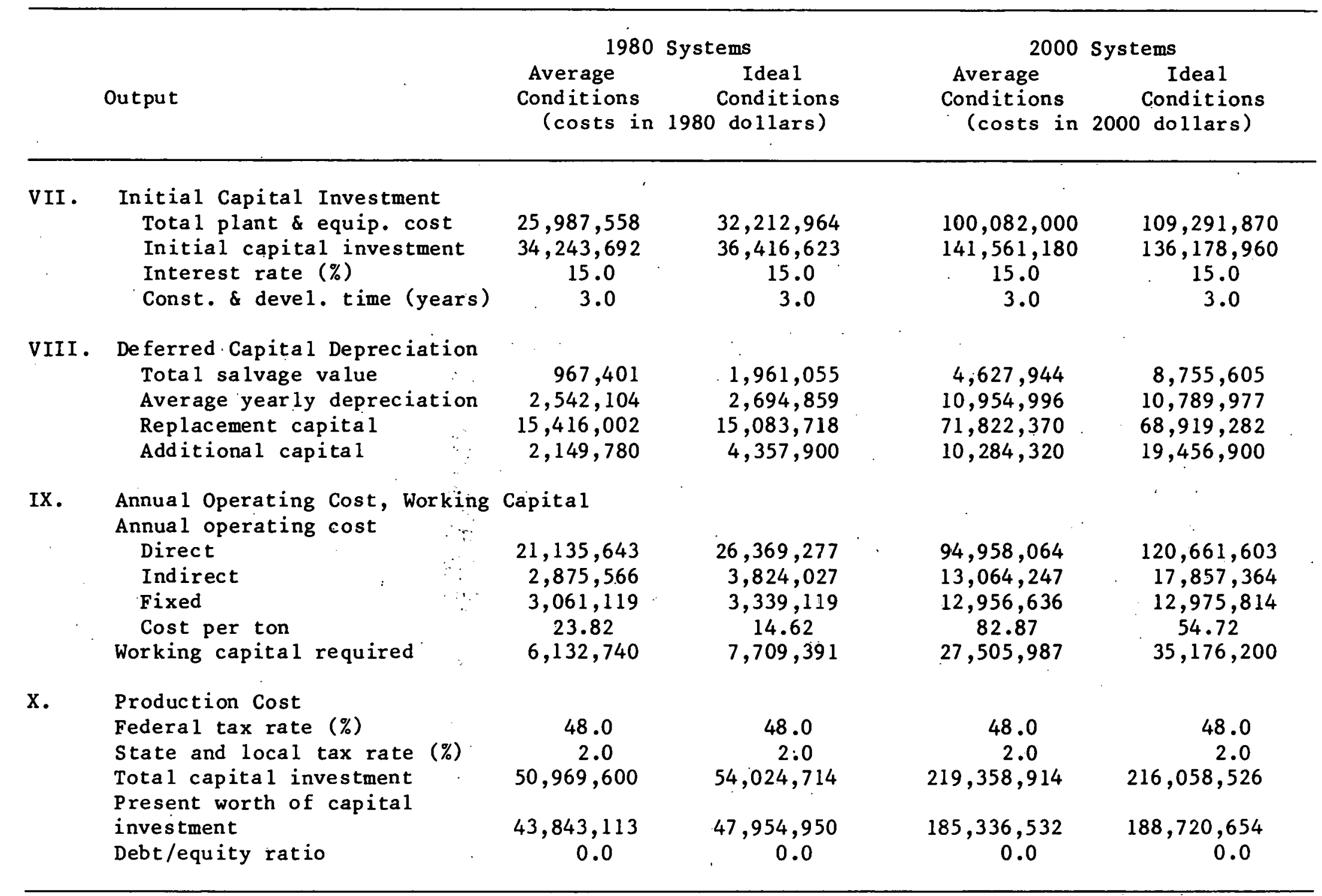


LONGWALL CASES (Continuation 3)

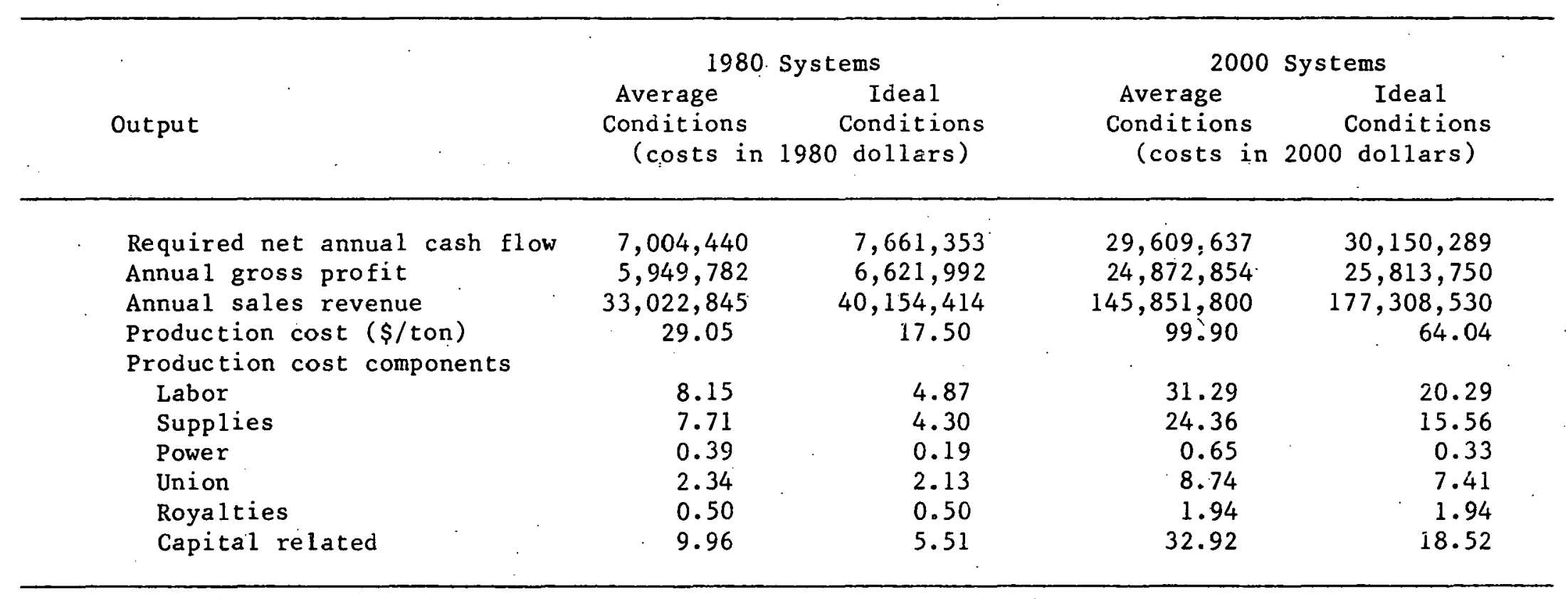


SHORTWALL CASES

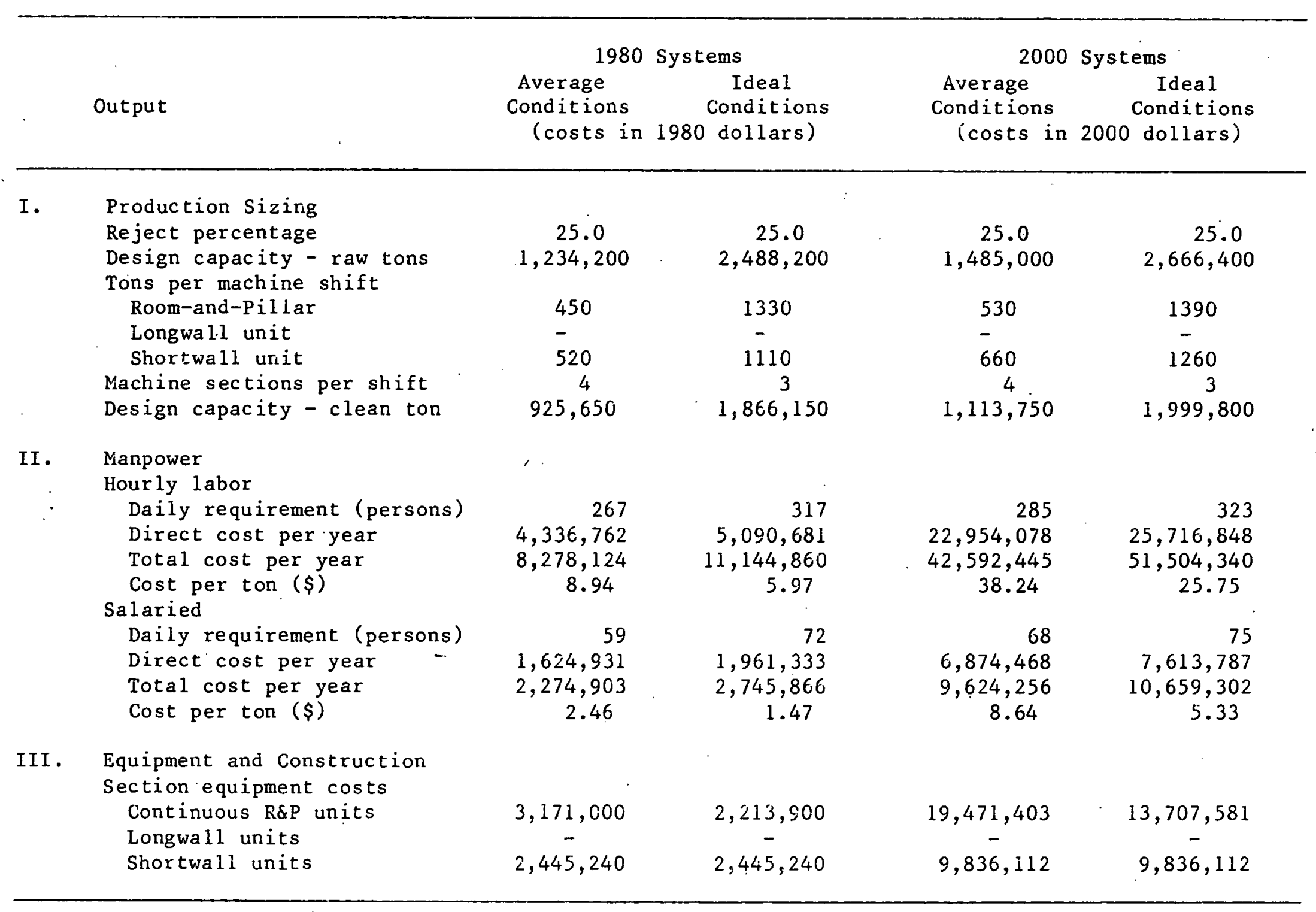




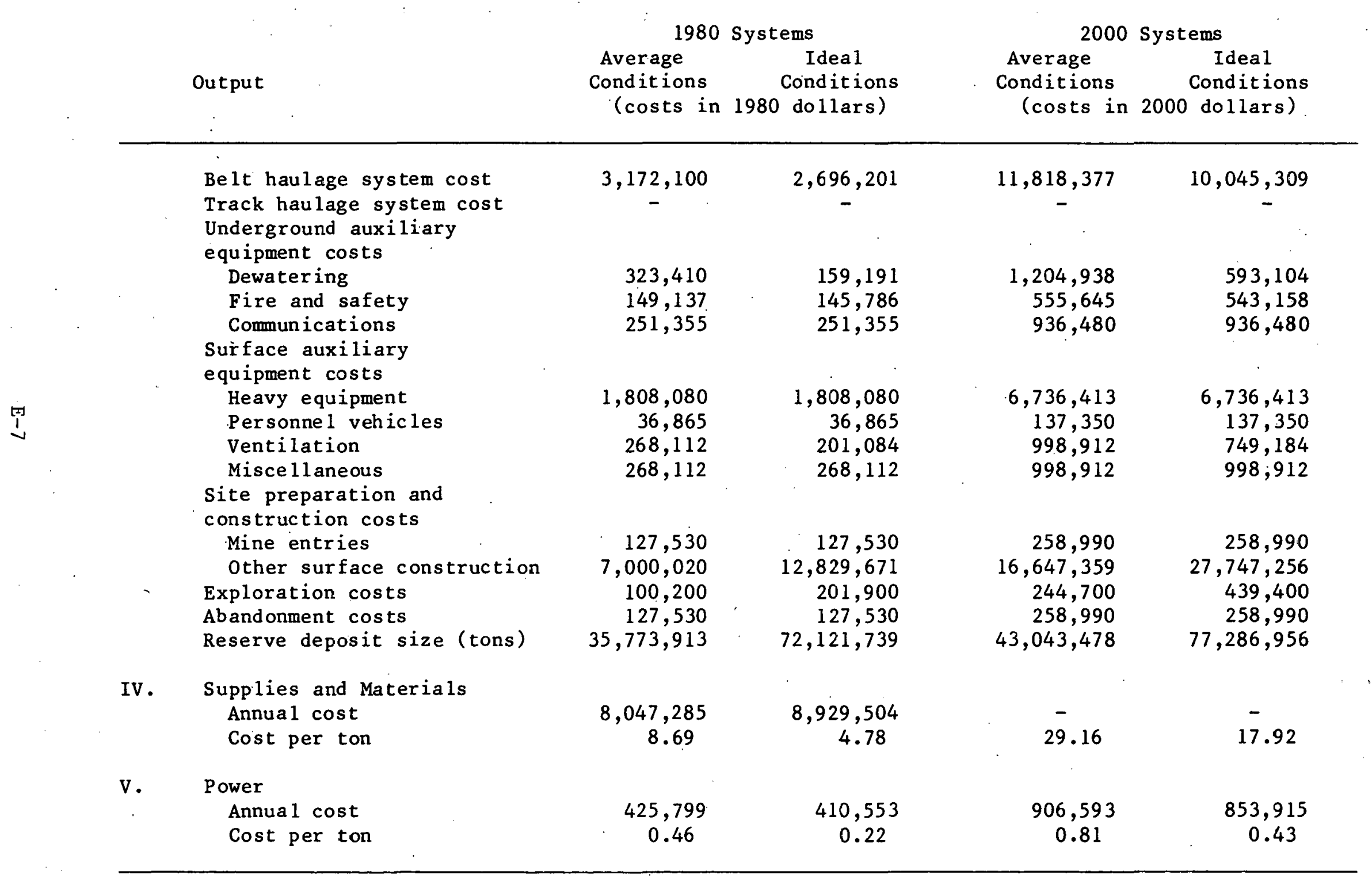


SHORTWALL CASES (Continuation 2)

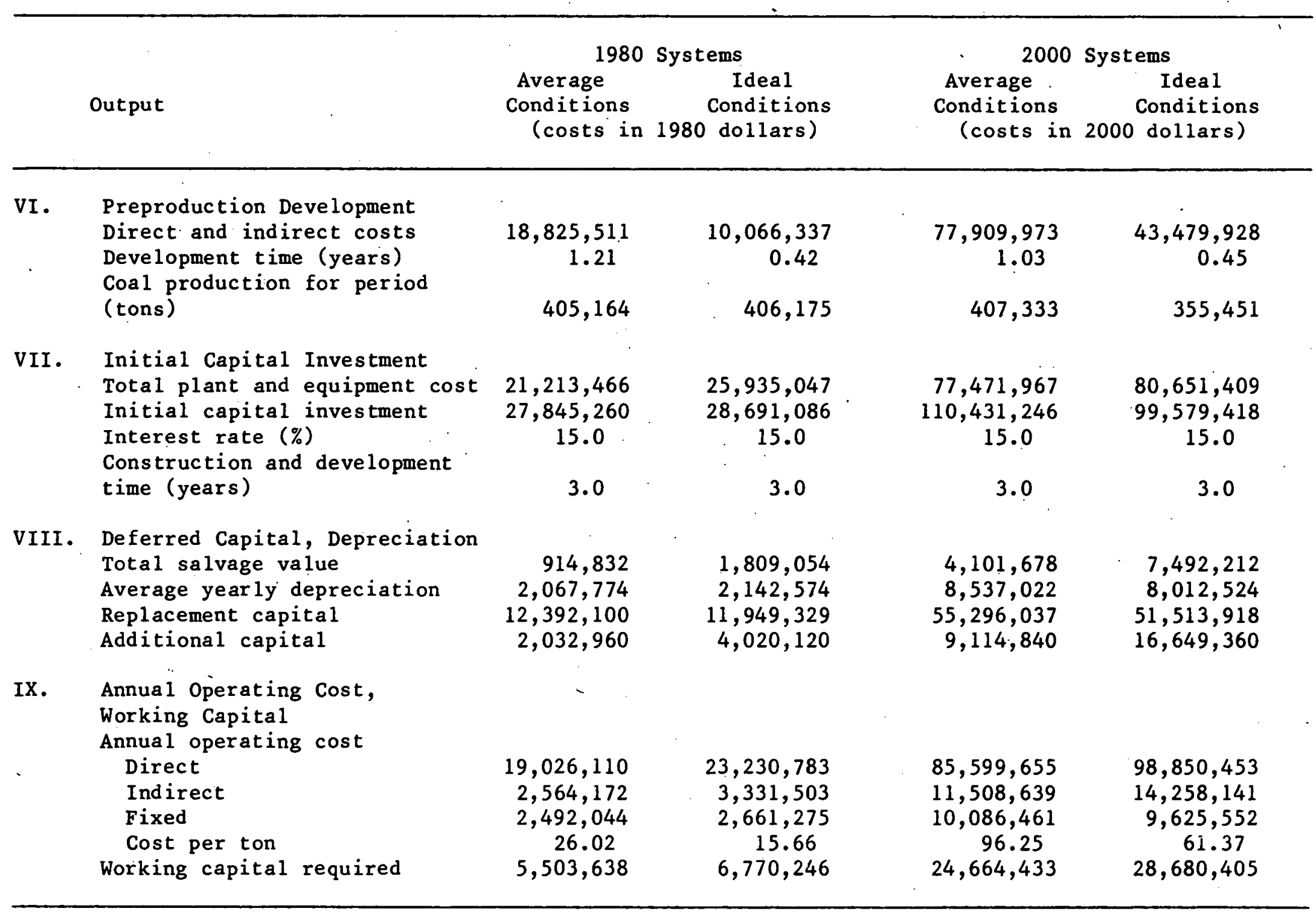


SHORTWALL CASES (Continuation 3)

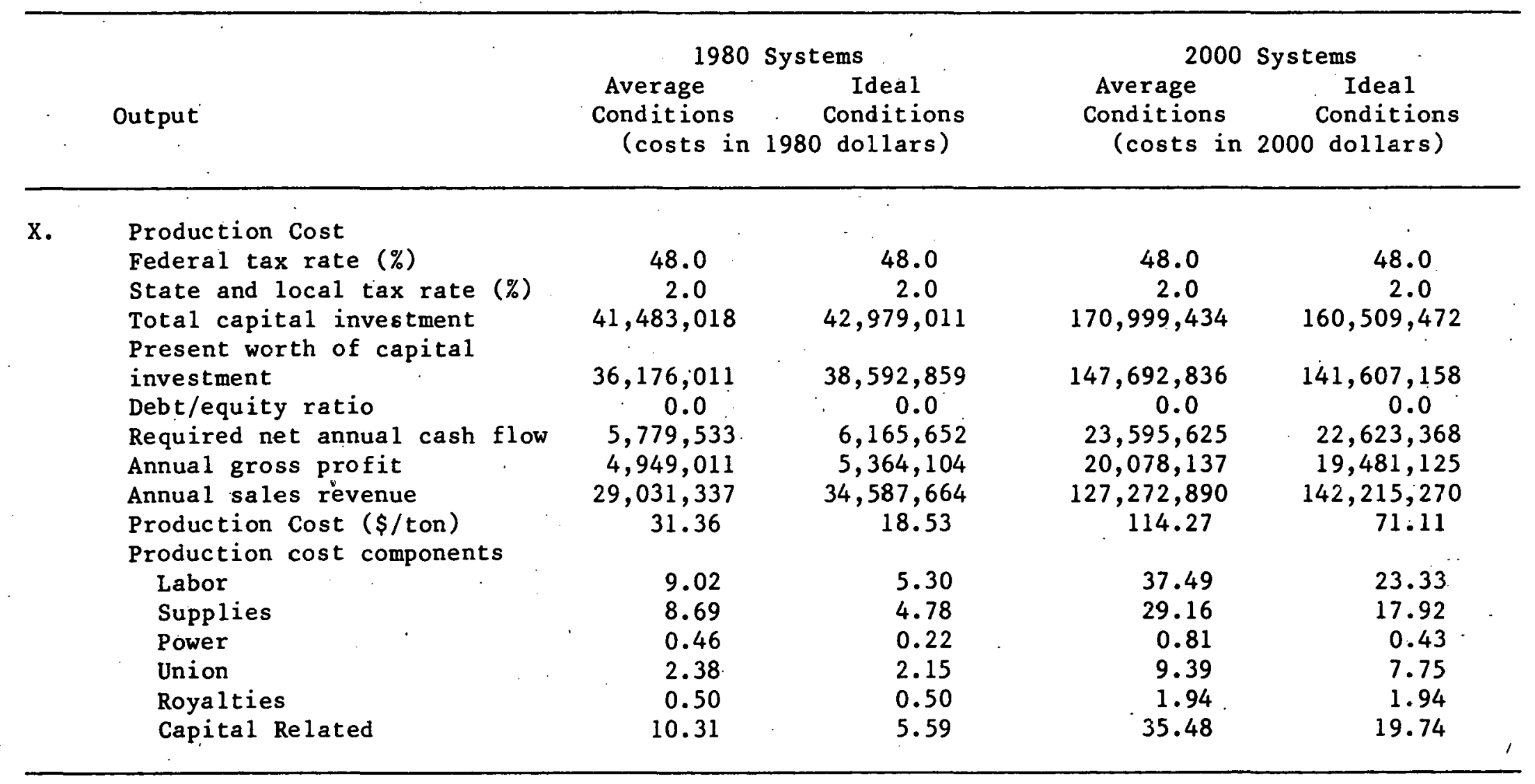


CONTINUOUS ROOM-AND-PILLAR CASES

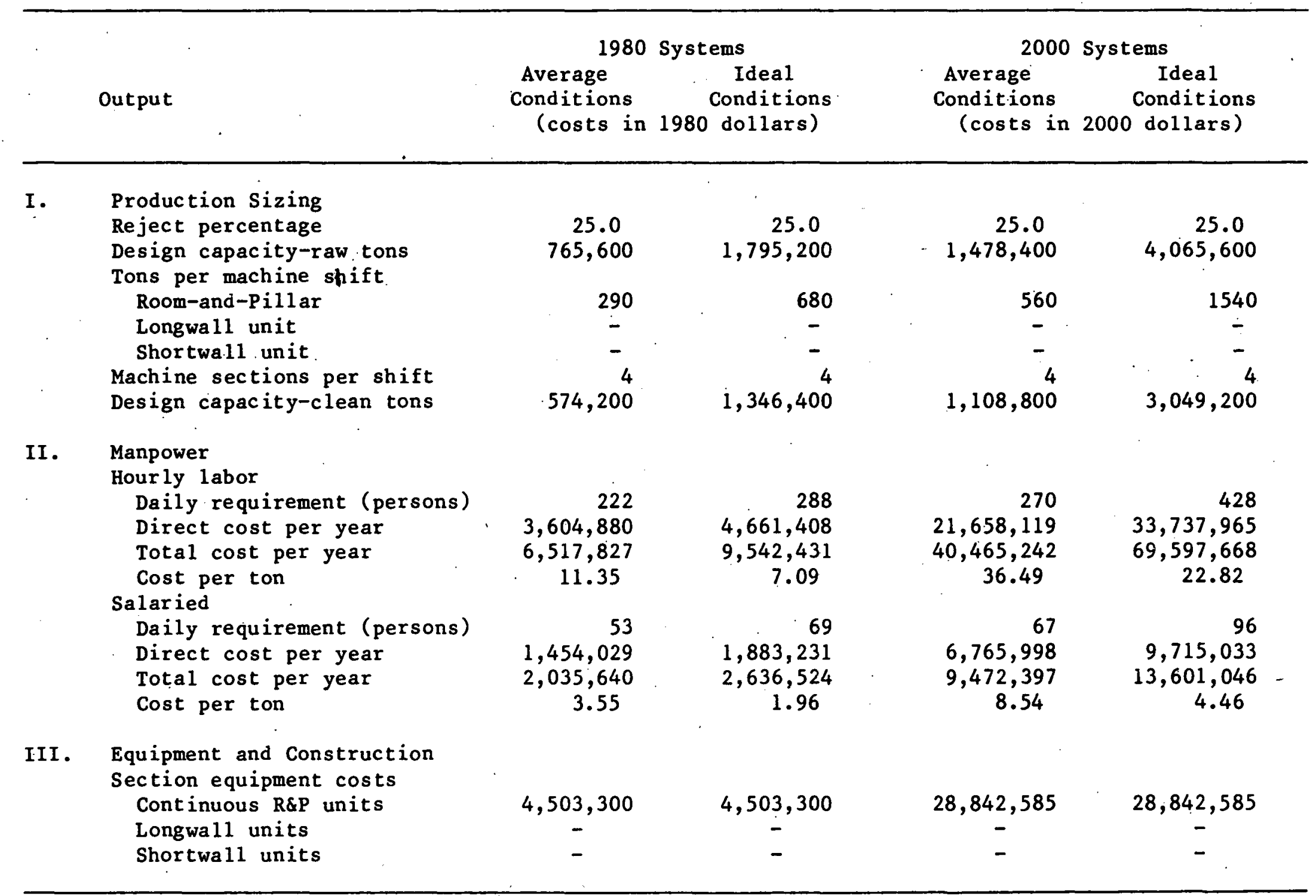




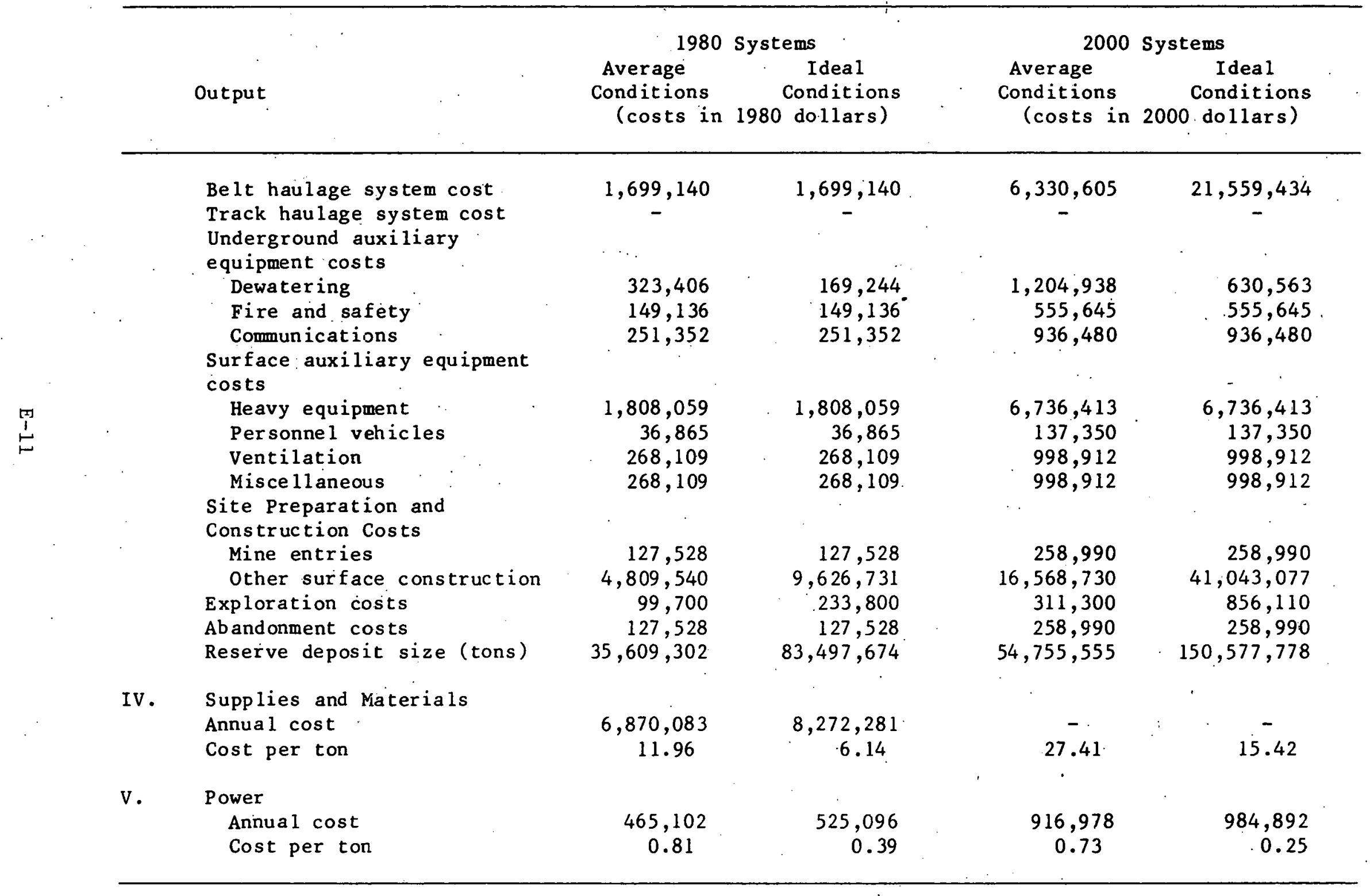


: $\quad$ Average 1980 Systems

Output
Conàitions Conditions

(costs in 1980 dollars)
2000 Systems

Average Ideal
Conditions

(costs in 2000 dollars)

VI. Preproduction Development Direct and indirect costs Development time (years)

Coal production for period (tons)

$\begin{array}{rr}9,998,864 & 5,505,416 \\ 1.36 & 0.56\end{array}$

249,861

$15,911,142$

$16,388,580$

15.0

Interest rate (\%)

Construction and development

time (years)

3.0

$1,605,330$

i, 446,202

$10,573,389$

$3,567,400$

Replacement capital

Additional capital

Total salvage value

Average yearly depreciation

Annual Operating Cost,

$$
\text { Direct }
$$

Indirect

Fixed

Cost per ton

Working capital required

$$
\begin{gathered}
15,888,652 \\
2,076,449 \\
1,764,425 \\
34.36 \\
4,570,831
\end{gathered}
$$

IX. Annual Operating Cost
Working Capital
Annual operating cost

IX. Annual Operating cost
Working Capital
Annual operating cost

$$
\begin{gathered}
26,307,560 \\
0.73
\end{gathered}
$$$$
249,318
$$

255,490

$70,873,509$

$71,749,669$

15.0

2.0

\section{$9,109,899$}

$6,890,939$

$1,928,025$

$12,807,849$

$8,036,320$

$54,934,799$

$20,244,220$

$$
\begin{gathered}
20,976,332 \\
2,895,738 \\
2,352,449 \\
19.48 \\
6,074,123
\end{gathered}
$$

$14,758,791$

0.25

$\cdot 254,037$

$114,851,279$

$114,683,594$

15.0

2.0

\section{$9,104,220$}

$9,798,414$

$70,157,319$

$20,231,600$ 
CONTINUOUS ROOM-AND-PILLAR CASES (Continliation 3)

\begin{tabular}{|c|c|c|c|c|c|}
\hline & Output & $\begin{array}{l}1980 \\
\text { Average } \\
\text { Conaitions } \\
\text { (costs in }\end{array}$ & $\begin{array}{l}\text { Systems } \\
\text { Ideal } \\
\text { Conditions } \\
1980 \text { dollars) }\end{array}$ & $\begin{array}{l}2000 \\
\text { Average. } \\
\text { Conditions } \\
\text { (costs in }\end{array}$ & $\begin{array}{l}\text { Systems } \\
\text { Ideal } \\
\text { Conditions } \\
2000 \text { dollars) }\end{array}$ \\
\hline $\mathrm{X}$ & $\begin{array}{l}\text { Production cost } \\
\text { Federal tax rate (\%) } \\
\text { State and local tax rate }(\%) \\
\text { Total capital, investment } \\
\text { Present worth of capital } \\
\text { investment } \\
\text { Debt/equity ratio } \\
\text { Required net annual cash flow } \\
\text { Annual gross profit } \\
\text { Annual sales revenue } \\
\text { Production cost ( } / \text { ton) } \\
\text { Production cost components } \\
\text { Labor } \\
\text { Supplies } \\
\text { Power } \\
\text { Union } \\
\text { Royalties } \\
\text { Capital related } \\
\text {. }\end{array}$ & $\begin{array}{c}48.0 \\
2.0 \\
29,051,567 \\
23,820,908 \\
0.0 \\
3,805,663 \\
3,145,948 \\
22,875,474 \\
39.84 \\
12.33 \\
11.96 \\
0.81 \\
2.56 \\
0.50 \\
11.67\end{array}$ & $\begin{array}{c}48.0 \\
2.0 \\
38,688,021 \\
31,729,384 \\
0.0 \\
5,069,133 \\
4,188,145 \\
30,412,662 \\
22.59 \\
6.81 \\
6.14 \\
0.39 \\
2.24 \\
0.50 \\
6.51\end{array}$ & $\begin{array}{c}48.0 \\
2.0 \\
138,077,778 \\
110,425,991 \\
0.0 \\
17,641,819 \\
14,334,505 \\
114,860,332 \\
103.59 \\
35.89 \\
27.41 \\
0.83 \\
9.15 \\
1.94 \\
28.38\end{array}$ & $\begin{array}{c}48.0 \\
2.0 \\
196,227,282 \\
. ? \\
170,560,754 \\
0.0 \\
27,249,037 \\
23,267,496 \\
186,054,920 \\
61: 02 \\
\\
19.95 \\
15.42 \\
0.32 \\
7: 33 \\
1.94 \\
16: 05\end{array}$ \\
\hline
\end{tabular}

